



\section{Nordisk kvalitetsmåling i sundhedsvæsenet}




\section{Nordisk kvalitetsmåling i sundhedsvæsenet}

TemaNord 2010:572

(c) Nordisk Ministerråd, København 2010

ISBN 978-92-893-2110-5

Tryk: Kailow Espress ApS

Omslagsfoto: Image Select

Oplag: 1000

Trykt på miljøvenligt papir som opfylder kravene i den nordiske miljøsvanemærkeordning. Publikationen kan bestilles på www.norden.org/order. Flere publikationer på www.norden.org/publikationer

Printed in Denmark

Nordisk Ministerråd

Ved Stranden 18

1061 København K

Telefon (+45) 33960200

Fax (+45) 33960202

\section{Nordisk Råd}

Ved Stranden 18

1061 København K

Telefon (+45) 33960400

Fax (+45) 33111870

www.norden.org

\section{Det nordiske samarbejde}

Det nordiske samarbejde er en af verdens mest omfattende regionale samarbejdsformer. Samarbejdet omfatter Danmark, Finland, Island, Norge og Sverige, samt de selvstyrende områder Færøerne, Grønland og Åland.

Det nordiske samarbejde er både politisk, økonomisk og kulturelt forankret, og er en vigtig medspiller i det europæiske og internationale samarbejde. Det nordiske fællesskab arbejder for et stærkt Norden i et stærkt Europa.

Det nordiske samarbejde ønsker at styrke nordiske og regionale interesser og værdier i en global omverden. Fælles værdier landene imellem er med til at styrke Nordens position som en af verdens mest innovative og konkurrencedygtige regioner. 


\section{Indholdsfortegnelse}

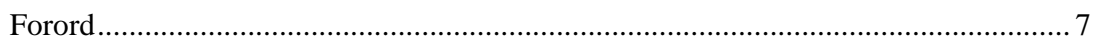

Resumé

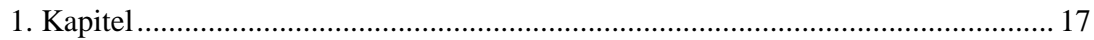

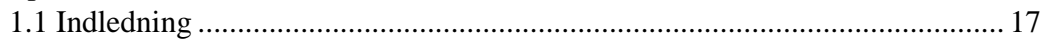

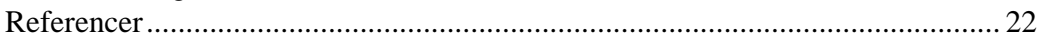

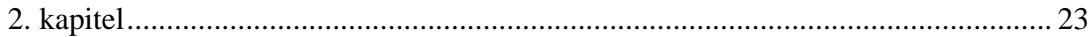

2.1 Generiske og sygdomsspecifikke kvalitetsindikatorer ………………….......... 23

2.2 Valg af prioriterede og potentielle kvalitetsindikatorer .................................... 29

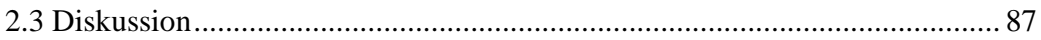

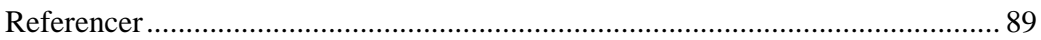

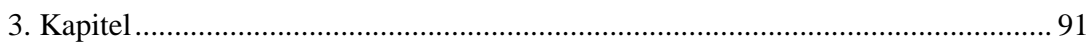

3.1 Kvalitetsindikatorer för mun- och tandhälsovården ……………………….... 91

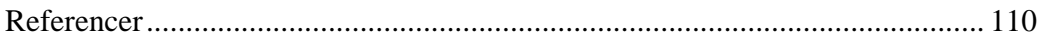

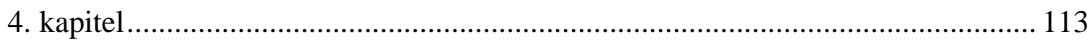

4.1 Kvalitetsindikatorer för patientsäkerhet ………………………………...... 113

4.2 Vårdskador i sluten somatisk vård ............................................................. 117

4.3 Patientsäkerhetskultur .............................................................................. 121

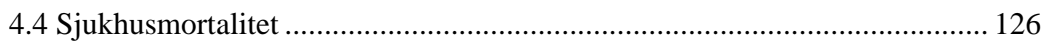

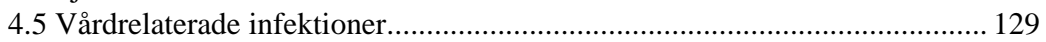

4.6 Överförskrivning av läkemedel hos äldre..................................................... 146

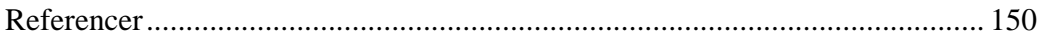

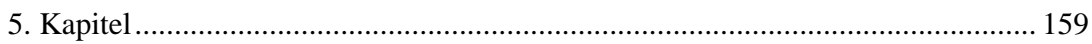

5.1 Nordisk kvalitetsmåling af patienterfaringer i sundhedsvæsenet .................. 159

5.2 Valg av og begrunnelse for prioriterte indikatorer ......................................... 163

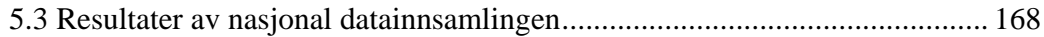

5.4 Valg av og begrunnelse for potensielle indikatorer ....................................... 171

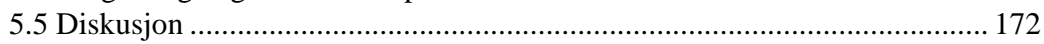

5.6 Perspektiver............................................................................................... 174

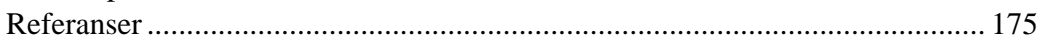

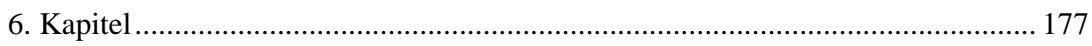

6.1 Konklusioner og anbefalinger ...................................................................... 177 


Summary




\section{Forord}

De nordiske lande har i de sidste år fokuseret på udvikling af de nordiske sundhedssystemer. Målet er at placere Norden som foregangsregion på disse felter og samtidig imødekomme globaliseringsudviklingen på sundhedsområdet. Nordisk Ministerråd på social- og sundhedsområdet drøftede i sommeren 2010 omorganisering af sundhedsvæesenet i de nordiske lande og besluttede at fortsætte samarbejde på dette område.

Kvalitetsudvikling og patientsikkerhed har en central plads i sundhedsvæsenet i de nordiske lande, og der er i landene iværksat vigtige initiativer. I internationalt perspektiv er de nordiske lande således de lande, der er nået længst med formaliseret og systematisk kvalitetsudvikling og patientsikkerhed i sundhedsvæsenet.

I 2007 iværksatte Nordisk Ministerråd fire projekter med formålet at kortlægge, videreudvikle og styrke fællesnordisk kvalitetsmåling og monitorering i relation til specifikke sygdomme og tilstande, mund- og tandpleje, patientsikkerhed, samt patientoplevet kvalitet.

Herudover skulle projektet bidrage til offentliggørelse af data til belysning af kvaliteten af sundhedsvæsenets ydelser samt muliggøre sammenligninger og benchmarking mellem de nordiske lande. Projektets overordnede formål er således at gøre kvaliteten af ydelserne i de nordiske sundhedsvæsener gennemskuelig og gennemsigtig for patienterne, borgerne, politikerne, sundhedspersonale og sundhedsmydighederne på tværs af landegrænserne. 
Der er udvist et stort engagement, og mange eksperter fra de involverede lande har bidraget med viden. Der er identificeret relevante og valide kvalitetsindikatorer for store sygdomsgrupper samt for mund- og tandpleje. På grundlag af dette arbejde er der skabt et potentiale for løbende at offentliggøre data pa tværs af de nordiske lande i fremtiden.

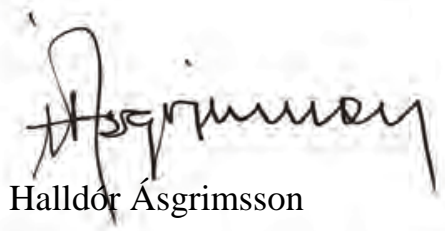

Generalsekretær

Nordisk Ministerråd 


\section{Resumé}

I de nordiske lande er der stort fokus på kvalitetsudvikling og patientsikkerhed, og i de respektive lande er der iværksat velfungerende initiativer til belysning af kvaliteten af sundhedsvæsenets ydelser.

De nordiske lande har enestående muligheder for måling og overvågning af ydelserne, idet alle lande løbende indsamler data i sundhedsregistre.

I forlængelse heraf iværksatte Nordisk Ministerråd i 2007 fire delprojekter, der har til formål at videreudvikle kvalitetsindikatorer med henblik på formidling, sammenligning og benchmarking mellem de nordiske lande.

Det overordnede formål er at give de nordiske borgere, politikere, sundhedspersonale og sundhedsmyndigheder mulighed for at vurdere og sammenligne sundhedsvæsenets ydelser på tværs af de nordiske landegrænser. Et andet formål er ligeledes at identificere områder, hvor de nordiske lande kan lære af hinanden med henblik på at forbedre kvaliteten af sundhedsvæsenets ydelser for dem, det hele drejer sig om, nemlig patienterne.

På baggrund heraf etablerede Nordisk Ministerråd 4 projektgrupper, der i perioden 2007-2010 skulle fokusere på:

- Generiske og sygdomsspecifikke kvalitetsindikatorer

- Kvalitetsindikatorer for mund- og tandpleje

- Patientsikkerhedsindikatorer

- Kvalitetsindikatorer for patientoplevet kvalitet.

I projektperioden har der været et tæt samarbejde med OECD for at sikre synergi til det internationale arbejde med kvalitetsindikatorer. OECDs kvalitetsindikatorer er således inkluderet i det foreliggende arbejde. De fire projektgruppers arbejde er beskrevet nedenfor. 


\section{Generiske og sygdomsspecifikke kvalitetsindikatorer}

Projektgruppen vedrørende generiske og sygdomsspecifikke kvalitetsindikatorer har haft i opdrag at udarbejde, kortlægge og videreudvikle forslag til indikatorer, som kan danne grundlag for registrering og overvågning af kvaliteten af sundhedsvæsenets ydelser i de nordiske lande. De valgte kvalitetsindikatorer er prioriteret i relation til: hyppighed, alvorlighed, variation og økonomi.

Indikatorerne er valgt med henblik på at kunne afspejle såvel den organisatoriske som den sundhedsfaglige kvalitet. Ligeledes er indikatorerne valgt med henblik på at kunne belyse strukturelle forhold, selve patientforløbet (processen) samt resultatet for patienten.

Projektgruppen har valgt at fokusere på følgende områder:

- Kræftsygdomme (brystkræft, lungekræft, livmoderhalskræft, tyk- og endetarmskræft, malignt melanom)

- Hjerte/karsygdomme (blodprop i hjertet, blodprop i hjernen samt hjerneblødning)

- Kroniske sygdomme (diabetes og astma)

- Graviditet og fødsel

- Børn og unge

- Sundhedsfremme og forebyggelse

- Generelle indikatorer, der belyser elementer i enhver patients forløb

- Psykiatri.

Projektgruppen har udvalgt en række indikatorer, hvor det vurderes, at der aktuelt kan indsamles relevante data, som er præsenteret i rapporten.

Herudover har projektgruppen udarbejdet og videreudviklet potentielle indikatorer, som vurderes at kunne indgå i sammenligninger og benchmarking mellem de nordiske lande i de kommende år.

Rapporten viser, at det på en lang række områder er muligt at tilvejebringe data, som muliggør sammenligning på tværs af de nordiske lande, mens der på andre områder kun i beskedent omfang findes data. Dette betyder, at der på en række områder er fortsat behov at videreudvikle fællesnordiske kvalitetsindikatorer.

Dette gælder eksempelvis i relation til psykiatri, hvor der er behov for at udvikle kvalitetsindikatorer, der belyser patienternes forløb i sundhedsvæsenet, samt sundhedsfremme og forebyggelse, hvor der er behov for flere data vedrørende levevilkår og levestandard. 
På de områder, hvor der findes robuste data, anbefales det, at data løbende offentliggøres i NOMESCO-regi.

\section{Kvalitetsindikatorer för mun- och tandhälsovården}

De nordiska länderna inser behovet av kvalitetsindikatorer för tandhälsovården, för att man ska kunna följa upp tandvårdskvaliteten och jämföra prestationerna mellan de nordiska länderna. Projektet föranleddes av bristen på gemensamma kvalitetsindikatorer i Norden, även om kvalitetsarbete i samband med tandvården har utförts i respektive land.

Av arbetsgruppens mandat framgick, att projektet skulle förbereda ett förslag och ta fram gemensamma nordiska kvalitetsindikatorer för tandhälsovården. Arbetet skulle kopplas till OECD och föregående EGOHID (European Global Oral Health Indicators Development Project) projekt. Arbetsgruppens mandatperiod fastställdes till tre år, och projektet startade 2007. Danmark, Färöarna, Finland, Island, Norge och Sverige deltog i projektet. Finland fungerade som projektkoordinator.

Projektet inleddes med en genomgång av befintliga indikatorer för tandhälsa i de nordiska länderna och filosofierna bakom dem. Indikatorerna valdes utifrån ECHI-rekommendationerna (European Community Health Indicators), OECD-rekommendationerna, EGOHID-arbetet, och utifrån de nordiska ländernas specifika intressen.

Indikatorerna delades in i fyra grupper: strukturindikatorer, processindikatorer, resultatindikatorer och potentiella kvalitetsindikatorer - indikatorer, som ska tas fram.

Arbetsgruppen enades om 4 strukturindikatorer: 1 . antal invånare per legitimerad tandvårdspersonal under pensionsåldern, 2. antal invånare per yrkesaktiv tandvårdspersonal under pensionsåldern, 3 . antal tandläkare under pensionsåldern per tandvårdspersonal, 4. tandvårdskostnader per invånare, 3 processindikatorer: 1. andel (\%) av befolkningen som har besökt tandvården inom ett år, 2. tandborstningsfrekvens (mer än en gång per dag), 3. konsumtion av sockerhaltiga läskedrycker, 5 resultatindikatorer: 1 . andel kariesfria av undersökta barn och ungdomar, 2. medelvärdet för DMFT (Decayed, Missing and Filled Teeth) hos undersökta barn och ungdomar, 3. SiC-index (Significant Caries Index), 4. andel (\%) tandlösa 65-74-åringar i befolkningen, 5. andel (\%) 65-74åringar, som har minst 20 kvarvarande tänder i munnen och 3 potentiella kvalitetsindikatorer: 1 . andel av befolkningen, som besöker tandvården regelbundet, 2. självupplevd tandhälsa (munhälsa), 3. självupplevd tuggförmåga. Det krav 
som ställdes på indikatorerna för att de skulle tas med var, att det skulle finnas data om dem i minst tre av de nordiska länderna.

Bristen på data för några av resultatindikatorerna illustrerar svårigheten att få fram enhetliga och aktuella kvalitetsdata om tandhälsovården i de nordiska länderna. Mycket arbete har lagts ned på att definiera indikatorerna, och därför kan större delen insamlade data användas för jämförelser och benchmarking, men det krävs ändå ytterligare arbete för att utveckla relevanta kvalitetsindikatorer.

Arbetsgruppen har betonat vikten av, att alla nordiska länder arbetar för att få fram data om de överenskomna indikatorerna utifrån samma metoder t.ex. identiska definitioner och jämförbara åldersgrupper. I framtiden krävs fler kvalitetsindikatorer för tandhälsovården, och arbetsgruppen var enig att arbetet ska fortsätta.

\section{Kvalitetsindikatorer för patientsäkerhet}

Under de senaste tio åren har begreppet patientsäkerhet fått stor uppmärksamhet. Resultat från ett stort antal studier i flera olika länder pekar samstämmigt på, att många patienter skadas i onödan i vården. Det kan röra sig om missade eller för sent ställda diagnoser, felaktiga ingrepp, felaktig läkemedelshantering och bristande hygien som medfört svåra infektioner.

Studierna har bidragit till att uppmärksamma risker och brister i vården och påskyndat utvecklingen mot en högre patientsäkerhet. Förutom att minska det lidande, som dessa skador orsakar patienter och närstående, lönar det sig även ur ett ekonomiskt perspektiv att förbättra patientsäkerheten. Skador orsakade av hälso- och sjukvården orsakar extra vårdtid på sjukhus, vilket innebär både ökade kostnader och sämre tillgänglighet. Dessutom uppstår betydande kostnader för samhället.

Hälso- och sjukvård är en komplex högriskverksamhet, och det krävs insatser på alla olika nivåer för att öka patientsäkerheten. Att uppmärksamma och hantera risker bör bli en naturlig del i vårdens arbetssätt. För detta krävs en säkerhetskultur som tillåter att personalen öppet rapporterar och diskuterar de misstag som inträffat så att åtgärder sätts in för att förhindra liknande misstag. Det ska vara lätt att göra rätt och svårt att göra fel. Hög patientsäkerhet förutsätter också att undersökningar, behandlingar och omvårdnad utgår från vetenskap och beprövad erfarenhet.

En hög patientsäkerhet är en förutsättning för att upprätthålla medborgarnas förtroende för hälso- och sjukvården. Det är därför angeläget att utveckla 
indikatorer som belyser graden av patientsäkerhet i vården. Forskningen och kunskapsuppbyggnaden kring området patientsäkerhet har nyligen startat, och området saknar därför fungerande strukturer och register för datainsamling samt den kunskap och vetenskapliga dokumentation som behövs för att ta fram väl underbyggda indikatorer. Arbetet med att utveckla patientsäkerhetsindikatorer har påbörjats inom OECD och EU och det nordiska samarbetet kan här ge ett värdefullt bidrag.

Nordisk kvalitetsmåling af patienterfaringer i sundhedsvcesenet

Pasienters erfaringer og tilfredshet er en viktig del av kvaliteten på helsetjenesten. En av arbeidsgruppene i det nordiske indikatorsamarbeidet har derfor arbeidet med indikatorer for pasientopplevd kvalitet.

Oppdraget til arbeidsgruppen var å framskaffe indikatorer og måleinstrument for å gjenspeile pasientopplevd kvalitet. Mandatet var å foreslå 6-12 potensielle indikatorer som kan danne grunnlaget for registrering og overvåking av feltet i forhold til sammenligning av data på tvers av de nordiske landene.

Nasjonale brukerundersøkelser i de nordiske landene er noe forskjellige. Det ble tidlig klart at ingen av landene ønsket å erstatte eksisterende nasjonale pasienterfaringsundersøkelser. Dermed la gruppen til grunn at de nordiske indikatorene skulle integreres som supplement i eksisterende undersøkelser i det enkelte land. Gruppen ble enig om 8 pasienterfaringsspørsmål for voksne døgnsomatiske pasienter, hvorav 6 handler om relasjon til helsepersonell, ett om feilbehandling og ett om generell tilfredshet.

Gruppen laget standard metoder for oversettelse, kognitive intervjuer og pilotundersøkelse av spørsmålene. Oversettelsene, kognitive intervjuer og pilottesting viser at instrumentet fungerer godt. De 8 spørsmålene har navnet NORPEQ (NORdic Patient Experiences Questionnaire).

Norge inkluderte NORPEQ i en nasjonal undersøkelse i 2006. Målet var at de andre landene skulle inkludere NORPEQ i kommende nasjonale undersøkelser, etter oversettelse, kognitive intervjuer og pilotundersøkelse i det enkelte land. Det viste seg i praksis å være flere barrierer forbundet med å inkludere NORPEQ i andre nasjonale undersøkelser, både når det gjelder finansiering, nasjonal infrastruktur og lovverk.

Arbeidsgruppen peker på viktigheten av at inkludering av NORPEQ i nasjonale pasienterfaringsundersøkelser forankres gjennom eksplisitte helsepolitiske beslutninger i det enkelte land, og at dette følges opp i årene som kommer. 
NORPEQ er tilpasset voksne døgnsomatiske pasienter, som er en viktig men begrenset pasientgruppe når vi ser på spesialist- og primærhelsetjenesten samlet. Nasjonalt kunnskapssenter for helsetjenesten og sekretariatet i Norge har utviklet og testet 10 generiske kjernespørsmål som kan brukes på tvers av 9 pasientgrupper inkludert psykiatri og poliklinisk somatikk. Dette instrumentet er nå tilgjengelig for de andre nordiske landene, og kan utgjøre potensielle nordiske indikatorer på sikt.

Indikatorer basert på OECD responsiveness prosjektet er også potensielle indikatorer i det nordiske prosjektet framover i tid.

\section{Perspektiver}

Denne rapport dokumenterer, at der er et stort potentiale for måling og monitorering af sundhedsvæsenets ydelser i de nordiske lande, og det kan konkluderes, at det er muligt at identificere relevante kvalitetsindikatorer på tværs af landene. Der er imidlertid behov for en betydelig indsats for at sikre datakvaliteten, herunder validitet og tilvejebringelse af data på en række områder.

En række af de resultater, der er tilgængelige, kan således næppe anvendes til retvisende sammenligninger og benchmarking, men snarere til at stille spørgsmål om, hvorvidt der vitterlig eksisterer reelle forskelle i kvaliteten af ydelser. Der er derfor behov for en betydelig indsats med henblik på at sikre valide, tidstro data med henblik på retvisende sammenligning og benchmarking mellem de nordiske lande. Ligeledes er der behov for en dynamisk udvikling af potentielle kvalitetsindikatorer.

Det fremgår ligeledes, at det på vigtige områder ikke er muligt at tilvejebringe data, som gør det muligt at foretage sammenligninger mellem de nordiske lande. Det har således ikke været muligt at tilvejebringe data til belysning af patientsikkerhed i de nordiske lande. Internationalt er arbejdet med at udvikle kvalitetsindikatorer på dette område netop påbegyndt, og det forventes, at de nordiske lande kan bidrage til denne udvikling.

I relation til psykiatri er der behov for i øget omfang at udvikle kvalitetsindikatorer, der belyser patienternes forløb i sundhedsvæsenet. Internationalt er dette område svagt belyst. Det vurderes, at de nordiske lande kan bidrage til, at der udvikles kvalificerede kvalitetsindikatorer både på dette område, samt for sundhedsfremme og forebyggelse.

Arbejdet med kvalitetsindikatorer for mund- og tandsundhed illustrerer, at de nordiske lande er ganske langt på dette område. Det påpeges imidlertid, at der er behov for videreudvikling af kvalitetsindikatorer på dette område. 
Arbejdet i Nordisk Ministerråds projektgrupper vedr. kvalitetsmåling illustrerer det moderne sundhedsvæsens begrænsede muligheder for at dokumentere kvaliteten af sundhedsvæsenets ydelser på vigtige områder.

De nordiske lande har imidlertid som anført unikke muligheder for at udvikle dette område. Det foreliggende projektarbejde betragtes som et solidt grundlag herfor. I forlængelse heraf anbefales det:

- at der på områder, hvor der findes robuste data i relation til de valgte kvalitetsindikatorer, løbende offentliggøres kvalitetsdata i NOMESCO’s regi med henblik på at give borgere, politikere, sundhedspersonale og myndigheder indblik i kvaliteten af sundhedsvæsenets ydelser på tværs af de nordiske landegrænser

- at der i Nordisk Ministerråds regi etableres en arbejdsgruppe, der videreudvikler fællesnordiske kvalitetsindikatorer for psykiatri, samt sundhedsfremme og forebyggelse

- at der etableres en arbejdsgruppe i Nordisk Ministerråds regi med henblik på at videreudvikle det fællesnordiske samarbejde om patientsikkerhed

- at der i Nordisk Ministerråds regi etableres en arbejdsgruppe mhp. at videreudvikle kvalitetsindikatorer for mund- og tandsundhed. 



\section{Kapitel}

\subsection{Indledning}

Kvalitetsudvikling og patientsikkerhed i sundhedsvæsenet prioriteres højt i de nordiske lande (Danmark, Finland, Færøerne, Grønland, Island, Norge og Sverige). Landene har særlige forudsætninger for dokumentation af kvaliteten af sundhedsvæsenets ydelser, idet der i de nordiske lande løbende foretages registreringer i velfungerende sundhedsregistre. Der er samtidig muligheder for at udnytte og kombinere forskellige registre, således at der kan tilvejebringes valide data til belysning af kvaliteten af sundhedsvæsenets ydelser.

På dette grundlag iværksatte Nordisk Ministerråd i foråret 2007 fire projekter, der havde til formål at videreudvikle kvalitetsindikatorer på grundlag af ensartede målemetoder. Indikatorernes formål var at belyse kvaliteten af sundhedsvæsenets ydelser mellem de nordiske lande gennem sammenligning, benchmarking og formidling af resultater.

Projektets grundlæggende ide har ligeledes været, at projektets resultater skal kunne indebære mulighed for, at de nordiske lande kan lære af hinanden samt give anledning til inspiration landene imellem.

Det overordnede mål med projektgruppernes virksomhed er at give de nordiske borgere, patienter, politikere, sundhedspersonale og sundhedsmyndigheder mulighed for at vurdere og sammenligne kvaliteten af sundhedsvæsenets ydelser på tværs af de nordiske landegrænser og derved medvirke til afskaffelse af grænsehindringer mellem de nordiske lande.

Projekterne er en fortsættelse af to tidligere projekter i Nordisk Ministerråds regi. De tidligere projekter blev afsluttet med to rapporter:

- NHV-Rapport 2003:1: Kvalitetsmåling i Sundhedsvæsenet. Rapport fra Nordisk Ministerråds Arbejdsgruppe

- TemaNord 2007:519: Kvalitetsmåling i sundhedsvæsenet i Norden. 
På grundlag af TemaNord-rapporten blev det anbefalet at

- der blev etableret en arbejdsgruppe i Nordisk Ministerråds regi med formålet at konsolidere og videreudvikle fællesnordiske kvalitetsindikatorer, herunder sikre ensartet dataindsamling og offentliggørelse af resultater vedrørende kvaliteten af sundhedsvæsenets ydelser i de nordiske lande, samt i forlængelse heraf, sikre fællesnordisk koordination med arbejdet med kvalitetsindikatorer i OECD

- der blev etableret en arbejdsgruppe i Nordisk Ministerråds regi med henblik på at styrke det fællesnordiske samarbejde om patientsikkerhed

- der blev iværksat bestræbelser på at belyse kvaliteten af sundhedsvæsenets ydelser gennem løbende offentliggørelse i NOMESCO’s publikationer

- der blev etableret en arbejdsgruppe i Nordisk Ministerråds regi, som havde til formål at udvikle og afprøve et instrument til belysning og benchmarking af den patientoplevede kvalitet.

På baggrund af rapportens anbefalinger om en videreudvikling af fælles nordiske kvalitetsindikatorer etablerede Nordisk Ministerråd en styregruppe og fire delprojekter, som skulle fokusere på:

- Fællesnordiske generiske og sygdomsspecifikke kvalitetsindikatorer

- Fællesnordiske kvalitetsindikatorer for mund- og tandsundhed

- Fællesnordiske patientsikkerhedsindikatorer

- Fællesnordiske kvalitetsindikatorer for patientoplevet kvalitet.

\subsubsection{Mandat}

Styregruppens mandatperiode blev fastsat til 3 år (fra foråret 2007 til efteråret 2010).

Styregruppens overordnede formål var at fungere som forbindelsesled og koordinator mellem de nordiske nationale sundhedsmyndigheder og Nordisk Ministerråd samt de konkrete fællesnordiske projekter vedrørende kvalitetsmåling i sundhedsvæsenet.

Styregruppen bestod af 1-2 repræsentanter fra hvert af de nordiske lande, som skulle have kompetence og erfaring med kvalitetsmålingsarbejdet såvel 
nationalt som internationalt, samt være forankret i de respektive nationale sundhedsmyndigheder.

Repræsentanterne skulle endvidere have indgående kendskab til det hidtidige fællesnordiske arbejde vedrørende kvalitetsmåling i sundhedsvæsenet.

Styregruppens samlede mandat og repræsentanter kan ses i bilag 1 og 2 .

Hvert projekts kommissorium, virksomhed og resultater er beskrevet i særskilte kapitler:

2. Kapitel: Fællesnordiske generiske og sygdomsspecifikke kvalitetsindikatorer

3. Kapitel: Fællesnordiske kvalitetsindikatorer for mund - og tandsundhed

4. Kapitel: Fællesnordiske patientsikkerhedsindikatorer

5. Kapitel: Fællesnordiske kvalitetsindikatorer for patientoplevet kvalitet.

\subsubsection{Generelt om kvalitetsindikatorer}

En kvalitetsindikator er en målbar variabel, som kan anvendes til at overvåge og evaluere kvaliteten af sundhedsvæsenets ydelser $(1,2)$.

Kvalitetsindikatorer kan anvendes til at monitorere sundhedsvæsenets struktur og organisation, strategisk vigtige aspekter af patientforløbet, samt resultatet af sundhedsvæsenets ydelser for patienten dvs. helbredsgevinsten. Indikatorer kan sjældent stå alene, men kan anvendes som led i en samlet faglig analyse, vurdering og fortolkning.

Man kan skelne mellem strukturindikatorer, procesindikatorer og resultatindikatorer (3):

Strukturindikatorer beskriver sundhedsvæsenets rammer og ressourcer, herunder sundhedsprofessionernes kompetencer og tilgængeligheden til udstyr, teknologi og faciliteter. Indikatorerne beskriver med andre ord forudsætningerne og rammerne for forebyggelse, diagnostik, behandling, pleje og rehabilitering.

Procesindikatorer angiver konkrete aktiviteter i patientforløbet og giver dermed et billede af i hvilket omfang, sundhedspersonalet har udført bestemte procedurer, eksempelvis forebyggelse, diagnostik, behandling, pleje og rehabilitering eller kommunikation, i patientforløbet. Procesindikatorer udvikles på grundlag af referenceprogrammer eller kliniske retningslinjer, såfremt de 
findes. Procesindikatorerne udtrykker, om patienterne har modtaget de ydelser, som de bør ifølge referenceprogrammer og kliniske retningslinjer.

Resultatindikatorer belyser patientens helbredsgevinst i form af overlevelse, symptomatologiske og laboratoriemæssige karakteristika, patientens fysiske formåen eller psykiske reaktioner på sygdomme og tilfredsheden med behandlingen (4).

\subsubsection{Forståelsesramme}

I Nordisk Ministerråds projektgrupper er OECDs forståelsesramme for monitorering af kvaliteten af sundhedsvæsenets ydelser adapteret, og en tilpasning af modellen til det nordiske projekt er illustreret i figur 1 (5).

Figur 1. Forståelsesramme for monitorering af sundhedsvæsenets ydelser på grundlag af kvalitetsindikatorer

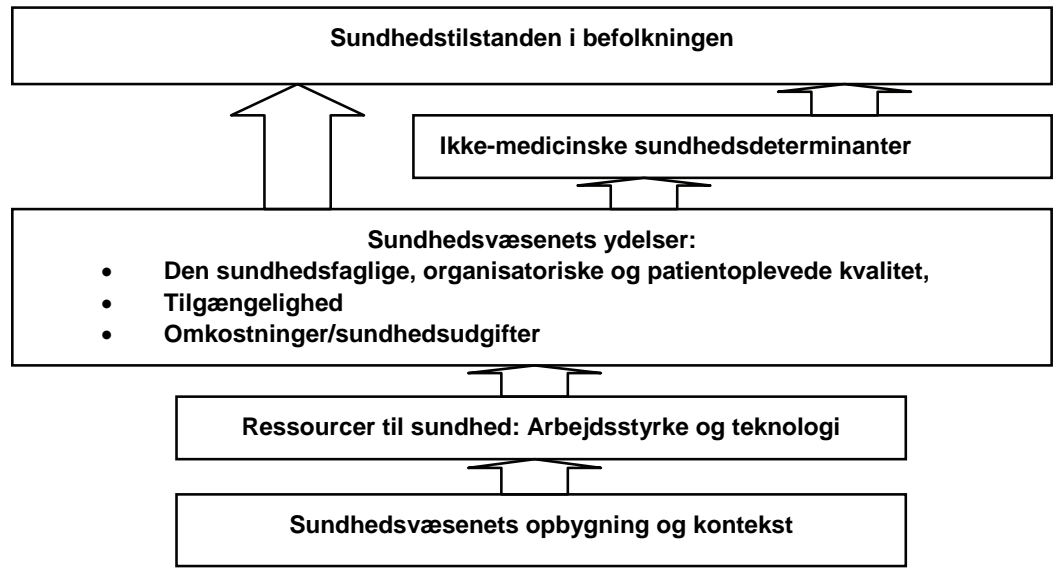

Kilde. Adaptation of the OECD (2006), Conceptual Framework for the OECD Health Care Quality Indicators Project, OECD Health Working Paper, No. 23, OECD Publishing, Paris. Health at a Glance 2009: OECD Indicators @ OECD 2009

Det fremgår af forståelsesrammen, at sundhedsvæsenets overordnede mål er at forbedre befolkningens sundhedstilstand, som afhænger af en række ikkemedicinske determinanter, herunder det sociale, økonomiske og fysiske miljø, som befolkningen lever i, samt befolkningens livsstil og sundhedsadfærd.

Sundhedsvæsenet bidrager ligeledes til befolkningens sundhedstilstand. Dette bidrag afhænger blandt andet af kvaliteten af sundhedsvæsenets ydelser samt af tilgængeligheden til ydelserne. 
Kvaliteten af sundhedsvæsenets ydelser omfatter den sundhedsfaglige kvalitet i relation til forebyggelse, diagnostik, behandling, pleje og rehabilitering samt den organisatoriske kvalitet, dvs. kontinuitet og koordination af sundhedsvæsenets ydelser. Endelig omfatter kvaliteten af sundhedsvæsenets ydelser også den patientoplevede kvalitet, dvs. brugerens oplevelse af udførelsen af sundhedsvæsenets ydelser, samt resultatet heraf $(6,7,8)$.

Endvidere afhænger sundhedsvæsenets præstationer af de tilgængelige ressourcer i form af kvalificeret sundhedspersonale samt tilgængelighed til medicinsk teknologi og udstyr.

Endelig spiller en række faktorer en rolle for sundhedsvæsenets præstationer, herunder den demografiske, økonomiske og sociale kontekst samt sundhedsvæsenets opbygning.

Som det fremgår af forståelsesrammen (figur 1), er der en kompleks række af faktorer, der skal inddrages, når man skal fortolke kvaliteten af sundhedsvæsenets ydelser på grundlag af kvalitetsindikatorer. Fortolkningen af kvalitetsdata bliver endnu mere kompleks, såfremt dette sker på internationalt niveau, hvor en lang række faktorer i relation til forståelsesrammen kan variere. Dette indebærer, at konkrete indikatorresultater på internationalt niveau skal fortolkes med stor omhyggelighed og forsigtighed.

Nordisk Ministerråds samlede projekt om kvalitetsmåling fokuserer især på monitorering af kvaliteten af sundhedsvæsenets ydelser samt helbredseffekten heraf for befolkningen. Dette er hovedfokus i kapitel 2, 3, 4 og 5.

Som det fremgår kapitel 2 beskrives ikke-medicinske determinanter med betydning for befolkningens sundhedstilstand i relation til forebyggelse og sundhedsfremme samt i relation til børn og unge.

I kapitel 3, beskrives de nordiske befolkningers sundhedstilstand med hensyn til mund- og tandsundhed.

\subsubsection{Samarbejde med OECD om kvalitetsindikatorer}

I kommissorierne for Nordisk Ministerråds projektgrupper har det været intentionen, at udvikling af kvalitetsindikatorer skulle koordineres med OECDs Health Care Quality Indicator Project. Dette indebærer, at OECD-indikatorerne indgår som en obligatorisk del af de indikatorsæt, der er udviklet af Nordisk Ministerråds projektgrupper (5).

I hele projektperioden har der været et tæt, positivt og konstruktivt samarbejde mellem Nordisk Ministerråds projektgruppe og OECD. Dette samarbej- 
de har betydet løbende kontakt samt gensidig mødeaktivitet. Desuden har projektgrupperne haft kontakt med National Health Service NHS i England, samt andre organisationer i en række lande, der ønsker at have samarbejde om indikatorudvikling fremover.

\section{Referencer}

(1) Mainz J. Defining and classifying clinical indicators for quality improvement. International journal for quality in healthcare 2003; 15: 6: 523-530.

(2) Mainz J. Developing Evidence-based clinical indicators: A state of the art methods primer. International journal for quality for healthcare 2003; 15. supplement 1: I 5-I 11.

(3) Mainz J. Quality Indicators. Essential for quality improvement. International Journal for Quality and healthcare 2004; 16: Supplement 1: I1 - I2

(4) Rubin HR. Provonost P. Diette Gb. The advantages and disadvantages of process-based measures off healthcare quality. International Journal for Quality and healthcare 2001; 13: 469 - 474.

(5) Adaptation of the OECD (2006) Conceptual Framework for the OECD
Health Care Quality Indicators Project, OECD Health Working Paper, No. 23, OECD Publishing, Paris. Health at a Glance 2009: OECD Indicators (C) OECD 2009

(6) Rubin HR. Provonost P. Diette Gb. From a process of care to a measure: The development and testing off a quality indicator. International Journal for Quality and healthcare 2001; 13: 489-496.

(7) McGlynn EA. The outcomes utility index: will outcomes data tell us what we want to know? International Journal for Quality and healthcare 1998; 10: 485-490.

(8) McGlynn EA. Asch SM. Developing a clinic performance measure. AM J Paed MED. 1998; 14: 14-21. 


\section{2. kapitel}

\subsection{Generiske og sygdomsspecifikke kvalitetsindikatorer}

\subsubsection{Kommissorium for projektgruppens virksomhed}

Projektgruppen vedrørende generiske og sygdomsspecifikke kvalitetsindikatorer skulle udarbejde forslag til indikatorer, som kan danne grundlag for registrering og overvågning af kvaliteten af sundhedsvæsenets ydelser i de nordiske lande.

Til belysning af kvaliteten af sundhedsvæsenets ydelser kunne indgå følgende prioriteringskriterier: Volumen, alvorlighed, variation og økonomi.

Valg af indikatorer skulle afspejle den sundhedsfaglige og den organisatoriske kvalitet i relation til struktur, proces og resultat.

Projektgruppen blev etableret oktober 2007 og skulle sammensættes således, at hvert land var sikret orientering fra OECD-møder, samt let adgang til dialog med OECD. Herudover kunne der indkaldes ad hoc eksperter ved behov til gruppens møder.

\subsubsection{Sammensœtning og reprcesentation i projektgruppen}

For at kunne dække områderne i kommissoriet tilstrækkeligt bredt, skulle gruppen bestå af 1-2 personer fra hvert land. Repræsentanterne skulle have godt kendskab til de i kommissoriet nævnte fokusområder.

Projektlederen skulle besidde kompetence inden for kvalitetsmålingsområdet på højt internationalt niveau, have national og international erfaring med udvikling af kvalitetsindikatorer, have erfaring med kvalitetsmåling, implementering af indikatorer i sundhedsvæsenet, formidling af indikatorer, samt 
have et bredt netværk i relevante internationale miljøer, herunder i EU-, WHO- og OECD-regi.

Projektgruppen blev sammensat af 1-3 repræsentanter fra Danmark, Finland, Færøerne, Grønland, Island, Norge og Sverige. Hvert land forestod selv udpegningen af repræsentanterne, som skulle dække de faglige områder, som arbejdsgruppen skulle beskæftige sig med.

Formandskabet og sekretariatsfunktionen er i projektperioden blevet varetaget af Sundhedsstyrelsen, Danmark. Projektgruppen refererede til styregruppen.

Nedenfor ses en oversigt over repræsentanterne i den nordiske projektgruppe, samt sekretariat:

Danmark

- Jan Mainz, professor, ledende overlæge, Ph.D, Sundhedsstyrelsen, formand og OECD-repræsentant

- Paul Bartels, cheflæge, leder af Det Nationale Indikatorprojekt, NIP udpeget af Dansk Medicinsk Selskab Sekretariat:

- Jytte Burgaard, projektkoordinator, Sundhedsstyrelsen

- Mette Thorup Eriksen, akademisk medarbejder, Sundhedsstyrelsen, deltager fra marts 2008 til marts 2009

- Anne-Marie Hansen, fuldmægtig, Det Nationale Indikatorprojekt, deltager fra april 2010 til august 2001 Observatør:

- Birgit Villadsen, ledende oversygeplejerske, Bispebjerg Hospital, udpeget af Dasys

Finland

- Risto Pomoell, medicinalrådet, Social- och hälsovårdsministeriet, deltager indtil december 2007

- Kaj Rönnberg, övertandläkare, Esbo social- och hälsovård, deltager indtil december 2007

- Päivi Hämäläinen, udviklingschef, Stakes/THL Institutet för hälsa och välfärd, deltager fra januar 2008, OECD-repræsentant

- Sari Palojoki, utvecklingschef, Stakes/THL Institutet för hälsa och välfärd, deltager fra september 2008 
Færøerne

- Høgni Debes Joensen, landslæge, Social- og Sundhedsministeriet

Grønland

- Karna Jokumsen, Sundhedsfaglig konsulent, Departementet for Familie og Sundhed, deltager indtil januar 2008

- Marianne Arnfjord, afdelingschef, Direktoratet for Sundhed, deltager fra januar 2008 til maj 2008

- Thomas Stensgaard, læge, Nuuk Sundhedsdistrikt, deltager fra december 2008 til oktober 2009

- Birgit Niclasen, lægefaglig konsulent, Departementet for Sundhed, deltager fra oktober 2009

Island

- Anna Björg Aradóttir, chefsygeplejerske, Sundhedsstyrelsen

- Valgerður Gunnarsdóttir, specialist, Direktorate of Health and Health Service, deltager til oktober 2008

Norge

- Målfrid Monge, seniorrådgiver, Sosial- og helsedirektoratet

- Geir Joner, seksjonsleder, professor, Nasjonalt kunnskapssenter i helsevæsenet, OECD-repræsentant

- Marit Kise, seniorrådgiver, Sosial- og Helsedirektoratet, OECDrepræsentant

- Jon Helgland,SSeniorrådgiver, Nasjonalt kunnskapssenter for helsetjenesten

Sverige

- Max Köster, statistiker, Socialstyrelsen, OECD-repræsentant

- Marie Lawrence, projektleder, Socialstyrelsen, OECD-repræsentant

\subsubsection{Introduktion}

Projektgruppen vedr. generiske og sygdomsspecifikke kvalitetsindikatorer skulle i mandatperioden udarbejde forslag til indikatorer, som kunne danne grundlag for registrering og monitorering af kvaliteten af sundhedsvæsenets ydelser i de nordiske lande. Samtlige prioriterede og potentielle indikatorer i 
Kvalitetsmåling i sundhedvæsenet i Norden, TemaNord 2007:519, samt relevante OECD-indikatorer, skulle indgå i arbejdet og gennemgås i løbet af arbejdsprocessen bl.a. med henblik på stillingtagen til, om de efterfølgende skulle indgå i det endelige indikatorsæt.

Projektgruppen har årligt afholdt 4 møder af hver 2 dages varighed. I arbejdet indgik indikatormateriale fra både de nordiske lande og fra OECD samt fra internationale indikatorprojekter og databaser.

På grundlag af dette materiale foretog projektgruppen prioritering og valg af dels overordnede temaer og dels sundhedsfaglige indikatorer i forhold til strukturer, processer og resultater med størst vægt på resultatindikatorer.

Det har i projektgruppens arbejde været et grundlæggende princip, at de respektive repræsentanter for de nordiske lande skulle bidrage til projektgruppens prioriteringer på grundlag af fastlagt mandat i de respektive lande.

I mandatperioden er der løbende afrapporteret til styregruppen dels ved møder og dels gennem årlige statusrapporter. Til alle møderne er faglige eksperter desuden inviteret til at bidrage med viden og rådgivning om de indikatorområder projektgruppen havde under bearbejdning.

\subsubsection{Valg af fokusområder for udvikling af kvalitetsindikatorer}

Projektgruppen besluttede på de indledende møder, hvilke overordnede temaområder, der skulle fokuseres på. Med mandat fra de enkelte lande besluttedes det, at der skulle udvikles kvalitetsindikatorer i relation til følgende temaer:

- Kræftsygdomme

- Hjerte/karsygdomme

- Diabetes og astma

- Graviditet og fødsel

- Børn og unge

- Sundhedsfremme og forebyggelse

- Generelle indikatorer

- Psykiatri.

Det besluttedes ligeledes, at temaet Primær Sundhedstjeneste i videst mulig omfang skulle indgå i hvert af ovenstående temaer i stedet for at være et selvstændigt tema. Det måtte imidlertid konstateres i projektforløbet, at det ikke har været muligt at tilvejebringe data på området i dette projekt. 
Psykiatri og psykiatri blev ikke inddraget i første omgang som tema, da OECD havde nedsat en projektgruppe, der varetager dette område. I forlængelse af OECDs valg af kvalitetsindikatorer for Psykiatri blev det besluttet at inddrage psykiatri som fokusområde for at supplere OECDs arbejde på dette område.

\subsubsection{Model for prcesentation af kvalitetsindikatorer}

Med henblik på at belyse kvaliteten af sundhedsvæsenets ydelser i relation til de valgte temaområder på en nuanceret måde, udarbejdede projektgruppen en generisk model som grundlag for præsentation af indikatorerne indenfor hvert tema. Modellens opbygning fremgår af figur 2.

\section{Figur 2. Generisk model for kvalitetsindikatorer}

Basisindikatorer

- Incidens

- Prævalens

- Mortalitet

Kvalitetsindikatorer

- Strukturindikatorer

a) Eksisterer der nationalt klinisk kvalitetsregister på området?

b) Eksisterer der kliniske retningslinier (clinical practice guidelines) på området?

- Procesindikatorer

a) Screening

b) Ventetid på diagnostik og behandling

- Intermediære resultatindikatorer

- Resultatindikatorer
a) Letalitet
b) Overlevelse
c) Reoperationer
d) Recidiv
e) Komplikationer
f) Livskvalitet
g) Patienttilfredshed

Som det fremgår, indgår der i modellen såvel basisindikatorer som kvalitetsindikatorer. 
Basisindikatorerne belyser hyppigheden af en given sygdom (prævalensen), samt hastigheden for sygdommens udvikling (incidensen). Hertil kommer mortaliteten, dvs. dødeligheden.

Kvalitetsindikatorerne præsenteres i relation til struktur, proces og resultat med henblik på at belyse, hvilket grundlag der er for behandling af den pågældende sygdom (strukturen), hvilke aktiviteter (diagnostik, behandling, pleje, rehabilitering og forbyggelse) der er iværksat i relation til patientforløbene, samt hvilke resultater der opnås for patienterne, dvs patienternes helbredsgevinst.

Den generiske model som grundlag for præsentation af kvalitetsindikatorer er udviklet i erkendelse af, at en enkelt indikator sjældent alene kan beskrive kvaliteten af sundhedsvæsenets ydelser for et sygdomsområde.

Den grundlæggende ide med den generiske model er at beskrive en pakke af indikatorer, der tilsammen kan beskrive kvaliteten af sundhedsvæsenets ydelser i sammenhæng med sygdommens omfang og udvikling.

Da der er tale om en generisk model, betyder dette, at ikke alle modellens elementer vil være relevante for alle sygdomme eller alle kliniske tilstande.

Som det fremgår af den generiske model, indgår livskvalitet og patienttilfredshed i modellen. Projektgruppen har hermed ønsket at signalere, at der principielt bør inkluderes indikatorer til belysning heraf.

Der findes imidlertid ikke aktuelt data på nationalt niveau til belysning heraf. I relation til patienttilfredshed er der behov for udvikling af specifikke instrumenter, der kan belyse patienttilfredshed ved specifikke sygdomme.

Livskvalitet anvendes i stigende grad som supplerende effektmål ved vurdering af behandlingseffekt og helbredstilstand. Den mest anvendte metode til måling af livskvalitet er brug af spørgeskemaer. Før disse kan anvendes på nationalt og internationalt niveau, er der imidlertid behov for at sikre instrumenternes reliabilitet og validitet.

Som nævnt har den generiske model været udgangspunktet for udvikling af generiske og sygdomsspecifikke indikatorer.

Projektgruppen har valgt såkaldt prioriterede kvalitetsindikatorer, hvor de fleste nordiske lande umiddelbart kunne tilvejebringe valide data i relation til den generiske model. 


\subsection{Valg af prioriterede og potentielle kvalitetsindikatorer}

I afsnittet afrapporteres resultater for generiske og sygdomsspecifikke kvalitetsindikatorer inden for områderne:

- Kræftsygdomme

- Hjerte/karsygdomme

- Kroniske sygdomme

- Graviditet og fødsel

- Børn og unge

- Sundhedsfremme og forebyggelse

- Psykiatri

- Generiske indikatorer.

\subsubsection{Potentielle indikatorer}

Udover resultater er som afslutning for hvert område specificeret potentielle indikatorer. Disse potentielle indikatorer peges på som indikatorer, der bør videreudvikles i nordisk regi med henblik på fremtidig fælles nordisk benchmarking.

De valgte kvalitetsindikatorer for kræftsygdomme og hjerte/karsygdomme består fortrinsvis af struktur- og resultatindikatorer i form af overlevelse. For at fortolke forskellene her, vil det være optimalt med indikatorer, der belyser overensstemmelse mellem praksis og nationale kliniske retningslinjer. Det vil sige procesindikatorer og et bredere udvalg af resultatindikatorer (f.eks. behandlingskomplikationer og patientens funktionsniveau). Dette har været retningsgivende for forslagene vedrørende potentielle indikatorer.

For enkelte områder er der i de potentielle indikatorer peget på områder, der ikke er inkluderet i indeværende publikation (f.eks. hypertension inden for hjerte/karsygdomme), dette er en naturlig følge af, at de 8 områder dækker meget bredt, og der fremadrettet kan være behov for en udvidelse. Fremadrettet bør der også ske en udvidelse af området for kroniske sygdomme f.eks. i forhold til KOL-området. 


\subsubsection{Generelle kommentarer vedrørende sammenlignelighed}

Overordnet meningsfuld sammenligning af kvalitetsdata kræver fcelles forudsctninger for sundhedssystemerne

En sammenligning af resultater for kvalitetsindikatorer forudsætter at resultaterne kommer fra sammenlignelige systemer. F.eks. hvor befolkningsgrundlaget er ensartet sammensat og vilkårene for den organisatoriske tilrettelæggelse af sundhedsvæsenet er ensartede.

I indeværende rapport er kvalitetsindikatorer opgjort i forhold til Danmark, Finland, Færøerne, Grønland, Island, Norge og Sverige.

Det må her konstateres, at evt. forskelle i resultater for kvalitetsindikatorer mellem f.eks. Grønland og Sverige kan afspejle forskelle i geografiske/demografiske forhold og ikke nødvendigvis forskelle i kvaliteten for området. Her bør der i fortolkningen af indeværende rapports tabeller tages højde for de store forskelle i befolkningstal, hvor især Færøerne, Grønland og Islands resultater er behæftet med betydelig usikkerhed grundet lille befolkningstal ${ }^{1}$.

Samtidig bør der også være opmærksomhed på geografiske forskelle, der f.eks. kan påvirke sygehusdødeligheden for akutte sygdomme som følge af forskelle i tilgængelighed og transporttid til sygehuset.

\subsubsection{Betydning af sammenlignelige datakilder}

Sammenligning kræver ideelt set også ensartede datakilder. I indeværende rapport er disse ideelle betingelser ikke opfyldt. Datakilder i nedenstående svinger fra data indsamlet via spørgeskema til data fra kvalitetsregistre dedikeret den

\footnotetext{
${ }^{1}$ F.eks. uddybes dette af Grønland med følgende beskrivelse: Med et befolkningstal på omkring 56.000 indbyggere spredt langs kysten af den over 2 mill. km² store ø, har sundhedsvæsenet i Grønland særlige udfordringer. Sundhedsvæsenet er velfungerende på trods af en vanskelig infrastruktur med store geografiske afstande. Sundhedsvæsenet er ledelsesmæssigt organiseret i en samlet enhed under Sundhedsledelsen. Udover landshospitalet Dronning Ingrids Hospital med 185 senge i Nuuk, findes 15 små sygehuse og sundhedscentre i distrikterne. Teknisk set er sygehusene veludstyrede, og der findes elektronisk patientjournal og telemedicinsk udstyr i alle distrikter. Der er stor mangel på læger og sygeplejersker, som i stort omfang rekrutteres fra Danmark og de andre nordiske lande. Personalemæssigt giver det stort udskiftning af medarbejdere, og deraf følgende mangel på kontinuitet i pleje og behandling.

I forhold til anvendelse af indikatorer er det vigtigt, at det lille befolkningstal og dermed lille antal patienter tages i betragtning, når der er tale om registrering af antal tilfælde og antal sygehuse. Oplysningerne kan ikke umiddelbart sammenlignes med de øvrige nordiske lande.
} 
givne sygdom til patientadministrative systemer, ligesom opgørelsesårene er forskellige i flere tilfælde.

\subsubsection{Datakvalitet}

Datakvaliteten bør være ensartet høj - herunder samme opgørelsesperiode samt specificeret høj data- og databasekomplethed før resultaterne sammenlignes.

\subsubsection{Indikatordefinition}

Det skal for hver enkelt indikator også sikres, at der er enighed om definition af termer herunder definition af tæller og nævner i opgørelsen af resultater. Hvis for eksempel procentdelen af akutte kejsersnit i det ene land defineres som procentdel af alle fødsler, og $\mathrm{i}$ et andet land defineres som procentdelen af planlagt normal fødende, er resultaterne ikke sammenlignelige.

I indeværende projekt er der ikke for alle indikatorer udarbejdet specifikke fælles indikatoralgoritmer, og derfor bør der være fokus på mulighed for, at forskelle i resultater kan skyldes forskelle i definition af tæller/nævner. Data for incidens eller dødelighed bliver ofte vist som rater. For en given kræftform og population beregnes den rå rate (crude rate) ved at dividere antal nye kræfttilfælde eller kræftdødsfald i en given periode med det tilsvarende antal personår fra populationen under risiko. Når der er tale om kræft, angives resultatet oftest som en årlig rate per 100000 personår.

En standardiseret rate (ASR) er et samlet mål for den rate, som en befolkningsgruppe (population) ville have, hvis den havde en standard aldersstruktur. Standardisering er nødvendig når man skal sammenligne flere populationer med forskellig aldersstruktur, fordi alder har en så stor betydning for risikoen for at få kræft. ASR er et vægtet gennemsnit af de aldersspecifikke rater; vægtene er taget fra aldersfordelingen af standard populationen. 


\subsubsection{Krceftsygdomme}

Nedenfor er opgjort resultater for henholdsvis basis- og kvalitetsindikatorer for følgende områder:

- Lungekræft

- Brystkræft

- Livmoderhalskræft

- Prostatakræft

- Melanom

- Tyktarmskræft

- Endetarmskræft.

Heriblandt er der vedtaget følgende indikator vedr. mammografi-screening: Eksisterer der et nationalt screeningsprogram på området?, herunder procentdel, hvor screening har detekteret kræft.

Ingen af de nordiske lande har indleveret data for denne indikator, og den fremgår derfor ikke af tabellerne.

Begrundelse for valg af de respektive områder fremgår af de enkelte dataafsnit.

2.2.6.1 Lungekræft - begrundelse for valg af område

Lungekræft er en særdeles alvorlig sygdom med meget lav 5 års overlevelse og den 2. hyppigste kræftform blandt begge køn i de industrialiserede lande (OECD). 
Tabel 2.2.6.1.1 Eksempel på procesindikator, forskelle over tid og mellem regioner

\begin{tabular}{|c|c|c|c|c|c|}
\hline $\begin{array}{l}\text { Land (årstal- } \\
\text { /datakilde) }\end{array}$ & Incidensrate & $\begin{array}{l}\text { Alderstandar- } \\
\text { diseret } \\
\text { incidensrate }\end{array}$ & Prævalensrate & $\begin{array}{l}\text { Mortalitet, } \\
\text { crude }\end{array}$ & $\begin{array}{l}\text { Mortalitet, } \\
\text { alderstandar- } \\
\text { diseret }\end{array}$ \\
\hline & $\begin{array}{l}\text { Kvinder- } \\
\text { /Mænd } \\
\text { rate pr. } \\
100.000\end{array}$ & $\begin{array}{l}\text { Kvinder- } \\
\text { /Mænd } \\
\text { rate pr. } \\
100.000\end{array}$ & $\begin{array}{l}\text { Kvinderl } \\
\text { Mænd } \\
\text { rate pr. } \\
100.000\end{array}$ & $\begin{array}{l}\text { Kvinderl } \\
\text { Mænd } \\
\text { rate pr. } \\
100.000\end{array}$ & $\begin{array}{l}\text { Kvinderl } \\
\text { Mænd } \\
\text { rate pr. } \\
100.000\end{array}$ \\
\hline $\begin{array}{l}\text { Danmark } \\
\text { (2007/ } \\
\text { NORDCAN) }\end{array}$ & $72,4 / 83,4$ & $67,1 / 90,8$ & $106,0 / 121,0$ & $\begin{array}{l}62,2 / 77,2 / \\
N / A\end{array}$ & $\begin{array}{l}57,5 / 87,7 / \\
\text { N/A }\end{array}$ \\
\hline $\begin{array}{l}\text { Finland } \\
\text { (2007/ } \\
\text { NORDCAN) }\end{array}$ & $25,1 / 58,0$ & $20,8 / 63,7$ & $40,0 / 84,0$ & $\begin{array}{l}20,3 / 54,9 / \\
\text { N/A }\end{array}$ & $\begin{array}{l}16,8 / 61,7 / \\
\text { N/A }\end{array}$ \\
\hline $\begin{array}{l}\text { Færøerne } \\
\text { (2006/ } \\
\text { NORDCAN) }\end{array}$ & N/A & $\mathrm{N} / \mathrm{A}$ & N/A & $\begin{array}{l}8,6 / 43,8 / \\
\text { N/A }\end{array}$ & $\begin{array}{l}9,1 / 54,5 \\
\text { NA }\end{array}$ \\
\hline $\begin{array}{l}\text { Grønland } \\
\text { (2007/Dep. } \\
\text { for sundhed) }\end{array}$ & $76,7 / 131,4$ & $\mathrm{~N} / \mathrm{A}$ & N/A & $\begin{array}{l}71,3 / 96 \\
7 / 84,7\end{array}$ & N/A \\
\hline $\begin{array}{l}\text { Island } \\
\text { (2006-2008/ } \\
\text { NORDCAN) }\end{array}$ & $47,5 / 48,7$ & $56,6 / 68,6$ & $111,0 / 94,0^{\nabla}$ & $\begin{array}{l}43,4 / 40,9 / \\
\text { N/A }\end{array}$ & $\begin{array}{l}52,0 / 59,0 / \\
\text { N/A }\end{array}$ \\
\hline $\begin{array}{l}\text { Norge } \\
(2007 \\
\text { /NORDCAN) }\end{array}$ & $45,6 / 63,0$ & $44,3 / 73,5$ & $76,0 / 102,0$ & $\begin{array}{l}33,8 / 52,4 / \\
\text { N/A }\end{array}$ & $\begin{array}{l}32,5 / 62,4 / \\
\text { N/A }\end{array}$ \\
\hline $\begin{array}{l}\text { Sverige } \\
(2007 \\
\text { /NORDCAN) }\end{array}$ & $34,0 / 35,7$ & $29,2 / 35,4$ & $72,0 / 70,0$ & $\begin{array}{l}35,9 / 39,3 / \\
\text { N/A }\end{array}$ & $\begin{array}{l}30,1 / 39,3 / \\
\text { N/A }\end{array}$ \\
\hline
\end{tabular}

Tallene dækker 2006; $\nabla$ Tallet dækker alene 2007

Bemærkninger:

Der er ret markante forskelle i incidens/prævalens både på tværs af lande og køn, som må antages at hænge sammen med forskelle i rygemønster på tværs af lande og køn. 
Tabel 2.2.6.1.2 Lungekræft - kvalitetsindikatorer

\begin{tabular}{|c|c|c|c|}
\hline \multirow[t]{2}{*}{ Land (årstal/datakilde) } & \multirow[t]{2}{*}{$\begin{array}{l}\text { Nationalt klinisk } \\
\text { register/kliniske } \\
\text { retningslinjer }\end{array}$} & \multirow{2}{*}{$\begin{array}{l}5 \text { års observeret overlevel- } \\
\text { se (procentdel, der overle- } \\
\text { ver det } 5 \text {. år efter diagnose- } \\
\text { tidspunktet) (Cl) } \\
\text { Kvinder/Mænd }\end{array}$} & \multirow[t]{2}{*}{$\begin{array}{l}5 \text { års relativ overlevelse, } \\
\%(\mathrm{Cl}) \\
\text { Kvinder/Mænd }\end{array}$} \\
\hline & & & \\
\hline $\begin{array}{l}\text { Danmark } \\
\text { (2004/Dansk lunge- } \\
\text { cancerregister) }\end{array}$ & $\mathrm{Ja} / \mathrm{Ja}$ & $10(9 ; 11)^{\nabla}$ & N/A \\
\hline $\begin{array}{l}\text { Finland } \\
\text { (2002/Nomesko } \\
\text { temasektion om } \\
\text { kvalitetsindikatorer } \\
\text { (upubliceret)) }\end{array}$ & $\mathrm{Nej} / \mathrm{Ja}$ & $\begin{array}{l}12,5(11,1 ; 14,1) / \\
7,0(6,3 ; 7,8)\end{array}$ & $\begin{array}{l}15.0(13,2 ; 16,7) / \\
8,9(8,0 ; 9,9)\end{array}$ \\
\hline Færøerne & $\mathrm{Nej} / \mathrm{Nej}^{\natural 1}$ & N/A & N/A \\
\hline Grønland & $\mathrm{Nej} / \mathrm{Nej}{ }^{j \mathrm{jh}}$ & N/A & N/A \\
\hline $\begin{array}{l}\text { Island } \\
\text { (2003/Nomesko } \\
\text { temasektion om } \\
\text { kvalitetsindikatorer } \\
\text { (upubliceret)) }\end{array}$ & $\mathrm{Ja} / \mathrm{Ja}$ & $\begin{array}{l}15(\mathrm{~N} / \mathrm{A}) / \\
10(\mathrm{~N} / \mathrm{A})\end{array}$ & $\begin{array}{l}17(\mathrm{~N} / \mathrm{A}) / \\
11(\mathrm{~N} / \mathrm{A})\end{array}$ \\
\hline $\begin{array}{l}\text { Norge } \\
\text { (2001/Nomesko } \\
\text { temasektion om } \\
\text { kvalitetsindikatorer } \\
\text { (upubliceret)) }\end{array}$ & $\mathrm{Ja} / \mathrm{Ja}$ & $\begin{array}{l}13,9(5,0 ; 14,8) / \\
9,1(5,0 ; 13,1)\end{array}$ & $\begin{array}{l}11,2(8,6 ; 13,8)) / \\
10,6(8,5 ; 12,8)\end{array}$ \\
\hline $\begin{array}{l}\text { Sverige } \\
\text { (2004/cancerregistret) }\end{array}$ & $\mathrm{Ja} / \mathrm{Ja}^{\star} \square$ & $\begin{array}{l}14,1(11,9 ; 16,2) / \\
13,3(11,3 ; 15,2)\end{array}$ & $\begin{array}{l}15,3(13,0 ; 17,6) / \\
14,6(12,5 ; 16,7)\end{array}$ \\
\hline
\end{tabular}

$\nabla$ Samlet for begge køn. $\square$ Status pr. juli 2010. *Kliniske retningslinjer under udarbejdelse (publiceres dec. 2010) ${ }^{j}$ Der skal gøres opmærksom på, at resultater for 5 års overlevelse fra Danmark er hentet fra et veletableret nationalt klinisk register. ${ }^{\mathrm{h}}$ danske retningslinier tilpasset lokale forhold bruges.

Bemærkninger:

Island har den højeste overlevelse for såvel kvinder som mænd. Sygdommen rammer flere mænd end kvinder og 5 års overlevelsen er desuden lavere blandt mænd end kvinder. Islands højere overlevelse kan ikke umiddelbart forklares af forskelle i basisindikatorerne, men kan dog være udtryk for tilfældig variation, da Islands resultater er baseret på få patienter.

Der skal gøres opmærksom på, at resultater for 5 års overlevelse fra Danmark er hentet fra et veletableret nationalt klinisk register - resultater baseret på et klinisk register kan være baseret på en anden population end resultater fra et patientadministrativt system, og der bør udvises forsigtighed, når forskelle i resultater for 2 forskellige datakilder fortolkes. 
Figur 2.2.6.1.1 Eksempel på procesindikator, forskelle og tid mellem regioner

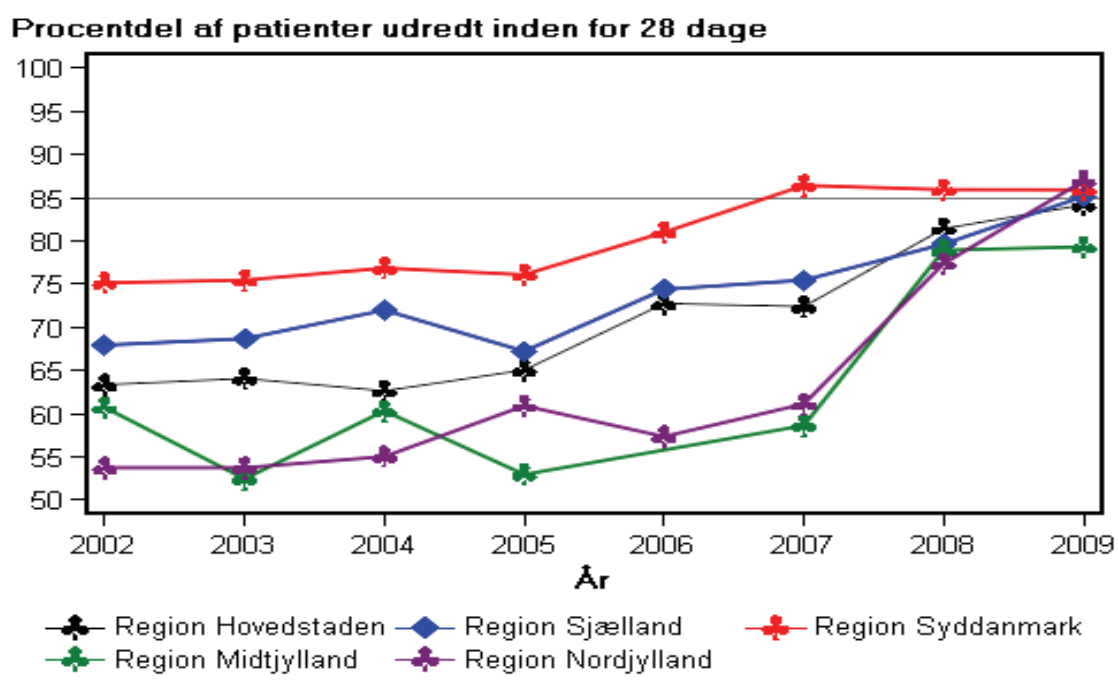

Kilde: Det nationale indikatorprojekt.

Grafen viser, at markant flere patienter er udredt inden for en tidsramme på 28 dage $i$ 2008 end tidligere i Danmark. Denne markante cendring skete i forbindelse med indførelse af krceftpakker, der opstillede mål for maksimal varighed af ventetid og udredning. Krceftpakkerne blev indført i Danmark efter periode med stor politisk fokus på udredningstider og ventetid til behandling, der var langere end fagligt anbefalet.

\subsubsection{Brystkræeft - begrundelse for valg af område}

Brystkræft er den hyppigste kræftform blandt kvinder med incidens på 11 \%, og ca. $3 \%$ af alle dødsfald blandt kvinder skyldes denne sygdom. (Feuer et al, 2003). Udgifter til behandling af brystkræft udgør ca. 0,5-0,6 \% af de totale sundhedsudgifter (OECD, 2003a). Dermed er brystkræft en hyppig og alvorlig diagnose, hvor der desuden er interventionsmuligheder og kendt variation i behandlingskvaliteten. 
Tabel 2.2.6.2.1 Brystkræft - basisindikatorer

\begin{tabular}{|c|c|c|c|c|c|}
\hline \multirow[t]{2}{*}{$\begin{array}{l}\text { Land (årstal- } \\
\text { /datakilde) }\end{array}$} & $\begin{array}{l}\text { Incidens- } \\
\text { rate }\end{array}$ & $\begin{array}{l}\text { Alderstandardiseret } \\
\text { incidensrate }\end{array}$ & $\begin{array}{l}\text { Prævalens- } \\
\text { rate }\end{array}$ & $\begin{array}{l}\text { Mortalitet, } \\
\text { crude }\end{array}$ & $\begin{array}{l}\text { Mortalitet, } \\
\text { alderstandar- } \\
\text { diseret }\end{array}$ \\
\hline & $\begin{array}{l}\text { Kvinder } \\
\text { rate pr. } \\
100.000\end{array}$ & $\begin{array}{l}\text { Kvinder } \\
\text { rate pr. } 100.000\end{array}$ & $\begin{array}{l}\text { Kvinder } \\
\text { rate pr. } \\
100.000\end{array}$ & $\begin{array}{l}\text { Kvinder } \\
\text { rate pr. } \\
100.000\end{array}$ & $\begin{array}{l}\text { Kvinder } \\
\text { rate pr. } 100.000\end{array}$ \\
\hline $\begin{array}{l}\text { Danmark } \\
\text { (2007/ } \\
\text { NORDCAN) }\end{array}$ & 147,9 & 136,3 & 1.539 & 45,4 & $40,4 \square$ \\
\hline $\begin{array}{l}\text { Finland } \\
\text { (2007/ } \\
\text { NORDCAN) }\end{array}$ & 148,0 & 129,6 & 1.506 & 29,5 & 24,8 \\
\hline $\begin{array}{l}\text { Færøerne } \\
\text { (2006/ } \\
\text { NORDCAN) }\end{array}$ & N/A & N/A & N/A & 4,3 & 4,4 \\
\hline $\begin{array}{l}\text { Grønland } \\
\text { (2007/Dep. } \\
\text { for sundhed) }\end{array}$ & 60,1 & N/A & N/A & 0 & N/A \\
\hline $\begin{array}{l}\text { Island } \\
\text { (2006-2008/ } \\
\text { NORDCAN) }\end{array}$ & 121,9 & 138,5 & $1.585^{\nabla}$ & 28,3 & 32,8 \\
\hline $\begin{array}{l}\text { Norge } \\
(2007 / \\
\text { NORDCAN) }\end{array}$ & 115,2 & 112,0 & 1.341 & $28,7^{\square}$ & 26,4 \\
\hline $\begin{array}{l}\text { Sverige } \\
(2007 / \\
\text { NORDCAN) }\end{array}$ & 135,1 & 120,9 & 1.533 & 32,1 & 26,1 \\
\hline
\end{tabular}

Tallene dækker 2006; ${ }^{\nabla}$ Tallet dækker alene 2007

Bemærkninger:

Resultaterne viser nogle forskelle mellem de nordiske lande i incidens og mortalitet, hvor incidensen af brystkræft i de nordiske lande ligger mellem 112 pr. 100.000 (nordiske standardpopulation) og 136 pr. 100.000. Dvs. den højeste incidens (Danmark) er godt $20 \%$ større end den laveste (Norge). De 3 resterende landes incidens ligger dog meget tæt på hinanden.

For de enkelte lande i 2006/2007 svinger den justerede mortalitetsrate mellem 24,8 og 40,4 pr. 100.000 (her bortset fra Færøerne), hvor Danmarks rate afviger markant fra de andre lande. Prævalensen er mere ensartet, hvor kun Norges afviger fra et niveau omkring 1.500. Deres lavere prævalens hænger godt sammen med den ligeledes lavere alderstandardiserede incidens. 
Tabel 2.2.6.2.2 Brystkræft - kvalitetsindikatorer

\begin{tabular}{|c|c|c|c|c|c|c|}
\hline $\begin{array}{l}\text { Land (årstal- } \\
\text { /datakilde) }\end{array}$ & $\begin{array}{r}\text { Nationalt } \\
\text { klinisk } \\
\text { register- } \\
\text { /kliniske } \\
\text { retnings- } \\
\text { linjer }\end{array}$ & $\begin{array}{r}\text { Eksisterer } \\
\text { der et } \\
\text { nationalt } \\
\text { scree- } \\
\text { ningspro- } \\
\text { gram på } \\
\text { området? }\end{array}$ & $\begin{array}{r}\text { Mammogra- } \\
\text { fiscreening: } \\
\text { Procentdel, } \\
\text { hvor } \\
\text { screening } \\
\text { har detekte- } \\
\text { ret tumorer } \\
\text { mindre end } \\
\text { eller lig } 1 \\
\mathrm{~cm}\end{array}$ & $\begin{array}{r}\text { Pro- } \\
\text { centdel, } \\
\text { der er } \\
\text { scree- } \\
\text { net, \% }\end{array}$ & $\begin{array}{r}5 \text { års observe- } \\
\text { ret overlevel- } \\
\text { se (procent- } \\
\text { del, der } \\
\text { overlever det } \\
5 . \text { år efter } \\
\text { diagnosetids- } \\
\text { punktet) }(\mathrm{Cl})\end{array}$ & $\begin{array}{l}5 \text { års relativ } \\
\text { overlevelse, } \\
\%(\mathrm{Cl})\end{array}$ \\
\hline $\begin{array}{l}\text { Danmark } \\
(2002 / O E C D)\end{array}$ & $\mathrm{Ja} / \mathrm{Ja}$ & $\mathrm{Ja}$ & N/A & N/A' & $\begin{array}{r}77,0 \\
(75,0 ; 78,0)\end{array}$ & $\begin{array}{r}85,0 \\
(83,0 ; 85,0)\end{array}$ \\
\hline $\begin{array}{l}\text { Finland } \\
(2002 / O E C D)\end{array}$ & $\mathrm{Ja} / \mathrm{Ja}$ & $\mathrm{Ja}$ & N/A & $86,2^{g}$ & $\begin{array}{r}75,0 \\
(74,0: 76,0)\end{array}$ & $\begin{array}{r}86,0 \\
(85,0: 87,0)\end{array}$ \\
\hline Færøerne & $\mathrm{Nej} / \mathrm{Nej}$ & Nej & N/A & N/A & $\mathrm{N} / \mathrm{A}$ & $\mathrm{N} / \mathrm{A}$ \\
\hline Grønland & $\mathrm{Nej} / \mathrm{Nej}^{-1}$ & $\mathrm{~N} / \mathrm{A}$ & $\mathrm{N} / \mathrm{A}$ & N/A & $\mathrm{N} / \mathrm{A}$ & $\mathrm{N} / \mathrm{A}$ \\
\hline $\begin{array}{l}\text { Island } \\
\text { (2003/OECD) }\end{array}$ & $\mathrm{Ja} / \mathrm{Nej}$ & $\mathrm{Ja}$ & N/A & $62,0^{g}$ & $\begin{array}{r}77,4 \\
(74,0 ; 80,1)\end{array}$ & $\begin{array}{r}88,3 \\
(83,8 ; 92,7)\end{array}$ \\
\hline $\begin{array}{l}\text { Norge } \\
(2001 / O E C D)\end{array}$ & $\mathrm{Nej} / \mathrm{Ja}$ & $\mathrm{Ja}$ & $30,7^{\nabla}$ & $77,0^{*}$ & $\begin{array}{r}72,5 \\
(69,0 ; 76,0)\end{array}$ & $\begin{array}{r}81,9 \\
(80,0 ; 84,2)\end{array}$ \\
\hline $\begin{array}{l}\text { Sverige } \\
(2003 / O E C D)\end{array}$ & $\mathrm{Ja} / \mathrm{Ja}$ & $\mathrm{Ja}$ & N/A & N/A' & $\begin{array}{r}76,1 \\
(75,1 ; 77,1)\end{array}$ & $\begin{array}{r}86,1 \\
(84,8 ; 87,5)\end{array}$ \\
\hline
\end{tabular}

Status pr. juli 2010. ${ }^{\nabla}$ kræftregistret, Norge - dækker 2009; *kræftregistret, Norge - dækker 2008; '। 2009 er oplyst, at alle kvinder mellem (40)50-69 år tilbydes screening i landet, men der foreligger ikke oplysninger, om hvor mange tager imod tilbuddet. ${ }^{9} \mathrm{Health}$ at a Glance, 2009, OECD indicators (resultater fra 2006). ${ }^{1}$ danske retningslinier tilpasset lokale forhold bruges.

Bemærkninger:

Der er nogle forskelle på 5 års overlevelsen på tværs af de nordiske lande, men disse kan hænge sammen med, at resultaterne for landet med den lave overlevelse stammer fra det tidligste år, hvor overlevelsen har været stigende.

\subsubsection{Livmoderhalskrceft - begrundelse for valg af område}

Kræft i livmoderhalsen kan forebygges via tidlig sporing. Herudover er det en kræftform, hvor der i de senere år er udviklet vacciner. Forskelle i prævalens, incidens, dødelighed og overlevelse vil hænge tæt sammen med forskelle i effektivitet af screeningsprogrammer. 
Tabel 2.2.6.3.1 Livmoderhalskræft - basisindikatorer

\begin{tabular}{|c|c|c|c|c|c|}
\hline \multirow[t]{2}{*}{$\begin{array}{l}\text { Land (års- } \\
\text { tal/datakilde) }\end{array}$} & $\begin{array}{l}\text { Incidens- } \\
\text { rate }\end{array}$ & $\begin{array}{l}\text { Alderstandardi- } \\
\text { seret incidensra- } \\
\text { te }\end{array}$ & $\begin{array}{l}\text { Prævalens- } \\
\text { rate }\end{array}$ & $\begin{array}{l}\text { Mortalitet, } \\
\text { crude }\end{array}$ & $\begin{array}{l}\text { Mortalitet, } \\
\text { alderstan- } \\
\text { dardiseret }\end{array}$ \\
\hline & $\begin{array}{l}\text { Kvinder } \\
\text { rate pr. } \\
100.000\end{array}$ & $\begin{array}{l}\text { Kvinder } \\
\text { rate pr. } 100.000\end{array}$ & $\begin{array}{l}\text { Kvinder } \\
\text { rate pr. } \\
100.000\end{array}$ & $\begin{array}{l}\text { Kvinder } \\
\text { rate pr. } \\
100.000\end{array}$ & $\begin{array}{l}\text { Kvinder } \\
\text { rate pr. } \\
100.000\end{array}$ \\
\hline $\begin{array}{l}\text { Danmark } \\
\text { (2007/NORDCAN) }\end{array}$ & 14,4 & 14,2 & 310 & 3,9 & 3,6 \\
\hline $\begin{array}{l}\text { Finland } \\
\text { (2007/NORDCAN) }\end{array}$ & 5,1 & 4,9 & 89 & 1,6 & 1,3 \\
\hline $\begin{array}{l}\text { Færøerne } \\
\text { (2006/NORDCAN) }\end{array}$ & N/A & N/A & N/A & 0 & 0 \\
\hline $\begin{array}{l}\text { Grønland (2007/ } \\
\text { Dep. for sundhed) }\end{array}$ & N/A & 33,8 & N/A & 15,0 & N/A \\
\hline $\begin{array}{l}\text { Island } \\
\text { (2006-2008/ } \\
\text { NORDCAN) }\end{array}$ & 7,9 & 8,3 & $233^{\nabla}$ & 1,1 & 1,3 \\
\hline $\begin{array}{l}\text { Norge } \\
(2007 / N O R D C A N)\end{array}$ & 10,9 & 11,1 & 277 & 3,4 & 3,3 \\
\hline $\begin{array}{l}\text { Sverige } \\
\text { (2007/NORDCAN) }\end{array}$ & 10,1 & 9,8 & 170 & 3,5 & 3,1 \\
\hline
\end{tabular}

Tallene dækker 2006; ${ }^{\nabla}$ Tallet dækker alene 2007

Bemærkninger:

Incidens af kræft i livmoderhals i de nordiske lande ligger mellem 4,9 pr. 100.000 (nordisk standardpopulation) og 14,2 pr. 100.000. Dvs. der er markant spredning på incidensen. Tilsvarende markante forskelle ses i prævalensen.

Den justerede mortalitetsrate var i 2006 på 2,6 pr. 100.000. I årene 2006-2007 svingede den en del mellem de enkelte lande (fra 1,3 og 3,6 pr. 100.000). Hvor Islands og Finlands rater er markant lavere end de 3 andre lande. 
Tabel 2.2.6.3.2 Livmoderhalskræft - kvalitetsindikatorer

\begin{tabular}{|c|c|c|c|c|c|}
\hline $\begin{array}{l}\text { Land (års- } \\
\text { tal/datakilde) }\end{array}$ & $\begin{array}{l}\text { Nationalt } \\
\text { klinisk } \\
\text { register- } \\
\text { /kliniske } \\
\text { retningslinjer }\end{array}$ & $\begin{array}{l}\text { Eksisterer } \\
\text { der et natio- } \\
\text { nalt scree- } \\
\text { nings- } \\
\text { program på } \\
\text { området? }\end{array}$ & $\begin{array}{l}\text { Procentdel } \\
\text { Kvinder, der } \\
\text { er screenet, } \\
\% \text { (alder } \\
\text { 20-69) }\end{array}$ & $\begin{array}{l}5 \text { års obser- } \\
\text { veret overle- } \\
\text { velse (pro- } \\
\text { centdel, der } \\
\text { overlever det } \\
5 \text {. år efter } \\
\text { diagnose- } \\
\text { tidspunktet) } \\
\text { (Cl) }\end{array}$ & $\begin{array}{l}5 \text { års relativ } \\
\text { overlevelse, } \\
\%(\mathrm{Cl})\end{array}$ \\
\hline $\begin{array}{l}\text { Danmark } \\
(2002 / O E C D)\end{array}$ & $\mathrm{Ja} / \mathrm{Ja}$ & $\mathrm{Ja}$ & $69,4^{g}$ & $\begin{array}{l}58,3 \\
(47,2 ; 69,5)\end{array}$ & $\begin{array}{l}61,3 \\
(48,9 ; 73,7)\end{array}$ \\
\hline $\begin{array}{l}\text { Finland } \\
(2002 / O E C D)\end{array}$ & $\mathrm{Ja} / \mathrm{Nej}$ & $\mathrm{Ja}$ & $70,5^{g} / 69,8^{t}$ & $\begin{array}{l}66,0 \\
(62,0 ; 69,0)\end{array}$ & $\begin{array}{l}69,0 \\
(65,0 ; 73,0)\end{array}$ \\
\hline Færøerne & $\mathrm{Nej} / \mathrm{Nej}$ & $\mathrm{Ja}$ & $N / A^{\prime}$ & N/A & N/A \\
\hline Grønland & $\mathrm{Nej} / \mathrm{Nej}^{1}$ & N/A & Nej & Ikke relevant & N/A \\
\hline $\begin{array}{l}\text { Island } \\
(2003 / O E C D)\end{array}$ & $\mathrm{Ja} / \mathrm{Nej}^{\square}$ & $\mathrm{Ja}$ & $71,0^{g}$ & $\begin{array}{l}50,9 \\
(37,7 ; 64,1)\end{array}$ & $\begin{array}{l}71,0 \\
(60,3 ; 81,8)\end{array}$ \\
\hline $\begin{array}{l}\text { Norge } \\
(2001 / O E C D)\end{array}$ & $\mathrm{Nej} / \mathrm{Ja}$ & $\mathrm{Ja}$ & $75,6^{g}$ & $\begin{array}{l}62,4 \\
(50,1 ; 74,7)\end{array}$ & $\begin{array}{l}65,9 \\
(59,4 ; 72,4)\end{array}$ \\
\hline $\begin{array}{l}\text { Sverige } \\
\text { (2003/OECD) }\end{array}$ & $\mathrm{Ja} / \mathrm{Nej}^{\square}$ & $\mathrm{Ja}$ & $78,6^{g}$ & $\begin{array}{l}62,9 \\
(58,4 ; 67,4)\end{array}$ & $\begin{array}{l}65,8 \\
(61,0 ; 70,7)\end{array}$ \\
\hline
\end{tabular}

Status pr. juli 2010; '। 2009 er oplyst, at alle kvinder mellem 23-65 år tilbydes screening, men der foreligger ikke oplysninger, om hvor mange tager imod tilbuddet. ${ }^{9} \mathrm{Health}$ at a Glance, 2009, OECD indicators (resultater fra 2006) 'Data leveret til OECD, Health at a Glance, 2010, ukendt opgørelsesår, men sandsynligvis nyere tal end først anførte.

${ }^{1}$. Danske retningslinier tilpasset lokale forhold bruges.

Bemærkninger:

Alle lande på nær Færøerne har enten et nationalt klinisk register og/eller kliniske retningslinjer, ligesom alle lande har et screeningsprogram, hvor tal fra 2006 viser, at ca 70-80 \% af kvinder tilbydes screening. Disse oplysninger er fra OECD, hvor det ikke er specificeret, om der er tale om screening hver 3. eller 5. år, hvilket kan have betydning for fortolkningen.

Der er ikke signifikante forskelle på 5 års overlevelsen - det ville kræve adgang til resultater for en større årrække for at vurdere, om de forskelle, der spores i 5 års overlevelsen er betydningsfulde, da forskellene i det enkelte opgjorte år ikke er signifikante jf. de overlappende konfidensintervaller. Norges screeningsprogram blev indført noget senere end de andre nordiske landes (1992), mens Danmarks først blev fuldt udrullet i 2006 (Nomesko temasektion om kvalitetsindikatorer (upubliceret) - dette kan forklare, at de 2 landes mortalitet jf. tabel 1.3.1. er markant højere.

\subsubsection{Prostatakrceft - begrundelse for valg af område}

Prostatacancer er den tredje hyppigste cancerform blandt mænd og den hyppigste i urinvejene. Tilfældene er kraftigt stigende fra 50 til 80 års alderen, og ved obduktioner af mænd over 50 år, som er døde af anden årsag, finder man prostatacancer i $30 \%$ af tilfældene. Ved obduktion af mænd, som har fået 
fjernet dele af prostata pga. prostatahypertrofi, ses der i $10 \%$ af tilfældene prostatacancer. Der er i forskellig grad indført screening med PSA-test for sygdommen, men der er uenighed om effekten af denne $(1,2)$.

Tabel 2.2.6.4.1 Prostatakræft - basisindikatorer

\begin{tabular}{|c|c|c|c|c|c|}
\hline \multirow[t]{2}{*}{$\begin{array}{l}\text { Land (årstal/- } \\
\text { datakilde) }\end{array}$} & Incidensrate & $\begin{array}{l}\text { Alderstan- } \\
\text { dardiseret } \\
\text { incidensrate }\end{array}$ & $\begin{array}{l}\text { Prævalens- } \\
\text { rate }\end{array}$ & $\begin{array}{l}\text { Mortalitet, } \\
\text { crude }\end{array}$ & $\begin{array}{l}\text { Mortalitet, } \\
\text { alderstan- } \\
\text { dardiseret }\end{array}$ \\
\hline & $\begin{array}{l}\text { Mænd } \\
\text { rate pr. } \\
100.000\end{array}$ & $\begin{array}{l}\text { Mænd } \\
\text { rate pr. } \\
100.000\end{array}$ & $\begin{array}{l}\text { Mænd } \\
\text { rate pr. } \\
100.000\end{array}$ & $\begin{array}{l}\text { Mænd } \\
\text { rate pr. } \\
100.000\end{array}$ & $\begin{array}{l}\text { Mænd } \\
\text { rate pr. } \\
100.000\end{array}$ \\
\hline $\begin{array}{l}\text { Danmark } \\
\text { (2007/NORDCAN) }\end{array}$ & 133,2 & 143,6 & 663 & 43,8 & $58,6^{1}$ \\
\hline $\begin{array}{l}\text { Finland } \\
\text { (2007/NORDCAN) }\end{array}$ & 161,7 & 173,8 & 1.478 & 30,4 & 42,5 \\
\hline $\begin{array}{l}\text { Færøerne } \\
\text { (2006/NORDCAN) }\end{array}$ & N/A & N/A & N/A & 31,9 & 41,1 \\
\hline $\begin{array}{l}\text { Grønland } \\
\text { (2007/Dep. for } \\
\text { sundhed) }\end{array}$ & 30,0 & $\mathrm{~N} / \mathrm{A}$ & N/A & 6,7 & N/A \\
\hline $\begin{array}{l}\text { Island } \\
\text { (2006-2008/ } \\
\text { NORDCAN) }\end{array}$ & 148,9 & 210,1 & $1.469^{\nabla}$ & 30,4 & 50,0 \\
\hline $\begin{array}{l}\text { Norge } \\
(2007 / \text { NORDCAN) }\end{array}$ & 187,8 & 216,8 & 1.323 & 44,9 & 58,9 \\
\hline $\begin{array}{l}\text { Sverige } \\
\text { (2007/NORDCAN) }\end{array}$ & 194,9 & 188,4 & 1.475 & 54,4 & 58,6 \\
\hline
\end{tabular}

${ }_{1}$ S Sundhedsstyrelsen, „Kræftprofil, prostata“, 2009 er afrapporteret mortalitetstal for 2007, der indikerer, at mortaliteten er let faldende. Tallene er ikke fuldt sammenlignelige med resultaterne fra Nordcan, da de er justeret efter en dansk standardpopulation, men disse opdaterede tal viser et fald på 5 procentpoint i mortaliteten fra 2006 til $2007 \mathrm{i}$ Danmark. $\square$ Tallene dækker 2006; ${ }^{\nabla}$ Tallet dækker alene 2007

Bemærkninger:

Incidens af kræft i blærehalskirtlen i de nordiske lande ligger mellem 143,6 pr. 100.000 (nordisk standardpopulation) og 216,8 pr. 100.000. Dvs. den højeste incidens (Norge) er over $50 \%$ større end den laveste (Danmark). Danmark skiller sig ud fra det nordiske gennemsnit, men sammenlignet med tidligere år er Danmarks resultat kommet nærmere de resterende nordiske lande.

Den justerede mortalitetsrate i Norden var i 2006 på 56,5 pr. 100.000. Den svingede i 2006/2007 mellem 42,5 og 58,9 pr. 100.000 . Finlands rate afviger fra øvrige lande, hvor supplerende resultater $\mathrm{i}$ øvigt viser, at Finlands mortalitetsrate er faldet over tid (NORDCAN). 
Tabel 2.2.6.4.2 Prostatakræft - kvalitetsindikatorer

\begin{tabular}{|c|c|c|c|c|c|}
\hline $\begin{array}{l}\text { Land (årstal- } \\
\text { /datakilde) }\end{array}$ & $\begin{array}{l}\text { Nationalt } \\
\text { klinisk } \\
\text { regi- } \\
\text { ster/kliniske } \\
\text { retningslinjer }\end{array}$ & $\begin{array}{l}\text { Procentdel } \\
\text { Mænd, der er } \\
\text { screenet, } \\
\text { (alder 20-69) }\end{array}$ & $\begin{array}{l}\text { Procentdel } \\
\text { Mænd, der er } \\
\text { screenet for } \\
\text { prostataspe- } \\
\text { cifik antigen } \\
\text { med PSA } \\
\text { analyse }\end{array}$ & $\begin{array}{l}5 \text { års obser- } \\
\text { veret overle- } \\
\text { velse (pro- } \\
\text { centdel, der } \\
\text { overlever det } \\
5 . \text { år efter } \\
\text { diagnosetids- } \\
\text { punktet) (Cl) }\end{array}$ & $\begin{array}{l}5 \text { års relativ } \\
\text { overlevelse, } \\
\%(\mathrm{Cl})\end{array}$ \\
\hline $\begin{array}{l}\text { Danmark } \\
\text { (2000/Kræftens } \\
\text { Bekæmpelse, } \\
\text { Danmark) }\end{array}$ & $\mathrm{Nej} / \mathrm{Ja}$ & N/A & N/A & N/A & 43 (NA) \\
\hline $\begin{array}{l}\text { Finland } \\
\text { (2002/ Nomesko } \\
\text { temasektion om } \\
\text { kvalitetsindikatorer } \\
\text { (upubliceret)) }\end{array}$ & $\mathrm{Nej} / \mathrm{Ja}$ & N/A & N/A & 73 (NA) & 92 (NA) \\
\hline Færøerne & $\mathrm{Nej} / \mathrm{Nej}^{\square}$ & N/A & N/A & N/A & $\mathrm{N} / \mathrm{A}$ \\
\hline Grønland & $\mathrm{Nej} / \mathrm{Nej}^{{ }^{1}}$ & N/A & N/A & $\mathrm{N} / \mathrm{A}$ & $\mathrm{N} / \mathrm{A}$ \\
\hline $\begin{array}{l}\text { Island } \\
\text { (2003/Nomesko } \\
\text { temasektion om } \\
\text { kvalitetsindikatorer } \\
\text { (upubliceret)) }\end{array}$ & $\mathrm{Ja} / \mathrm{Nej}^{-}$ & N/A & N/A & 68 (NA) & 81 (NA) \\
\hline $\begin{array}{l}\text { Norge } \\
\text { (2001/Nomesko } \\
\text { temasektion om } \\
\text { kvalitetsindikatorer } \\
\text { (upubliceret)) }\end{array}$ & $\mathrm{Ja} / \mathrm{Ja}$ & N/A & N/A & $\begin{array}{l}67,2 \\
(60,3 ; 74,1)\end{array}$ & $\begin{array}{l}86,1 \\
(81,7 ; 90,5)\end{array}$ \\
\hline $\begin{array}{l}\text { Sverige } \\
\text { (2004/cancer- } \\
\text { registret) }\end{array}$ & $\mathrm{Ja} / \mathrm{Nej}^{\square}$ & N/A & N/A & $\begin{array}{l}75,9 \\
(75,0 ; 76,7)\end{array}$ & $\begin{array}{l}89,3 \\
(88,2 ; 90,5)\end{array}$ \\
\hline
\end{tabular}

$\square$ Status pr. juli 2010. ${ }^{1}$ Danske retningslinier tilpasset lokale forhold bruges.

Bemærkninger:

Der er ikke data for samme år og samme typer datakilder for 5 års overlevelsen, ligesom der ikke er konfidensintervaller - og det er derfor ikke muligt at konkludere om forskellen er signifikant. Det er bemærkelsesværdigt, at Finland har en højere overlevelse end Norge og Island, samt at Danmarks overlevelse er lavere end de andre landes. Finlands højere overlevelse kan hænge sammen med, at incidensen i perioder har været højere i samme land. Dette kunne indikere, at lettere sygdomstilfælde i højere grad opdages i Finland, hvor der da også har været gennemført forsøg med screening. Forskellene i overlevelse er dermed ikke nødvendigvis udtryk for forskelle i behandlingskvaliteten, men derimod udtryk for forskelle i opsporing af sygdomstilfælde - en endelig konklusion her vil kræve adgang til oplysninger om screening, som det p.t. ikke har været muligt at fremskaffe i nogle af de nordiske lande.

Det skal bemærkes, at i de seneste år er mortaliteten i Finland samtidig faldet i forhold til resten af Norden, hvilket kan indikere, at kvaliteten af behandlingen er forbedret 


\subsubsection{Melanom (modermcerkekræeft) - begrundelse for valg af område}

Malignt melanom er hyppigt forekommende - udgør omkring $4 \%$ af alle kræfttilfælde. Prognosen er god ved tidlig opsporing, men malignt melanom er trods det den næsthyppigste kræft-dødsårsag i aldersgruppe 15-35 år i Danmark. Incidensen har været markant stigende over de sidste 50 år i alle nordiske lande. Der foregår i alle nordiske lande forebyggelsesaktiviteter rettet mod befolkningens uv-eksposition.

Tabel 2.2.6.5.1 melanom - basisindikatorer ${ }^{\square}$

\begin{tabular}{|c|c|c|c|c|c|}
\hline \multirow[t]{2}{*}{ Land (årstal/datakilde) } & \multirow{2}{*}{$\begin{array}{l}\text { Incidens- } \\
\text { rate } \\
\text { Kvinder- } \\
\text { IMænd } \\
\text { rate pr. } \\
100.000\end{array}$} & \multirow{2}{*}{$\begin{array}{l}\text { Alderstan- } \\
\text { dardiseret } \\
\text { incidensrate } \\
\text { Kvinder- } \\
\text { IMænd } \\
\text { rate pr. } \\
100.000\end{array}$} & \multirow{2}{*}{$\begin{array}{l}\text { Prævalens- } \\
\text { rate } \\
\text { Kvinder- } \\
\text { /Mænd } \\
\text { rate pr. } \\
100.000\end{array}$} & \multirow{2}{*}{$\begin{array}{l}\text { Mortalitet, } \\
\text { crude } \\
\text { Kvinder- } \\
\text { /Mænd } \\
\text { rate pr. } \\
100.000\end{array}$} & \multirow{2}{*}{$\begin{array}{l}\text { Mortalitet, } \\
\text { alderstan- } \\
\text { dardiseret } \\
\text { Kvinder- } \\
\text { /Mænd } \\
\text { rate pr. } \\
100.000\end{array}$} \\
\hline & & & & & \\
\hline $\begin{array}{l}\text { Danmark } \\
\text { (2007/NORDCAN) }\end{array}$ & $28,3 / 25,3$ & $27,1 / 26,6$ & $344 / 240$ & $3,8 / 4,7$ & $3,4 / 5,1$ \\
\hline $\begin{array}{l}\text { Finland } \\
\text { (2007/NORDCAN) }\end{array}$ & $16,3 / 17,3$ & $14,5 / 18,1$ & $176 / 183$ & $2,7 / 4,4$ & $2,3 / 4,8$ \\
\hline $\begin{array}{l}\text { Færøerne } \\
\text { (2006/NORDCAN) }\end{array}$ & N/A & N/A & $296 / 145$ & $0 / 4,0$ & $0 / 4,3$ \\
\hline $\begin{array}{l}\text { Grønland (2007/ Dep. } \\
\text { for sundhed) }\end{array}$ & $11,3 / 13,3$ & N/A & $394 / 306$ & 0 & N/A \\
\hline $\begin{array}{l}\text { Island } \\
\text { (2007/NORDCAN) }\end{array}$ & $22,3 / 13,2$ & $24,0 / 17,9$ & $292 / 259$ & $5,2 / 1,9$ & $6,2 / 2,4$ \\
\hline $\begin{array}{l}\text { Norge } \\
(2007 / N O R D C A N)\end{array}$ & $26,5 / 24,2$ & $25,6 / 26,8$ & $344 / 240$ & $4,1 / 7,6$ & $3,9 / 8,6$ \\
\hline $\begin{array}{l}\text { Sverige } \\
(2007 / N O R D C A N)\end{array}$ & $24,5 / 23,2$ & $22,4 / 23,1$ & $330 / 262$ & $4,5 / 5,9$ & $3,7 / 5,9$ \\
\hline
\end{tabular}

Data stammer fra Nordcan og dækker både hud- og modermærkekræft.

\section{Bemærkninger}

Der er ikke adgang til oplysninger om basisindikatorerne alene for melanom, da indeværende tal er samlet for hud- og modermærkekræft. De 2 kræftformer har forskellige overlevelsesgrader, så det bør efterstræbes at sikre opdelte tal.

Incidensen varierer mellem de nordiske lande, hvor Finlands er markant lavere end de resterende lande. Alene Island har større kønsforskelle i incidens, hvilket må antages at skyldes den usikkerhed, der følger af det lille befolkningsgrundlag. Mens incidensen for de 2 køn dermed er forholdsvis ens, er prævalensen noget større blandt kvinder end mænd, hvilket hænger sammen med de 2 køns forskellige mortalitet; den justerede mortalitet svinger mellem 2,3 for finske kvinder og 8,6 for norske mænd. Resultaterne viser ganske markante forskelle i mortaliteten på tværs af de nordiske lande.

Forskellene i mortaliteten forklares ikke umiddelbart af forskelle i basisindikatorerne, og det kan være relevant at undersøge hvad årsagerne til forskellene er - det må dog anbefales først at undersøge, om samme mønster gør sig gældende for de opdelte tal for hhv. modermærke- og hudkræft. 
Tabel 2.2.6.5.2 Melanom - kvalitetsindikatorer

\begin{tabular}{|c|c|c|c|c|}
\hline \multirow[t]{2}{*}{ Land (årstal/datakilde) } & \multirow[t]{2}{*}{$\begin{array}{l}\text { Nationalt klinisk } \\
\text { register/kliniske } \\
\text { retningslinjer }\end{array}$} & \multirow[t]{2}{*}{$\begin{array}{l}5 \text { års observeret } \\
\text { overlevelse } \\
\text { (procentdel, der } \\
\text { overlever det } 5 . \\
\text { år efter diagno- } \\
\text { setidspunktet) } \\
\text { (Cl) } \\
\text { Kvinder/Mænd }\end{array}$} & \multirow[t]{2}{*}{$\begin{array}{l}5 \text { års relativ } \\
\text { overlevelse, \% } \\
\text { (CI) } \\
\text { Kvinder/Mænd }\end{array}$} & \multirow[t]{2}{*}{$\begin{array}{l}30 \text { dages } \\
\text { dødelighed efter } \\
\text { operation, } \\
\text { procentdel død } \\
30 \text { dage efter } \\
\text { operationen (Cl) }\end{array}$} \\
\hline & & & & \\
\hline $\begin{array}{l}\text { Danmark } \\
\text { (2004/www.cancer.dk) }\end{array}$ & $\mathrm{Ja} / \mathrm{JNej}$ & N/A & $\begin{array}{l}91(\mathrm{~N} / \mathrm{A}) \\
/ 82(\mathrm{~N} / \mathrm{A})\end{array}$ & $\mathrm{N} / \mathrm{A}$ \\
\hline $\begin{array}{l}\text { Finland } \\
\text { (2008/ud- } \\
\text { skrivningsregistret }^{y} \text { ) }\end{array}$ & $\mathrm{Ja} / \mathrm{Ja}$ & $\mathrm{N} / \mathrm{A}$ & $\mathrm{N} / \mathrm{A}$ & $0,1(\mathrm{NA})$ \\
\hline Færøerne & $\mathrm{Nej} / \mathrm{Nej}$ & N/A & N/A & N/A \\
\hline Grønland & $\mathrm{Nej} / \mathrm{Nej}{ }^{\square}$ & N/A & N/A & N/A \\
\hline Island & $\mathrm{Ja} / \mathrm{Nej}$ & N/A & N/A & N/A \\
\hline $\begin{array}{l}\text { Norge } \\
\text { (2001/ Nomesko } \\
\text { temasektion om } \\
\text { kvalitetsindikatorer } \\
\text { (upubliceret)) }\end{array}$ & $\mathrm{Ja} / \mathrm{Ja}$ & $\begin{array}{l}81,0 \\
(73,8 ; 88,1) / \\
71,5 \\
(62,9 ; 80,0)\end{array}$ & $\begin{array}{l}91,5 \\
(87,5 ; 95,5) / \\
80,9 \\
(76,1 ; 85,6)\end{array}$ & N/A \\
\hline $\begin{array}{l}\text { Sverige } \\
\text { (2003/cancerregistret) }\end{array}$ & $\mathrm{Ja} / \mathrm{Nej}^{\mathrm{j}}$ & $\begin{array}{l}86,7 \\
(84,8 ; 88,6)\end{array}$ & $\begin{array}{l}92,9 \\
(90,7 ; 95.0) / \\
86,1 \\
(83,2 ; 89,1)\end{array}$ & $\mathrm{N} / \mathrm{A}$ \\
\hline
\end{tabular}

Status pr. juli 2010; ${ }^{\nabla}$ Data ikke systematisk indsamlet, da indikatorerne ikke blev inkluderet i projektet, men da oplysningerne er tilgængelige for 2 lande, er de inkluderet.; ${ }^{y}$ Oplysningerne er ikke koblet til dødsårsagsregister.

Bemærkninger:

De 5 største nordiske lande har enten et klinisk register og/eller kliniske retningslinjer. Operation for melanom er en relativ simpel operation og opgørelsen af 30 dages dødelighed for det ene land, der har leveret tal, viser også en meget lav dødelighed efter 30 dage. Der kan i dette lys sættes spørgsmålstegn ved relevansen af indikatoren. Ligesom det bør reovervejes at inkludere 5 års overlevelsen, som fremgår af indeværende tabel trods, at indikatoren blev udeladt af projektet, for de lande, der på trods heraf har valgt at levere data. Den relative 5 års overlevelse i Sverige, Norge og Danmark er meget ens, men det skal bemærkes, at de dækker forskellige opgørelsesår og dermed ikke er fuld sammenlignelige.

\subsubsection{Tyktarmskræeft - begrundelse for valg af område}

Kræft i tyk- og endetarm (incl. anus og analkanalen) er den 3. mest hyppige cancerform for både mænd og kvinder. Overlevelsen er steget betydeligt verden over (OECD), men der er forskning, der peger på, at screenings- og behandlingsmulighederne fortsat ikke bliver udnyttet i fuld grad, og det er derfor relevant at følge evt. forskelle i behandlingsresultatet. 
Tabel 2.2.6.6.1 Tyktarmskræft - basisindikatorer

\begin{tabular}{|c|c|c|c|c|c|}
\hline $\begin{array}{l}\text { Land } \\
\text { (årstal- } \\
\text { /datakilde) }\end{array}$ & Incidensrate & $\begin{array}{l}\text { Alderstandar- } \\
\text { diseret } \\
\text { incidensrate }\end{array}$ & Prævalensrate & $\begin{array}{l}\text { Mortalitet, } \\
\text { crude }\end{array}$ & $\begin{array}{l}\text { Mortalitet, } \\
\text { alderstandar- } \\
\text { diseret }\end{array}$ \\
\hline & $\begin{array}{l}\text { Kvinderl } \\
\text { Mænd } \\
\text { rate pr. } \\
100.000\end{array}$ & $\begin{array}{l}\text { Kvinderl } \\
\text { Mænd } \\
\text { rate pr. } \\
100.000\end{array}$ & $\begin{array}{l}\text { Kvinderl } \\
\text { Mænd } \\
\text { rate pr. } \\
100.000\end{array}$ & $\begin{array}{l}\text { Kvinder- } \\
\text { IMænd } \\
\text { rate pr. } \\
100.000\end{array}$ & $\begin{array}{l}\text { Kvinder } \\
\text { /Mænd } \\
\text { rate pr. } \\
100.000\end{array}$ \\
\hline $\begin{array}{l}\text { Danmark } \\
\text { (2007/ } \\
\text { NORDCAN) }\end{array}$ & $47,8 / 45,8$ & $43 / 51,6$ & $248 / 267$ & $\begin{array}{l}27,9 / 26,0 \\
N / A\end{array}$ & $\begin{array}{l}24,5 / 32,0 \\
N / A\end{array}$ \\
\hline $\begin{array}{l}\text { Finland } \\
\text { (2007/ } \\
\text { NORDCAN) }\end{array}$ & $30,4 / 28,3$ & $25,1 / 31,6$ & $267 / 283$ & $\begin{array}{l}12,8 / 11,8 \\
\text { N/A }\end{array}$ & $\begin{array}{l}10,3 / 15,0 \\
\text { N/A }\end{array}$ \\
\hline $\begin{array}{l}\text { Færøerne } \\
\text { (2006/ } \\
\text { NORDCAN) }\end{array}$ & N/A & N/A & N/A & $\begin{array}{l}12,9 / 27,9 \\
\text { N/A }\end{array}$ & $\begin{array}{l}14,6 / 32,8 \\
\text { N/A }\end{array}$ \\
\hline $\begin{array}{l}\text { Grønland } \\
\text { (2007/Dep. } \\
\text { for sundhed) }\end{array}$ & $20,0 / 20,0$ & N/A & N/A & $\begin{array}{l}37,5 / 16 \\
7 / 26,5\end{array}$ & N/A \\
\hline $\begin{array}{l}\text { Island } \\
\text { (2006-2008/ } \\
\text { NORDCAN) }\end{array}$ & $29,4 / 37,8$ & $34,9 / 53,9$ & $190 / 206^{\nabla}$ & $\begin{array}{l}13,1 / 14,1 \\
\text { N/A }\end{array}$ & $\begin{array}{l}15,3 / 21,6 \\
\text { N/A }\end{array}$ \\
\hline $\begin{array}{l}\text { Norge } \\
\text { (2007/ } \\
\text { NORDCAN) }\end{array}$ & $51 / 44,2$ & $47,1 / 53$ & $219 / 317$ & $\begin{array}{l}26,6 / 23,0 \\
N / A\end{array}$ & $\begin{array}{l}23,2 / 28,4 \\
\text { N/A }\end{array}$ \\
\hline $\begin{array}{l}\text { Sverige } \\
(2007 / \\
\text { NORDCAN) }\end{array}$ & $41,6 / 38,3$ & $34,5 / 38,7$ & $339 / 347$ & $\begin{array}{l}21,7 / 18,3 \\
\text { N/A }\end{array}$ & $\begin{array}{l}16,8 / 19,0 \\
\text { N/A }\end{array}$ \\
\hline
\end{tabular}

Tallene dækker 2006; ${ }^{\nabla}$ Tallet dækker alene 2007

Bemærkninger:

Incidens af kræft i endetarm i de nordiske lande ligger mellem hhv. 25,1 kvinder/31,6 mænd og 47,1 kvinder/53,9 mænd pr. 100.000 (nordisk standardpopulation). Dermed er der relativ stor variation mellem de nordiske lande i incidensen. Tilsvarende variation kan ses i prævalensen. Mortalitetsraterne viser forskelle i mortaliteten, hvor Danmarks mortalitet er ca. 2,5 gange højere end Finlands. Der er ikke entydig sammenhæng mellem variationen i inciden/prævalens hhv. mortalitet, men det kræver adgang til udvikling i resultater over tid at vurdere, hvad årsagerne er til de respektive tal. 
Tabel 2.2.6.6.2 Tyktarmskræft - kvalitetsindikatorer

\begin{tabular}{|c|c|c|c|c|c|}
\hline $\begin{array}{l}\text { Land (årstal- } \\
\text { /datakilde) }\end{array}$ & $\begin{array}{l}\text { Nationalt } \\
\text { klinisk } \\
\text { registerl } \\
\text { kliniske } \\
\text { retnings- } \\
\text { linjer }\end{array}$ & $\begin{array}{l}\text { Eksisterer der } \\
\text { et nationalt } \\
\text { screenings- } \\
\text { program på } \\
\text { området? } \\
\text { procentdel, der } \\
\text { er screenet }\end{array}$ & $\begin{array}{l}5 \text { års observe- } \\
\text { ret overlevelse } \\
\text { (procentdel, der } \\
\text { overlever det } 5 . \\
\text { år efter diagno- } \\
\text { setidspunktet) } \\
\text { (Cl) } \\
\text { Kvinder/Mænd }\end{array}$ & $\begin{array}{l}5 \text { års relativ } \\
\text { overlevelse, \% } \\
\text { (Cl) } \\
\text { Kvinder/Mænd }\end{array}$ & $\begin{array}{l}30 \text { dages } \\
\text { dødelighed } \\
\text { efter operation, } \\
\text { procentdel død } \\
30 \text { dage efter } \\
\text { operationen } \\
\text { (Cl) } \\
\text { Kvinder/Mænd }\end{array}$ \\
\hline $\begin{array}{l}\text { Danmark } \\
\text { (2002/OECD) }\end{array}$ & $\mathrm{Ja} / \mathrm{Ja}$ & $\begin{array}{l}\text { Nej/ikke } \\
\text { relevant }\end{array}$ & $\begin{array}{l}46,0 \\
(42,0 ; 49,0)^{\nabla v}\end{array}$ & $\begin{array}{l}54,8 \\
(48,1 ; 61,6) / \\
54,2 \\
(47,6 ; 60,7)^{v}\end{array}$ & N/A \\
\hline $\begin{array}{l}\text { Finland } \\
\text { (2003/cancer- } \\
\text { registret 2007, } \\
\text { Finland) }\end{array}$ & $\mathrm{Nej} / \mathrm{Nej}$ & $\begin{array}{l}\text { Pilotprojekt } \\
\text { for screening } \\
\text { iværksat/70 \% } \\
\text { screenet i } \\
\text { pilotområdet }\end{array}$ & $50(\mathrm{~N} / \mathrm{A})^{\nabla}$ & $61(N / A)^{\nabla}$ & $2,1(N / A)^{\nabla J}$ \\
\hline Færøerne & $\mathrm{Nej} / \mathrm{Nej}$ & $\begin{array}{l}\text { Nej/ikke } \\
\text { relevant }\end{array}$ & N/A & N/A & N/A \\
\hline Grønland & $\mathrm{Nej} / \mathrm{Nej}^{-1}$ & $\begin{array}{l}\text { Nej/ikke } \\
\text { relevant }\end{array}$ & N/A & N/A & N/A \\
\hline $\begin{array}{l}\text { Island } \\
\left(2003 /^{\Delta}\right.\end{array}$ & $\mathrm{Ja} / \mathrm{Nej}^{\square}$ & $\begin{array}{l}\text { Nej/ikke } \\
\text { relevant }\end{array}$ & 62 (NA) & 72 (NA) & N/A \\
\hline $\begin{array}{l}\text { Norge } \\
\left(2001 /^{\Delta}\right.\end{array}$ & $\mathrm{Ja} / \mathrm{Ja}$ & $\begin{array}{l}\text { Nej/ikke } \\
\text { relevant }\end{array}$ & $\begin{array}{l}48,2(43,1 ; \\
53,2) / 61,4 \\
(57,5 ; 65,3)\end{array}$ & $\begin{array}{l}60,8 \\
(58,0 ; 63,6)^{\nabla}\end{array}$ & N/A \\
\hline $\begin{array}{l}\text { Sverige } \\
\text { (2004/cancer- } \\
\text { registret) }\end{array}$ & $\mathrm{Ja} / \mathrm{Ja}$ & $\begin{array}{l}\text { Nej/ikke } \\
\text { relevant }\end{array}$ & $\begin{array}{l}55,7(53,0 ; \\
58,3) / 50,8 \\
(48,3 ; 53,3)\end{array}$ & $\begin{array}{l}63,2 \\
(60,3 ; 66,0) / \\
60,6 \\
(57,6 ; 63,5)\end{array}$ & $\begin{array}{l}\text { Elektivt opere- } \\
\text { rede: } \\
2,4(\mathrm{~N} / \mathrm{A})^{\nabla t} \\
\text { Akut operere- } \\
\text { de: } 9,1(\mathrm{~N} / \mathrm{A})^{\nabla \mathrm{t}}\end{array}$ \\
\hline
\end{tabular}

Status pr. juli 2010. *Kliniske retningslinjer under udarbejdelse (publiceres dec. 2010), 'Datakilde: Svensk kvalitetsregister, dækker patienter opereret i 2008; ${ }^{\nabla}$ Dækker begge køn. ${ }^{\vee} D æ k k e r$ både colon og rektumcancer; kan ikke sammenlignes med opdelte resultater. ${ }^{\mathrm{J}}$ Patienter opereret i 2008; ${ }^{\wedge}$ Nomesko temasektion om kvalitetsindikatorer (upubliceret)). ${ }^{1}$. Danske retningslinier tilpasset lokale forhold bruges

Bemærkninger:

30 dages dødelighed er alene opgjort for Finland (samlet for begge køn) og Sverige, og disse tal giver ikke mulighed for meningsfuld sammenligning og fortolkning; på baggrund af de svenske resultater, der viser den store forskel i dødelighed for hhv. akut hhv. elektivt opererede, må det anbefales, at denne indikator overvejes opdelt i forhold til de 2 grupper. Denne fremgangsmåde vil også svare til den anvendte i f.eks. det danske kvalitetsregister.

5 års overlevelsen er opgjort i varierende grad for hhv. begge køn, flere kræftformer og forskellige år, så der er ikke belæg for at drage klare konklusioner. Hvis der bliver adgang til data for mere sammenlignelige perioder/større årrække bør der være fokus på, om tendensen til, at overlevelsen i Danmark er lavere end de andre landes, kan fastholdes. 


\subsubsection{Endetarmskrceft - begrundelse for valg af område}

Se begrundelse for valg af tyktarmskræft.

Tabel 2.2.6.7.1 Endetarmskræft - basisindikatorer

\begin{tabular}{|c|c|c|c|c|c|}
\hline $\begin{array}{l}\text { Land (årstal- } \\
\text { /datakilde) }\end{array}$ & Incidensrate & $\begin{array}{l}\text { Alders- } \\
\text { standardise- } \\
\text { ret incidens- } \\
\text { rate }\end{array}$ & $\begin{array}{l}\text { Prævalens- } \\
\text { rate }\end{array}$ & $\begin{array}{l}\text { Mortalitet, } \\
\text { crude }\end{array}$ & $\begin{array}{l}\text { Mortalitet, } \\
\text { alderstan- } \\
\text { dardiseret }\end{array}$ \\
\hline & $\begin{array}{l}\text { Kvinder- } \\
\text { IMænd } \\
\text { rate pr. } \\
100.000\end{array}$ & $\begin{array}{l}\text { Kvinder- } \\
\text { IMænd } \\
\text { rate pr. } \\
100.000\end{array}$ & $\begin{array}{l}\text { Kvinder- } \\
\text { IMænd } \\
\text { rate pr. } \\
100.000\end{array}$ & $\begin{array}{l}\text { Kvinder- } \\
\text { IMænd } \\
\text { rate pr. } \\
100.000\end{array}$ & $\begin{array}{l}\text { Kvinder- } \\
\text { IMænd } \\
\text { rate pr. } \\
100.000\end{array}$ \\
\hline $\begin{array}{l}\text { Danmark (2007I } \\
\text { NORDCAN) }\end{array}$ & $23,9 / 32,7$ & $21,8 / 35,2$ & $155 / 223$ & $\begin{array}{l}10,0 / 12,5 \\
N / A^{\square}\end{array}$ & $\begin{array}{l}8,8 / 15,2 \\
N / A\end{array}$ \\
\hline $\begin{array}{l}\text { Finland ( } 2007 / \\
\text { NORDCAN) }\end{array}$ & $16,2 / 21,1$ & $13,5 / 22,4$ & $106 / 152$ & $6,7 / 8,8$ N/A & $\begin{array}{l}5,4 / 10,1 \\
\text { N/A }\end{array}$ \\
\hline $\begin{array}{l}\text { Færøerne (2006/ } \\
\text { NORDCAN) }\end{array}$ & N/A & N/A & N/A & $\begin{array}{l}4,3 / 19,9 \\
\text { N/A }\end{array}$ & $\begin{array}{l}3,5 / 28,0 \\
\text { N/A }\end{array}$ \\
\hline $\begin{array}{l}\text { Grønland (2007/ } \\
\text { Dep. for sundhed) }\end{array}$ & $13,3 / 15,0$ & N/A & N/A & $3,7 / 0 / 1,8$ & N/A \\
\hline $\begin{array}{l}\text { Island (2006-2008/ } \\
\text { NORDCAN) }\end{array}$ & $12,4 / 12,6$ & $14,3 / 17,1$ & $109 / 140^{\nabla}$ & $2,0 / 2,3 \mathrm{~N} / \mathrm{A}$ & $2,2 / 3,4 \mathrm{~N} / \mathrm{A}$ \\
\hline $\begin{array}{l}\text { Norge (2007I } \\
\text { NORDCAN) }\end{array}$ & $21,2 / 26,2$ & $20,2 / 30$ & $178 / 238$ & $\begin{array}{l}7,7 / 10,1 \\
\text { N/A }\end{array}$ & $\begin{array}{l}6,6 / 12,2 \\
N / A\end{array}$ \\
\hline $\begin{array}{l}\text { Sverige (2007I } \\
\text { NORDCAN) }\end{array}$ & $20,7 / 25,8$ & $17,2 / 25,8$ & $132 / 175$ & $8,0 / 9,9 \mathrm{~N} / \mathrm{A}$ & $\begin{array}{l}6,3 / 10,1 \\
\text { N/A }\end{array}$ \\
\hline
\end{tabular}

Tallene dækker 2006; ${ }^{\nabla}$ Tallet dækker alene 2007

Bemærkninger:

Incidens af kræft i endetarm i de nordiske lande ligger mellem hhv. 13,5 kvinder/17,1 mænd og 21,8 kvinder/35,2 mænd pr. 100.000 (nordisk standardpopulation). Dvs. incidensen for kvinder er relativ ensartet på tværs af de nordiske lande, mens der er betydelig variation i forhold til mænd, hvor Norge og Danmarks er markant højere. Ift. prævalensen ses også ganske markant variation. Den justerede mortalitetsrate i 2006 svinger ganske markant både mellem lande og køn. Danmark har en relativ høj mortalitet, og Island en relativ lav mortalitet i forhold til denne sygdom. 
Tabel 2.2.6.7.2 Endetarmskræft - kvalitetsindikatorer

\begin{tabular}{|c|c|c|c|c|c|}
\hline $\begin{array}{l}\text { Land (årstal- } \\
\text { /datakilde) }\end{array}$ & $\begin{array}{l}\text { Nationalt } \\
\text { klinisk regi- } \\
\text { ster/kliniske } \\
\text { retningslinjer }\end{array}$ & $\begin{array}{l}\text { Eksisterer der } \\
\text { et nationalt } \\
\text { screenings- } \\
\text { program på } \\
\text { området? } \\
\text { procentdel, der } \\
\text { er screenet }\end{array}$ & $\begin{array}{l}5 \text { års observe- } \\
\text { ret overlevelse } \\
\text { (procentdel, } \\
\text { der overlever } \\
\text { det } 5 . \text { år efter } \\
\text { diagnosetids- } \\
\text { punktet) (Cl) }\end{array}$ & $\begin{array}{l}5 \text { års relativ } \\
\text { overlevelse, \% } \\
\text { (Cl) }\end{array}$ & $\begin{array}{l}30 \text { dages } \\
\text { dødelighed } \\
\text { efter operation, } \\
\text { procentdel død } \\
30 \text { dage efter } \\
\text { operationen } \\
\text { (Cl) }\end{array}$ \\
\hline & & & Kvinder/Mænd & $\begin{array}{l}\text { Kvinder/Mænd } \\
\text { i alt }\end{array}$ & $\begin{array}{l}\text { Kvinder/Mænd } \\
\text { i alt }\end{array}$ \\
\hline $\begin{array}{l}\text { Danmark } \\
\text { (OECD, } \\
2002)\end{array}$ & $\mathrm{Ja} / \mathrm{Ja}$ & $\begin{array}{l}\text { Nej/ikke } \\
\text { relevant }^{\square}\end{array}$ & $\begin{array}{l}46,0(42,0 ; \\
49,0)^{\nabla v}\end{array}$ & $\begin{array}{l}54,8 \\
(48,1 ; 61,6) / \\
54,2 \\
(47,6 ; 60,7)^{v}\end{array}$ & $\mathrm{~N} / \mathrm{A}$ \\
\hline $\begin{array}{l}\text { Finland } \\
\text { (2003/cancer } \\
\text {-registret } \\
2007 \text {, } \\
\text { Finland) }\end{array}$ & $\mathrm{Nej} / \mathrm{Nej}$ & $\begin{array}{l}\text { Pilotprojekt } \\
\text { for screening } \\
\text { iværksat/70 } \\
\% \text { screenet i } \\
\text { pilotområdet }\end{array}$ & $49(\mathrm{~N} / \mathrm{A})^{\nabla}$ & $59(N / A)^{\nabla}$ & $2,0(N / A)^{\nabla J}$ \\
\hline Færøerne & $\mathrm{Nej} / \mathrm{Nej}$ & $\begin{array}{l}\text { Nej/ikke } \\
\text { relevant }\end{array}$ & $\mathrm{N} / \mathrm{A}$ & $\mathrm{N} / \mathrm{A}$ & N/A \\
\hline Grønland & $\mathrm{Nej} / \mathrm{Nej}^{-1}$ & $\begin{array}{l}\text { Nej/ikke } \\
\text { relevant }\end{array}$ & N/A & N/A & N/A \\
\hline $\begin{array}{l}\text { Island } \\
\left(2003 /^{\Delta}\right.\end{array}$ & $\mathrm{Ja} / \mathrm{Nej}^{\square}$ & $\begin{array}{l}\text { Nej/ikke } \\
\text { relevant }\end{array}$ & 62 (NA) & 72 (NA) & $\mathrm{N} / \mathrm{A}$ \\
\hline $\begin{array}{l}\text { Norge } \\
\left(2001 /^{\Delta}\right.\end{array}$ & $\mathrm{Ja} / \mathrm{Ja}$ & $\begin{array}{l}\text { Nej/ikke } \\
\text { relevant }\end{array}$ & $\begin{array}{l}56,8( \\
46,5 ; 67,2) / \\
49.5 \\
(40,1 ; 58,9)\end{array}$ & $\begin{array}{l}71,7 \\
(65,6 ; 77,8) / \\
63,0 \\
(57,3 ; 68.7)\end{array}$ & $\mathrm{N} / \mathrm{A}$ \\
\hline $\begin{array}{l}\text { Sverige } \\
\text { (2004/, } \\
\text { cancer- } \\
\text { registret) }\end{array}$ & $\mathrm{Ja} / \mathrm{Ja}$ & $\begin{array}{l}\text { Nej/ikke } \\
\text { relevant }\end{array}$ & $\begin{array}{l}58,8 \\
(55,5 ; 62,2) / \\
50,7 \\
(47,7 ; 53,7)\end{array}$ & $\begin{array}{l}65,5 \\
(61,7 ; 69,3) / \\
58,5 \\
(54,9 ; 62,0)\end{array}$ & $1,2 / 2,9^{t}$ \\
\hline
\end{tabular}

Status pr. juli 2010. *Kliniske retningslinjer under udarbejdelse (publiceres dec. 2010), 'Datakilde: Svensk kvalitetsregister, dækker patienter opereret i 2009; ${ }^{\nabla}$ Dækker begge køn. ${ }^{\vee D æ k k e r ~ b a ̊ d e ~ c o l o n ~ o g ~ r e k t u m c a n c e r ; ~ k a n ~ i k k e ~}$ sammenlignes med opdelte resultater; ${ }^{\mathrm{J}}$ Patienter opereret i 2008.; ${ }^{\Delta}$ Nomesko temasektion om kvalitetsindikatorer (upubliceret)).

${ }^{1}$. Danske retningslinier tilpasset lokaleforhold bruges

Bemærkninger:

5 års overlevelsen for Island er trods usikkerheden højere end resten af de nordiske lande (for begge køn er opnået relativ overlevelse på 72 \%). Samtidig har Island en forholdsvis lav prævalens, incidens og mortalitet i forhold til patienter med endetarmskræft. Forskellene er så markante, at det må formodes, at det skyldes forskelle i patientsammensætningen evt. forskelle i livstilsfaktorer.

30 dages dødelighed er alene opgjort for Finland (samlet begge køn) og Sverige, og disse tal giver ikke mulighed for meningsfuld sammenligning og fortolkning. 
Tabel 2.2.6.8 Potentielle indikatorer vedrørende kræftsygdomme

\begin{tabular}{|c|c|}
\hline Indikatornavn & Definitioner \\
\hline Tyktarmskræft & Kvalitetsindikatorer \\
\hline $\begin{array}{l}\text { ICD } 10 \text { - Diagno- } \\
\text { sekode: } \\
\text { C18 }\end{array}$ & $\begin{array}{l}\text { Der bør udvikles fælles nordiske indikatorer der belyser, om patienten får den rette } \\
\text { diagnostik og behandling i overensstemmelse med nationale kliniske retningslinjer } \\
\text { Ventetid } \\
\text { Tid fra kontakt til intervention } \\
\text { Hospitals delay } \\
\text { Doctors delay } \\
\text { Patients delay } \\
\text { Kvalitet i palliativ pleje og behandling } \\
\text { Komplikationer } \\
\text { Reoperationer } \\
\text { Recidiv } \\
\text { Overlevelse i relation til diagnose og intervention } \\
\text { Resultat af intervention } \\
\text { Livskvalitet }\end{array}$ \\
\hline Endetarmskræft & Kvalitetsindikatorer \\
\hline $\begin{array}{l}\text { ICD } 10 \text { - Diagno- } \\
\text { sekode: } \\
\text { C21-22 }\end{array}$ & $\begin{array}{l}\text { Der bør udvikles fælles nordiske indikatorer der belyser, om patienten får den rette } \\
\text { diagnostik og behandling i overensstemmelse med nationale kliniske retningslinjer } \\
\text { Ventetid } \\
\text { Tid fra kontakt til intervention } \\
\text { Hospitals delay } \\
\text { Doctors delay } \\
\text { Patients delay } \\
\text { Kvalitet i palliativ pleje og behandling } \\
\text { Komplikationer } \\
\text { Reoperationer } \\
\text { Recidiv } \\
\text { Overlevelse i relation til diagnose og intervention } \\
\text { Resultat af intervention } \\
\text { Livskvalitet }\end{array}$ \\
\hline Lungekræft & Kvalitetsindikatorer \\
\hline $\begin{array}{l}\text { ICD } 10 \text { - Diagno- } \\
\text { sekode: } \\
\text { C33-34a }\end{array}$ & $\begin{array}{l}\text { Der bør udvikles fælles nordiske indikatorer der belyser, om patienten får den rette } \\
\text { diagnostik og behandling i overensstemmelse med nationale kliniske retningslinjer } \\
\text { Ventetid } \\
\text { Tid fra kontakt til intervention } \\
\text { Hospitals delay } \\
\text { Doctors delay } \\
\text { Patients delay } \\
\text { Kvalitet i palliativ pleje og behandling } \\
\text { Komplikationer } \\
\text { Reoperationer } \\
\text { Recidiv } \\
\text { Overlevelse i relation til diagnose og intervention } \\
\text { Resultat af intervention } \\
\text { Livskvalitet }\end{array}$ \\
\hline
\end{tabular}




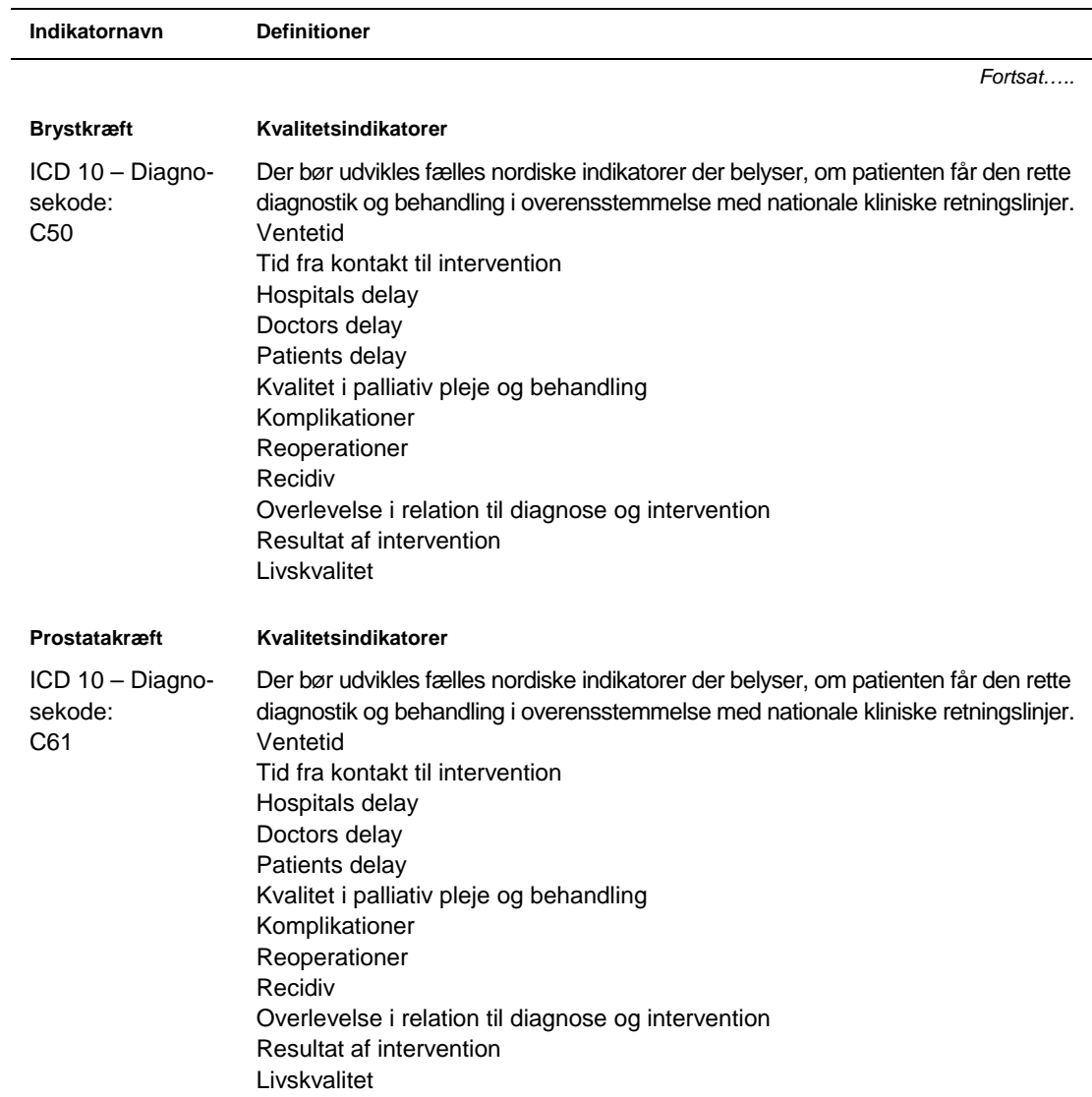

Livmoderhalskræft

ICD10 -

Diagnosekode: C53

\section{Kvalitetsindikatorer}

Der bør udvikles fælles nordiske indikatorer der belyser, om patienten får den rette diagnostik og behandling i overensstemmelse med nationale kliniske retningslinjer. Ventetid

Tid fra kontakt til intervention

Hospitals delay

Doctors delay

Patients delay

Kvalitet i palliativ pleje og behandling

Komplikationer

Reoperationer

Recidiv

Overlevelse i relation til diagnose og intervention

Resultat af intervention

Livskvalitet 


\begin{tabular}{ll}
\hline Indikatornavn & Definitioner \\
\hline Melanom & Kvalitetsindikatorer \\
ICD 10- Diagno- & Der bør udvikles fælles nordiske indikatorer der belyser, om patienten får den rette \\
sekode: & diagnostik og behandling i overensstemmelse med nationale kliniske retningslinjer. \\
C43 & Ventetid \\
& Tid fra kontakt til intervention \\
& Hospitals delay \\
& Doctors delay \\
& Patients delay \\
& Kvalitet i palliativ pleje og behandling \\
& Komplikationer \\
& Reoperationer \\
& Recidiv \\
& Overlevelse i relation til diagnose og intervention \\
& Resultat af intervention \\
& Livskvalitet \\
\hline
\end{tabular}

\subsubsection{Hjerte/karsygdomme}

Nedenfor er opgjort resultater for henholdsvis basis- og kvalitetsindikatorer for følgende hjerte/karsygdomme:

- Blodprop i hjertet (AMI)

- Apopleksi/stroke (hhv. blødning i hjernen og blodprop i hjernen).

Begrundelse for valg af de respektive områder fremgår af de enkelte dataafsnit.

\subsubsection{Blodprop i hjertet (AMI) - begrundelse for valg}

Hjertekarsygdomme er fortsat den hyppigste årsag til død i industrialiserede lande, trods at dødeligheden er faldet siden 1970'erne. Faldet i dødelighed kan hænge sammen med bedre akut behandling i forhold til AMI (3), men der er behov for yderligere analyse for at forklare forskelle over tid og mellem regioner(4). 
Tabel 2.2.7.1.1 Blodprop i hjertet (AMI) - basisindikatorer

\begin{tabular}{|c|c|c|c|}
\hline \multirow[t]{3}{*}{ Land (årstal/datakilde) } & Incidensrate & $\begin{array}{l}\text { Alderstandardiseret } \\
\text { incidensrate }\end{array}$ & $\begin{array}{l}\text { Mortalitet, antal der dør } \\
\text { af blodprop pr. } 100.000 \\
\text { indbyggere }\end{array}$ \\
\hline & $\begin{array}{l}\text { Kvinder/Mænd } \\
\text { rate pr. } 100.000\end{array}$ & $\begin{array}{l}\text { Kvinder/Mænd } \\
\text { rate pr. } 100.000\end{array}$ & $\begin{array}{l}\text { Alderstandardiseret } \\
\text { Kvinder/Mænd* }^{*}\end{array}$ \\
\hline & $\begin{array}{l}\text { Patienter med kontakt } \\
\text { med behandlings- } \\
\text { væsenet }\end{array}$ & $\begin{array}{l}\text { Patienter med kontakt } \\
\text { med behandlings- } \\
\text { væsenet }\end{array}$ & \\
\hline $\begin{array}{l}\text { Danmark } \\
\text { (2007/Nomesko) }\end{array}$ & $125 / 222^{*}$ & $\mathrm{~N} / \mathrm{A}$ & N/A \\
\hline $\begin{array}{l}\text { Finland } \\
\text { (2007/Nomesko) }\end{array}$ & $\begin{array}{l}141 / 215^{\star} \\
159,8^{g}\end{array}$ & N/A & N/A \\
\hline $\begin{array}{l}\text { Færøerne } \\
\text { (2007/Nomesko) }\end{array}$ & $\begin{array}{l}113 / 230^{*} \\
202^{t}\end{array}$ & $\mathrm{~N} / \mathrm{A}$ & N/A \\
\hline $\begin{array}{l}\text { Grønland (2007/ Dep. } \\
\text { for sundhed) }\end{array}$ & $54,7^{\mathrm{j}}$ & N/A & N/A \\
\hline $\begin{array}{l}\text { Island } \\
\text { (2007/Nomesko) }\end{array}$ & $79 / 195^{*}$ & N/A & N/A \\
\hline $\begin{array}{l}\text { Norge } \\
(2007 /)\end{array}$ & $237 / 467^{*}$ & N/A & N/A \\
\hline $\begin{array}{l}\text { Sverige } \\
\text { (2007/patientregistret) }\end{array}$ & $212,8 / 314,2$ & $207,6 / 398,7$ & $63,8^{\prime} 123,7^{\nabla}$ \\
\hline
\end{tabular}

*Dækker antal behandlet for AMI pr. 100.000 og er dermed ikke udtryk for incidensen, da også prævalente er i behandling. opgjort ift. pr. person - dvs. personer med flere sygdomstilfælde tælles kun én gang; ${ }^{\nabla}$ Det svenske dødsårsagsregister. ${ }^{9}$ Opgjort samlet for 2009 for begge køn, kilde: det finske udskrivningsregister; *indikatoren er ikke formelt inkluderet i indikatorsamlingen, men ét enkelt land har leveret data. 'Samlet for begge køn, patientregisteret i Færøerne 5-års gennemsnit 2004-2008. ${ }^{j}$. Opgjort samlet for begge køn

Bemærkninger:

Valg af basisindikatorer ift. AMI er vanskelig, da det er en sygdom, der er kendetegnet ved, at det varierer i hvor høj grad, patienterne kommer i hospitalsbehandling, ligesom dødsårsagen ikke kan forventes registreret korrekt i alle tilfælde. I forbindelse hermed blev basisindikatoren mortalitet i første omgang udeladt, men data for det ene land, der har leveret dem er vist i indeværende tabel. Incidensraten, som her er opgjort ift. patienter i kontakt med hospitalvæsenet og som jf. note $\left(^{*}\right)$ er behæftet med usikkerhed, viser i den rå rate nogen variation, hvor især Norges afviger ganske meget, men da der ikke er adgang til alderstandardiserede rater, kan der ikke konkluderes endeligt. Det anbefales, at mulighederne for at opgøre retvisende til stadighed undersøges. 
Tabel 2.2.7.1.2 Blodprop i hjertet (AMI) - kvalitetsindikatorer

\begin{tabular}{|c|c|c|}
\hline $\begin{array}{l}\text { Land (årstal- } \\
\text { /datakilde) }\end{array}$ & $\begin{array}{l}\text { Nationalt klinisk register/kliniske } \\
\text { retningslinjer }\end{array}$ & $\begin{array}{l}30 \text { dages dødelighed for patienter behand- } \\
\text { let for AMI (dødsfald på hospital)* } \\
\text { (Cl) } \\
\text { Alders- og kønstandardiseret }\end{array}$ \\
\hline $\begin{array}{l}\text { Danmark } \\
(2007 / O E C D)\end{array}$ & $\mathrm{Nej} / \mathrm{Ja}$ & $2,9(\mathrm{~N} / \mathrm{A})$ \\
\hline $\begin{array}{l}\text { Finland } \\
\text { (2007/OECD) }\end{array}$ & $\mathrm{Nej} / \mathrm{Ja}$ & 4,9 (N/A) \\
\hline Færøerne & $\mathrm{Nej} / \mathrm{Nej}$ & $(N / A)^{g}$ \\
\hline Grønland & $\mathrm{Nej} / \mathrm{Nej}^{{ }^{1}}$ & $(\mathrm{~N} / \mathrm{A})$ \\
\hline $\begin{array}{l}\text { Island } \\
(2007 / O E C D)\end{array}$ & $\mathrm{Ja} / \mathrm{Ja}$ & 2,1 (N/A) \\
\hline $\begin{array}{l}\text { Norge } \\
(2007 / O E C D)\end{array}$ & $\mathrm{Nej} / \mathrm{Nej}^{\circledR}$ & 3,2 (N/A) \\
\hline $\begin{array}{l}\text { Sverige } \\
(2007 / O E C D)\end{array}$ & $\mathrm{Ja} / \mathrm{Ja}$ & $2,9(\mathrm{~N} / \mathrm{A})$ \\
\hline
\end{tabular}

Status pr. juli 2010; ' I andet regi oplyses, at Norge har retningslinjer, som omhandler primærforebyggelsen. ${ }^{9}$ Færøerne oplyser, at deres rå 30 dages dødelighed (in-hospital) er $8 \%$ samlet for begge køn, men dette resultat er ikke sammenligneligt med de standardiserede resultater for de andre lande. *Denne indikator var planlagt opgjort hhv. baseret på indlæggelser/patientbaseret som i forhold til hhv. dødsfald på samme hospital som behandlet: dødsfald på ethvert hospital: dødsfald uanset sted. Da det ikke har været muligt at indsamle disse oplysninger for alle lande er der i stedet valgt at tage udgangspunkt i den indlæggelsesbaserede opgørelse i OECD, Health at a Glance for at sikre sammenligneligheden. ${ }^{1}$ Danske retningslinier tilpasset lokale forhold bruges

Bemærkninger:

Af de nordiske lande er det kun Island og Sverige, der har nationale kliniske register.

30 dages dødeligheden er inden for samme niveau i de nordiske lande, bortset fra at der er en tendens til, at Finlands ligger på et højere niveau; uden adgang til oplysninger om konfidenstintervaller og resultater over tid, bør der ikke konkluderes på forskellene.

\subsubsection{Apopleksi/stroke - blodprop i hjernen (iskcmisk apopleksi) - begrundelse for valg}

Apopleksi er den tredje hyppigste årsag til død og nedsat førlighed i de industrialiserede lande (WHO, 2002). Det vurderes, at omkring 2-4 \% af sundhedsudgifterne bruges til patienter med apopleksi, ligesom der er betydelige udgifter forbundet med genoptræning.

Behandlingsmuligheder i forhold til blodprop i hjernen er øget betydeligt over de seneste år. Indførelseshastigheden i forhold til disse behandlingsmuligheder kan formodes at påvirke case-fatality og prævalensen af sygdommen. 
Tabel 2.2.7.2.1 Apopleksi - blodprop i hjernen - basisindikatorer

\begin{tabular}{|c|c|c|c|}
\hline \multirow[t]{4}{*}{ Land (årstal/datakilde) } & \multirow[t]{2}{*}{ Incidensrate } & \multirow[t]{2}{*}{$\begin{array}{l}\text { Alderstandardiseret } \\
\text { incidensrate }\end{array}$} & \multirow{4}{*}{$\begin{array}{l}\text { Mortalitet, antal der dør af } \\
\text { blodprop i hjernen pr. } \\
100.000 \text { indbyggere } \\
\text { Alderstandardiseret } \\
\text { Kvinder/Mænd* }\end{array}$} \\
\hline & & & \\
\hline & Kvinder/Mænd & Kvinder/Mænd & \\
\hline & rate pr. 100.000 & rate pr. 100.000 & \\
\hline Danmark & N/A & N/A & N/A \\
\hline $\begin{array}{l}\text { Finland } \\
\text { (2008/patientregistret) }\end{array}$ & $172,0^{t}$ & N/A & N/A \\
\hline $\begin{array}{l}\text { Færøerne } \\
\text { (2004-08 } \\
\text { /patientregistreret) }\end{array}$ & 123,0 & N/A & N/A \\
\hline $\begin{array}{l}\text { Grønland (2007/Dep. } \\
\text { for sundhed) }\end{array}$ & $22,9^{f}$ & N/A & N/A \\
\hline Island & N/A & N/A & N/A \\
\hline $\begin{array}{l}\text { Norge } \\
(2007 /)\end{array}$ & N/A & N/A & N/A \\
\hline $\begin{array}{l}\text { Sverige } \\
\text { (2007/patientregistret) }\end{array}$ & $222,8 / 227,3$ & $190,3 / 270,7$ & $52,7 / 59,8^{\nabla}$ \\
\hline
\end{tabular}

opgjort ift. pr. person - dvs. personer med flere sygdomstilfælde tælles kun én gang; ${ }^{\nabla}$ Det svenske dødsårsagsregister opgjort samlet for blodprop i hjernen/hjerneblødning. 'Opgjort samlet for 2009 for begge køn; *indikatoren er ikke formelt inkluderet i indikatorsamlingen, men ét enkelt land har leveret data. ${ }^{\mathrm{f}} \mathrm{Hvis}$ patienter kodet med diagnosen 164 (slagtilfælde uden oplysning om blødning eller infarkt) inddrages, er incidensraten 185,3.

Bemærkninger:

Kun ganske få lande har kunnet levere data vedr. basisindikatorerne for blodprop i hjernen, og der kan ikke konkluderes meningsfuldt på data. 
Tabel 2.2.7.2.2 Apopleksi - blodprop i hjernen - kvalitetsindikatorer

\begin{tabular}{|c|c|c|}
\hline $\begin{array}{l}\text { Land (årstal- } \\
\text { /datakilde) }\end{array}$ & $\begin{array}{l}\text { Nationalt klinisk register/kliniske } \\
\text { retningslinjer }\end{array}$ & $\begin{array}{l}30 \text { dages dødelighed for patienter behand- } \\
\text { let for blodprop i hjernen (dødsfald på } \\
\text { hospital)* } \\
\text { (Cl) } \\
\text { Alder- og kønsstandardiseret }\end{array}$ \\
\hline $\begin{array}{l}\text { Danmark } \\
\text { (2007/OECD) }\end{array}$ & $\mathrm{Ja} / \mathrm{Ja}$ & $3,1(\mathrm{~N} / \mathrm{A})$ \\
\hline $\begin{array}{l}\text { Finland } \\
\text { (2007/OECD) }\end{array}$ & $\mathrm{Ja} / \mathrm{Ja}$ & 3,2 (N/A) \\
\hline Færøerne & $\mathrm{Ja} / \mathrm{Nej}$ & $(\mathrm{N} / \mathrm{A})$ \\
\hline Grønland & $\mathrm{Nej} / \mathrm{Nej}^{\square 1}$ & $(\mathrm{~N} / \mathrm{A})$ \\
\hline $\begin{array}{l}\text { Island } \\
(2007 / O E C D)\end{array}$ & $\mathrm{Nej} / \mathrm{Ja}$ & $2,3(\mathrm{~N} / \mathrm{A})$ \\
\hline $\begin{array}{l}\text { Norge } \\
(2007 / O E C D)\end{array}$ & $\mathrm{Ja} / \mathrm{Ja}$ & 3,3 (N/A) \\
\hline $\begin{array}{l}\text { Sverige } \\
(2007 / O E C D)\end{array}$ & $\mathrm{Ja} / \mathrm{Ja}$ & 3,9 (N/A) \\
\hline
\end{tabular}

Status pr. juli 2010; *Denne indikator var planlagt opgjort hhv. baseret på indlæggelser/patientbaseret som i forhold til hhv. dødsfald på samme hospital som behandlet: dødsfald på ethvert hospital: dødsfald uanset sted. Da det ikke har været muligt at indsamle disse oplysninger for alle lande, er der i stedet valgt at tage udgangspunkt i den indlæggelsesbaserede opgørelse i OECD, Health at a Glance for at sikre sammenligneligheden. ${ }^{9} \mathrm{~F}$ ærøerne oplyser, at deres rå 30 dages dødelighed (in-hospital) er $13 \%$ samlet for begge køn, men dette resultat er ikke sammenligneligt med de standardiserede resultater for de andre lande. ${ }^{1}$ Danske retningslinier tilpasset lokale forhold bruges.

Bemærkninger:

Alle nordiske lande undtaget Grønland har enten kliniske registre og/eller kliniske retningslinjer. 30 dages dødeligheden er inden for samme niveau i de nordiske lande, bortset fra at der er en tendens til, at Islands ligger på et lavere niveau; uden adgang til oplysninger om konfidenstintervaller og resultater over tid bør der ikke konkluderes på forskellene.

Data for dødelighed stammer fra OECD og er i høj grad baseret på patientadministrative data - data fra det danske kliniske register viser rå dødelighed noget over niveauet i OECD (rå rater ikke vist i indeværende rapport), hvor der skal tages højde for, at den også dækker dødsfald efter udskrivning. Andre studier viser, at patientadministrative systemer ikke er velegnet til identifikation af patienter med apopleksi (5). På baggrund af dette i kombination med en beregnet dødelighed lavere end i de kliniske registre betyder, at det fremover anbefales, at afrapportering af data fra patientadministrative registre så vidt muligt kombineres med oplysninger fra kliniske registre.

Det er bemærkelsesværdigt at lande, hvor 30 dages dødelighed for blodprop i hjernen ligger højt, har en relativ lav dødelighed for hjerneblødning. Det bør overvejes, om det skyldes forskelle i kodningspraksis. Tallenes afhængighed af kodepraksis ses også illustreret af Grønlands resultater vedrørende incidens og de store ændringer ved inklusion af koden 164 (Slagtilfælde uden oplysning om blødning eller infarkt) jf. note (f) i tabel 2.2.7.2.1 - hvor disse tal naturligvis også bærer præg af Grønlands lille befolkningstal. 
2.2.7.3 Apopleksi/stroke - hjerneblødning (hcemorrhagi) - begrundelse for valg

Se begrundelse for valg af apopleksi/stroke - blodprop i hjernen.

Tabel 2.2.7.3.1 Apopleksi - hjerneblødning - basisindikatorer

\begin{tabular}{|c|c|c|c|}
\hline \multirow[t]{3}{*}{ Land (årstal/datakilde) } & \multirow{3}{*}{$\begin{array}{l}\text { Incidensrate } \\
\text { Kvinder/Mænd } \\
\text { rate pr. } 100.000\end{array}$} & \multirow{3}{*}{$\begin{array}{l}\text { Alderstandardiseret } \\
\text { incidensrate } \\
\text { Kvinder/Mænd } \\
\text { rate pr. } 100.000\end{array}$} & \multirow{3}{*}{$\begin{array}{l}\text { Mortalitet, antal der dør } \\
\text { af hjerneblødning pr. } \\
100.000 \text { indbyggere } \\
\text { Alderstandardiseret } \\
\text { Kvinder/Mænd* }\end{array}$} \\
\hline & & & \\
\hline & & & \\
\hline Danmark & N/A & N/A & N/A \\
\hline $\begin{array}{l}\text { Finland } \\
\text { (2008/patientregistret) }\end{array}$ & $33,7^{t}$ & N/A & N/A \\
\hline $\begin{array}{l}\text { Færøerne } \\
\text { (2004-8/patientregistret) }\end{array}$ & 123,0 & N/A & N/A \\
\hline $\begin{array}{l}\text { Grønland (2007/Dep. for } \\
\text { sundhed) }\end{array}$ & $31,8^{t}$ & N/A & N/A \\
\hline Island & N/A & N/A & N/A \\
\hline $\begin{array}{l}\text { Norge } \\
(2007 /)\end{array}$ & N/A & N/A & N/A \\
\hline $\begin{array}{l}\text { Sverige } \\
\text { (2007/patientregisret) }\end{array}$ & $32,0 / 37,6$ & $30,1 / 45,8$ & $52,7 / 59,8^{\nabla}$ \\
\hline
\end{tabular}

opgjort ift. pr. person - dvs. personer med flere sygdomstilfælde tælles kun én gang; ${ }^{\nabla}$ Det svenske dødsårsagsregister opgjort samlet for blodprop i hjernen/hjerneblødning. 'Opgjort samlet for 2009 for begge køn; *indikatoren er ikke formelt inkluderet i indikatorsamlingen, men ét enkelt land har leveret data.

Bemærkninger:

Kun ganske få lande har kunnet levere data vedr. basisindikatorerne for hjerneblødning og der kan ikke konkluderes meningsfuldt på data. 
Tabel 2.2.7.3.2 Apopleksi - hjerneblødning - kvalitetsindikatorer

\begin{tabular}{|c|c|c|}
\hline Land (årstal-/datakilde) & $\begin{array}{l}\text { Nationalt klinisk regi- } \\
\text { ster/kliniske retningslinjer }\end{array}$ & $\begin{array}{l}30 \text { dages dødelighed for patienter behandlet } \\
\text { for hjerneblødning (dødsfald på hospital)* } \\
\text { (Cl) } \\
\text { Alder- og kønsstandardiseret }\end{array}$ \\
\hline $\begin{array}{l}\text { Danmark } \\
(2007 / O E C D)\end{array}$ & $\mathrm{Ja} / \mathrm{Ja}$ & $16,7(\mathrm{~N} / \mathrm{A})$ \\
\hline Finland (2007/OECD) & $\mathrm{Ja} / \mathrm{Ja}$ & $9,5(\mathrm{~N} / \mathrm{A})$ \\
\hline Færøerne & $\mathrm{Ja} / \mathrm{Nej}^{\square}$ & $(\mathrm{N} / \mathrm{A})$ \\
\hline Grønland & $\mathrm{Nej} / \mathrm{Nej}^{-1}$ & $(\mathrm{~N} / \mathrm{A})$ \\
\hline Island (2007/OECD) & $\mathrm{Nej} / \mathrm{Ja}$ & $19,8(N / A)$ \\
\hline Norge (2007/OECD) & $\mathrm{Ja} / \mathrm{Ja}$ & $13,7(\mathrm{~N} / \mathrm{A})$ \\
\hline Sverige (2007/OECD) & $\mathrm{Ja} / \mathrm{Ja}$ & $12,8(N / A)$ \\
\hline
\end{tabular}

Status pr. juli 2010;

*Denne indikator var planlagt opgjort hhv. baseret på indlæggelser/patientbaseret som i forhold til hhv. dødsfald på samme hospital som behandlet: dødsfald på ethvert hospital: dødsfald uanset sted. Da det ikke har været muligt at indsamle disse oplysninger for alle lande, er der i stedet valgt at tage udgangspunkt i den indlæggelsesbaserede opgørelse i OECD, Health at a Glance for at sikre sammenligneligheden. ${ }^{9}$ Færøerne oplyser, at deres rå 30 dages dødelighed (in-hospital) er $13 \%$ samlet for begge køn, men dette resultat er ikke sammenligneligt med de standardiserede resultater for de andre lande. ${ }^{1}$ Danske retningslinier tilpasset lokale forhold bruges.

Bemærkninger:

Alle nordiske lande undtaget Grønland har enten kliniske registre og/eller kliniske retningslinjer.

Der er nogen variation i dødeligheden på tværs af de nordiske lande, men det skal bemærkes, at resultaterne er behæftet med usikkerhed, da incidensen for hjerneblødning, er relativ lav. Forskellene kan derfor ikke tolkes meningsfuldt jf. i øvrigt kommentarerne til tabel 2.2.1.2 apopleksi - blodprop i hjernen. 
rigur 2.2.7.2.1 Eksempel på udvikling over tid, Sverige

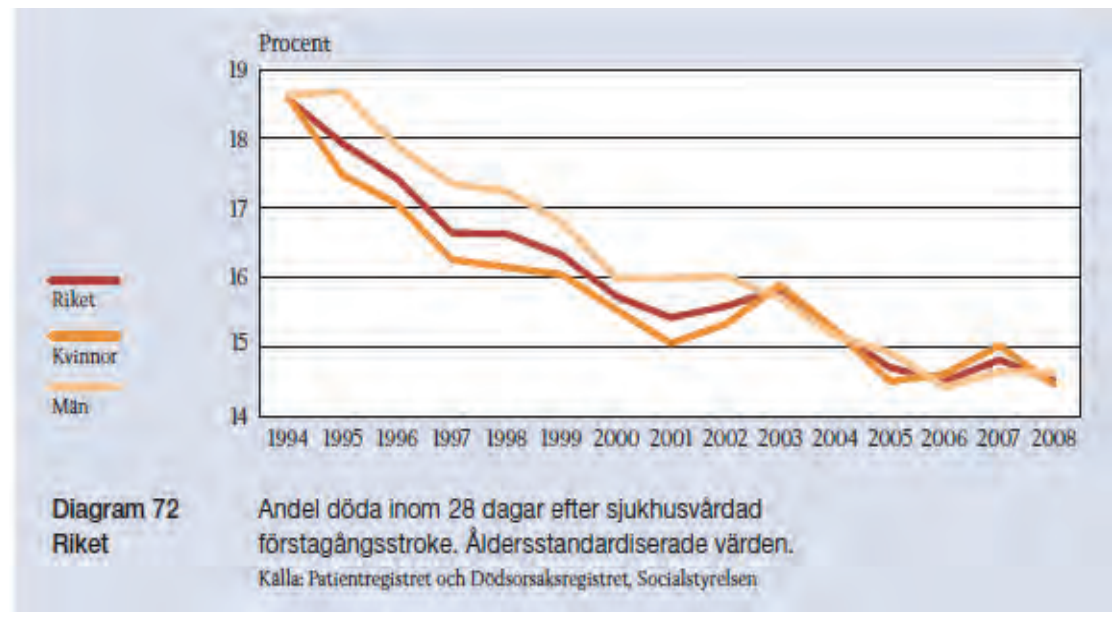

Grafen viser, at stadig ferre dør efter apopleksi og det illustrerer, at data fra forskellige opgørelsesår ikke bør sammenlignes.

Figur 2.2.7.3.1 Eksempel på procesindikatorer - Danmark

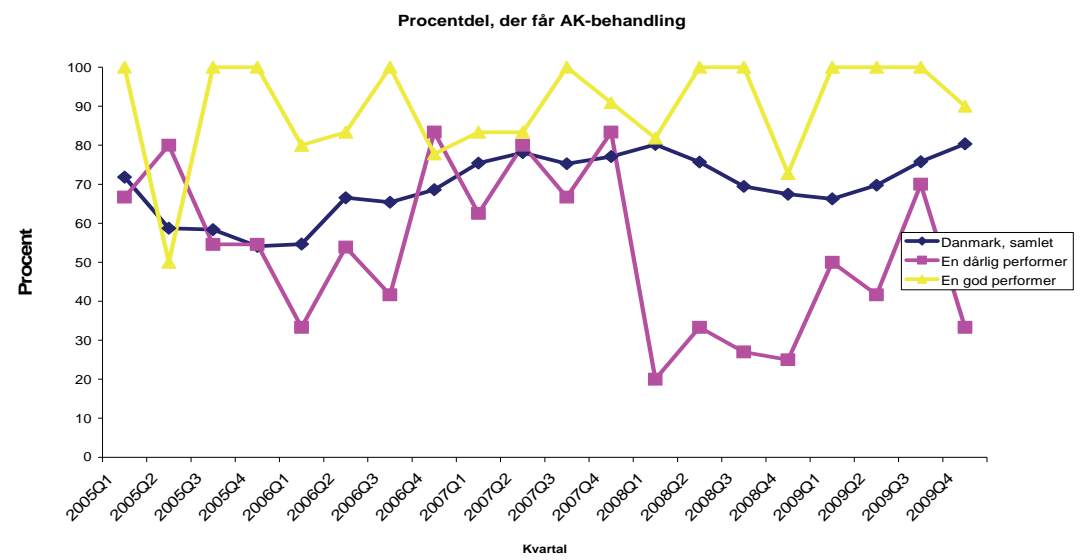

Kilde: Det Nationale Indikatorprojekt.

Prognosen for patienter med apopleksi er stærk afhcengig af hurtig ivcrksættelse af relevant behandling. På denne baggrund er det meget relevant at måle kvaliteten i forhold til procesmål som det f.eks. er gjort i ovenstående graf. Det skal især ses i lyset af, at flere lignende målingerne har vist store forskelle i resultater på tvcers af afdelinger/lande. 
Tabel 2.2.7.4. Potentielle indikatorer vedrørende hjerte-karsygdomme

\begin{tabular}{|c|c|}
\hline Indikatornavn & Definitioner \\
\hline \multirow{11}{*}{$\begin{array}{l}\text { Akut myokardie- } \\
\text { infarkt AMI } \\
\text { ICD } 10- \\
\text { Diagnosekode } \\
\text { DI21 }\end{array}$} & Kvalitetsindikatorer \\
\hline & $\begin{array}{l}\text { Der bør udvikles fælles nordiske indikatorer der belyser, om patienten får den rette } \\
\text { diagnostik og behandling i overensstemmelse med nationale kliniske retningslinjer }\end{array}$ \\
\hline & Tid fra kontakt til intervention \\
\hline & Overlevelse i relation til diagnose og intervention \\
\hline & Resultat af intervention \\
\hline & Eksempler på behandling \\
\hline & $\begin{array}{l}\text { Andelen patienter som vårdats på sjukhus för hjärtinfarkt och som 12-18 månader } \\
\text { efter utskrivningen använder ASA, annan trombocythämmare eller antikoagulantia. } \\
\text { Avser patienter <80 år som vårdats för hjärtinfarkt under 2005-2006. Procent }\end{array}$ \\
\hline & $\begin{array}{l}\text { Andelen patienter som vårdats på sjukhus för hjärtinfarkt och som 12-18 } \\
\text { månader efter utskrivningen använder betablockerare. Avser patienter <80 år } \\
\text { som vårdats för hjärtinfarkt under } 2005-2006 \text {. Procent }\end{array}$ \\
\hline & $\begin{array}{l}\text { Andelen patienter som vårdats på sjukhus för hjärtinfarkt och som 12-18 } \\
\text { månader efter utskrivningen använder lipidsänkare. Avser patienter <80 år } \\
\text { som vårdats för hjärtinfarkt under 2005-2006 }\end{array}$ \\
\hline & Komplikationer \\
\hline & Livskvalitet \\
\hline Indikatornavn & Definitioner \\
\hline \multirow[t]{11}{*}{ Hjertekirurgi } & Kvalitetsindikatorer \\
\hline & Ventetid \\
\hline & Ventetid på PCI foretaget på indikationen stabil angina pectoris \\
\hline & Ventetid på PCI foretaget på indikationen AKS \\
\hline & Tid fra ankomst til sygehus til start af $\mathrm{PCl}$ ved $\mathrm{AMI}$ \\
\hline & Tid fra kontakt til intervention \\
\hline & Andel patienter der får behandling i forhold til diagnose \\
\hline & Overlevelse i relation til diagnose og intervention \\
\hline & Resultat af intervention \\
\hline & Komplikationer \\
\hline & Livskvalitet \\
\hline
\end{tabular}

\section{Apopleksia Cerebri Kvalitetsindikatorer}

ICD 10 Diagnosekode: DI63-64
Der bør udvikles fælles nordiske indikatorer der belyser, om patienten får den rette diagnostik og behandling i overensstemmelse med nationale kliniske retningslinjer Eksempler på indikatorer:

Tid fra kontakt til intervention

Patienter der indlægges i en apopleksienhed, andel

Andel patienter med akut iskæmisk apopleksi og atrieflimren, der sættes i antikoagulansbehandling

Andel patienter med blodprop i hjernen der får thrombolyserende behandling indenfor 3 timer

Andel patienter, der får udført CT/MR scanning

Andel strokepatienter med blodtrykssænkende behandling

Andel strokepatienter med blodfedtsænkende behandling 


\begin{tabular}{ll}
\hline Indikatornavn & Definitioner \\
\hline & Overlevelse i relation til diagnose og intervention \\
& Resultat af intervention \\
& Komplikationer \\
& Livskvalitet \\
Hypertension & Kvalitetsindikatorer \\
ICD 10- & $\begin{array}{l}\text { Der bør udvikles fælles nordiske indikatorer der belyser, om patienten får den } \\
\text { Diagnosekode: } \\
\text { I10.9 }\end{array}$ \\
& rette diagnostik og behandling i overensstemmelse med nationale kliniske \\
& Hypertension admission rate (OECD-indikator) \\
& $\begin{array}{l}\text { Patienter med hypertension, der er i behandling ifølge kliniske retningslinier } \\
\text { (evidence based clinical guidelines), andel } \\
\text { Overlevelse i relation til diagnose og intervention } \\
\text { Resultat af intervention } \\
\text { Komplikationer }\end{array}$ \\
\hline
\end{tabular}

\subsubsection{Kroniske sygdomme}

Nedenfor er opgjort resultater for hhv. basis- og kvalitetsindikatorer for de følgende kroniske sygdomme:

- Astma

- Diabetes

a) herunder specifikke resultater alene for børn og unge med diabetes.

Begrundelse for valg af de respektive områder fremgår af de enkelte dataafsnit.

2.2.8.1 Astma - begrundelse for valg

Astma er den hyppigste kroniske sygdom blandt børn og prævalensen har været kraftigt stigende, hvor den i nogle industrialiserede lande er fordoblet på 30 år. 
Tabel 2.2.8.1.1 Astma - basis og kvalitetsindikatorer

\begin{tabular}{|c|c|c|c|}
\hline Land (årstal/datakilde) & $\begin{array}{l}\text { Akutte indlæggelser/ alle } \\
\text { indlæggelsse pr. } 100.000 \\
\text { indbyggere } \\
\text { Alders- og kønstandardi- } \\
\text { seret }\end{array}$ & $\begin{array}{l}\text { Mortalitetsrate, antal } \\
\text { pr. } 100.000 \text { indbygge- } \\
\text { re, der dør af astma } \\
\text { Alders standardiseret } \\
\text { Kvinder/Mænd } \\
\text { (udelukkende syge- } \\
\text { husindlagte) }\end{array}$ & $\begin{array}{l}\text { Nationalt } \\
\text { klinisk regi- } \\
\text { ster/kliniske } \\
\text { retningslinjer }\end{array}$ \\
\hline $\begin{array}{l}\text { Danmark } \\
(2007 / O E C D)\end{array}$ & $(N / A) / 43^{\nabla}$ & $0,05 / 0,05$ & \\
\hline $\begin{array}{l}\text { Finland } \\
(2007 / O E C D)\end{array}$ & $(\mathrm{N} / \mathrm{A}) / 92^{\nabla}$ & $0 / 0$ & $\mathrm{Ja} / \mathrm{Ja}$ \\
\hline $\begin{array}{l}\text { Færøerne } \\
\text { (2004-08/patientregistret) }\end{array}$ & $93 /(N / A)$ & N/A & $\mathrm{Nej} / \mathrm{Nej}$ \\
\hline $\begin{array}{l}\text { Grønland (2007/Dep. for } \\
\text { sundhed) }\end{array}$ & $(\mathrm{N} / \mathrm{A})$ & 0 & $\mathrm{Nej} / \mathrm{Nej}^{1}$ \\
\hline $\begin{array}{l}\text { Island } \\
(2007 / O E C D)\end{array}$ & $(\mathrm{N} / \mathrm{A}) / 34^{\nabla f}$ & $0,18 / 0,09$ & $\mathrm{Nej} / \mathrm{Ja}$ \\
\hline $\begin{array}{l}\text { Norge } \\
(2007 / O E C D)\end{array}$ & $(\mathrm{N} / \mathrm{A}) / 42^{\nabla}$ & $0,18 / 0,0$ & $\mathrm{Nej} / \mathrm{Nej}$ \\
\hline $\begin{array}{l}\text { Sverige } \\
(2007 / O E C D)\end{array}$ & $(\mathrm{N} / \mathrm{A}) / 25^{\nabla}$ & $0,08 / 0,08$ & $\mathrm{Ja} / \mathrm{Ja}$ \\
\hline
\end{tabular}

${ }^{\nabla}$ opgjort for patienter over 15 år; 'Finland har desuden opgjort en rate for indlæggelse på 262 med udskrivningsregistret; den store forskel mellem dette tal og tallet afrapporteret i regi af OECD kunne tyde på, at der er mulighed for forskellige fortolkninger af denne indikator, og på denne baggrund skal anbefales, at der i fremtidige afrapporteringer sikres entydige definitioner af tæller/nævner. ${ }^{1}$ Danske retningslinier tilpasset lokale forhold bruges.

Bemærkninger:

Det absolutte antal dødsfald pga. astma i de nordiske lande er så lavt, at resultaterne ikke giver mulighed for at konstatere eventuelle kvalitetsforskelle eller drage konklusioner.

Kun Færøerne har opgjort antal akutte indlæggelser pr. 100.000 indbyggere - i modsætning til data for alle indlæggelser fra de andre lande, så har Færøerne derudover ikke ekskluderet patienter under 15 år, og dette tal bør derfor ikke sammenlignes med resultaterne for alle indlæggelser for de andre lande.

Det er muligt at undgå langt hovedparten af indlægelser pga. astma og antallet af indlægelser bør derfor være meget lavt (OECD, Health at a Glance, 2009, s. 116), Generelt er der nogle forskelle i antallet af akutte indlæggelser, men uden data om incidensen/prævalensen er det ikke muligt at konstatere, om disse er udtryk for forskelle i behandlingskvaliteten.

\subsubsection{Diabetes - begrundelse for valg}

Diabetes - såvel type 1 som type 2 - er i kraftig vækst i hele den industrialiserede verden. Behandlingskvaliteten har afgørende betydning for udviklingen af sendiabetiske komplikationer, hvor der er udviklet gode behandlingsmeto- 
der. Med korrekt behandling kan overdødeligheden blandt diabetikere således nedbringes og det er derfor væsentlig, at behandlingskvaliteten monitoreres.

Tabel 2.2.8.2.1 diabetes - basisindikatorer

\begin{tabular}{lll}
\hline Land (årstal/datakilde) & $\begin{array}{l}\text { Procentdel af befolkningen, } \\
\text { der har diabetes (20-79 årige) }\end{array}$ & $\begin{array}{l}\text { Incidensrate pr. 100.000 indbyg- } \\
\text { gere (kun børn under 15 år) }\end{array}$ \\
\hline $\begin{array}{l}\text { Danmark } \\
\text { (2010, the International Diabe- } \\
\text { tes Federation) }\end{array}$ & $7,7^{\mathrm{L}}$ & $22.2^{\mathrm{L}}$ \\
$\begin{array}{l}\text { Finland } \\
\text { (2010, the International Diabe- } \\
\text { tes Federation) }\end{array}$ & 8,3 & 57,4 \\
$\begin{array}{l}\text { Færøerne } \\
\text { Grønland (2009/Dep. for }\end{array}$ & $\mathrm{N} / \mathrm{A}$ & $62,1^{\mathrm{T}}$ \\
sundhed) & 1,8 & $\mathrm{~N} / \mathrm{A}$ \\
$\begin{array}{l}\text { Island } \\
\text { (2010, the International Diabe- } \\
\text { tes Federation) }\end{array}$ & 8,3 & 0 \\
$\begin{array}{l}\text { Norge } \\
\text { (2010, the International Diabe- } \\
\text { tes Federation) }\end{array}$ & 4,7 & 14,7 \\
$\begin{array}{l}\text { Sverige } \\
\text { (2009/Svenska läkemedelsre- } \\
\text { gistret, Socialstyrelsen) }\end{array}$ & $7,3^{\mathrm{g}}$ & \\
\hline
\end{tabular}

jOpgjort for 2008; 'Svenska läkemedelsregistret, Socialstyrelsen, opgjort for 2008; ${ }^{9} 2010$, the International Diabetes Federation; 'inkluderer Grønland; ' Folkpensionsanstalten: statistik över läkemedel och ersättningsrättigheter 2008. Der er omkring 10 børn med Diabetes.

Bemærkninger:

Alene Sverige har kunnet levere tal for prævalens/incidens, og derfor er der i stedet løftet tal fra the International Diabetes Federation - disse tal er udtryk for estimater, og jf. forskellen i Sveriges egenrapporterede tal for prævalens og tallet fra the International Diabetes Federation bør de fortolkes med forsigtighed. Umiddelbart ser det ud til, at incidensraterne er mere identiske på tværs af kilder. 
Tabel 2.2.8.2.2. diabetes - kvalitetsindikatorer

\begin{tabular}{|c|c|c|c|c|c|}
\hline $\begin{array}{l}\text { Land (årstal- } \\
\text { /datakilde) }\end{array}$ & $\begin{array}{l}\text { Nationalt } \\
\text { klinisk } \\
\text { regi- } \\
\text { ster/kliniske } \\
\text { retningslinjer }\end{array}$ & $\begin{array}{l}\text { Procentdel af } \\
\text { patienter } \\
\text { med diabe- } \\
\text { tes, der får } \\
\text { årlig øjenun- } \\
\text { dersøgelse }\end{array}$ & $\begin{array}{l}\text { Procentdel af } \\
\text { patienter } \\
\text { med diabe- } \\
\text { tes, der } \\
\text { uplanlagt } \\
\text { indlægges }\end{array}$ & $\begin{array}{l}\text { Antal pr. } \\
100.000 \\
\text { indbyggere, } \\
\text { der hhv. } \\
\text { underben- } \\
\text { sampute- } \\
\text { res/amputere } \\
\text { s over fodled }\end{array}$ & $\begin{array}{l}\text { Antal pr. } \\
100.000 \\
\text { indbyggere, } \\
\text { der indlæg- } \\
\text { ges pga. } \\
\text { komplikatio- } \\
\text { ner (short- } \\
\text { term) } \\
\text { (Cl) }\end{array}$ \\
\hline $\begin{array}{l}\text { Danmark } \\
(2007 / O E C D)\end{array}$ & $\mathrm{Ja} / \mathrm{Ja}$ & Ca. $83 \%^{h}$ & N/A & $21 / \mathrm{N} / \mathrm{A}$ & $20(18 ; 21)$ \\
\hline $\begin{array}{l}\text { Finland } \\
\text { (2008/udskrivnings- } \\
\text { registret) }\end{array}$ & $\mathrm{Ja} / \mathrm{Ja}$ & N/A & 7 & $11^{\mathrm{J}} /(\mathrm{N} / \mathrm{A})^{\mathrm{v}}$ & $31(30 ; 33)^{\star}$ \\
\hline Færøerne & NejNej & N/A & N/A & N/A/ N/A & N/A \\
\hline $\begin{array}{l}\text { Grønland } \\
\text { (2009/Dep. for } \\
\text { sundhed }\end{array}$ & $\begin{array}{l}\text { For børn og } \\
\text { unge } \\
\text { Nej/Nej } \\
\text { For voksne } \\
\text { under op- } \\
\text { bygning/Ja }\end{array}$ & $N / A^{b}$ & N/A & N/A/ N/A & N/A \\
\hline $\begin{array}{l}\text { Island } \\
(2007 / O E C D)\end{array}$ & NejJa & N/A & N/A & N/A/ N/A & $10(6 ; 14)$ \\
\hline $\begin{array}{l}\text { Norge } \\
\text { (2007/OECD) }\end{array}$ & $\mathrm{Ja} / \mathrm{Ja}$ & N/A & N/A & $11 / \mathrm{N} / \mathrm{A}$ & $20(19 ; 22)$ \\
\hline Sverige & $\mathrm{Ja} / \mathrm{Ja}$ & Ca. $90 \%{ }^{g}$ & N/A & $12 / 4$ & $19(18 ; 20)$ \\
\hline
\end{tabular}

Status pr. juli 2010; ${ }^{9}$ det svenske nationale diabetesregister, 2009; ${ }^{\mathrm{J} O E C D}, 2007$ - Finland har også opgjort data på basis af et ad hoc diabetesregister. Dette tal er på 1800 pr. 100.000, hvilket må antages at være baseret på en anden beregningsmetode, måske antal pr. 100.000 diabetikere; " Finland har også opgjort data på basis af et ad hoc diabetesregister. Dette tal er på $0,4 \%$ - pga. tvivl om basispopulation jf. note ${ }^{\mathrm{j}}$ kan dette tal dog ikke fortolkes. ${ }^{\mathrm{h}}$ Det nationale indikatorprojekt, patienter behandlet 2008-2009. ${ }^{\star} \mathrm{OECD}, 2007 .{ }^{\mathrm{y}} \mathrm{Nej}$, men alle følges af samme børnelæge. ${ }^{1}$ Danske retningslinier tilpasset lokale forhold bruges.

Bemærkninger:

Alle nordiske lande undtagen Færøerne har kliniske retningslinjer og/eller nationalt register for diabetesområdet. Det er ikke oplyst, om der er selvstændige retningslinjer/registre for børn og unge, så det er ikke muligt at afrapportere opdelt i forhold til dette. Det var ellers intentionen, at inkluderer disse oplysninger.

Alle lande har for ét eller flere områder ikke kunnet levere data, og der kan derfor ikke konkluderes meningsfuldt på hovedparten af kvalitetsindikatorerne. Der er valide opgørelser for antallet, der indlægges pga. komplikationer af deres diabetes, og her viser resultaterne, at der er en markant større andel af patienter, der indlægges pga. senkomplikationer i Finland end resten af de nordiske lande. Resultaterne for Danmark, Sverige og Norge ligger på samme niveau, mens Island har en signifikant mindre andel, der får komplikationer. Disse forskelle er ikke umiddelbart betinget af forskelle i prævalensraterne (jf. i tabel 2.2.8.2.1, kolonne 2), men taget de meget forskellige incidensrater i betragtning, bør resultaterne tolkes med forsigtighed. 


\begin{tabular}{lll}
$\begin{array}{l}\text { Tabel 2.2.8.2.3 diabetes - kvalitetsindikatorer - særligt rettet mod børn og unge } \\
\text { (under 18 år) }\end{array}$ & $\begin{array}{l}\text { Procentdel af børn og unge } \\
\text { med diabetes, hvor HbA1c er } \\
\text { under 7,0\% }\end{array}$ & $\begin{array}{l}\text { Antal sygehusophold pr. 1000 } \\
\text { børn/unge for hhv. hypoglykæmi } \\
\text { /ketoacidose }\end{array}$ \\
\hline $\begin{array}{ll}\text { Land (årstal-/datakilde) } \\
\text { Danmark }\end{array}$ & N/A & N/A \\
Finland & N/A & $0,08 / 0,22$ \\
Færøerne & N/A & N/A \\
Grønland & N/A & N/A \\
Island & N/A & N/A \\
Norge & N/A & N/A \\
$\begin{array}{l}\text { Sverige } \\
\text { (2008/SweDiabKids, 2009) }\end{array}$ & 29 & $0,03 / 0,12^{\mathrm{v}}$ \\
\hline
\end{tabular}

kilde: SweDiabKids, 2009 - dækker patienter med HbA1c under 6,5\%; 'Dansk Register for Børne- og Ungdoms Diabetes (2007/8) har opgjort procentdelen af børn \& unge med diabetes, der får hypoglykæmi til ca. 9 \% i 2008, tilsvarende andel med ketoacidose er ca. $2 \%$. Resultaterne kan ikke umiddelbart omregnes til andel af befolkningen og er ikke sammenlignelige med den faktiske indikator; ${ }^{\vee}$ Svenska patientregistret, Socialstyrelsen.

Bemærkninger:

Det har ikke været muligt systematisk at opgøre de 3 indikatorer, som skulle give mulighed for at vurdere behandlingskvaliteten specifikt for børn- og unge. Der kan derfor ikke konkluderes noget entydigt om kvaliteten. 
Tabel 2.2.8.3 Potentielle indikatorer vedrørende kroniske sygdomme

\begin{tabular}{|c|c|}
\hline Indikatornavn & Definitioner \\
\hline Astma & Kvalitetsindikatorer \\
\hline $\begin{array}{l}\text { ICD } 10 \text { - } \\
\text { Diagnosekode: } \\
\text { J45-46 }\end{array}$ & $\begin{array}{l}\text { Der bør udvikles fælles nordiske indikatorer der belyser, om patienten får den rette } \\
\text { diagnostik og behandling i overensstemmelse med nationale kliniske retningslinjer } \\
\text { Eksempler på indikatorer: } \\
\text { Tid fra kontakt til intervention } \\
\text { Overlevelse i relation til diagnose og intervention } \\
\text { Resultat af intervention } \\
\text { Komplikationer } \\
\text { Livskvalitet }\end{array}$ \\
\hline $\begin{array}{l}\text { Diabetes } \\
\text { Mellitus } \\
\text { ICD } 10 \text { - } \\
\text { Diagnosekode: } \\
\text { E10-11, E14 }\end{array}$ & 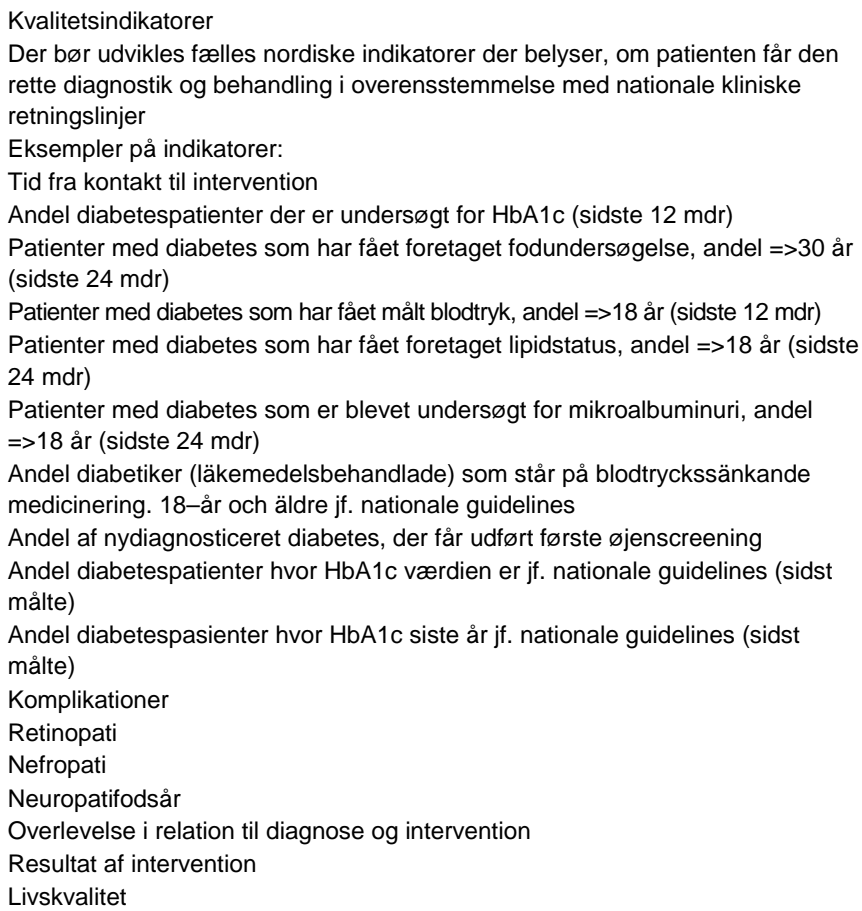 \\
\hline
\end{tabular}

\subsubsection{Graviditet og fødsel}

Nedenfor er opgjort resultater for flg. områder inden for graviditets- og fødselsområdet:

- Aborter

- Kejsersnit

- Mortalitet (perinatal) 
- Rygning

- Amning

- Barns tilstand.

\subsubsection{Begrundelse for valg af område}

Selvom fødsler må betragtes som normale fænomener, udgør omsorg for mor og barn et stort og væsentligt indsatsområde i de nordiske sundhedsvæsner, og området indgår derfor i indeværende publikation. Praktisk talt alle fødsler foregår under medvirken af autoriserede sundhedspersoner og langt størstedelen i forbindelse med hospitalisering. Selvom både børne- og mødredødelighed er lav, medfører fødselsforløbet enten behov for interventioner af operativ karakter eller udvikling af lettere komplikationer hos mor og barn i over halvdelen af alle fødsler (6). Der ses her store geografiske variationer i hyppighed - også inden for det nordiske område, samtidig med at der her eksisterer data af relativ høj validitet.

Tabel 2.2.9.1.1 Graviditet og fødsel - aborter per 1000 kvinder fordelt på alder

\begin{tabular}{llllllll}
\hline & $\mathbf{1 5 - 1 9}$ år & $\mathbf{2 0 - 2 4}$ år & $\mathbf{2 5 - 2 9}$ år & $\mathbf{3 0 - 3 4}$ år & $\mathbf{3 5 - 3 9}$ år & $\mathbf{4 0 - 4 4}$ år & $\mathbf{4 5 - 4 9 ~ a ̊ r ~}$ \\
\hline Danmark (2009) & $16,4^{1}$ & $24,8^{1}$ & $18,7^{1}$ & $16,9^{1}$ & $12,9^{1}$ & $5.0^{1}$ & $0,5^{1}$ \\
Finland (2007) & $13,4^{2}$ & $18,0^{2}$ & $12,7^{2}$ & $10,2^{2}$ & $7,6^{2}$ & $3,0^{2}$ & $0,2^{2}$ \\
Færøerne (2007) & $4,8^{2}$ & $11,6^{2}$ & $3,4^{2}$ & $4,3^{2}$ & $4,5^{2}$ & $3,7^{2}$ & $0.0^{2}$ \\
Grønland (2007) & $101,5^{2}$ & $138,0^{2}$ & $108,1^{2}$ & $63,2^{2}$ & $23,3^{2}$ & $8,3^{2}$ & $0,9^{2}$ \\
Island (2007) & $17,7^{2}$ & $22,3^{2}$ & $17,0^{2}$ & $10,7^{2}$ & $9,8^{2}$ & $2,4^{2}$ & $0,1^{2}$ \\
Norge (2007) & $17,0^{2}$ & $29,5^{2}$ & $22,4^{2}$ & $15,9^{2}$ & $11,2^{2}$ & $4,2^{2}$ & $0,4^{2}$ \\
Sverige (2009) & $22,0^{3}$ & $33,4^{3}$ & $26,3^{3}$ & $21,1^{3}$ & $16,1^{3}$ & $6,9^{3}$ & $0,8^{3}$ \\
\hline
\end{tabular}

Kilde: ${ }^{1}$ Det medicinske fødselsregister 2009. Danmarks statistiks middelfolketal 2009. ${ }^{2}$ Health Statistics in the Nordic Countries 2007. ${ }^{3}$ Svensk abortstatistik, Sverige

Bemærkninger

Raterne for aborter svinger mellem de nordiske lande, hvor Grønlands resultater er markant forskellige fra resten af de nordiske lande. 
Tabel 2.2.9.1. 2 Graviditet og fødsel - aborter (metode)

\begin{tabular}{|c|c|c|c|c|}
\hline & $\begin{array}{l}\text { Aborter } \\
\text { pr. } 1000 \text { levende- } \\
\text { fødte }\end{array}$ & $\begin{array}{l}\text { Procentdel af } \\
\text { aborter før niende } \\
\text { uge foretaget } \\
\text { hhv. medicinsk } \\
\text { og kirurgisk }\end{array}$ & $\begin{array}{l}\text { Andel evacuerede } \\
\text { efter medicinsk } \\
\text { behandling }\end{array}$ & $\begin{array}{l}\text { Andel re- } \\
\text { evacuerede } \\
\text { efter kirurgisk } \\
\text { behandling }\end{array}$ \\
\hline $\begin{array}{l}\text { Danmark (2009) } \\
\text { *2008 }\end{array}$ & $256,6^{1}$ & $64,4 / 35,6^{1}$ & $5,5^{*}$ & 1,9 * \\
\hline $\begin{array}{l}\text { Finland } \\
\nabla(2007) *(2008)\end{array}$ & $179,4^{\nabla 2}$ & $86,4 / 13,6^{* 3}$ & $2,5^{\left\llcorner^{3}\right.}$ & $0,5^{\lrcorner^{3}}$ \\
\hline $\begin{array}{l}\text { Færøerne } \\
\nabla(2007) *(2008)\end{array}$ & $68,0^{\nabla 2}$ & N/A & N/A & N/A \\
\hline Grønland (2007) & 1068 & N/A & $\mathrm{N} / \mathrm{A}$ & N/A \\
\hline Island (2008) & $198,1^{6}$ & N/A & N/A & N/A \\
\hline $\begin{array}{l}\text { Norge } \\
\nabla(2007) *(2008)\end{array}$ & $260,0^{\nabla 2}$ & N/A & N/A & $\mathrm{N} / \mathrm{A}$ \\
\hline $\begin{array}{l}\text { Sverige } \\
\nabla(2009) *(2008)\end{array}$ & $335,2^{\vee 9}$ & $66,5 / 11,2^{\nabla 9 t}$ & N/A & N/A \\
\hline
\end{tabular}

Kilde: ${ }^{1}$ Abortregistret 2009+2008+Landspatientregistret 2008. ${ }^{2}$ Health Statistics in the Nordic Countries 2007. ${ }^{3} \mathrm{THL}$ Abortregister 2008. ${ }^{6}$ Directorate of Health and Statistics Iceland. ${ }^{7}$ The Icelandic Birth Registration, National University Hospital, Dept. of Obstetrics \& Gynecology; Statistics Iceland. ${ }^{9}$ Svensk abortstatistik, Sverige. I I modsætning til de andre lande har Sverige ikke opgjort indikatoren ud af det samlede antal provokerede aborter før ni uger.

Bemærkninger:

Der er ganske betydelige forskelle i indikatorresultaterne - men der er også klare forskelle i opgørelsesmetoder, der illustrerer behovet for at sikre entydige definitioner af indikatorerne forud for en endelig fortolkning af data.

Kun 2 lande har kunnet opgøre resultater vedr. evacuerede, og resultaterne kan dermed ikke fortolkes meningsfuldt. 
Tabel 2.2.9.1.3 Graviditet og fødsel - kejsersnit

\begin{tabular}{llll}
\hline & $\begin{array}{l}\text { Procentdel af } \\
\text { fødsler, der sker } \\
\text { ved kejsersnit }\end{array}$ & $\begin{array}{l}\text { Procentdel af } \\
\text { fødsler, der sker ved } \\
\text { elektivt kejsersnit }\end{array}$ & $\begin{array}{l}\text { Procentdel af } \\
\text { fødsler, der sker } \\
\text { ved akut kejsersnit }\end{array}$ \\
\hline Danmark (2009) & $21,7^{1}$ & $10,2^{1}$ & $11,6^{1}$ \\
Finland ${ }^{\nabla}(2007) *(2008)$ & $16,7^{* 4}$ & $6,6^{* 4}$ & $10,1^{* 4}$ \\
Færøerne ${ }^{\nabla}(2007) *(2008)$ & $19,0^{* 5}$ & $\mathrm{~N} / \mathrm{A}$ & $\mathrm{N} / \mathrm{A}$ \\
Grønland (2008/Dep. for sundhed) & 9,8 & 3,2 & 6,6 \\
Island $(2008)$ & $16,4^{7}$ & $\mathrm{~N} / \mathrm{A}$ & $\mathrm{N} / \mathrm{A}$ \\
Norge $^{\nabla}(2007) *(2008)$ & $17,1^{8}$ & $39,5^{8^{*}}$ & $54,5^{8 *}$ \\
Sverige $^{\nabla}(2009) *(2008)$ & $17,2^{* 9}$ & $8,3^{* 9}$ & $8,7^{* 9}$ \\
\hline
\end{tabular}

Kilde: ${ }^{1}$ Det medicinske Fødselsrgister $2009{ }^{4} \mathrm{THL}$ Födelseregister 2008. ${ }^{5}$ Sundhedsberetning for Færøerne 2008.

${ }^{7}$ The Icelandic Birth Registration, National University Hospital, Dept. of Obstetrics \& Gynecology; Statistics Iceland.

${ }^{8}$ Medisinsk fødselsregister, Norge. ${ }^{9}$ Svensk födelseregister. *Givet at de opgjorte procentdele af fødsler, der sker ved kejsersnit er mindre end summen af procentdelene af hhv. akut og planlagte kejsersnit, må det konstateres, at Norge ikke har beregnet tallene i forhold til samme population - og at tallene derfor ikke er sammenlignelige med de resterende landes.

Bemærkninger:

Der er ganske betydelige forskelle i indikatorresultaterne - men der er også klare forskelle i opgørelsesmetoder, der illustrerer behovet for at sikre entydige definitioner af indikatorerne forud for en endelig fortolkning af data.

Tabel 2.2.9.1.4 Graviditet og fødsel - levendefødte børn pr 1000 kvinder fordelt på aldersgrupper

\begin{tabular}{lccccccc}
\hline & 15-19 år & 20-24 år & 25-29 år & 30-34 år & 35-39 år & 40-44 år & 45-49 år \\
\hline Danmark 2009) & $5,6^{1}$ & $43,0^{1}$ & $123,6^{1}$ & $130,6^{1}$ & $56,6^{1}$ & $9,6^{1}$ & $0,5^{1}$ \\
Finland (2007) & $9,1^{2}$ & $58,8^{2}$ & $114,9^{2}$ & $117,1^{2}$ & $53,8^{2}$ & $11,4^{2}$ & $0,5^{2}$ \\
Færøerne & $14,3^{2}$ & $92,8^{2}$ & $174,4^{2}$ & $145,6^{2}$ & $69,7^{2}$ & $12,4^{2}$ & $0,5^{2}$ \\
$\begin{array}{l}\text { (2003-07) } \\
\text { Grønland }\end{array}$ & $43,3^{2}$ & $135,6^{2}$ & $124,6^{2}$ & $87,9^{2}$ & $44,5^{2}$ & $9,3^{2}$ & N/A \\
$\begin{array}{l}\text { (2003-07) } \\
\text { Island (2007) }\end{array}$ & $14,2^{2}$ & $77,4^{2}$ & $134,0^{2}$ & $121,9^{2}$ & $60,0^{2}$ & $10,2^{2}$ & $1,0^{2}$ \\
Norge (2007) & $9,1^{2}$ & $60,5^{2}$ & $122,3^{2}$ & $123,2^{2}$ & $54,1^{2}$ & $9,7^{2}$ & $0,4^{2}$ \\
Sverige (2009) & $5,8^{3}$ & $50,1^{3}$ & $114,8^{3}$ & $134,8^{3}$ & $67,5^{3}$ & $13,0^{3}$ & $0,7^{3}$ \\
\hline
\end{tabular}

Kilde: ${ }^{1}$ Det medicinske fødselsregister 2009+Danmarks Statistiks middelfolketal 2009. ${ }^{2}$ Health Statistics in the Nordic Countries 2007. ${ }^{3}$ Svensk abortstatistik, Sverige

Bemærkninger:

De 4 største nordiske lande har alle nogenlunde sammenlignelige fødselstal på tværs af aldersgrupper. Umiddelbart kan det anbefales at opgøre disse data over tid, så der bliver mulighed for at følge trends. 
Tabel 2.2.9.1.5. Graviditet og fødsel - rygning

\begin{tabular}{|c|c|c|}
\hline & $\begin{array}{l}\text { Procentdelen af gravide, der } \\
\text { ryger i begyndelsen af gravidi- } \\
\text { teten (ca. } 12 \text { uge) }\end{array}$ & $\begin{array}{l}\text { Procentdelen af gravide, der ryger under og } \\
\text { senere i graviditeten, mod uge } 30-32\end{array}$ \\
\hline Danmark (2009) & $N / A^{*}$ & $N / A^{*}$ \\
\hline $\begin{array}{l}\text { Finland }{ }^{\nabla}(2007) ; \\
(2008) ;{ }^{\circ}(2005)\end{array}$ & $14,7^{\varpi^{3}}$ & $10,3^{-3}$ \\
\hline Færøerne (2008) & $17.0^{-6}$ & N/A \\
\hline $\begin{array}{l}\text { Grønland (2006/Dep. } \\
\text { for sundhed) }\end{array}$ & 5,2 & $\mathrm{~N} / \mathrm{A}$ \\
\hline Island (2007) & N/A & N/A \\
\hline Norge (2008); ${ }^{\nabla}(2007)$ & $18,7^{\square 7}$ & $8,6^{7}$ \\
\hline $\begin{array}{l}\text { Sverige * (2008) } \\
{ }_{(2007)}\end{array}$ & $6,9 * 8$ & $5,1^{* 8}$ \\
\hline
\end{tabular}

Kilde: ${ }^{1}$ Medicinske fødselsregister, Sverige. ${ }^{3}$ THL Födelseregister 2008. ${ }^{6}$ Sundhedsberetning for Færøerne 2008. ${ }^{7}$ Medicinsk fødselsregister, Norsk. ${ }^{8}$ Det medicinske fødselsregister, Sverige. * Der er ikke tal for, hvornår i graviditeten kvinden har røget, kun om hun har eller ikke har røget og her er tallet $11,5 \%$ af gravide.

Bemærkninger:

På tværs af de 4 lande der har kunnet opgøre resultaterne, er der markante forskelle i procentdelen af gravide, der ryger. Sveriges tal afviger fra de 3 andres især i forhold til rygning i starten af graviditeten. 
Tabel 2.2.9.1.6. Graviditet og fødsel - barns tilstand

\begin{tabular}{|c|c|c|c|c|c|}
\hline & $\begin{array}{l}\text { Perinatal } \\
\text { mortalitet } \\
\text { pr. } 1000 \\
\text { fødsel }\end{array}$ & $\begin{array}{l}\text { Procentdel af } \\
\text { levendefødte } \\
\text { født efter } 37 \\
\text { uger med } \\
\text { fødselsvægt } \\
\text { under } 2500 \mathrm{~g}\end{array}$ & $\begin{array}{l}\text { Procentdel af } \\
\text { levendefødte } \\
\text { født efter } 37 \\
\text { uger med } \\
\text { fødselsvægt } \\
\text { på mindst } \\
4500 \mathrm{~g}\end{array}$ & $\begin{array}{l}\text { Procentdel af } \\
\text { børn, Ap- } \\
\text { garscore } \\
\text { under } 7\end{array}$ & $\begin{array}{l}\text { Procentdel a } \\
\text { børn, der } \\
\text { ammes til } \\
\text { seks måne- } \\
\text { der }\end{array}$ \\
\hline Danmark (2009) & 6,2 & $1,6^{1}$ & $3,0^{1}$ & $0,7^{1}$ & N/A \\
\hline $\begin{array}{l}\text { Finland }{ }^{\circ}(2005) \\
{ }^{\nabla}(2007)^{*}(2008)\end{array}$ & $5,1^{\nabla 6}$ & $1,2^{\bullet 2}$ & $2,7^{\bullet 2}$ & $5,9^{\bullet 2}$ & $60^{\diamond 5}$ \\
\hline $\begin{array}{l}\text { Færøerne }{ }^{\nabla}(2007) \\
\text { (2008) }\end{array}$ & $5,9^{\nabla 6}$ & $3,0^{* 3}$ & $7^{\bullet 3}$ & $6,0^{\star 3}$ & N/A \\
\hline $\begin{array}{l}\text { Grønland (2008/ } \\
\text { Dep. for sundhed) }\end{array}$ & 20,3 & 4,5 & 3,4 & 0,7 & N/A \\
\hline Island (2007) & $2,6^{2}$ & $\mathrm{~N} / \mathrm{A}$ & N/A & N/A & N/A \\
\hline Norge (2007) & $5,8^{6}$ & N/A & N/A & N/A & N/A \\
\hline $\begin{array}{l}\text { Sverige }{ }^{\otimes}(2007) \\
{ }^{\bullet}(2008)\end{array}$ & $4,8^{\bullet 8}$ & $1,2^{\bullet}$ & $3,5^{\bullet}$ & $0,01^{* 4}$ & $12,3^{\otimes 8}$ \\
\hline
\end{tabular}

Kilde: ${ }^{1}$ Det medicinske fødseksregister 2009. ${ }^{2}$ THL Födelseregister 2008. ${ }^{3}$ Sundhedsberetning for Færøerne2008. ${ }^{4}$ Det Medicinsk fødselsregister, Sverige. ${ }^{5}$ Social- och hälsoministeriet 2005

Bemærkninger:

Den perinatale motalitet ligger i de 4 store nordiske lande samt Færøerne nogenlunde på samme niveau. De forskelle, der ses i forhold til Grønland og Island kan skyldes tilfældig variation på grund af deres lille befolkningstal. Der bør være fokus på om tendenserne holder på tværs af tid mhp. at give mulighed for at vurdere om forskellene er signifikante.

Resultaterne for procentdel af børn med fødselsvægt uden for det normale er nogenlunde ens på tværs af de 4 lande, der har kunnet levere data.

Det må antages, at opgørelsesmetode eller registreringspraksis i de nordiske lande afviger i forhold til apgarscore, da forskellen mellem hhv. Danmark/Sverige hhv. Finland/Færøerne er store taget landenes forholdsvis ens sundhedssystemer og adgang til fødselshjælp i betragtning. 
Tabel 2.2.9.1.7 Graviditet og fødsel - strukturindikatorer

\begin{tabular}{lll}
\hline & $\begin{array}{l}\text { Eksisterer der et nationalt klinisk } \\
\text { kvalitetsregister for fødselsområdet? }\end{array}$ & $\begin{array}{l}\text { Eksisterer der kliniske retningslinjer } \\
\text { på fødselsområdet? }\end{array}$ \\
\hline Danmark (2009) & $\mathrm{Ja}$ & $\mathrm{Ja}$ \\
Finland & $\mathrm{N} / \mathrm{A}$ & $\mathrm{N} / \mathrm{A}$ \\
Færøerne & $\mathrm{Ja}^{1}$ & $\mathrm{Ja}^{1}$ \\
Grønland & $\mathrm{N} / \mathrm{A}$ & $\mathrm{N} / \mathrm{A}$ \\
Island & $\mathrm{N} / \mathrm{A}$ & $\mathrm{N} / \mathrm{A}$ \\
Norge & $\mathrm{N} / \mathrm{A}$ & $\mathrm{N} / \mathrm{A}$ \\
Sverige (2008) & $\mathrm{Ja}$ & $\mathrm{Nej}$ \\
\hline
\end{tabular}

${ }^{1}$ Status pr. medio 2010.

Bemærkninger

Kun 3 lande har kunnet levere oplysningerne.

Tabel 2.2.9.2 Potentielle indikatorer vedrørende graviditet og fødsel

\begin{tabular}{ll}
\hline Indikatornavn & Definitioner \\
\hline Graviditet og & Kvalitetsindikatorer \\
fødsel & Der bør udvikles fælles nordiske indikatorer der belyser, om kvinden får den rette \\
& graviditets- og fødselshæelp i overensstemmelse med nationale kliniske retningslinjer \\
& Eksempler på indikatorer: \\
& Perinatalomsorg jf. gældende nationale kliniske retningslinjer \\
& Andel af gravide og fødende kvinder, som får omsorg jf. gældende nationale \\
& kliniske retningslinjer. \\
\hline
\end{tabular}

\subsubsection{Børn og unge}

Nedenfor er opgjort resultater for børn og unge i forhold til de følgende områder:

- Risikoadfærd - (mis)brug af alkohol, tobak og hash

- Fysisk aktivitet og helbredstilstand

- Seksuel aktivitet

- Selvmord

- Vaccination.

Der er også indsamlet oplysninger vedr. strukturindikatorer, der afdækker eksistens af kliniske retningslinjer/kliniske registre. De indsamlede oplysninger tillader ikke umiddelbar skematisk fremstilling, og er derfor præsenteret i komplet form i bilag 3 - oversigt over registre/retningslinjer for børn/unge. 


\subsubsection{Risikoadfcerd - begrundelse for valg af område}

Risikoadfærd blandt børn og unge har betydning for sundhedstilstanden i befolkningen og er derfor vigtig at monitorere

Tabel 2.2.10.1.1. Børn og unge - risikoadfærd; (mis)brug af alkohol, tobak og hash

\begin{tabular}{|c|c|c|c|}
\hline & $\begin{array}{l}\text { Procentdel af unge, der har } \\
\text { været fulde flere gange, } \\
15 \text { årige } \\
\text { (Piger/drenge) }\end{array}$ & $\begin{array}{l}\text { Unge, der ryger } \\
\text { dagligt, } \\
15 \text { årige i procent } \\
\text { (Piger/drenge) }\end{array}$ & $\begin{array}{l}\text { Unge, der ryger hash, } \\
15 \text { årige i procent }\end{array}$ \\
\hline Danmark (2007) & $71 / 75^{\square} 1_{*}$ & $14^{3}$ & $10,6^{\bullet^{1 \wedge}}$ \\
\hline Finland (2005-2006) & $44 / 47^{\nabla 2 *}$ & $21 / 23^{\nabla 2 \infty}$ & $1 / 3^{2 \otimes}$ \\
\hline Færøerne (2007) & $28^{4 \diamond}$ & $21^{4}$ & $6^{4}$ \\
\hline Grønland (2005-2006) & $13 / 11^{2 *}$ & $48 / 37^{2 \infty}$ & $3 / 5^{2 \otimes}$ \\
\hline Island (2005-2006) & $19 / 19^{2 *}$ & $13 / 14^{2 \infty}$ & $3 / 4^{2 \otimes}$ \\
\hline Norge (2005-2006) & $10 / 11^{2 *}$ & $12 / 9^{\nabla 2 \infty}$ & $\mathrm{N} / \mathrm{A}$ \\
\hline Sverige (2005-2006) & $9 / 15^{2}$ & $9 / 8^{2 \infty}$ & $1 / 2^{2 \otimes}$ \\
\hline
\end{tabular}

Kilde: ${ }^{1}$ The 2007 ESPAD Report. ${ }^{2}$ Health behaviour in school-aged children international report from the 2005/2006 survey. ${ }^{4}$ ESPAD $2007 .{ }^{3}$ Sundhedsstyrelsen, Danmark * drenge og piger i alderen 15-16 år der har været fulde indenfor det sidste år. * 15-årige, der har været fulde mindst to gange $\diamond$ samlet for piger og drenge, fulde tre gange eller mere 15 år gamle drikker alkohol mindst en gang om ugen $\wedge$ 15-16 årige der har prøvet hash indenfor seneste år. $\infty 15$-årige, der røg mindst en gang om ugen ${ }^{\otimes} 15$-årige, der har røget hash inden for de sidste 30 dage

Bemærkninger:

Der er stor forskel på opgørelsesmetoder i forhold til alkohol/tobak og hash (alder, måned/uge, antal), hvilket gør det vanskeligt at sikre sammenlignelige data, til trods for at der er offentliggjort flere rapporter om unge menneskers sundhed.

Der er umiddelbart forskelle mellem de nordiske lande ift. risikoadfærd, men pga. de forskellige opgørelsesmetoder, er det ikke muligt at lave en endelig konklusion i forhold til disse forskelle. Det anbefales, at der sikres ensartede definitioner af indikatorerne. 
Tabel 2.2.10.1.2 Børn og unge - fysisk aktivitet, helbredstilstand, seksuel aktivitet og selvmord

\begin{tabular}{|c|c|c|c|c|c|}
\hline & $\begin{array}{l}\text { Procentdel af } \\
\text { børn, der er } \\
\text { fysisk aktive } \\
13 \text { årige } \\
\text { (Piger/drenge) }\end{array}$ & $\begin{array}{l}\text { Procentdel af } \\
\text { 13-årige, der } \\
\text { vurderer } \\
\text { deres helbred } \\
\text { som rimelig } \\
\text { eller dårlig } \diamond \\
\text { (Piger/drenge) }\end{array}$ & $\begin{array}{l}\text { Børn og unge, } \\
\text { der udsættes } \\
\text { for alvorlig } \\
\text { ulykke } \\
\text { pr. } 100.000\end{array}$ & $\begin{array}{l}\text { Procentdel af } \\
15 \text { årige, der } \\
\text { er seksuelt } \\
\text { aktive unge } \\
\text { (Piger/drenge) }\end{array}$ & $\begin{array}{l}\text { Selvmord } \\
\text { blandt børn } \\
\text { og unge } \\
\text { pr. } 100000 \\
\text { indbyggere } \\
\text { (Piger/drenge) }\end{array}$ \\
\hline $\begin{array}{l}\text { Danmark } \\
(2005-2006) \text {; } \\
\text { *(2006) }\end{array}$ & $17 / 29^{1 *}$ & $17 / 12^{1}$ & N/A & $31^{3}$ & $1,5 / 2,0^{* 7}$ \\
\hline $\begin{array}{l}\text { Finland } \\
\text { (2005-2006) } \\
\nabla(2008) \\
*(2007)\end{array}$ & $15 / 24^{4 \oplus}$ & $13 / 9^{1}$ & $489,81^{\nabla 5}$ & $30 / 25^{-4}$ & $2,8 / 10,0^{* 7}$ \\
\hline $\begin{array}{l}\text { Færøerne } \\
\text { (2009) }\end{array}$ & N/A & N/A & N/A & N/A & $0 / 0^{7}$ \\
\hline $\begin{array}{l}\text { Grønland } \\
(2005-2006) \\
\text { *(2005) }\end{array}$ & $23 / 28^{4 \oplus}$ & $24 / 16^{1}$ & $2,6^{8}$ & $61,0^{9}$ & $\begin{array}{l}62,4 / \\
61,3^{* 7}\end{array}$ \\
\hline $\begin{array}{l}\text { Island } \\
(2005-2006) \\
*(2003-2007)\end{array}$ & $14 / 24^{4 \oplus}$ & $18 / 16^{1}$ & N/A & $36 / 29^{-4}$ & $N A / 8,5 \%$ \\
\hline $\begin{array}{l}\text { Norge } \\
(2005-2006) \\
{ }^{*}(2006)\end{array}$ & $14 / 15^{4 \oplus}$ & $19 / 14^{1}$ & N/A & N/A & $2,0 / 7,6^{* 7}$ \\
\hline $\begin{array}{l}\text { Sverige } \\
(2005-2006) \\
\nabla(2008) \\
*(2007)\end{array}$ & $14 / 21^{-4 \oplus}$ & $14 / 7^{1}$ & $635,7^{\nabla 6}$ & $32 / 25^{\square 4}$ & $3,0 / 5,9^{* 7}$ \\
\hline
\end{tabular}

Kilde: ${ }^{1}$ Sundhedsstyrelsen (Danmark). Undersøgelse af 11-15-åriges livsstil og sundhedsvaner $2008 .{ }^{3}$ Sundhedstyrelsen, Danmark. ${ }^{4}$ Health behaviour in school-aged children international report from the 2005/2006 survey.

${ }^{5}$ Utskrivningsregister $2008 .{ }^{6} \mathrm{Health}$ indicators for Swedish children. A contribution to a municipal index. Stockholm, Save the Children, Sweden. ${ }^{7}$ Health Statistics in the Nordic Countries 2007; $\diamond$ oprindeligt blev der spurgt til „Børn med godt selvvurderet helbred, 13 årige“. Data der er tilgængelig understøtter ikke denne spørgemåde, og der er ikke mulighed for at konvertere svarene om til det oprindelige spørgsmål; * fysisk aktiv i mindst en time om dagen (inkl. i skolen) i løbet af den seneste uge. $\oplus$ Mindst en time af moderat til energisk aktivitet dagligt $\bullet$ samlet for alderen 10-19 år. ${ }^{8}$ Gennemsnit for 2004-6, kilde: Departement for Sundhed, Grønland; ${ }^{9}$ HBSC 2006.

\section{Bemærkninger}

Jf. bemærkninger til tabel 2.2.10.1.1. omkring problemer med forskellige opgørelsesmetoder samt kendte kulturforskelle i forhold til survey, er det ikke muligt at konkludere endeligt om de forskelle, der er i landenes resultater, er udtryk for faktiske adfærdsforskelle. Det kan dog bemærkes, at der i enkelte lande er markante kønsforskelle i forhold til fysisk aktivitet og selvopfattet helbred. Ligesom den markant højere selvmordsrate i Grønland også tillader en konklusion om, at selvmord er mere udbredt blandt grønlandske børn og unge. De andre selvmordsrater er umiddelbart så lave, at der ikke meningsfuldt kan konkluderes på de tilsyneladende forskelle. 


\subsubsection{Vaccination - begrundelse for valg af område}

Der er høj dækning i Norden vedrørende småbørnsvaccinationerne, men MMR er dårligst dækket, derfor har den interesse frem for de øvrige vaccinationer, og det er vigtigt, at børnene får den første vaccination som små, fordi MMR sygdommene her kan have et alvorligt forløb. Der er ligeledes høj dækning i Norden vedr. småbørnsvaccinationerne. Derimod er det vanskeligere at opnå høj dækningsgrad af de 12-årige, og dette område bør derfor monitoreres.

Udover de oplyste indikatorer var der planlagt indsamlet oplysninger om vaccination mod HPV - ingen af de nordiske lande har dog kunne fremskaffe oplysningerne, og indikatoren er udeladt.

Tabel 2.2.10.2.1. Børn og unge - vaccination

\begin{tabular}{|c|c|c|c|c|c|c|}
\hline & $\begin{array}{l}\text { Procentdel af } \\
\text { børn og unge } \\
\text { vaccineret } \\
\text { mod mæslin- } \\
\text { ger }\end{array}$ & $\begin{array}{l}\text { Procent- } \\
\text { del af } 2 \\
\text { årige } \\
\text { vaccine- } \\
\text { ret for } \\
\text { MFR }\end{array}$ & $\begin{array}{l}\text { Procent- } \\
\text { del af } 12 \\
\text { årige } \\
\text { vaccine- } \\
\text { ret for } \\
\text { MFR }\end{array}$ & 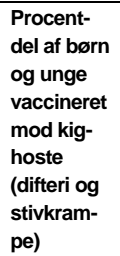 & $\begin{array}{l}\text { Procent- } \\
\text { del af børn } \\
\text { på } 1 \text { eller } \\
2 \text { år, som } \\
\text { er fuldt } \\
\text { vaccineret } \\
\text { mod } \\
\text { mæsling- } \\
\text { er. }\end{array}$ & $\begin{array}{l}\text { Procent- } \\
\text { del af børn } \\
\text { på } 1 \text { eller } \\
2 \text { år, som } \\
\text { er fuldt } \\
\text { vaccineret } \\
\text { mod } \\
\text { hepatitis } \\
\text { B. }\end{array}$ \\
\hline Danmark (2008) & $85^{1}$ & $88^{1}$ & $86^{1}$ & $89^{1}$ & $88^{1}$ & N/A \\
\hline Finland (2010) & $98,5^{2}$ & $98,5^{2}$ & N/A & $99,3^{2}$ & $98,5^{2}$ & N/A \\
\hline Færøerne & N/A & N/A & N/A & N/A & N/A & N/A \\
\hline $\begin{array}{l}\text { Grønland (2008/ } \\
\text { Dep. for sundhed) }\end{array}$ & $\begin{array}{l}\text { Del af MRF, } \\
\text { se rate herfor }\end{array}$ & 88,6 & 78,9 & 100 & N/A & N/A \\
\hline Island (2007) & $95^{3}$ & N/A & N/A & $97^{3}$ & N/A & N/A \\
\hline $\begin{array}{l}\text { Norge (2007) } \\
*(2008)\end{array}$ & 933 & $92 * 4$ & $94 * 4$ & $92 * 4$ & $93 * 4$ & N/A \\
\hline Sverige & $96,7^{5 \nabla}$ & $96,7^{5}$ & $94,9^{5}$ & $98,4^{5}$ & $96,7^{5}$ & $22,5^{5}$ \\
\hline
\end{tabular}

Kilde: ${ }^{1}$ Statens Serums Institut. ${ }^{2} \mathrm{THL}$ Undersökning om vaccinationer, 2010. ${ }^{3} \mathrm{Health}$ Statistics in the Nordic Countries 2007. ${ }^{4}$ SYSVAK. ${ }^{5}$ Smittskyddsinstitutet - vaccinationsstatistik BVC $\nabla$ I Sverige anvendes hovedsagelig MFR (Mæslinger +Fåresyge + Rubella).

Bemærkninger

Der er generelt høj dækning i Norden for vaccinationer, der er dog nogle forskelle mellem landene f.eks. ligger Danmark under niveau for de nordiske landes niveau, der har opgjort resultaterne. Det anbefales, at datakilder og opgørelsesmetode undersøges mhp. at konstatere, om denne forskel er udtryk for reelle forskelle i vaccinationsniveau og herunder forskelle i, hvorledes landenes vaccinationsprogrammer fungerer. 
Tabel 2.2.10.3 Potentielle indikatorer vedrørende børn og unge

Definitioner
Kvalitetsindikator
Der bør udvikles fælles nordiske indikatorer der belyser, om børn og unge får den rette diagnostik
og behandling i overensstemmelse med nationale kliniske retningslinjer
Der bør udvikles fælles løbende monitorering af vaccinationsprogrammer

\subsubsection{Forebyggelse og sundhedsfremme}

\subsubsection{Begrundelse for valg af område}

Indikatorerne vedr. forebyggelse er udvalgt med fokus på kønssygdomme, og kendte risikofaktorer (alkohol- og tobaksforbrug, fedme) mhp. at afdække sundhedstilstanden i de nordiske lande.

Øvrige områder dækker livsstilsfaktorer med kendt stor betydning for morbiditet og mortalitet i de nordiske befolkninger.

I øvrigt gør de følgende begrundelser sig gældende for de konkrete områder.

Tobaksanvendelse er den største forebyggelige dødsårsag ifølge WHO’s European Health Report 2005. Når man tager højde for alle indtægts- og udgiftskilder i en økonomisk beregning udgør tobaksanvendelse et nettotab for samfundsøkonomien. Og samtidig er forebyggelsesindsatserne imod tobaksanvendelse særdeles effektive i et cost-efficiency perspektiv (7). Derfor er indikatorer på tobaksanvendelse relevante både udfra et klinisk perspektiv og et policy perspektiv.

Overvægt har en stærk negativ indflydelse på livskvalitet og forbindes med øget mortalitet. Overvægt øger risikoen for hypertension, dyslipidæmi, diabetes type II, hjertesygdom, hjerneinfarkt, galdeblæresygdom, knogleledsbetændelse, søvnapnø, respirationsproblemer, cancer i livmoderslimhinde, bryst-, prostata- og coloncancer (8). Antallet af overvægtige individer er stærkt stigende og medfører dyre behandlinger samt overdødelighed. Dette, samt de gode muligheder for at forebygge betyder, at overvægt rangerer højt på listen over internationale fokusområder indenfor forebyggelse og sundhedsfremme.

Den store sygdomsbyrde, som skyldes skadeligt forbrug af alkohol samt tilstedeværelsen af effektive metoder til at reducere denne byrde, betyder, at alkoholproblemer er et vigtigt og relevant område for sundhedsfremme- og forebyggelsesarbejde. 
Incidensen af seksuelt overførte sygdomme vedbliver at være af stor relevans både set fra en klinisk synsvinkel og fra en policy-relateret synsvinkel. Ubehandlede klamydiainfektioner kan føre til nedsat fertilitet. Infektionen er dog let at behandle. Ændringer i incidensen af klamydiainfektioner formidler desuden vigtig information om udbredelsen af seksuel risikoadfærd, herunder ubeskyttet samleje. Derfor kan incidens af klamydiainfektioner og andre kønssygdomme fungere som proxy for et estimat for risikoen for HIV-smitte (9).

Nedenfor er opgjort resultater for de flg. områder:

- Klamydiainfektioner

- Rygning, alkohol, fedt, kalorier, sukker, frugt og grønt

- Overvægt

- Strukturindikatorer.

Tabel 2.2.11.1.1 Forebyggelse og sundhedsfremme - klamydiainfektioner

\begin{tabular}{llll}
\hline & $\begin{array}{l}\text { Klamydiainfektioner pr } \\
\mathbf{1 0 0 . 0 0 0} \text { indbyggere }\end{array}$ & $\begin{array}{l}\text { Klamydiainfektioner pr } \\
\mathbf{1 0 0 . 0 0 0} \text { indbyggere } \\
\text { (Kvinder) }\end{array}$ & $\begin{array}{l}\text { Klamydiainfektioner pr } \\
\mathbf{1 0 0 . 0 0 0} \text { indbyggere } \\
\text { (Mænd) }\end{array}$ \\
\hline Danmark (2007) & $472^{1}$ & $584^{1}$ & $358^{1}$ \\
Finland (2007) & $264^{1}$ & $306^{1}$ & $221^{1}$ \\
Færøerne (2007) & $223^{1}$ & $301^{1}$ & $155^{1}$ \\
Grønland (2007) & $4.172^{1}$ & $4.981^{1}$ & $3.489^{1}$ \\
Island (2007) & $578^{1}$ & $726^{1}$ & $436^{1}$ \\
Norge (2007) & $482^{1}$ & $598^{1}$ & $367^{1}$ \\
Sverige (2007) & $457^{2}$ & $502^{2}$ & $398^{2}$ \\
\hline
\end{tabular}

Kilde: ${ }^{1}$ Health Statistics in the Nordic Countries 2007. ${ }^{2}$ Smittskyddsinstitutet, Epidemiologisk årsrapport 2008

Bemærkninger:

Udbredelsen af klamydiainfektioner svinger særdeles meget blandt de nordiske lande, hvor især Grønlands resultat afviger markant. 
Tabel 2.2.11.1.2. Forebyggelse og sundhedsfremme - rygning, alkohol, fedt, kalorier, sukker, frugt og grønt

\begin{tabular}{|c|c|c|c|c|c|c|c|}
\hline & $\begin{array}{l}\text { Procent- } \\
\text { del af } \\
\text { befolk- } \\
\text { ningen, } \\
\text { der ryger }\end{array}$ & $\begin{array}{l}\text { Gennem- } \\
\text { snitligt } \\
\text { antal } \\
\text { cigaretter } \\
\text { pr. ryger } \\
\text { pr. dag (15 } \\
\text { år +) }\end{array}$ & $\begin{array}{l}\text { Årligt forbrug } \\
\text { af ren alkohol } \\
\text { i liter pr. } \\
\text { person i } \\
\text { alderen (15 år } \\
+ \text { ) }\end{array}$ & $\begin{array}{l}\text { Total } \\
\text { fedtind- } \\
\text { tag: } \\
\text { (gram pr. } \\
\text { indbyg- } \\
\text { ger pr. } \\
\text { dag) }\end{array}$ & $\begin{array}{l}\text { Total } \\
\text { kalorier } \\
\text { og } \\
\text { protein } \\
\text { indtag: } \\
\text { (pr. ind- } \\
\text { bygger } \\
\text { pr. dag) }\end{array}$ & $\begin{array}{l}\text { Sukker } \\
\text { forbrug } \\
\text { (kg. pr } \\
\text { ind- } \\
\text { bygger } \\
\text { pr år.) }\end{array}$ & $\begin{array}{l}\text { Frugt og } \\
\text { grøntsager } \\
\text { kg. pr } \\
\text { indbygger } \\
\text { pr år.) }\end{array}$ \\
\hline $\begin{array}{l}\text { Danmark } \\
{ }^{\star}(2002-2005) \\
{ }^{\nabla}(2008)\end{array}$ & 21 & 9,67 & $\begin{array}{l}11,7^{\nabla 2} \\
\text { (NOMESCO } \\
2007: 10,9 \text { ) }\end{array}$ & $\mathrm{N} / \mathrm{A}$ & $\mathrm{N} / \mathrm{A}$ & $\mathrm{N} / \mathrm{A}$ & N/A \\
\hline $\begin{array}{l}\text { Finland } \\
*(2002-2005) \\
\nabla(2007) \\
(2008)\end{array}$ & $23^{* 1}$ & 14,7 & $10,5^{\vee 3}$ & $107,7^{-4}$ & $2795^{-4}$ & $31,8^{4}$ & $149,9^{\square 4}$ \\
\hline $\begin{array}{l}\text { Færøerne } \\
{ }^{\nabla}(2007)\end{array}$ & N/A & N/A & $7,2^{\nabla 3}$ & $\mathrm{~N} / \mathrm{A}$ & N/A & N/A & N/A \\
\hline $\begin{array}{l}\text { Grønland } \\
{ }^{*}(2006) \\
\nabla(2007) \\
(2008) \\
*(2009)\end{array}$ & $65^{\square}$ & $6^{*}$ & $\begin{array}{l}10,6^{7} \\
12,0^{\nabla 3}\end{array}$ & N/A & $\mathrm{N} / \mathrm{A}$ & $29 *$ & $105^{\circ}$ \\
\hline $\begin{array}{l}\text { Island } \\
{ }^{\star}(2002-2005) \\
{ }^{\nabla}(2007)\end{array}$ & $19,8^{* 1}$ & $\mathrm{~N} / \mathrm{A}$ & $7,5^{\vee 3}$ & N/A & $\mathrm{N} / \mathrm{A}$ & $\mathrm{N} / \mathrm{A}$ & N/A \\
\hline $\begin{array}{l}\text { Norge } \\
*(2002-2005) \\
\nabla(2007) \\
(2003)\end{array}$ & $26^{* 1}$ & $\mathrm{~N} / \mathrm{A}$ & $6,6^{\nabla 3}$ & $145,1^{-5}$ & N/A & N/A & $190,7^{5}$ \\
\hline $\begin{array}{l}\text { Sverige } \\
*(2002-2005) \\
\nabla(2008) \\
(2003) \\
{ }^{*}(2009)\end{array}$ & $16^{* 1}$ & N/A & $6,9^{\nabla 3}$ & $126,6^{-5}$ & $3208^{5}$ & $39 * 6$ & $184^{* 6}$ \\
\hline
\end{tabular}

Kilder: ${ }^{1} \mathrm{WHO}$, Tobacco control database. ${ }^{2}$ Sundhedsstyrelsen, Danmark. ${ }^{3}$ Health Statistics in the Nordic Countries 2007. ${ }^{4}$ Statens Folkhälsoinstitut, försäljningsstatistik år $2008^{4}$ : Jord- och skogsbruksministeriets informationstjänstcentral 2008. ${ }^{5}$ OECD Health Data. ${ }^{6}$ Jordbruksverket Statistikrapport. ${ }^{7}$ Departement for sundhed, Grønland. Dette forbrug består både af det registrerede salg suppleret med skøn over det uregistrerede forbrug.

Bemærkninger:

Resultaterne viser ganske markante forskelle i forbrug på tværs af de nordiske lande. De 2 indsatte resultater for alkoholforbrug i Danmark viser betydning af definition af indikatoren, hvor det første tal inkluderer et skøn over det uregistrerede forbrug (privat import fra andre lande, typisk Tyskland). Jf. forskellen på $10 \%$ i de 2 tal skal de mindre forskelle i disse resultater på tværs af landene fortolkes med forsigtighed, hvor det dog er markant, at Grønland, Danmark og Finland har et større alkoholforbrug end de resterende landes.

Flere af disse data er indhentet via survey og svar på disse kan være kulturafhængig jf. afsnit 2.2.13.1, derfor skal forskelle fortolkes med forsigtighed. 
Tabel 2.2.11.1.3. Forebyggelse og sundhedsfremme - overvægt

\begin{tabular}{|c|c|c|c|}
\hline & $\begin{array}{l}\text { Overvægt i befolkningen } \\
\text { Procentdel af patienter } \\
\text { med BMI større end lig } \\
25 \text { og mindre end } 30(\mathrm{Cl})\end{array}$ & $\begin{array}{l}\text { Fedme i befolkningen } \\
\text { Procentdel af patienter } \\
\text { med BMI større end lig } \\
30(\mathrm{Cl})\end{array}$ & $\begin{array}{l}\text { Overvægtige eller fedme } \\
\text { i befolkningen } \\
\text { Procentdel af patienter, } \\
\text { der har BMI over } 25(\mathrm{Cl})\end{array}$ \\
\hline Danmark (2007) & N/A (N/A) & $11,4^{1}(\mathrm{~N} / \mathrm{A})$ & $\mathrm{N} / \mathrm{A}(\mathrm{N} / \mathrm{A})$ \\
\hline Finland (2007) & $34.0(\mathrm{~N} / \mathrm{A})$ & $14,9^{1}(\mathrm{~N} / \mathrm{A})$ & $48.9(\mathrm{~N} / \mathrm{A})$ \\
\hline Færøerne (2009) & $40^{2}(\mathrm{~N} / \mathrm{A})$ & $12,0^{2}(\mathrm{~N} / \mathrm{A})$ & $52^{2}(\mathrm{~N} / \mathrm{A})$ \\
\hline Grønland (2005-7) & $\mathrm{N} 29,9(\mathrm{~N} / \mathrm{A})^{\square 4}$ & $23,9(\mathrm{~N} / \mathrm{A})^{\square 4}$ & $53,8(N / A)^{\sqsubset 4}$ \\
\hline Island (2007) & $N / A(N / A)$ & $20,1^{1}(\mathrm{~N} / \mathrm{A})$ & N/A (N/A) \\
\hline Norge (2007) & $\mathrm{N} / \mathrm{A}(\mathrm{N} / \mathrm{A})$ & $9,0^{1}(\mathrm{~N} / \mathrm{A})$ & N/A (N/A) \\
\hline Sverige (2008) & $34,4^{3 \nabla}(\mathrm{N} / \mathrm{A})$ & $9,9^{3 \nabla}(\mathrm{N} / \mathrm{A})$ & $44,3^{3 \nabla}(\mathrm{N} / \mathrm{A})$ \\
\hline
\end{tabular}

Kilde: ${ }^{1} \mathrm{OECD}, 2009 .{ }^{2}$ Gallup Føroyar 2009 fyri Fólkaheilsuráðið. ${ }^{4} \mathrm{SCB}$, Undersökningen om levnadsförhållanden (ULF), överviktiga. ${ }^{4}$ Departement for sundhed, Grønland. ${ }^{\nabla}$ Opgørelsen er for 16 år og derover

Bemærkninger

Alene resultater for procentdelen af overvægtige har kunnet opgøres for flere lande - her viser resultater store forskelle, hvor procentdelen af patienter med fedme svinger mellem 9 og $20 \%$. I fortolkningen af forskellene skal tages højde for, at resultaterne stammer for forskellige år, ligesom der ikke er konfidensintervaller på tallene, og det dermed ikke kan vurderes, om forskellene er statistiske signifikante. 
Tabel 2.2.11.1.4. Forebyggelse og sundhedsfremme - strukturindikatorer

\begin{tabular}{|c|c|c|c|c|c|}
\hline & $\begin{array}{l}\text { Eksisterer der } \\
\text { nationale } \\
\text { kliniske } \\
\text { registre på } \\
\text { området? }\end{array}$ & $\begin{array}{l}\text { Eksisterer der } \\
\text { kliniske } \\
\text { retningslinjer } \\
\text { på området? }\end{array}$ & $\begin{array}{l}\text { Eksisteret der } \\
\text { survey } \\
\text { programmer } \\
\text { på området? }\end{array}$ & $\begin{array}{l}\text { Eksisterer der i } \\
\text { sygehusvæse- } \\
\text { net eller i kom- } \\
\text { munalt regi til- } \\
\text { bud om ryge- } \\
\text { stopkursus? }\end{array}$ & $\begin{array}{l}\text { Eksisterer der } \\
\text { i primærsek- } \\
\text { tor tilbud om } \\
\text { rygestopkur- } \\
\text { sus? }\end{array}$ \\
\hline $\begin{array}{l}\text { Danmark (status } \\
\text { juni, 2010) }\end{array}$ & $\mathrm{Ja}$ & $\mathrm{Ja}$ & $\mathrm{Ja}$ & $\mathrm{Ja}$ & $\mathrm{Ja}$ \\
\hline $\begin{array}{l}\text { Finland (status } \\
\text { juni, 2010) }\end{array}$ & $\mathrm{Ja}$ & $\mathrm{Ja}$ & $\mathrm{Ja}$ & $\mathrm{Ja}$ & $\mathrm{Ja}$ \\
\hline $\begin{array}{l}\text { Færøerne (status } \\
\text { juni, 2010) }\end{array}$ & $\mathrm{Ja}$ & Nej & $\mathrm{Ja}$ & Nej & $\mathrm{Nej}$ \\
\hline $\begin{array}{l}\text { Grønland (status } \\
\text { juni, 2010) }\end{array}$ & $\mathrm{Ja}$ & Nej & $\mathrm{Ja}$ & $\mathrm{Ja}$ & $\mathrm{Nej}$ \\
\hline $\begin{array}{l}\text { Island (status } \\
\text { juni, 2010) }\end{array}$ & $\mathrm{Ja}$ & $\mathrm{Ja}$ & N/A & N/A & N/A \\
\hline $\begin{array}{l}\text { Norge (status } \\
\text { juni, 2010) }\end{array}$ & $\mathrm{Ja}$ & $\mathrm{Ja}$ & $\mathrm{Ja}$ & Nej & Nej \\
\hline $\begin{array}{l}\text { Sverige (status } \\
\text { juni, 2010) }\end{array}$ & $\mathrm{Ja}$ & $\mathrm{Ja}^{*}$ & $\mathrm{Ja}$ & N/A & N/A \\
\hline
\end{tabular}

* Under etablering

Bemærkninger:

Alle lande har kliniske retningslinjer for forebyggelse og sundhedsfremme - ligesom alle de 5 store nordiske lande har kliniske retningslinjer og gennemfører surveyprogrammer.

Ift. rygestop har 4 lande leveret oplysninger om rygestopkursus; her har Danmark og Finland tilbud, mens Norge og Færøerne ikke har det. Det kan anbefales at gennemføre en undersøgelse af sammenhæng mellem tilbud og rygestop og andel af befolkningen, der ryger, men det ville kræve oplysninger for de 2 indikatorer opgjort over tid.

Tabel 2.2.11.2 Potentielle indikatorer vedrørende forebyggelse og sundhedsfremme

\begin{tabular}{ll}
\hline Indikatornavn & Definitioner \\
\hline $\begin{array}{l}\text { Forebyggelse og } \\
\text { sundhedsfremme }\end{array}$ & Kvalitetsindikator \\
& $\begin{array}{l}\text { Der bør udvikles relevante indikatorer for alle aldersgrupper, der monitorerer } \\
\text { kvaliteten af respektive landes folkesundhedsprogrammer }\end{array}$ \\
\hline
\end{tabular}

\subsubsection{Psykiatri}

Nedenfor er opgjort resultater for de flg. områder:

- Retningslinjer/registre

- Tvangsindlæggelser

- Ikke planlagt genindlæggelser

- Ventetider

- Selvmord. 
Herudover er der vedtaget følgende indikatorer:

- Overdødelighed for de store psykiatriske sygdomme

- Forebygggelige indlæggelser for patienter med angst- eller depressionsdiagnoser

- Ventetid til første konsultation

- Andel af patienter der indlægges som følge af forsøg på selvmord.

Ingen af de nordiske lande har indleveret data for disse, og de fremgår derfor ikke af tabellerne.

\subsubsection{Begrundelse for valg af område}

Indikatorerne vedr. psykiatri er udvalgt med fokus på tvang, genindlæggelse, ventetider og selvmord. Områderne er udvalgt med følgende begrundelser:

\section{Tvang}

Tvangsindlæggelser er et alvorligt indgreb i den personlige frihed. Det er derfor etisk, faglig og samfundsmæssigt vigtigt at overvåge brugen af tvang for at begrænse denne til de helt nødvendige situationer. Vigtigheden understreges af, at undersøgelser har vist, at der er internationale og intraregionale forskelle i brugen af tvang, som ikke kan forklares af forskelle i patientsammensætningen.

\section{Genindlaggelse}

Uplanlagte genindlæggelser er forbundet med omkostninger for såvel patient som behandlingssystem, og det er vigtigt at overvåge, at patientforløb tilrettelægges og afsluttes på en måde, som sikrer imod behov for efterfølgende uplanlagte genindlæggelser.

\section{Ventetider}

Det er et mål, at der er god tilgængelighed for borgere med psykiatriske lidelser. I alle de nordiske lande har det vært fokuseret på kapacitet og tilgængelighed i det psykiatriske behandlingssystem. Kort ventetid kan bidrage til at øge tilliden til det psykiatriske behandlingssystem, ligesom det har stor betydning for patienternes livskvalitet at komme i hurtig behandling. 


\section{Selvmord}

At reducere antallet af selvmord i befolkningen er en vigtig målsætning $\mathrm{i}$ alle nordiske lande. Det psykiatriske behandlingssystem har en vigtig rolle i at opnå denne målsætning. Hvor de, via vurderinger af selvmordsrisikoen og efterfølgende iværksættelse af tiltag til forhindring af selvmord, kan mindske forekomsten af selvmord.

Tabel 2.2.12.1.1. Psykiatri - retningslinjer/registre

\begin{tabular}{llll}
\hline & $\begin{array}{l}\text { Forefindes der } \\
\text { opdaterede nationale } \\
\text { registre for bipolar } \\
\text { lidelse? }\end{array}$ & $\begin{array}{l}\text { Forefindes der } \\
\text { opdaterede nationale } \\
\text { registre for skizofre- } \\
\text { ni? }\end{array}$ & $\begin{array}{l}\text { Forefindes der } \\
\text { opdaterede nationale } \\
\text { kliniske retningslin- } \\
\text { jer for de store } \\
\text { sygdomme indenfor } \\
\text { psykiatri? }\end{array}$ \\
\hline Danmark (status juni, 2010) & $\mathrm{Nej}$ & $\mathrm{Ja}$ & $\mathrm{Ja}$ \\
Finland (status juni, 2010) & $\mathrm{Nej}$ & $\mathrm{Nej}$ & $\mathrm{Ja}$ \\
Færøerne (status juni, 2010) & $\mathrm{Nej}$ & $\mathrm{Nej}$ & $\mathrm{Nej}$ \\
Grønland (status juni, 2010) & $\mathrm{Nej}$ & $\mathrm{Nej}$ & $\mathrm{Ja}$ \\
Island (status juni, 2010) & $\mathrm{Nej}$ & $\mathrm{Nej}$ & $\mathrm{Nej}$ \\
Norge (status juni, 2010) & $\mathrm{Nej}$ & $\mathrm{Nej}$ & $\mathrm{Ja}$ \\
Sverige (status juni, 2010) & $\mathrm{Ja}$ & $\mathrm{Ja}$ & $\mathrm{Ja}^{*}$ \\
\hline
\end{tabular}

\footnotetext{
${ }^{\nabla}$ unipolar register under etablering; * ja, men ikke fuldstændigt ; ${ }^{\square} \mathrm{a}$, depression, emotionellt instabil personlighetsstörning, bipolär sjukdom, ätstörningar hos barn och ungdom, skitsofreni, posttraumatiskt stressyndrom, icke organisk sömnlöshet, beroendeförhållande orsakad av alkohol; $\nabla \mathrm{Ja}$, nogle diagnoser. angst og depression, og psykosociale interventioner i skizofreni

Bemærkninger:

Ingen af de nordiske lande har fuldstændige nationale register for bipolar lidelse, mens Danmark og Sverige har det for skizofreni. De 4 største nordiske lande har kliniske retningslinjer inden for psykiatri.
} 
Tabel 2.2.12.1.2 Psykiatri - tvangsindlæggelser

\begin{tabular}{lll}
\hline & $\begin{array}{l}\text { Antal tvangsindlæggelser pr. indlæggelser } \\
\text { på psykiatrisk institution/psykiatrisk afd. }\end{array}$ & $\begin{array}{l}\text { Antal tvangsindlæggelser } \\
\text { pr. 1000 indbyggere }\end{array}$ \\
\hline Danmark (2008) & 11,41 & 0,51 \\
Finland (2008) & 8,02 & 0,72 \\
Færøerne & IA & /A \\
$\begin{array}{l}\text { Grønland (2008/ } \\
\text { Dep. for sundhed }\end{array}$ & 20,41 & 0,71 \\
Island & N/A & N/A \\
Norge & N/A & N/A \\
Sverige & N/A & N/A
\end{tabular}

Kilde: ${ }^{1}$ Anvendelse af tvang i psykiatrien $2008 .{ }^{2}$ Finlands Udskrivningsregister, 2008

Bemærkninger:

Alene Danmark, Grønland og Finland har data vedr. tvangsindlæggelser og her viser resultaterne samme størrelsesorden.

Da begrebet tvangsindlæggelser ikke er defineret uddybende i forbindelse med dataindsamlingen skal der i fortolkningen tages højde for mulige forskelle i definition af tvangsindlæggelse mellem de 3 lande. 
Tabel 2.2.12.1.3 Psykiatri - ikke planlagt genindlæggelser

\begin{tabular}{|c|c|c|c|c|}
\hline & $\begin{array}{l}\text { Procentdel af } \\
\text { patienter, der } \\
\text { efterfølgende får en } \\
\text { ikke planlagt } \\
\text { genindlæggelse } \\
\text { (alle hospitaler) } \\
\text { (Cl) }\end{array}$ & $\begin{array}{l}\text { Procentdel af } \\
\text { patienter, der } \\
\text { efterfølgende får en } \\
\text { ikke planlagt } \\
\text { genindlæggelse } \\
\text { (samme hospital) } \\
\text { (CI) }\end{array}$ & $\begin{array}{l}\text { Procentdel af } \\
\text { patienter, der } \\
\text { efterfølgende får en } \\
\text { ikke planlagt } \\
\text { genindlæggelse } \\
\text { (alle hospitaler) } \\
\text { (CI) }\end{array}$ & $\begin{array}{l}\text { Procentdel af } \\
\text { patienter, der } \\
\text { efterfølgende får en } \\
\text { ikke planlagt } \\
\text { genindlæggelse } \\
\text { (samme hospital) } \\
\text { (Cl) }\end{array}$ \\
\hline & \multicolumn{2}{|c|}{ Skizofreni } & \multicolumn{2}{|c|}{ Bipolar lidelse } \\
\hline Danmark (2007) & $26,5(25,6 ; 27,5)^{1}$ & $25,3(24,4 ; 26,3)^{1}$ & $21,7(19,7 ; 23,6)^{1}$ & $20,3(18,4 ; 22,2)^{1}$ \\
\hline Finland (2007) & $39,1(37,9 ; 40,2)^{2}$ & $31,9(30,8 ; 33,0)^{2}$ & $43,1(41,4 ; 44,8)^{2}$ & $35,0(34,0 ; 36,1)^{2}$ \\
\hline Færøerne & N/A & N/A & N/A & $\mathrm{N} / \mathrm{A}$ \\
\hline Grønland & N/A & N/A & N/A & N/A \\
\hline Island & N/A & $\mathrm{N} / \mathrm{A}$ & N/A & N/A \\
\hline Norge (2007) & $\mathrm{N} / \mathrm{A}$ & $22,6(21,0 ; 24,2)^{3}$ & $\mathrm{~N} / \mathrm{A}$ & $18,4(16,6 ; 20,2)^{3}$ \\
\hline Sverige (2007) & $31,0(29,4 ; 32,6)^{4}$ & $27,0(25,6 ; 28,5)^{4}$ & $28,3(26,7 ; 29,8)^{4}$ & $25,1(23,6 ; 26,7)^{4}$ \\
\hline
\end{tabular}

Kilde: ${ }^{1}$ Dansk landspatientregister. ${ }^{2}$ Finlands Udskrivningsregister. ${ }^{3}$ Norsk patientregister. ${ }^{4}$ Svenska patientregistret

Bemærkninger:

Der er signifikante forskelle på procentdelen af patienter, der ikke planlagt genindlægges på tværs af de 4 nordiske lande, der har kunnet opgøre resultater for området, hvor det især er Finlands resultater, der afviger fra de 3 andre landes med næsten dobbelt så stor andel af uplanlagte genindlæggelser for patienter med bipolar lidelse i forhold til Norge, som har den mindste andel.

I 3 af landene (Danmark, Finland og Norge) er der desuden forskelle på procentdel af hhv. patienter med skizofreni og bipolar lidelse, der ikke planlagt genindlægges. Forskellene er dog ikke ens, hvor der i Danmark og Norge er en mindre andel af patienter med bipolar lidelse, der genindlægges uplanlagt i forhold til patienter med skizofreni. I Finland er det omvendt; en større andel af patienter med bipolar lidelse genindlægges uplanlagt.

For 3 lande er der opgjort resultat dels i forhold genindlæggelse på samme sygehus dels genindlæggelse på alle hospitaler. Resultaterne for Sverige og Finland viser her signifikante forskelle i resultater baseret på de 2 opgørelsesmetoder, hvilket kunne indikerer, at deres tilrettelæggelse af behandlingen afviger fra Danmarks. 
Tabel 2.2.12.1.4 Psykiatri - ventetider

\begin{tabular}{ll}
\hline & $\begin{array}{l}\text { Procentdel af patienter med ventetid til behandling over 90 dage, børne- og } \\
\text { ungdomspsykiatri (Cl) }\end{array}$ \\
\hline Danmark (2008) & $39^{1}$ (NA) \\
Finland & N/A \\
Færøerne & Kan ikke opgøres meningsfuldt, da der kun er besøg af børnepsykia- \\
trisk konsulent 2 gange årligt i Grønland \\
for sundhed)
\end{tabular} $\begin{aligned} & \text { Island } \\
& \text { Norge (2009) } \\
& \text { Sverige (2009) }\end{aligned}$

Kilder. ${ }^{1}$ Udviklingen i den børne- og ungdomspsykiatriske virksomhed. ${ }^{2}$ Norsk patientregister. ${ }^{3}$ Sveriges Kommuner och Landstings databas "Väntetider i Vården."

\section{Bemærkninger}

Danmark, Norge og Sverige har opgjort resultater for ventetid fra henvisning til behandling på mere end 90 dage. Disse resultater viser ganske markante forskelle i procentdelen af børn og unge, der venter mere end 3 måneder på behandling. Hvor der er fire gange flere danske børn og unge, der venter i mere end 90 dage end svenske børn.

Der er ikke opgjort konfidensintervaller til resultaterne, men givet at de dækker et helt år og landenes størrelse taget i betragtning, må de antages at være statistisk signifikante. Disse forskelle kalder på en undersøgelse af, hvorvidt behandlingen er tilrettelagt så ensartet, at sammenligningen er meningsfuld samt hvorvidt, der er forskelle i andelen af befolkningen, der henvises til behandling i de 3 lande. 
Tabel 2.2.12.1.5 Psykiatri - selvmord

\begin{tabular}{|c|c|c|c|c|c|c|}
\hline & $\begin{array}{l}\text { Andel } \\
\text { selvmord, } \\
\text { indenfor } 1 \\
\text { år blandt } \\
\text { patienter, } \\
\text { der har } \\
\text { været } \\
\text { indlagt for } \\
\text { skizofreni } \\
\text { (Cl) }\end{array}$ & $\begin{array}{l}\text { Andel } \\
\text { selvmord, } \\
\text { indenfor } 30 \\
\text { dage blandt } \\
\text { patienter } \\
\text { der har } \\
\text { været } \\
\text { indlagt for } \\
\text { bipolar } \\
\text { lidelse (Cl) }\end{array}$ & $\begin{array}{l}\text { Andel } \\
\text { selvmord, } \\
\text { indenfor } 1 \\
\text { år blandt } \\
\text { patienter, } \\
\text { der har } \\
\text { været } \\
\text { indlagt for } \\
\text { bipolar } \\
\text { lidelse }(\mathrm{Cl})\end{array}$ & $\begin{array}{l}\text { Andel } \\
\text { selvmord, } \\
\text { indenfor } 30 \\
\text { dage blandt } \\
\text { patienter, } \\
\text { der har } \\
\text { været } \\
\text { indlagt for } \\
\text { depression } \\
\text { (Cl) }\end{array}$ & $\begin{array}{l}\text { Andel } \\
\text { selvmord, } \\
\text { indenfor } 1 \\
\text { år blandt } \\
\text { patienter, } \\
\text { der har } \\
\text { været } \\
\text { indlagt for } \\
\text { depression } \\
\text { (Cl) }\end{array}$ & $\begin{array}{l}\text { Selvmord, } \\
\text { befolk } \\
\text { ningen } \\
\text { pr. } 100.000 \\
\text { indbygger } \\
\text { (Kvinder I } \\
\text { Mænd) }\end{array}$ \\
\hline $\begin{array}{l}\text { Danmark } \\
\text { (2006) }\end{array}$ & $\mathrm{N} / \mathrm{A}$ & N/A & N/A & N/A & $\mathrm{N} / \mathrm{A}$ & $6,5 / 17,5^{4}$ \\
\hline $\begin{array}{l}\text { Finland } \\
(2007)\end{array}$ & N/A & N/A & N/A & N/A & $\mathrm{N} / \mathrm{A}$ & $9,0 / 28,9^{4}$ \\
\hline $\begin{array}{l}\text { Færøerne } \\
(2002-06)\end{array}$ & 0 (NA) & 0 (NA) & 0 (NA) & $0(\mathrm{NA})$ & 0 (NA) & $0,9 / 1,6^{4}$ \\
\hline $\begin{array}{l}\text { Grønland } \\
\text { (2005) }\end{array}$ & N/A & N/A & N/A & N/A & N/A & $86,3 / 89,1^{4}$ \\
\hline $\begin{array}{l}\text { Island } \\
\text { (2007) }\end{array}$ & N/A & N/A & $\mathrm{N} / \mathrm{A}$ & N/A & N/A & $6,6 / 18,9^{4}$ \\
\hline $\begin{array}{l}\text { Norge } \\
(2006)\end{array}$ & N/A & N/A & $\mathrm{N} / \mathrm{A}$ & $\mathrm{N} / \mathrm{A}$ & $\mathrm{N} / \mathrm{A}$ & $6,0 / 16,8^{4}$ \\
\hline $\begin{array}{l}\text { Sverige } \\
\nabla(2009) \\
*(2007) \\
(2008)\end{array}$ & $0,6 \%{ }^{2 \star}(\mathrm{NA})$ & $0,4 \%^{2 *}(N A)$ & $1,1 \%^{2^{*}}(\mathrm{NA})$ & $0,5 \%^{2^{2}(N A)}$ & $1,4 \%^{2^{\star}}(\mathrm{NA})$ & $\begin{array}{l}7,1 / 17,6^{* 4} \\
16,0^{-3}\end{array}$ \\
\hline
\end{tabular}

Kilder: ${ }^{1}$ Finlands Udskrivningsregister 2008. ${ }^{2}$ Patientregistet, Sverige 2007 og dødsårsagsregistret 2007-2008.

${ }^{3}$ Sveriges dødsårsagsregister 2008. ${ }^{4}$ Health Statistics in the Nordic Countries 2007

Bemærkninger:

Alene Sverige og Færøerne har kunnet opgøre resultater vedrørende selvmord, og da resultater fra Færøerne og Sverige ikke er sammenlignelige grundet Færøernes lille datagrundlag jf. de indledende kommentarer, er det ikke muligt at konkludere noget ud for disse resultater om forskelle mellem landene. Der er ikke konfidensintervaller på resultaterne for de forskellige lidelser, så mens tallene viser, at flere patienter med depression efterfølgende begår selvmord end patienter med bipolar lidelse og skizofreni, et det ikke muligt at konkludere, om forskellene er signifikante.

For at kunne relatere selvmord til behandlingsindsatsen anbefales, at opgørelser af selvmordsfrekvens sker på diagnoseniveau (10). 
Tabel 2.2.12.2 Potentielle indikatorer vedrørende psykiatri

\begin{tabular}{ll}
\hline Indikatornavn & Definitioner \\
\hline Psykiatri & Kvalitetsindikatorer \\
ICD 10 - & Der bør udvikles fælles nordiske indikatorer der belyser, om patienten får den rette \\
Diagnosekode: & diagnostik og behandling i overensstemmelse med nationale kliniske retningslinjer \\
F10-19, & Eksempler på indikatorer: \\
F20-39 & Andel af patienter med skizofreni som har tilknyttet et fast medlem af behand- \\
& lerteamet \\
& $\begin{array}{l}\text { Andel af patienter med skizofreni, der modtager psykoedukation i manualisere- } \\
\text { de forløb }\end{array}$ \\
& Andel af patienter med skizofreni og pårørende, der får tilbudt psykoedukativ \\
& familieintervention \\
& Andel af patienter med skizofreni, der er undersøgt for selvmordsrisiko \\
& Andel patienter med undvikbar slutenvård pr. 100 000 invånara \\
& Andel psykiatriske patienter med unødig indlæggelse i somatisk vård \\
& Andel patienter i psykiatrisk vård med misbrugsproblemer \\
\hline
\end{tabular}

\subsubsection{Generiske indikatorer}

\subsubsection{Begrundelse for valg af område}

Generiske indikatorer er udvalgt mhp. at belyse væsentlige aspekter af kvaliteten i hele sundhedsvæsnet - betragtet som system. Indikatorsættet omfatter tilgængelighed, sammenhæng og optimal anvendelse af vidensbaserede interventioner. Vurdering af tilgængelighed sker via borgervurdering (survey).

Vurdering af kvaliteten og effektivitet af sammenhæng mellem primær og sekundærsektor sker via genindlæggelseshyppighed (11) og hyppighed af forebyggelige indlæggelser. Mens vurdering af optimal anvendelse af tilgængelig viden om behandlings- og forebyggelsesinterventioner sker via mortalitetsrater omfattende behandlelige eller forebyggelige dødsårsager $(12,13)$. Følgende indikatorer er vedtaget blandt de generiske:

- Procentdel, der afholdt sig fra at søge behandlingshjælp trods behovet, pga. manglende adgang - pga. ventetider/ økonomiske hensyn etc.

- Procentdel, der afholdt sig fra at søge behandlingshjælp trods behovet pga. anden grund end manglende adgang, f.eks. manglende tid/lyst.

Disse data indsamles i regi af EU (Eurostat), men da der her advares om, at data ikke skal bruges til at foretage internationale sammenligninger, er de valgt udeladt i indeværende rapport. 
Tabel 2.2.13.1.1. Generiske indikatorer

\begin{tabular}{|c|c|c|c|c|}
\hline & $\begin{array}{l}\text { Antallet af fore- } \\
\text { byggelige indlæg- } \\
\text { gelser pr. } 100000 \\
\text { indbyggere }\end{array}$ & $\begin{array}{l}\text { Procentdel af } \\
\text { udskrevne patien- } \\
\text { ter, der genind- } \\
\text { lægges }\end{array}$ & $\begin{array}{l}\text { Dødsfald pr. } \\
100.000 \text { indbygge- } \\
\text { re, som kunne } \\
\text { have været } \\
\text { forhindret via } \\
\text { forebyggelse og } \\
\text { behandling } \\
\text { (sundhedssystem) }\end{array}$ & $\begin{array}{l}\text { Dødsfald pr. } \\
100.000 \text { indbygge- } \\
\text { re, som kunne } \\
\text { have været forhin- } \\
\text { dret via behand- } \\
\text { lingstiltag }\end{array}$ \\
\hline $\begin{array}{l}\text { Danmark } \\
\star(2008) \\
\nabla(2002-04)\end{array}$ & N/A & $9,2 \%(\mathrm{~N} / \mathrm{A})^{2}$ & $72-76^{\nabla 5}$ & N/A \\
\hline Færøerne & N/A & N/A & N/A & N/A \\
\hline Grønland & N/A & N/A & N/A & N/A \\
\hline Island & N/A & N/A & N/A & N/A \\
\hline Finland & N/A & N/A & N/A & N/A \\
\hline Norge (2007) & 1823,13 & N/A & N/A & N/A \\
\hline $\begin{array}{l}\text { Sverige } \\
{ }^{*}(2005) \\
\nabla(2008) \\
(2005-08)\end{array}$ & $1169,6^{\nabla 4}$ & N/A & $44,1^{\square 4 \diamond}$ & $45,8^{-4 \diamond}$ \\
\hline
\end{tabular}

Kilder: ${ }^{2} \varnothing$ get fokus på de gode resultater - juni 2010 indenrigs og sundhedsministeriet. ${ }^{3}$ Norsk patientregister.

${ }^{4}$ Svenska patientregistret (indläggelser) och Dödsorsaksregistret (dödsfald som kunne väret forhindret). 5 Eurostat population and social conditions

Bemærkninger:

Danmark og Sverige oplyser, at dødsfald, der kunne være forhindret, er opgjort ved forskellige metoder. Samtidig er den afhængig af, hvorledes dødsfald kodes, og her kan der erfaringsmæssigt være forskelle, der ikke handler om årsagerne til død. Resultaterne for de 2 lande kan dermed ikke sammenlignes meningsfuldt (14.)

Der er derudover kun ganske få lande, der har kunnet levere data vedr. generiske indikatorer, og der kan ikke kommenteres eller fortolkes meningsfuldt på disse.

Tilgængelighed vurderet via surveydata skal fortolkes med stor forsigtighed - Eurostat fraråder jf. ovenfor anvendelse til national benchmarkning på grund af nationalt betingede kulturelle forskelle mellem landene. Resultaterne af opgørelserne vedrørende genindlæggelser, forebyggelige indlæggelser og forebyggelige dødsfald skal ligeledes vurderes med forsigtighed på baggrund af mulige forskelle i opgørelsesmetode og kodepraksis i de nationale patientregistre. 
Tabel 2.2.13.2. Potentielle indikatorer vedrørende generiske behandlings- og plejeområder

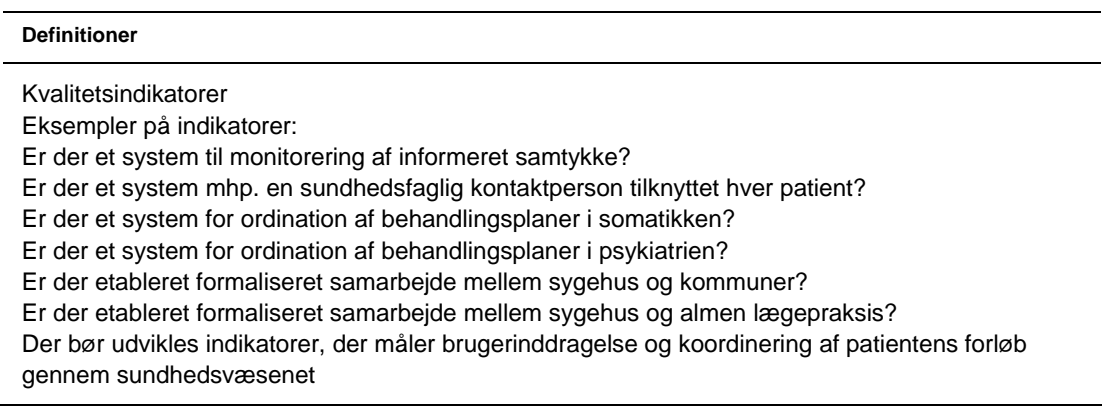

\subsection{Diskussion}

Projektgruppen har valgt en række indikatorer, hvor det har vurderedes, at der aktuelt har kunnet indsamles relevante data. Herudover har projektgruppen udarbejdet og videreudviklet potentielle indikatorer, som vurderes at kunne indgå i sammenligninger og benchmarking mellem de nordiske lande fremover.

Resultaterne viser, at det på en lang række områder er muligt at tilvejebringe data, som muliggør sammenligning på tværs af de nordiske lande, mens der på andre områder kun i beskedent omfang findes data. Dette betyder, at der på en række områder er fortsat behov for at videreudvikle fællesnordiske kvalitetsindikatorer.

Dette gælder eksempelvis i relation til psykiatri, hvor der er behov for at udvikle kvalitetsindikatorer, der belyser patienternes forløb i sundhedsvæsenet, samt sundhedsfremme og forebyggelse, hvor der er behov for flere data vedrørende levevilkår og levestandard.

Indenfor sundhedsfremme og forebyggelse samt børn og unge er der ligeledes betydelige vanskeligheder med retvisende tolkninger og konklusioner. Disse områder bør derfor videreudvikles i specifikke nordiske projekter.

Arbejdsgruppen ønskede at inddrage indikatorer til belysning af kvaliteten af sundhedsvæsenets ydelser i den primære sundhedstjeneste i relation til de valgte fokusområder. Dette har imidlertid ikke været muligt, idet der ikke kunne identificeres sammenlignelige data på nationalt niveau i de nordiske lande. Dette indebærer, at det ikke er muligt at belyse kvaliteten af sundhedsvæsenets ydelser på området nationalt i de nordiske lande. Dette er tankevækkende i betragt- 
ning af, at den største andel af sundhedsvæsenets ydelser leveres i det primære sundhedsvæsen. Dette betyder, at der er behov for en målrettet indsats i de nordiske lande, såfremt dokumentation af kvaliteten af sundhedsvæsenets ydelser samt benchmarking mellem de nordiske lande skal muliggøres.

I projektforløbet har projektgruppen desuden haft særlige områder i fokus, det gælder monitorering af genindlæggelser, hvor det har vist sig, at der ikke i de nordiske lande er sammenlignelige data, idet der enten registreres på forskellig måde, eller at genindlæggelser ikke registreres. Genindlæggelser indenfor 30 dage efter udskrivelse anses som et vigtigt parameter, når kvalitetsmål skal vurderes.

Desuden har projektgruppen haft særligt fokus på ventetider generelt for patienter og i forhold til sygdomsgrupper. Heller ikke her har de nordiske lande i dag sammenlignelige data, idet ventetid opgøres forskelligt. Her kan blive tale om et udviklingpotentiale i forhold til „hospital delay“, „doctors delay“ og „patient delay“.

Endelig har projektgruppen haft særligt fokus på lighed og ulighed i sundhed, herunder i behandling og pleje.

Behandling og pleje på lige vilkår indebærer, at alle medborgere har lige ret til behandling og pleje, og at denne skal tilbydes på lige vilkår uanset alder, køn, seksuel orientering, funktionsniveau, boligforhold, uddannelse, social stilling, fødeland eller religiøs tilknytning. Lighed i behandling og pleje forudsætter, at behovet for behandling er grundlaget for prioriteringer mellem personer og grupper af medborgere.

Da alle mennesker ikke er lige vedrørende sundhed, bør et sundhedsvæsen, som stræber efter at opnå sundhed og behandling og pleje på lige vilkår for hele befolkningen, prioritere sundhedsfremmende og forebyggende indsatser.

I dette arbejde har projektgruppen ikke identificeret fælles indikatorer, som belyser sådanne indsatser. Det er ønskværdigt i fremtiden at kunne arbejde med lighedsaspekter i nordiske sammenligninger, såfremt datatilgængeligheden tillader det.

For nærmere uddybning af hvilke grundlag landene i dag har for registrering, er der i bilag 3 en oversigt over nationale kliniske kvalitetsdatabaser og nationale kliniske retningslinjer for de prioriterede indikatorer, ligesom der er oversigt over kliniske kvalitetsdatabaser og nationale kliniske retningslinjer for børn- og ungeområdet. Endelig er der en oversigt i bilag 3 der viser tilgængelige screeningsprogrammer.

I bilag 4 er der beskrevet lovgrundlag for indsamling og offentliggørelse af data for Danmark, Finland, Grønland, Norge og Sverige. 


\section{Referencer}

(1) Barry, MJ., "Screening for Prostate Cancer - The Controversy That Refuses to Die”, N. Engl. J Med, 360; 13, 2009;

(2) Tretli S, Engeland A, Haldorsen T, Hakulinen T, Hörte LG, Luostarinen T, Schou G, Sigvaldason H, Storm HH, Tulinius H, Vaittinen P., "Prostate Cancer — Look to Denmark?”, J Natl Cancer Inst. 1996 Jan 17;88(2):128)

(3) OECD, Health at a Glance, 2009

(4) Köster M., Andersson J., Carling K, Rosén M, ”Dödlighet efter hjärtinfarkt har minskat i nästan alla landsting under 1990-talet,” Läkartidningen, 2003, no37, pp. 2838-2844.

(5) Johnsen SP, Overvad K, Sørensen HT, Tjønneland A, Husted SE, Predictive value of stroke and transient ischemic attack discharge diagnoses in The Danish National Registry of Patients, J Clin Epidemiol,2002 Jun;55(6):602-7)

(6) Det nationale indikatorprojekt, Danmark, dokumentalistrapport for området fødsler, 2010
(7) WHO: The European Health Report 2005 p. 32

(8) OECD. Health Care Indicator project. DELSA/ELSA/WD/http (2004)16 p. 17

(9) OECD. Health Care Indicator project DELSA/ELSA/WD/-HTP(2004)16

(10) Nordentoft, M, Prevention of suicide and attempted suicide in Denmark, Epidemiological studies of suicide and intervention studies in selected risk groups, 'Dan Med Bull', 2007; Nov; 54(4): 306-69

(11) Indenrigs- og Sundhedsministeriet (Danmark), Øget fokus på de gode resultater, juni 2010

(12) Nolte, E. McKee, M, Does Health Care Save Lives? Avoidable mortality revisited, 2004;

(13) Vinge S. \& Buch, M.S., Uhensigtsmassige indlaggelser - muligheder og perspektiver for kommunerne, marts 2007

(14) Socialstyrelsen, Quality and Efficiency in Swedish Health Care, Regional Comparisons, 2007) 



\section{Kapitel}

\subsection{Kvalitetsindikatorer för mun- och tandhälsovården}

\subsubsection{Arbetsgruppens målsättning}

Den primära målsättningen har varit att utreda behovet av samnordiska kvalitetsindikatorer för mun- och tandhälsovården, och att kartlägga vilka indikatorer som redan används i Norden. Därefter skulle arbetsgruppen ta fram ett förslag till gemensamma nordiska kvalitetsindikatorer. Den sekundära målsättningen har varit att de valda indikatorerna ska kunna användas för jämförelser i ett nordiskt perspektiv och bidra till en gemensam nordisk profilering $\mathrm{i}$ ett europeiskt sammanhang. I arbetet skulle OECD:s kvalitetsindikatorprojekt (OECD Health Care Quality Indicators Project) och EGOHID-projekt (European Global Oral Health Indicators Development) beaktas.

\subsubsection{Inledning}

Mun- och tandhälsan är en viktig del av den allmänna hälsan och välbefinnandet. Trots att tandsjukdomarna i hög grad kan förebyggas, är de vanliga i Norden (WHO, 2003) och utgör ett folkhälsoproblem. Kostnaderna för tandvård är höga både för den enskilde och för samhället.

Grunden för den allmänna hälsovården i Norden är, att alla medborgare har rätt till vård på lika villkor. Att kunna utvärdera vårdkvaliteten blir allt viktigare för såväl patienter som vårdgivare, administratörer, finansiärer och köpare av vård. Projektet föranleddes av bristen på gemensamma kvalitetsindikatorer i Norden, även om kvalitetsarbete inriktat på tandhälsa har utförts i respektive land. 


\subsubsection{Arbetsgruppens organisation och projekthantering}

Det nordiska projektet kring kvalitetsindikatorer för mun- och tandhälsovården startade under det finländska ordförandeskapet i Nordiska ministerrådet i oktober 2007. De nordiska länder som deltagit i projektet är Danmark, Färöarna, Finland, Island, Norge och Sverige. Projektet har finansierats av Nordiska ministerrådet, de deltagande länderna samt Social- och hälsovårdsministeriet i Finland.

Arbetsgruppen var organiserad på följande sätt:

Danmark:

Lene Vilstrup (lvi@sst.dk) og Lisa Bøge Christensen (lbch@sund.ku.dk)

Finland:

Anne Nordblad, projektledare (anne.nordblad@stm.fi), Leena Nuorteva, projektkoordinator (leena.nuorteva@thl.fi), Annamari Nihtilä, ansvarig för rapportering, (annamari.nihtila@helsinki.fi) och Kaj Rönnberg (kaj.ronnberg@espoo.fi)

Färöarna:

Sigrid Arge (sigrid@torshavn.fo) og Bergtóra Hanusardóttir (bergtora @post.olivant.fo)

Island:

Helga Ágústsdóttir (helga.agustsdottir@hbr.stjr.is)

Norge:

Maren Mathiesen Wilberg (Maren.Mathiesen.Wilberg@helse-dir.no), Trond Ekornrud (trond.ekornrud@ssb.no), Lise Lund Håheim (Lise.Lund.Haheim @kunnskapssenteret.no) Tidigare deltagare: Andreas Hedum (SSB) och Jørgen Underthun (Helsedirektoratet)

Sverige:

Marianne Appelquist (marianne.appelquist@socialstyrelsen.se) och Andreas Cederlund (andreas.cederlund@socialstyrelsen.se) (se bilag 7 for yderligere information).

Finland har fungerat som projektledare och koordinator. Åtta möten har hållits: Sex i Finland, ett i Sverige och ett i Danmark. 
En mer omfattande rapport från arbetsgruppen som bland annat beskriver tandvårdstjänsterna i Norden, kvalitetsarbetet inom mun- och tandhälsovården i Norden, de valda indikatorerna med detaljerad information om datakällorna finns på www.thl.fi/fi_FI/web/fi/tutkimus-/julkaisut/verkko-julkaisut.

\subsubsection{Principerna för valet av kvalitetsindikatorerna för mun- och tandhälsovården}

Målet för projektet har varit att ta fram ett förslag till gemensamma nordiska kvalitetsindikatorer för mun- och tandhälsovården. Enligt rekommendationerna för de europeiska hälsoindikatorerna (European Community Health Indicators ECHI) ska indikatorerna

- vara begreppsmässigt konsekventa

- ta hänsyn till politikprioriteringar inom tandhälsovården

- vara vetenskapligt valida, tillförlitliga och relevanta.

OECD:s kvalitetsindikatorprojekt och det ramverk, som utvecklats av projektet, användes som utgångspunkt vid valet av indikatorer (Figur 1). Ramverket framhäver att målet för hälsovårdssystemen är att förbättra befolkningens hälsotillstånd, som påverkas av flera faktorer. Exempel på sådana faktorer är den sociala, ekonomiska och fysiska miljö, som människor lever i samt enskilda livsstilar och beteendemässiga faktorer.

Hälsovårdssystemens insatser bidrar också till befolkningens hälsotillstånd (Health at a Glance: OECD Indicators, 2009). I den senaste OECD-rapporten (2009) togs följande tandhälsoindikatorer upp: tandhälsa bland barn, antal tandläkare och ojämlikhet i antalet tandläkarbesök. Dessa indikatorer har tagits i beaktande vid urvalet av de nordiska indikatorerna.

Resultaten från det tidigare genomförda EGOHID-projektet har också utnyttjats i detta projekt. De viktiga tandhälsoindikatorer, som EGOHIDprojektet rekommenderar, finns dokumenterade i rapporten: "Health Surveillance in Europe. A Selection of Essential Oral Health Indicators” 2005 Catalogue (www.egohid.eu).

I denna rapport har de valda indikatorerna delats in i struktur-, processoch resultatindikatorer samt potentiella indikatorer. Indikatorerna beskrivs utifrån dessa kategorier. 
Enligt OECD-rekommendationerna består varje indikatorbeskrivning av följande fält:

1. Titel, 2. Indikatorns relevans, 3. Indikatorns vetenskapliga stringens, 4. Slutsatser, 5. Definitioner och avvikelser

Figur 1. Visar hur de valda nordiska kvalitetsindikatorerna för mun- och tandhälsovården överensstämmer med OECD:s konceptuella ramverk.
Hälsotillstånd
1. Andel kariesfria av undersökta barn och ungdomar
2. Medelvärdet för DMFT* hos undersökta barn och ungdomar
3. SiC-index ${ }^{\star *}$
4. Andel (\%) tandlösa 65-74-åringar i befolkningen
5. Andel (\%) 65-74-åringar som har minst 20 kvarvarande tänder i munnen

\begin{tabular}{|l|}
\hline Hälsovårdssystemens prestationer: kvalitet, tillgänglighet, kostnader/utgifter \\
1. Tandvårdskostnader per invånare \\
2. Andel (\%) av befolkningen som har besökt tandvården inom ett år \\
Hälsovårdsresurser och aktiviteter \\
1. Antal invånare per legitimerad tandvårdspersonal under pensionsåldern \\
2. Antal invånare per yrkesaktiv tandvårdspersonal under pensionsåldern \\
3. Antal tandläkare under pensionsåldern per tandvårdspersonal \\
2. Konsumtion av läskedrycker
\end{tabular}

Källor: OECD (2009); Health at a Glance and WHO (1997); Oral health surveys, Basic Methods

Noter

${ }^{*}$ DMFT = Decayed, Missing and Filled Teeth,

${ }^{*} \mathrm{SIC}=$ Significant Caries Index.

\subsubsection{Indikatorer och datainsamling}

\subsubsection{Strukturindikatorer}

Tandvårdspersonal

1. Antal invånare per legitimerad tandvårdspersonal under pensionsåldern

2. Antal invånare per yrkesaktiv tandvårdspersonal under pensionsåldern

3. Antal tandläkare under pensionsåldern per tandvårdspersonal. 
Indikatorns relevans

Som Världshälsoorganisationen har betonat kan hälsovårdssystemens struktur ses som en huvudfaktor för effektiv styrning, och den har en avgörande betydelse för att uppnå målen för hälsovårdssystemen: att förbättra hälsan och att leva upp till befolkningens legitima förväntningar när det gäller vårdkvalitet och rättvis finansiering. Det är därför i detta sammanhang viktigt att kartlägga och följa upp antalet yrkesverksamma. Det är också av stor vikt att hälsovårdssystemen anpassas efter framtidens behov.

Indikatorns vetenskapliga stringens

Det övergripande målet för arbetskraftsplaneringen är att se till, att det finns tillräckligt med personal med lämplig kompetents för att kunna tillgodose befolkningens vårdbehov, samt att se till att personalen är tillgänglig och rätt fördelad mellan olika geografiska regioner, inrättningar och vårdnivåer (primär, sekundär och tertiär) (WHO, 2000).

\section{Slutsatser}

Antalet legitimerade tandläkare och tandhygienister framgår av Figur 2. Det finns behov av mer information om den yrkesaktiva personalen. I t.ex. Sverige är det stor skillnad mellan antalet invånare per legitimerad tandläkare (838) och antalet invånare per yrkesaktiv tandläkare (1 234), eftersom många legitimerade tandläkare arbetar utomlands. Det finns avsevärda skillnader i totala antalet legitimerade tandläkare per legitimerade specialisttandläkare: i Danmark 24,0 och i Finland 6,3. Skillnaderna beror främst på, att antalet erkända specialiteter varierar mellan de nordiska länderna. Ytterligare information finns i en mer omfattande rapport på. www.thl.fi/fi_FI/web/fi/tutkimus/julkaisut/verkkojulkaisut.

Definitioner och avvikelser

Legitimerad tandläkare: En person som har avlagt tandläkarexamen och är legitimerad att självständigt utöva tandläkaryrket (WHO, 2000).

Yrkesverksam tandläkare: Legitimerad tandläkare som faktiskt utövar yrket.

Legitimerad tandhygienist: En person som har slutfört en grundläggande tandhygienistutbildning, och som i sitt eget land är kvalificerad och behörig att arbeta som tandhygienist.

Yrkesverksam tandhygienist: Legitimerad tandhygienist som faktiskt utövar yrket. 
Det kan finnas skillnader i arbetskraftsindikatorerna beroende på olika pensionsåldrar i de olika länderna. Antalet erkända specialiteter varierar från två (ortodonti, oral kirurgi) i Danmark till åtta i Sverige, vilket förklarar skillnader i de nordiska talen. Däremot jämförelser av antalet invånare per specialist inom ortodonti och oral kirurgi är mera jämförbara mellan de nordiska länderna.

Figur 2. Antal invånare/legitimerade tandläkare under pensionsåldern och antal invånare/legitimerade tandhygienister under pensionsåldern

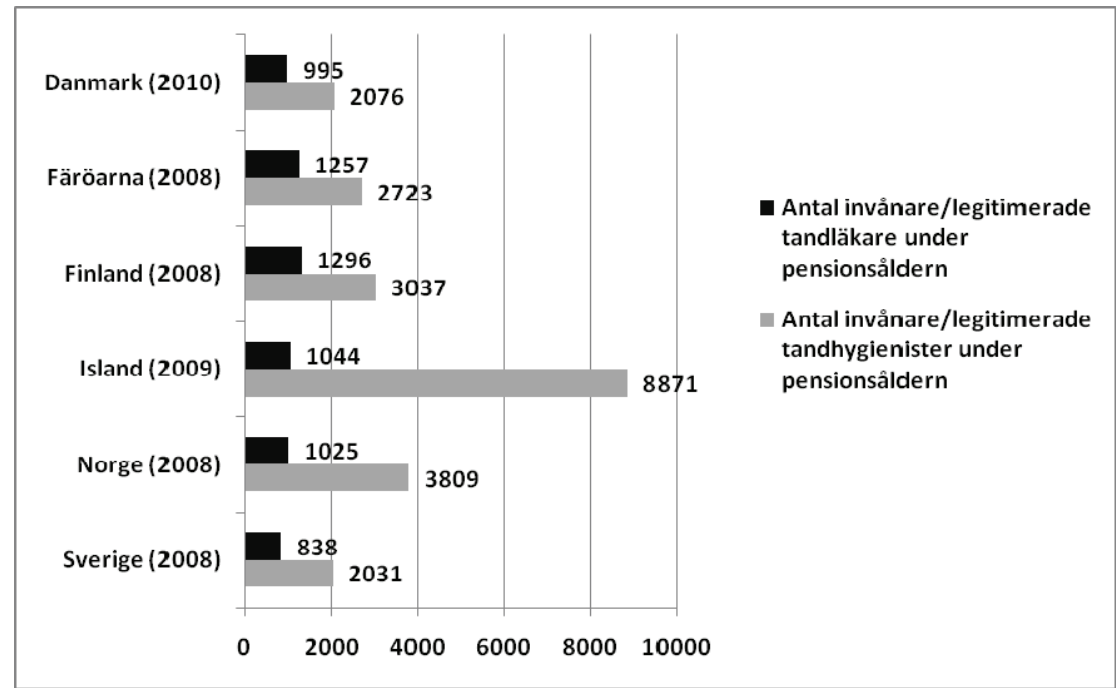

Källa: www.thl.fi/fi_Fl/web/fi/tutkimus/julkaisut/verkkojulkaisut

\subsubsection{Tandvårdskostnader per invånare}

Indikatorns relevans

Skillnaderna i tandvårdskostnader per invånare avspeglar en mängd marknads- och sociala faktorer, liksom hälsovårdssystemens olikartade finansierings- och organisationsstrukturer i de olika länderna.

Indikatorns vetenskapliga stringens

Den här indikatorn kan användas för komparativ analys av olika mun- och tandhälsovårdens system. I egenskap av ekonomisk indikator ger den information om olika sätt att organisera, finansiera och tillhandahålla hälsotjänster samt om huvudaktörernas roller i hälsosystemen. Den ger också information om kostnaderna för tandvårdstjänster, beskriver den institutionella ramen, och belyser förloppet av innehållet i och implementeringen av hälsovårdsreformer (WHO, 1998). 
Slutsatser

Tandvårdskostnaderna per invånare i de nordiska länderna varierade mellan 217 euro (Danmark, år 2005) och 269 euro (Island, år 2008) med undantag av Finland, där den totala kostnaden per invånare år 2007 var så låg som 133 euro. När det gäller tandhälsovård är arbetskostnaderna av stor betydelse. I Finland har antalet tandläkare minskat, och detta kan medföra lägre arbetskostnader. Även lönenivån i Finland har varit lägre än i de andra nordiska länderna (t.ex. OECD-jämförelser för läkare och sjukskötare).

När det gäller kostnader för offentlig tandvård per invånare, är skillnaderna mindre, högst i Danmark 84 euro (år 2005) och lägst på Island 49 euro (år 2008).

Definitioner och avvikelser

Indikatorn definieras som totala tandvårdskostnader - offentliga och privata per år och invånare.

Totala tandvårdskostnader mäter den slutliga konsumtionen av varor och tjänster (dvs. aktuell vårdkostnad) plus investeringar i infrastruktur inom tandhälsovården. Detta innefattar både offentliga och privata utgifter för tandvård (tjänster och varor), offentliga hälsovårds- och preventions-projekt samt administration. Ländernas hälsovårdskostnader har räknats om till en gemensam valuta (euro).

Processindikatorer

Andel (\%) av befolkningen som har besökt tandvården inom ett år

Indikatorns relevans

Indikatorn beskriver besöksmönstret och utnyttjandet av tandvårdsresurserna under ett kalenderår. Mönstret för utnyttjande av tandvårdstjänster är kulturbetingat och varierar länderna emellan. Indikatorn kan användas i nordisk jämförelse närmast som ett mått på resursutnyttjande.

I dagsläget är målet inte att hela befolkningen skall besöka tandvården årligen utan enligt individuellt behov. Eftersom uppgifter om årlig tandvårdskontakt fanns att få från nästan alla nordiska länder, valdes detta som en indikator. Det är viktigt att utveckla statistiken i respektive land, så att man längre fram kan ha utnyttjande av mun- och tandhälsovårdens tjänster under en längre tidperiod som indikator. 
Indikatorns vetenskapliga stringens

Indikatorn baseras på registerdata och enkätstudier i de nordiska länderna. Mer information finns på www.thl.fi/fi_FI/web/fi/tutkimus/julkaisut/ verkkojulkaisut

Slutsatser

Fem länder (Danmark, Färöarna, Finland, Island och Norge) kan rapportera den andel av befolkningen under 18/19/20 år som har besökt tandvården inom ett år och siffrorna varierade från 61 \% på Island till 77 \% i Finland och Danmark. För den vuxna befolkningen finns data tillgängliga för Danmark (64 \%), Finland (50 \%), Norge (76 \%) och Sverige (56 \%) (Figur 3).

Definitioner och avvikelser

Indikatorn visar den andel av befolkningen (barn och ungdomar under 18/19/20 år samt vuxna 18/19/20 år och äldre separat), som besökte tandvården inom en period av ett år. Danmark ger en uppskattning av antalet barn, ungdomar och vuxna som fick subventionerad tandvård under 2009. För Färöarna avser siffran barn och ungdomar under 16 år. Uppgifterna för Finlands del (åldersgrupperna 0-18 år samt vuxna) är för den privata sektorn inhämtade från FPA (Folkpensionsanstalten) och för den offentliga sektorn från officiell nationell statistik (Institutet för hälsa och välfärd, THL).

I Finland kan viss överlappning i statistiken förekomma. Uppgifterna om utnyttjandet av tandvård för barn i åldern 0-18 på Island kommer från det nationella försäkringssystemet (Sjúkratryggingar Î́lands). Norge uppger data för vuxna i åldern 21 eller äldre, och dessa uppgifter härrör från hushållsenkäter. För barn och ungdomar kommer data från Kommun-stat-rapporteringen (KOSTRA) och åldersgruppen är 3-18 år. För Sveriges del består uppgifterna av registerdata, som omfattar personer i åldrarna 20 år eller äldre. Skillnader i enkätfrågor och svarskategorier påverkar tvärnationella jämförelser. 
Figur 3. Andel av befolkningen under 18/19/20 år och andelen vuxna i åldern 18/19/20 år eller äldre som besökte tandvården inom en period av ett år, \%

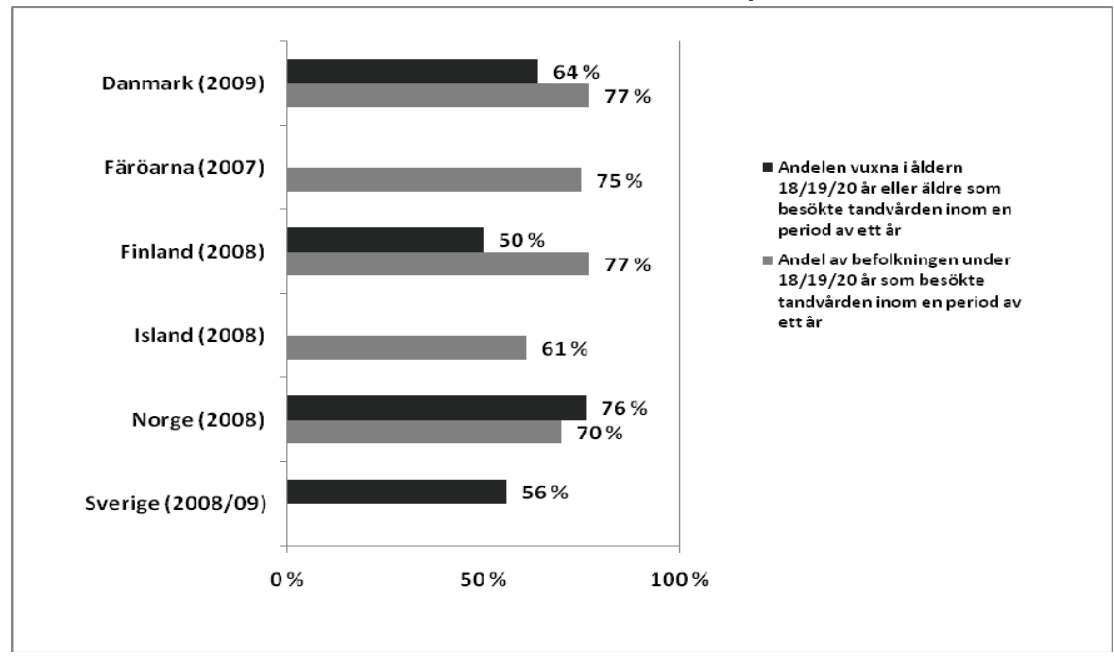

Källa: www.thl.fi/fi_Fl/web/fi/tutkimus/julkaisut/verkkojulkaisut

Hälsobeteende hos barn och ungdomar

För alla länder utom Färöarna kommer informationen och data från WHO:s HBSC-studie. (Health behaviour in school-aged children 2005/2006). Data för Färöarna är från en senare (2009) studie baserad på självifyllda fråge-formulär.

\subsubsection{Tandborstningsfrekvens (mer än en gång per dag)}

Indikatorns relevans

De två viktigaste tandsjukdomarna - karies och parodontit - kan ses som beteende beroende sjukdomar, som effektivt kan förebyggas genom god munhygien och begränsningar i sockerintaget (mängd och frekvens).

Upplevd renlighet och hygien är viktiga motiverande faktorer för regelbunden tandborstning (Macgregor IDM et al., 1997). Tandborstning har satts i sammanhang med självkänsla och känslan av att ha kontroll över den egna hälsan (McGrath C och Bedi R, 2000).

Tidigare resultat från HBSC-studien visar att regelbunden tandborstning är vanligare hos flickor, hos ungdomar i familjer med högre inkomster samt hos dem vars föräldrar har högstatusyrken (Maes L et al., 2006). 
Indikatorns vetenskapliga stringens

Tandborstning anses vara en viktig metod för att hålla tandköttet friskt och minska plackbildningen, särskilt när den kombineras med fluortandkräm. Den universellt rekommenderade frekvensen för tandborstning är två gånger per dag (Löe H, 2000).

\section{Slutsatser}

Det finns stora variationer mellan de nordiska länderna inom samtliga åldersgrupper (11, 13 och 15 år) när det gäller andelen som borstar tänderna mer än en gång per dag (35-97 \%). Att borsta tänderna mer än en gång per dag är konsekvent vanligare bland flickor än bland pojkar i alla tre åldersgrupperna. Den lägsta siffran för alla åldergrupper gäller finländska pojkar, där mindre än 40 \% borstar tänderna mer än en gång per dag.

Definitioner och avvikelser

Ungdomarna tillfrågades om hur ofta de borstar tänderna. Svarsalternativen sträckte sig från "aldrig” till "mer än en gång per dag”. De resultat, som presenteras här, är de andelar som svarade, att de borstar tänderna mer än en gång per dag.

\subsubsection{Konsumtion av sockerhaltiga läskedrycker}

Indikatorns relevans

Dagligt bruk av sockerhaltiga läskedrycker är en indikator på mindre hälsosamt födointag, särskilt i samband med de allt vanligare problemen med övervikt och fetma. Läskedrycker anses allmänt vara "tomma kalorier”, som förhindrar intag av mer näringsrik mat och gör det svårare för ungdomarna att följa aktuella kostrekommendationer (Guenther PM, 1986; Harnack L, 1999).

Indikatorns vetenskapliga stringens

Konsumtion av läskedrycker och annat socker har kopplats till en förhöjd risk för dålig tandhälsa hos ungdomar, särskilt karies och tanderosion, och förhållandet är kumulativt (Sheiman A, 2001; Touger-Decker R och van Loveren C, 2003; Tahmassebi JF et al., 2006).

\section{Slutsatser}

Det finns en allmän tendens (mer bland pojkar) att konsumtionen av läskedrycker ökar mellan 11- och 15-års åldern. Konsumtionen av läskedrycker 
är högre bland pojkar än flickor, särskilt bland 15-åringar. För 15-åriga flickor varierade konsumtionen från 4 \% (Finland) till 14 \% (Färöarna och Norge) och för 15-åriga pojkar från 9 \% (Finland) till 35 \% (Färöarna).

Definitioner och avvikelser

Ungdomar (11, 13 och 15 år) tillfrågades om hur ofta de konsumerade läskedrycker. Läskedrycker definierades som "Coca Cola eller andra läskedrycker som innehåller socker”. Svarsalternativen sträckte sig från "aldrig” till "mer än en gång om dagen”. De resultat som presenteras här är den andel som svarade, att de dricker läskedrycker varje dag eller oftare.

\subsubsection{Resultatindikatorer}

Andel kariesfria av undersökta barn och ungdomar

Indikatorns relevans

Kunskap om karies hos barn och ungdomar beskriver väl tandhälsan i befolkningen och är ett viktigt underlag för planering och för jämförelser av tandhälsans utveckling regionalt, nationellt och internationellt. Indikatorn används ofta för att bedöma den övergripande nivån av tandhälsan och för att följa trender i tandhälsan över tiden bland grupper av barn och ungdomar.

Indikatorns vetenskapliga stringens

Indikatorn har ofta använts för att mäta den andel av en befolkning, som har värdet 0 för dentinkaries utvärderat enligt DMFT-indexet (Decayed, Missing and Filled Teeth) på $\mathrm{D}_{3}$-nivån (endast dentinkaries), enligt rekommendationerna i WHO:s grundmetoder (WHO, 1997).

\section{Slutsatser}

Under de senaste fyra decennierna har det skett en allmän förbättring av tandhälsan i Norden - andelen kariesfria barn har ökat i alla de nordiska länderna. Vid en jämförelse mellan länderna föreligger dock stora skillnader, t.ex. andelen kariesfria 12-åringar varierar från 34 \% på Island (år 2005) till 69 \% i Danmark (år 2009) (Figur 4).

Definitioner och avvikelser

Indikatorn definieras som andelen undersökta barn och ungdomar i de valda åldersgrupperna utan uppenbar karieserfarenhet. 
- Ingen uppenbar tidigare karieserfarenhet: $\left(\mathrm{D}_{3} \mathrm{MFT}=0 / \mathrm{d}_{3} \mathrm{mft}=0\right)$.

- Ingen uppenbar karies. Dentinkaries $=0 / \mathrm{d}=0$.

- Emaljkariesskador ingår inte.

Det finns behov av att följa de specifika kriterierna och konventionerna för karies i WHO:s grundmetoder (och i förekommande fall i ICDAS avancerade metoder). Detta eftersom de praktiska erfarenheterna av nationella studier har visat, att relativt små förändringar i kriterierna kan ha en väsentlig inverkan på de uppmätta värdena för denna indikator, särskilt när man exakt definierar, när dentinkaries ska anses föreligga. Skillnader mellan länderna kan också bero på varierande användning av röntgenbilder. Vidare registrerar t.ex. inte Sverige saknade tänder $(\mathrm{m} / \mathrm{M})$.

De nordiska länderna samlar in dessa data för delvis olika åldersgrupper. Tre nordiska länder (Danmark, Norge, Sverige) kan presentera färska data från 2008 eller 2009, medan de finländska siffrorna är från 2003. Informationen från Island kommer från en nationell undersökning om tandhälsa. Denna undersökning genomfördes 2005 under vetenskapligt kontrollerade former enligt ICDAS-kriterierna.

Figur 4. Andel kariesfria 12-åringar, \%

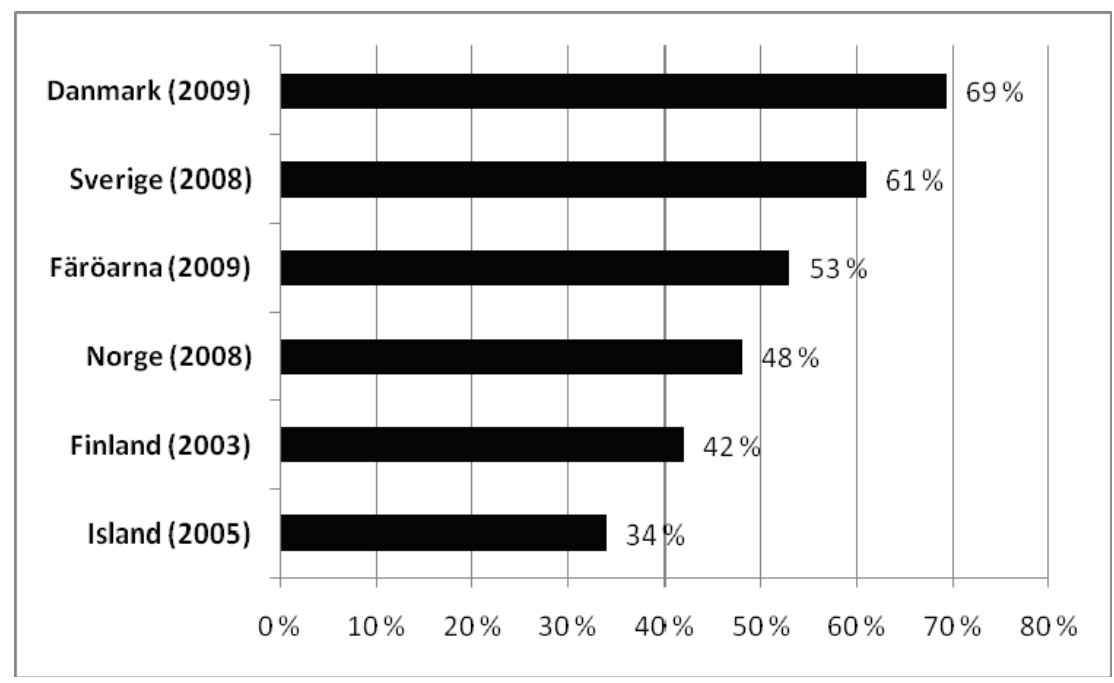

Källa: www.thl.fi/fi_Fl/web/fi/tutkimus/julkaisut/verkkojulkaisut 


\subsubsection{Medelvärdet för $d_{3} m f t / D_{3} M F T$ hos undersökta barn och ungdomar} Indikatorns relevans

För karies används ofta olika typer av index för att beskriva sjukdomens utbredning och svårighetsgrad. Barn- och ungdomstandvården karaktäriseras av ett starkt inslag av förebyggande tandvård. Idag läggs stor vikt vid evidensbaserad tandvård, och fokus har i ökande grad flyttats från reparativa ingrepp (fyllningar) till att tillhandahålla och utvärdera preventiva program och tjänster. Detta kräver indikatorer, som kan användas för att beskriva förekomst och utbredning av karies samt behovet av preventiva åtgärder. Indikatorn kan också visa resultatet av preventiva och sjukdomsbehandlande åtgärder.

Den kan antingen användas för permanenta tänder eller mjölktänder, som summerat mått eller rapporteras separat efter de individuella komponenterna.

Indikatorns vetenskapliga stringens

DMFT-indexet rekommenderas av WHO (WHO, 1997). Med hjälp av DMFT-indexet har tandhälsodata från kliniska undersökningar samlats in tillförlitligt och reproducerbart under många år. I Europa har data också samlats in om karies i ett tidigt skede av sjukdomsprocessen med hjälp av ICDAS-metoden (emalj- och dentinkaries - D 1-nivån) (Pitts NB, 2004).

\section{Slutsatser}

Minskningen av medelvärdena för $\mathrm{D}_{3} \mathrm{MFT}$ i de nordiska länderna under de senaste decennierna framgår av figur 5 . Det genomsnittliga nationella $\mathrm{D}_{3} \mathrm{MFT}$-värdet för 12-åringar är lågt i alla nordiska länder. Det finns dock betydande skillnader mellan de nordiska länderna. Danmark (år 2009) hade lägst $\mathrm{D}_{3} \mathrm{MFT}(0,6)$ och Island (år 2005) högst (2,1). WHO har satt målet för Europa att medelvärdet för DMFT hos 12-åringar inte ska överstiga 1,5 år 2020 (WHO, 1999).

Definitioner och avvikelser

Indexet beskriver det genomsnittliga antalet kariesangripna, saknade och lagade mjölktänder $\left(\mathrm{d}_{3} \mathrm{mft}\right)$ eller permanenta tänder $\left(\mathrm{D}_{3} \mathrm{MFT}\right)$ per person i respektive åldersgrupp bland barn och ungdomar.

Kariesangrepp på nivån endast dentinkaries rapporteras med indexsymbolen d3/D3 för att skilja dem åt från angrepp som även inbegriper tidigare stadier av sjukdomsprocessen (emaljkaries).

De nordiska länderna rapporterar data för olika åldersgrupper. För 12åringar (WHO-indexåldersgruppen) finns det dock data för alla de nordiska 
länderna. Finland, Danmark och Norge samlar in dessa data från patientregister. Island samlar in informationen via enkäter. Sverige registrerar inte saknade tänder (M) med hänvisning till, att denna anses vara statistiskt försumbar.

I den senaste nationella undersökningen på Island 2005 var det nationella medelvärdet för D3MFT för 12-åringar 1,4 på basis av visuell granskning, men medelvärdet för D3MFT steg till 2,1 när även röntgenbildsdata användes.

Figur 5. Förändringar i medelvärdet för $\mathrm{D}_{3} \mathrm{MFT}$-värden för 12-åringar

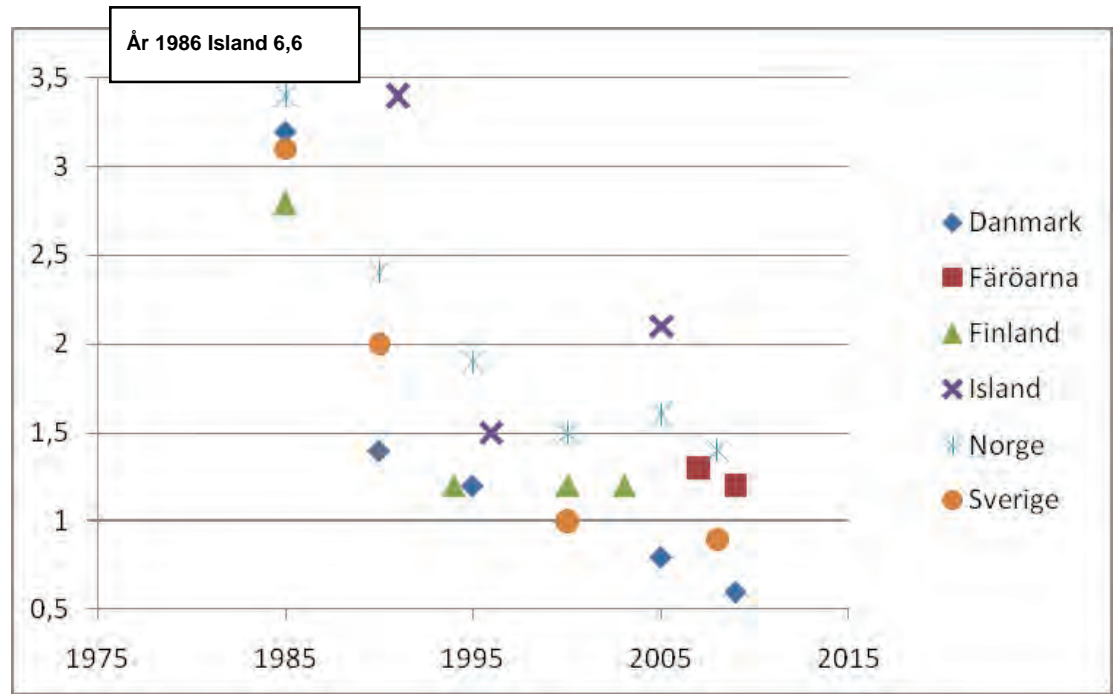

Källa: www.thl.fi/fi_Fl/web/fi/tutkimus/julkaisut/verkkojulkaisut

\subsubsection{Significant Caries Index för 12-åringar}

Indikatorns relevans

En mer ingående analys av kariessituationen i många länder visar, att kariesförekomsten är snedfördelad - en grupp 12-åringar har fortfarande höga eller mycket höga DMFT -värden medan andra grupper är helt kariesfria.

Eftersom medelvärdet för DMFT inte avspeglar denna snedfördelning, finns det risk för den felaktiga slutsatsen, att kariessituationen är under kontroll för hela befolkningen, trots att många i själva verket fortfarande har karies (Bratthall D, 2000). Significant Caries Index (SiC) infördes för att fästa uppmärksamhet på de individer som har de högsta kariesvärdena i respektive undersökt befolkning (www.whocollab.od.mah.se). SiC utgör medelvärdet för DMFT för den tredjedel av befolkningen som har flest antal kariesskador. 
Att med SiC rikta uppmärksamheten mot de barn som har flest kariesskador leder till betydande vinster för samhället och för de berörda personerna, då mer specifikt riktade preventiva åtgärder kan genomföras. Barn med hög kariesförekomst behöver sannolikt komplicerade och dyra behandlingar i framtiden. WHO:s mål är, att SiC för 12-åringar år 2015 ska vara lägre än 3.

Indikatorns vetenskapliga stringens

$\mathrm{SiC}$ är en indikator som avspeglar situationen bland de mest kariesdrabbade individerna och kan tas med i befolkningsbaserade tandhälso-undersökningar tillsammans med medelvärdet för DMFT (Nishi M, 2002).

Slutsatser

SiC för 12-åringar på Island är 4,7 (år 2005), Danmark 1,9 (år 2009), Norge 3,5 (år 2009) och Sverige 2,5 (år 2008).

Definitioner och avvikelser

$\mathrm{SiC}$ är medelvärdet för DMFT för den tredjedel av befolkningen som har flest kariesskador. Sverige registrerar inte saknade tänder (M). Island presenterar data från en nationell undersökning om tandhälsa från 2005.

\subsubsection{Andel (\%) tandlösa 65-74-åringar i befolkningen}

Indikatorns relevans

En allt bättre munhygien, tillgång till vårdtjänster, teknisk utveckling inom tandvården samt socioekonomiska faktorer har lett till, att allt fler människor har kvar allt fler av sina naturliga tänder, allt senare i livet. Förlusten av alla naturliga tänder kan bidra till psykologiska, sociala och fysiska svårigheter. Andelen tandlösa är ett mått på genomgången sjukdom och en indikator för oral hälsa.

Indikatorns vetenskapliga stringens

Tandlöshetsindex rekommenderas av WHO (WHO, 1997), och att minska antalet tandlösa är ett av WHO:s globala mål för tandhälsa som ska ha uppnåtts år 2020. 
Slutsatser

Andelen tandlösa (65-74-åringar) varierade från 7 \% i Norge (år 2008) till 36 \% i Finland (år 2000). Tandlösheten minskar snabbt i alla de nordiska länderna.

Definitioner och avvikelser

Andelen 65-74-åringar som har förlorat alla sina naturliga tänder.

Tandlöshet: Avsaknad av samtliga naturliga tänder.

Naturliga tänder: Avser tänder som bildats i munnen och exkluderar konstgjorda tänder, implantat och tandproteser. Alla nordiska länder kan inte rapportera dessa data. Finländska data kommer från en nationell hälsoundersökning. Danmark, Island och Norge samlar in självrapporterade data om tandlöshet genom intervjuundersökningar. Data från Sverige kommer att hämtas från det nationella tandhälsoregistret.

Andel (\%) 65-74-åringar som har minst 20 kvarvarande tänder i munnen

Indikatorns relevans

Tandsjukdomar påverkar människans mest grundläggande funktioner som förmågan att äta och dricka, svälja, le och kommunicera. Tandsjukdomar påverkar inte bara hälsan i munhålan utan kan orsaka problem för allmänhälsan och minska välbefinnandet. Människor som saknar tänder, måste ibland välja mat, som inte är optimalt näringsriktig. Hos äldre kan dålig tandhälsa leda till betydande viktförlust som kan påverka allmänhälsan.

Tidig tandförlust har visat sig vara en prediktor för tandlöshet. Parallellt med att man fortsätter att satsa på att förhindra tandförlust, finns det behov av att utvärdera lämpliga ersättningar för förlorade tänder. Den här indikatorn ger tillsammans med indikatorn om tandlöshet ett bredare perspektiv om tandhälsan i befolkningen. Den kan också användas för att bedöma vilken inverkan olika bakgrundsfaktorer och behandlingsinsatser har för tandhälsan.

Indikatorns vetenskapliga stringens

Många befolkningsbaserade studier av tandhälsa har angett ett minimum på 20 tänder, eller ibland ett visst antal bakre tänder som kommer i kontakt med varandra, som ett enkelt sätt att definiera "tillfredställande” mun- och tandhälsa (WHO, 1997). 
Slutsatser

Andelen vuxna i åldern 65-74 år med 20 eller fler naturliga tänder är högst i Norge med 66 \% (år 2008) och lägst på Island med 33 \% (år 2007).

Definitioner och avvikelser

Andel vuxna i åldern 65-74 med 20 eller fler naturliga tänder.

Permanenta tänder avser (normalt) 32 tänder i en permanent tanduppsättning. De 32 tänderna finns i vardera käken, i över- och underkäken.

Funktionell ocklusion: Förekomst av 20 eller fler naturliga tänder har använts internationellt som definition på en fungerande tanduppsättning, dvs. en som gör det möjligt att utan någon form av tandprotes äta, tala och umgås utan besvär eller obehag.

Tandförsedd: Förekomst av en eller flera naturliga tänder. Alla nordiska länder kan inte rapportera dessa data. Norge och Danmark samlar in självrapporterade data genom intervjuundersökningar. Uppgifterna från Island gäller åldersgruppen 65-79 från en enkätundersökning 2007. Data från Sverige kommer att hämtas från det nationella tandhälsoregistret.

Potentiella indikatorer

Andel av befolkningen som besöker tandvården regelbundet (inom en period av 2/3 år)

Indikatorns relevans

Den här indikatorn tjänar flera syften och kompletterar indikatorn ”Andel (\%) av befolkningen som har besökt tandvården inom ett år”. Under de senaste decennierna har det skett en allmän förbättring av tandhälsan i Norden.

Regelbundna tandvårdsbesök gör det möjligt att upptäcka och åtgärda tecken på sjukdomar i munhålan på ett tidigt stadium, vilket minskar de framtida behoven av tandvård. Indikatorn visar i vilken utsträckning befolkningen besöker tandvården regelbundet.

Slutsatser

Data för den här indikatorn finns bara tillgängliga från ett fåtal länder, men indikatorn ansågs så viktig att arbetsgruppen föreslår den som en potentiell indikator. De nordiska länderna planerar att ta fram jämförbara data inom 2-3 år. 
Definitioner och avvikelser

Andel av befolkningen som besökt distriktstandläkare/folktandvårdsklinik eller privattandläkare/privattandvårdsklinik under de 2 senaste åren. Alternativt kan en period av 3 år användas för att mäta så kallade "drop outs”. Tandvårdsbesöken kan presenteras separat efter orsak som regelbundna kontroller eller besök som beror på tandbesvär.

\section{Självupplevd tandhälsa (munhälsa)}

Indikatorns relevans

Många länder genomför regelbundet intervjuundersökningar där de svarande får beskriva olika aspekter av sin hälsa. En fråga som ofta ställs har att göra med självupplevd tandhälsa, t.ex.: ”Hur är din tandhälsa allmänt sett?”

\section{Slutsatser}

Data för den här indikatorn finns bara tillgängliga från ett fåtal länder, men indikatorn ansågs så viktig, att arbetsgruppen föreslår den som en potentiell indikator. De nordiska länderna planerar att ta fram jämförbara data inom 2-3 år.

Definitioner och avvikelser

Självupplevt hälsotillstånd avspeglar folks allmänna uppfattning om sin hälsa och kan beröra alla fysiska och psykologiska dimensioner. De som svarar på enkäten får vanligen frågor av typen: "Hur är din tandhälsa allmänt sett? Mycket god, god, ganska god, dålig, mycket dålig”.

Den här indikatorn definieras som den andel av den vuxna befolkningen, som bedömer sin tandhälsa som antingen "god" eller "mycket god".

Det behövs viss försiktighet vid tvärnationella jämförelser av självupplevt hälsotillstånd. Hälsobedömningarna är subjektiva och kan påverkas av faktorer som kulturell bakgrund och nationella särdrag.

Självupplevd tuggförmåga

Indikatorns relevans

Fysisk och social funktionsförmåga är en av dimensionerna i tandhälsorelaterad livskvalitet. Uppföljning av orala handikapp som beror på funktionella begränsningar har konsekvenser vid bedömning av den långsiktiga ef- 
fektiviteten i tandvården. Förekomst av orala handikapp är betydande. Uppfattningen är att tandhälsa har en väsentlig inverkan på livskvaliteten.

Slutsatser

Data för den här indikatorn finns bara tillgängliga från ett fåtal länder, men indikatorn ansågs så viktig att arbetsgruppen föreslår den som en potentiell indikator. De nordiska länderna planerar att ta fram jämförbara data inom 2-3 år.

Definitioner och avvikelser

Andelen vuxna patienter som har upplevt problem med att äta och tugga på grund av mun-, tand- eller tandprotesproblem av varierande svårighetsgrad under de senaste 12 månaderna. För att samla in dessa data skall varje person $\mathrm{i}$ studien få frågan "Kan du tugga hårda eller sega födoämnen? Utan svårighet, med svårighet eller inte alls."

Indikatorn definieras som den andel som svarar "med svårighet” eller "inte alls”. Indikatorn visar andelen vuxna som har dålig eller mycket dålig tuggförmåga.

Diskussion och framtidsperspektiv

Detta projekt är det första gemensamma projektet för utveckling av kvalitetsindikatorer för mun- och tandhälsovården i de nordiska länderna och som har finansierats av Nordiska ministerrådet.

Arbetsgruppen har enats om 12 indikatorer för vilka data finns tillgängliga i minst tre nordiska länder. Arbetsgruppen har även föreslagit tre potentiella indikatorer. Mycket arbete har lagts ned på att definiera indikatorerna och säkerställa kvalitet på insamlade data.

Grundläggande registerdata kan användas för jämförelser av de deltagande länderna, men det krävs ytterligare arbete för att utveckla indikatorer, som är mer exakt kopplade till kvalitet. Arbetsgruppen betonar vikten av, att alla nordiska länder arbetar för att regelbundet ta fram data om de överenskomna indikatorerna utifrån samma metoder, t.ex. identiska definitioner och jämförbara åldersgrupper.

Arbetsgruppen föreslår att datainsamlingen genomförs på nytt med de aktuella indikatorerna samt eventuella nya kvalitetsindikatorer, och att datainsamlingarna därefter genomförs med 3-5 års intervall.

OECD-rapporterna tar bara upp grundläggande data om tandhälsa, och arbetsgruppen ser det därför som önskvärt att koppla ihop detta arbete med 
OECD:s projekt för hälsovårdens kvalitetsindikatorer (Health Care Quality Indicators).

I framtiden behövs fler kvalitetsindikatorer för tandhälsa, och arbetsgruppen föreslår att arbetet fortsätter. Viktiga områden där ytterligare indikatorer bör utvecklas är t.ex. vårdtillgänglighet, patienttillfredsställelse, parodontala sjukdomar och deras behandling, implantatvård, omfattningen av ortodontiska behandlingar, resultatet av rotbehandlingar och förekomsten av erosion.

En mer omfattande rapport på engelska finns på www.thl.fi/fi_FI/web/fi/tutkimus/julkaisut/verkkojulkaisut.

\section{Referencer}

Bratthall D.(2000) Introducing the Significant Caries Index together with a proposal for a new oral health goal for 12-year-olds. Int Dent J. 50: 378-384. Guenther PM (1986). Beverages in the diets of American teenagers. Journal of the American Dietetic Association;86:493-499.

Harnack L, Stang J, Story M (1999). Soft drink consumption among US children and adolescents: nutritional consequences. Journal of the American Dietetic Association;86:99436.

Health at a Glance (2009): OECD Indicators Health Surveillance in Europe (2005). A selection of essential oral health indicators. Projektet stöds av Europeiska kommissionens generaldirektorat för hälsa och konsumentskydd. www.egohid.eu.

Löe H (2000). Oral hygiene in the prevention of caries and periodontal disease. International Dentistry Journal; 50:129-39.

Macgregor IDM, Regis D, Balding JW (1997). Self-concept and dental health behaviors in adolescents. Journal of Clinical Periodontology; 24:335-339.

Mainz J (2003). Defining and classifying clinical indicators for quality improvement. International Journal for
Quality in Health Care; 15(6): 523530.

Maes L et al. (2006) Tooth brushing and social characteristics of families in 32 countries. International Dental Journal; 56:159-67.

McGrath C, Bedi R (2000). Gender variation in the social impact of oral health. Journal of the Irish Dental Association; 46:87-91Nishi $\mathrm{M}$ et al. (2002) Caries experience of some countries and areas expressed by the Significant Caries Index. Community Dent Oral Epidemiol 30:296-301.

Pitts NB (2004). “ICDAS”- an international system for caries detection and assessment being developed to facilitate caries epidemiology, research and appropriate clinical management. Community Dental Health 21:193198.

Sheiham A (2001). Dietary effects on dental diseases. Public Health Nutrition; 4:569-591.

Tahmassebi JF et al.(2006) Soft drinks and dental health: a review of the current literature. Journal of Dentistry; 34(1):2-11.

Touger-Decker R, van Loveren C (2003). Sugars and dental caries. 
American Journal of Clinical Nutrition; 78:881S-892S.

WHO (2003). The World Oral Health Report 2003. Continuous improvement of oral health in the 21st century - the approach of the WHO Global Oral Health Programme. Genève: WHO.

WHO (2000). "What resources are needed?” i World Health Report 2000. Health Systems: Improving Performance, kapitel 4, sidorna 73-92.

Genève: WHO.
WHO (1999) Health21: the health for all policy framework for the WHO European Region. European Health for All Series No. 6. ISBN 9289013494 WHO:s regionkontor för Europa (1998). Terminology - A glossary of technical terms on the economics and finance of health services. Köpenhamn: WHO:s region-kontor för Europa.

WHO (1997). Oral health surveys, Basic Methods (4thed.) Genève: WHO 



\section{4. kapitel}

\subsection{Kvalitetsindikatorer för patientsäkerhet}

\subsubsection{Syfte}

Patientsäkerhet betraktas allmänt som det viktigaste kvalitetsområdet i hälsooch sjukvården. Bristande patientsäkerhet orsakar vårdskador, vilket medför ett stort mänskligt lidande och betydande kostnader för samhället $(1,2)$. Hög patientsäkerhet är en förutsättning för att upprätthålla medborgarnas förtroende för hälso- och sjukvården. Det är därför angeläget att utveckla indikatorer, som belyser graden av patientsäkerhet i vården. Ett sådant arbete pågår redan inom OECD och EU, och det nordiska samarbetet kan ge värdefulla bidrag.

\subsubsection{Introduktion}

Patientsäkerhet är ett tämligen nytt begrepp och arbetsfält, där forskningen och kunskapsuppbyggnaden nyligen har startat. Följaktligen saknar många segment av patientsäkerhetsområdet fungerande strukturer och register för datainsamling, samt den kunskap och vetenskapliga dokumentation (3) som behövs för att ta fram väl underbyggda indikatorer.

Nordiska ministerrådets tidigare projekt om patientsäkerhetsindikatorer (år 2006) utvärderade möjligheten att använda några av de indikatorer, som hade föreslagits av OECD. Dessa indikatorer bygger på den diagnos- och komplikationsregistrering enligt klassifikationssystemet ICD-10, som sedan många år rapporteras in till de nordiska ländernas patientregister.

Resultatet av arbetet visade, att ingen av de prövade OECD-indikatorerna gick att använda, förutom indikatorerna inom förlossningsområdet. Anledningen var dels, att sjukvården bara rapporterar in en liten del av de ICD-10- 
koder som rör patientsäkerhet, dels att de nordiska länderna inte registrerar patienternas intagningsdiagnos.

\subsubsection{Motivering till val av prioriterade indikatorer och potentiella indikatorer}

Utgångspunkten för den nordiska projektgruppens arbete blev att fortsätta samarbetet med OECD, men också att söka efter andra typer av patientsäkerhetsindikatorer än de som baseras på ICD-10-data.

Projektgruppen har undersökt möjligheten att ta fram patientsäkerhetsindikatorer på områdena

- vårdskador i sluten somatisk vård

- patientsäkerhetskultur

- sjukhusmortalitet

- vårdrelaterade infektioner

- överförskrivning av läkemedel hos äldre.

Området vårdskador inom somatisk vård valdes, därför att det finns beprövade metoder för att mäta förekomsten och typen av vårdskador, som uppstår i olika slags verksamheter (4-6). För att patientsäkerhetsarbetet ska fungera, måste sjukvården arbeta systematiskt med metoder för att kartlägga brister, och för att mäta effekterna av olika förbättringsåtgärder.

Området patientsäkerhetskultur valdes, därför att det inom andra högriskverksamheter som exempelvis flyget, finns starka belägg för att ledningens och medarbetarnas attityder och förhållningssätt till säkerhet (säkerhetskulturen) har ett starkt samband med säkerheten i verksamheterna. Under arbetets gång har studier publicerats som pekar på ett motsvarande samband inom hälso- och sjukvården (8-7).

Området sjukhusmortalitet valdes, eftersom det fanns tecken på, att metoden Hospital Standardized Mortality Ratios kunde ligga till grund för en indikator med acceptabel validitet och relevans (9). Projektgruppen kom dock fram till, att metoden inte är användbar för jämförelser mellan de nordiska länderna (10). Arbetet inriktades därefter på att utveckla en annan indikator för att belysa sjukhusmortalitet, Death in low-mortality DRGs (11) som dock heller inte visade sig vara användbar. 
Området vårdrelaterade infektioner valdes, därför att sådana infektioner är vanliga, och att de orsakar betydande kostnader och lidande och oftast går att undvika $(12,13,14)$.

Flera indikatorer på detta område har tagits fram av European Centre for Disease Prevention and Control (ECDC). Utgångspunkten för arbetet har varit att välja ut de ECDC-indikatorer, som i första hand är lämpliga att använda i Norden.

Området överförskrivning av läkemedel hos äldre valdes, därför att s.k. polyfarmaci hos äldre är vanlig och kan leda till en rad olika oönskade konsekvenser $(15,16)$. Dessutom kan tillförlitliga data hämtas ur befintliga register.

\subsubsection{Resultat av datainsamling}

För de flesta av indikatorerna saknas fungerande kanaler för att samla in och sammanställa data på nationell nivå. För de föreslagna indikatorerna redovisas spridningen av indikatorn i varje land tillsammans med förslag på hur indikatorn ska användas, vilken organisation som kan samla in och sammanställa data, samt när indikatorn kan väntas vara i bruk. I många fall behövs också mer arbete för att närmare definiera indikatorn och dess nämnare. Arbetet har kommit längst, när det gäller indikatorer på överförskrivning av läkemedel.

\subsubsection{Diskussion}

För varje indikatorområde har projektgruppen inrättat en expertgrupp med representanter från de olika länderna, och arbetet i varje grupp har letts av en medlem i projektgruppen. Expertgrupperna har varit ett viktigt forum för ömsesidigt lärande och kunskapsutbyte mellan länderna, när det gäller patientsäkerhetsarbete.

Grupperna har också bidragit till att förankra indikatorerna i sina respektive länder, och det nordiska samarbetet kring patientsäkerhets-indikatorer har påskyndat patientsäkerhetsarbetet i de enskilda nordiska länderna. En utgångspunkt för arbetet har varit, att de indikatorer som tas fram i projektet, även ska vara användbara för jämförelser inom länderna.

I en del nordiska länder har arbetet i Nordiska ministerrådets projektgrupp pågått parallellt med nationella projekt för att ta fram patientsäkerhetsindikatorer. Detta har medfört, att de indikatorer, som presenteras i denna rapport, i viss utsträckning ingår i några av ländernas nationella indikatorset, och för de 
indikatorerna finns i viss mån planer för datainsamling och datasammanställning. Ett antal indikatorer ingår dock inte i några nationella indikatorset, och för dem behöver varje land vidta nationella åtgärder för att kunna samla in och sammanställa data.

Flera av medlemmarna i projektgruppen har också varit sina respektive länders representanter i OECD:s pilotprojekt om patientsäkerhetsindikatorer. De nordiska länderna har snarlika förutsättningar för att kunna använda de ICD-10-baserade patientsäkerhetsindikatorerna som OECD föreslår, och därför har projektgruppen kunnat göra gemensamma ställningstaganden i OECDsamarbetet.

Medlemmarna i projektgruppen och expertgrupperna framgår av bilaga 14

\subsubsection{Fortsättning}

OECD:s förlossningsskadeindikatorer, PSI 18 och 19 (17) har goda förutsättningar att vidareutvecklas i de nordiska länderna, eftersom rapporteringen av data på detta område är av förhållandevis god kvalitet. Finland har särskilt goda utfall i dessa indikatorer, och norska förlossningsavdelningar har därför etablerat kontakt med finländska obstetriker och barnmorskor, för att ta del av deras arbetssätt.

Data hämtas dock både från medicinska födelseregister och från olika patientregister, och det kan också finnas skillnader mellan de nordiska länderna när det gäller bedömningen av en förlossningsskadas allvarlighetsgrad. Hur detta eventuellt kan påverka resultaten behöver klargöras i det fortsatta arbetet.

Två indikatorer räcker dock inte för att ge en rättvisande bild av säkerheten i förlossningsvården, utan de bör kompletteras med fler indikatorer, bland annat kejsarsnittsfrekvens. Det fortsatta arbetet bör inriktas på att ta fram en samling (eng. "bundle”) indikatorer, som belyser kvaliteten i förlossningsvården, och ett sådant arbete har redan påbörjats i Danmark.

Projektgruppen föreslår att det tillsätts en nordisk expertgrupp för obstetrik, bland annat för att harmonisera bedömningskriterierna och datahanteringen. Utvecklingsarbetet kan med fördel drivas i samarbete med OECD.

Även andra av OECD:s föreslagna patientsäkerhetsindikatorer har hög validitet och relevans. Det är därför angeläget att undersöka, om de nordiska ländernas ICD-10-baserade registreringssystem kan utvecklas och förbättras, så att fler av dessa kan användas. I det fortsatta samarbetet med OECD är det 
särskilt viktigt att utveckla mer specifika indikatorer, t.ex. djup ventrombos efter elektiv ortopedisk kirurgi.

Traditionellt har patientsäkerhetsindikatorer baserats på registrering av olika typer av skador och komplikationer, dvs. sådant som antyder, att det kan ha gjorts misstag i vården. Nu börjar dock vården introducera s.k. följsamhetsmätningar, vilket är en lovande utveckling. Följsamhetsmätningar innebär, att man systematiskt mäter i vilken utsträckning personalen följer regler och rutiner som är avgörande för patientsäkerheten, t.ex. följsamheten till basala hygienrutiner (18) eller till WHO:s checklista för kirurgi.

Denna utveckling skapar förutsättningar för att ta fram en ny typ av indikatorer: indikatorer för säker vård.

\subsection{Vårdskador i sluten somatisk vård}

\subsubsection{Strukturerad journalgranskning för att identifiera och mäta förekomst av skador i vården}

\section{Indikatorns betydelse}

Det är viktigt att kunna bedöma, om en verksamhet i hälso- och sjukvården är säker, och om det patientsäkerhetsarbete som bedrivs är framgångsrikt. Som underlag behövs fakta kring antalet patienter som skadas i vården, och hur stor andel av dessa som är undvikbara, dvs vårdskador. Det finns olika metoder för att kartlägga antalet skador, exempelvis obligatorisk och frivillig avvikelserapportering, analys av rapporterade vårdskador till försäkringsbolag samt strukturerad journalgranskning.

Avvikelsehantering är i många länder en av grundstenarna för patientsäkerhetsarbetet. I hälso- och sjukvårdens avvikelserapporteringssystem registreras dock sällan de allvarligaste avvikelserna, som har lett till att patienter skadats $(19,20)$. Därför behövs ett komplement till den traditionella avvikelserapporteringen för att identifiera skador och mäta deras antal.

Strukturerad journalgranskning är en sådan kompletterande metod, som har använts för att kartlägga förekomsten av skador i samband med somatisk sjukhusvård. Resultaten har använts i Institute of Medicines rapport "To Err is Human” som publicerades 1999 (21), och som skapade ett stort intresse kring patientsäkerhetsfrågor, inte bara i USA utan även i flera andra länder. Sedan 
dess har nationella studier med liknande metodik genomförts i flera länder $(1,2,22,23)$, och visat att andelen patienter som skadas i vården ligger runt 10 procent. I flertalet länder som genomfört sådana studier, har resultaten bidragit till nationella initiativ för att förbättra patientsäkerheten.

\section{Vetenskapligt belägg}

Allt fler sjukvårdsorganisationer i världen använder strukturerade journalgranskning, både för att mäta och följa nivån på skador och som en integrerad del i förbättringsarbetet. Det finns några olika metoder som används på lokal eller regional nivå $(4,5,24)$. Gemensamt för samtliga metoder är att man letar i patientjournalen efter uppgifter som kan tyda på, att patienten har skadats, och när sådana påträffas görs en noggrann genomgång av journalen.

Journalgranskning med hjälp av metoden Global Trigger Tool (GTT) används allt mer av olika sjukvårdsorganisationer i USA (25), och i Storbritannien har National Health Service (NHS) genom Institute for Innovation and Improvement rekommenderat användningen av GTT för att följa patientsäkerhetsarbetets utveckling. Metoden finns även med som ett kvalitetsverktyg i Agency for Healthcare Research and Quality's (AHRQ) s.k. "innovations exchange" (www.ahrq.gov).

Att mäta antalet skador leder inte i sig till en förbättrad patientsäkerhet utan metoden måste kombineras med aktiva åtgärder för att minska antalet skador (25). Att identifiera skador med hjälp av journalgranskning kan bidra till ett förbättringsarbete på kliniknivå $(6,26)$. AHRQ har publicerat ett expertpanelsutlåtande, där man beskriver metoder för att identifiera skador via journalgranskningar samt diskuterar frågor kring validitet och prediktionsvärde (27).

\section{Resultat}

Nedan följer projektgruppens bedömning av hur utbredd användningen av strukturerad journalgranskning var i respektive land våren 2010.

Danmark: Under 2009 skickades ett utbildningsmaterial om GTT-metoden till alla sjukhus i landet. Mellan 1 och 25 procent av alla somatiska akutsjukhus använder metoden.

Finland: I Finland har man för åren 2009-2013 formulerat en nationell strategi för patientsäkerhet. Verkställandet av strategin stöds av Institutet för hälsa och välfärd, som i samarbete med övriga aktörer håller på att ta fram en handbok med vägledning för implementering av olika delar av strategin. Bland annat kommer frågor om identifiering, rapportering och handläggning 
av avvikelser att beröras. Metoden strukturerad journalgranskning används ännu inte.

Färöarna: Metoden strukturerad journalgranskning används inte.

Grönland: Metoden strukturerad journalgranskning används inte.

Island: En journalgranskningsstudie kommer att genomföras under år 2010 med liknade metodik som i andra nationella vårdskadestudier. I övrigt använder man inte metoden strukturerad journalgranskning.

Norge: GTT är den vanligaste metoden för strukturerad journalgranskning. Mellan 1 och 25 procent av alla somatiska akutsjukhus använder metoden.

Sverige: GTT är den vanligaste metoden för strukturerad journalgranskning. Över 25 procent men mindre än 50 procent av alla somatiska akutsjukhus använder metoden.

En mer detaljerad beskrivning av metodens utbredning kan fås av projektgruppens ordförande Michael Soop (michael.soop@socialstyrelsen.se). Hur indikatorn kan införas i de nordiska länderna framgår av tabell 1 nedan.

Tabell 1. Hur indikatorn kan införas i de nordiska länderna

\begin{tabular}{|c|c|c|c|}
\hline \multirow[t]{2}{*}{ Land } & \multicolumn{3}{|c|}{ Indikatorns namn: Strukturerad journalgranskning Indikator $1 \mathrm{a}, \mathbf{1 b}, \mathbf{1 c}$} \\
\hline & $\begin{array}{l}\text { Plan för hur indikatorn ska } \\
\text { användas }\end{array}$ & $\begin{array}{l}\text { Organisation som kan samman- } \\
\text { ställa data }\end{array}$ & $\begin{array}{l}\text { När indikatorn } \\
\text { beräknas vara i } \\
\text { bruk }\end{array}$ \\
\hline Danmark & $\begin{array}{l}\text { Anvendes nationalt som } \\
\text { patientsikkerhedsindikator } \\
\text { på sygehusniveau (struktur) } \\
\text { sammen med HSMR- } \\
\text { publicering }\end{array}$ & $\begin{array}{l}\text { Danske Regio- } \\
\text { ner/Sundhedsstyrelsens } \\
\text { projektorganisation vedrøren- } \\
\text { de HSMR }\end{array}$ & 2011 \\
\hline Finland & $\begin{array}{l}\text { GTT metoden håller på att } \\
\text { utvärderas }\end{array}$ & & \\
\hline \multicolumn{4}{|l|}{ Färöarna } \\
\hline \multicolumn{4}{|l|}{ Grönland } \\
\hline \multicolumn{4}{|l|}{ Island } \\
\hline Norge & Nasjonal indikator & $\begin{array}{l}\text { Enhet for pasientsikkerhet, } \\
\text { Kunnskapssenteret }\end{array}$ & 2011 \\
\hline Sverige & $\begin{array}{l}\text { Nationell indikator för God } \\
\text { vård. Öppna jämförelser }\end{array}$ & $\begin{array}{l}\text { Sveriges Kommuner och } \\
\text { Landsting/Socialstyrelsen }\end{array}$ & 2011 \\
\hline
\end{tabular}




\section{Definition och överväganden}

Syftet med indikatorn är att mäta spridningen av metoden strukturerad journalgranskning som en del av patientsäkerhetsarbetet i respektive lands somatiska sjukhusvård. Indikatorn ska användas både för att mäta och följa nivån på skador, men även som en integrerad del i förbättringsarbetet. Därför är indikatorn indelad i tre undergrupper för att spegla användningen på sjukhusoch kliniknivå.

Täljare

1a. Antal somatiska akutsjukhus i landet som använder strukturerad journalgranskning i patientsäkerhetsarbetet.

1b. Antal somatiska akutsjukhus som varje månad använder strukturerad journalgranskning i patientsäkerhetsarbetet och som publicerar antalet skador/1 000 vårddagar eller antalet skador/100 vårdtillfällen.

1c. Antal somatiska akutsjukhus där strukturerad journalgranskning används som del av det kliniska förbättringsarbetet på kliniknivå.

\section{Nämnare}

Projektgruppen har funnit att det saknas en definition av begreppet "somatiskt akutsjukhus". I flera nordiska länder kan man dock använda de befintliga sätten att redovisa indikatorer för somatisk akutsjukhusvård. I Sverige kan man exempelvis använda samma redovisningssätt som i Öppna jämförelser.

(www.socialstyrelsen.se/uppfoljning/oppnajamforelser/halso-ochsjukvard), och i Danmark kan nämnarproblematiken lösas inom ramen för den danska ackrediteringen.

För att överbrygga svårigheten med definitionen av somatiskt akutsjukhus föreslår projektgruppen, att varje nordiskt land på sitt eget sätt mäter användningsgraden av strukturerad journalgranskning inom den somatiska akutsjukhusvården och redovisar resultatet enligt nedan:

- Metoden används inte

- 1-25 procent av alla somatiska akutsjukhus använder metoden

- Över 25 och mindre än 50 procent av alla somatiska akutsjukhus använder metoden

- Över 50 och mindre än 75 procent av alla somatiska akutsjukhus använder metoden

- Över 75 procent av alla somatiska akutsjukhus använder metoden. 


\subsection{Patientsäkerhetskultur}

\subsubsection{Måling af patientsikkerhedskultur (klima)}

Patientsikkerhedskultur er den del af organisationens kultur, som har særlig betydning for patientsikkerhed - det vil sige produktet af individuelle og gruppeværdier, holdninger, opfattelser, kompetencer og adfærdsmønstre, der bestemmer organisationens engagement og kompetence i forhold til patientsikkerhed. En positiv patientsikkerhedskultur er karakteriseret ved kommunikation mellem medarbejdere, medarbejdereledelse, præget af gensidig tillid, af fælles opfattelser af vigtigheden af sikkerhed og tillid til institutionens indsats i forhold til sikkerhedsfremme og forebyggelse $(28,29)$.

Arbejdet med sikkerhedskultur i sundhedsvæsenets organisationer anses for at være et af de væsentlige indsatsområder i patientsikkerhedsarbejdet. Patientsikkerhedskultur kan ikke måles direkte, men højrisiko industrier har udviklet spørgeskemabaserede metoder, der undersøger medarbejdere og lederes opfattelse og holdninger til sikkerhed i organisationen. Disse metoder har vist sig anvendelige som grundlag for sikkerhedsarbejde i organisationer, som for eksempel olieboreindustrien $(28,30)$.

I forhold til sundhedsvæsenet har man overført disse patientsikkerhedsklimaundersøgelser. Undersøgelser er internationalt - udenfor de nordiske lande - særdeles udbredte. Der eksisterer nu gennemprøvede, validerede instrumenter, der har fundet anvendelse i forbindelse med:

- Bevidstgørelse af sundhedsvæsenets ledere og medarbejdere om patientsikkerhedsproblemer

- Diagnosticering af aktuel patientsikkerhedskultur i organisationen med identificering af styrker og forbedringsområder

- Undersøgelse af udvikling af patientsikkerhedskultur over tid

- Undersøgelse af effekt af initiativer og interventioner i forhold til patientsikkerhed.

Patientsikkerhedskultur (klima) målinger må derfor betragtes som et vigtigt redskab i forbedringsarbejdet $(30,31)$.

Der eksisterer talrige validerede redskaber til måling af patientsikkerhed, de hyppigst anvendte er udviklet i USA: AHRQ (Agency for Healthcare, Research and Quality) og SAQ (Safety Attitudes Questionnaire). Begge værktø- 
jer findes i versioner, der efterhånden dækker sundhedsvæsenet bredt, det vil sige både hospitalsvæsen og primær sektor.

\section{Videnskabeligt belceg}

Ud over en række tekniske forudsætninger (psykometrisk validering, bredde i redskabernes dimensioner) er der tre forudsætninger, som bør være opfyldt. For det første skal målingerne afspejle interventioner, som vides at påvirke patientsikkerhedsniveauet i organisationerne.

For det andet bør patientsikkerhedskulturmålingerne kunne relateres til organisatoriske forhold med kendt effekt på patientsikkerhed. Og for det tredje - væsentligst - bør patientsikkerhedskultur være associeret til andre mål for patientsikkerhed (behandlingskomplikationer, mortalitet, observerbar sikker medicineringsadfærd).

Med hensyn til effekt af interventioner påvirkes patientsikkerhedskultur både af patientsikkerhedsrunder, teamtræning, formaliserede brede programmer, rettet mod forbedring af patientsikkerhed, smallere programmer rettet mod f.eks. medicineringssikkerhed (7,32-37).

Hvad angår samvariation mellem patientsikkerhedskultur og organisatoriske forhold er der belæg for at patientsikkerhedskultur påvirkes af sygeplejenormering, sygeplejerskers arbejdsforhold, organisationskultur målt med ikkepatientsikkerhedsrelaterede instrumenter (38-40).

En lang række arbejder dokumenterer endvidere samvariation i tværsnitsstudier samt parallel udvikling i tidsstudier mellem målt patientsikkerhedskultur og andre mål for patientsikkerhedsniveau (41-57).

Særlig markant ses dette i Keystone projektet i Michigan, hvor der ses højsignifikantrelationer, både mellem kulturniveau og kulturforbedring og central venekateterinfektion og respiratorpneumoni (53-31). Evidensen er imidlertid ikke entydig jævnfør $(59,60)$. Der mangler stadig demonstration af, at målt patientsikkerhedskultur direkte påvirker relevante resultatparametre. Flertallet af arbejderne hviler på tværsnitsstudier eller simple før-efter målinger uden kontrolgruppe og demonstrerer derfor kun samvariation.

Samtidig foreligger efterhånden solid erfaring, som danner grundlag for bedste praksis i forhold til både patientsikkerhedskulturmålinger og resultatmålinger i forhold til patientsikkerhed (30,61-70). Kun en del af arbejderne opfylder disse $(7,32,33,43,49,50,53-57)$. 
Selv om evidensen for anvendeligheden ikke kan betragtes perfekt, og der stadig er behov for forskningsindsats, må det konkluderes at baggrunden for patientsikkerhedskulturmålingers anvendelighed er veldokumenteret

- når de anvendes på klinisk team/afsnits niveau

- når de anvendes til intern sammenligning (f.eks effektmåling af interventioner)

- når de anvendes som udgangspunkt for identifikation af problemområder ved intern fortolkningsproces

- når tilslutningsgrad fra deltagende medarbejdere er repræsentativ og tilstrækkelig (større end $70 \%$ ).

\section{Resultater}

Her følger en beskrivelse af udbredning af patientsikkerhedskulturundersøgelse hos medarbejdere på sygehuse i de nordiske lande. Oplysningerne er indsamlet i sidste kvartal af 2009.

Danmark har oversat og valideret et af de hyppigst anvendte internationale spørgeskemaer (AHRQ). Spørgeskemaet er i øjeblikket i praktisk pilottest. Herudover har der fra 2003 til 2006 været anvendt egenudviklede surveys. I 2006 gennemførtes en undersøgelse omfattende mere end 10.000 medarbejdere i hovedstadsområdet. Herudover er der gennemført mindre undersøgelser med andre survey.

Finland gennemfører et projekt på Kuopio universitet, baseret på AHRQsurvey og VTT (Statens tekniska forskningscentral) arbejder med eget skema i forbindelse med udvikling af patientsikkerhedskultursmåling.

Færøerne har ikke på nuværende tidspunkt planer om at tage patientsikkerhedskultur surveys i brug.

Grönland har ikke på nuværende tidspunkt planer om at tage patientsikkerhedskultur surveys i brug.

I Island har man i perioden 2005-2007 anvendt AHRQ-survey på medicinsk-kirurgiske, operations- og intensivafdelinger på Landspitali University Hospital i Reykjavík. AHRQ-survey er desuden anvendt på 5 islandske hospitaler i 2007. I 2009 har man anvendt SAQ på operationsafdelingen, Landspitali University Hospital i Reykjavík.

I Norge er der foretaget oversættelse, detaljeret validering og afprøvning af de to internationalt hyppigst anvendte surveys (AHRQ og SAQ). SAQ anvendes rutinemæssigt på afdelinger på ét universitetssygehus. 
Sverige har oversat og valideret AHRQ-survey. Survey er afprøvet på 3000 personer indenfor seks landsting i et fælles projekt mellem Socialstyrelsen og landstingene.

I alle de nordiske lande er anvendelsen af patientsikkerhedssurvey som forbedringsinstrument enten foregået på enkelte institutioner eller indenfor enkelte regioner. Anvendelsen er sket indenfor relativt begrænset tidsrum, således, at udvikling over tid endnu ikke kan dokumenteres.

Hvordan kulturindikatoren kan komme i anvendelse som nordisk indikator fremgår af tabell 2 nedenfor.

Tabell 2. Indikatorens anvendelse som nordisk indikator

\begin{tabular}{|c|c|c|c|}
\hline \multirow[t]{2}{*}{ Land } & \multicolumn{3}{|c|}{$\begin{array}{l}\text { Indikatorns namn: Andelen af sygehuse, der anvender patientsikkerhedskulturmåling i } \\
\text { forbedringsarbejde }\end{array}$} \\
\hline & $\begin{array}{l}\text { Plan för hur indikatorn ska komma } \\
\text { till användning }\end{array}$ & $\begin{array}{l}\text { Organisation som kan sam- } \\
\text { manställa data }\end{array}$ & $\begin{array}{l}\text { När indikatorn } \\
\text { beräknas vara i } \\
\text { bruk }\end{array}$ \\
\hline Danmark & $\begin{array}{l}\text { Anvendes nationalt/regionalt } \\
\text { som mål for udbredning af } \\
\text { patientsikkerhedskulturmålinger }\end{array}$ & $\begin{array}{l}\text { National platform for pati- } \\
\text { entsikkerhed (EUNetPaS) = } \\
\text { Dansk Selskab for Patient- } \\
\text { sikkerhed }\end{array}$ & 2011 \\
\hline Finland & $\begin{array}{l}\text { Nationella patientsäkerhets- } \\
\text { strategin }\end{array}$ & $\begin{array}{l}\text { Institutet för hälsa och } \\
\text { välfärd }\end{array}$ & 2013 \\
\hline \multicolumn{4}{|l|}{ Färöarna } \\
\hline \multicolumn{4}{|l|}{ Grönland } \\
\hline \multicolumn{4}{|l|}{ Island } \\
\hline Norge & Nasjonal indikator & $\begin{array}{l}\text { Enhet för pasientsikkerhet, } \\
\text { Kunnskapssenteret }\end{array}$ & 2011 \\
\hline Sverige & Regionalt og nationalt & $\begin{array}{l}\text { Socialstyrelsen/Sveriges } \\
\text { Kommuner og Landsting }\end{array}$ & 2012 \\
\hline
\end{tabular}

\section{Definitioner og diskussion}

Indikatorens formål er måling af udbredning af patientsikkerhedskultursurveys i de nordiske lande. Indikatoren er specificeret med henblik på anvendelse indenfor forbedringsarbejde med fokus på klinisk team, klinisk afdelingsniveau. Indikatoren er derfor detailspecificeret med henblik på korrekt anvendelse. 
Tæller

Antallet af somatiske akut modtagende sygehuse i landet, som anvender validerede patientsikkerhedskultur(klima)surveys, der opfylder basale krav til antallet af dimensioner jævnfør EUNetPaS afrapportering (69-70). Anvendelsen sker i forbindelse med:

- På forhånd fastlagt plan i forhold til opfølgning og interventioner

- Protokol for kommunikation og fortolkning af resultatet i forhold til medarbejderne på det kliniske niveau, som survey omfatter

- Først og fremmest på klinisk teamniveau

- Flere successive målinger (1-3 års intervaller)

- På forhånd speciciferet acceptabel deltagelsesprocent.

Nævner

Totalt antal akut-modtagende somatiske sygehuse. Projektgruppen finder, at der mangler definition på begrebet "akut sygehuse”. I flere nordiske lande er der dog etableret pragmatiske definitioner på sygehusenhed. I Sverige kan man anvende samme slags afrapportering som i Öppna Jämførelser, og i Danmark kan nævnerproblematikken løses indenfor rammerne af Den Danske Kvalitetsmodel. For at omgå disse vanskeligheder foreslår projektgruppen, at hvert nordisk land anvender egne sygehusdefinitioner og afrapporterer svarende til følgende kategorier:

- Metoden anvendes ikke

- Mellem 1-25 \% af somatiske akut-sygehuse anvender metoden

- Over $25 \%$ og mindre end $50 \%$ af somatiske akut-sygehuse anvender metoden

- Over $50 \%$ og mindre end $75 \%$ af somatiske akut-sygehuse anvender metoden

- Over $75 \%$ af somatiske akut-sygehuse anvender metoden. 


\subsection{Sjukhusmortalitet}

\subsubsection{Måling af mortalitetsrater på hospitalsindlagte patienter}

\section{Indikatorens betydning}

Siden 1800-tallet har kvalitativ auditbaseret undersøgelse af dødsfald i forbindelse med hospitalsindlæggelse, sammen med kvantitativ analyse af mortalitetsrater under og kort tid efter hospitalsindlæggelse, spillet en væsentlig rolle i afdækning af kvalitets- og patientsikkerhedsbrister (71-74).

Med den stigende opmærksomhed på betydningen af patientsikkerhed, er interessen for analyse af dødsfald intensiveret. Specielt er dette begrundet $\mathrm{i}$ en lang række af undersøgelser af forekomsten af utilsigtede hændelser (behandlingsrelaterede patientskader), hvor der konstateredes et ikke-ubetydeligt antal patientdødsfald.

I Danmark estimeres dette antal til at være cirka 5000 pr. år, hvoraf halvdelen må anses for at være forebyggelige (75). Det er derfor naturligt, at måling af mortalitet i forbindelse med hospitalsindlæggelse har fået særlig betydning som generisk resultatindikator i forhold til måling af niveau for patientsikkerhedsproblemer eller effekt af patientsikkerhedsinterventioner.

Anvendelse af mortalitetsrater som generiske indikatorer for sygehuspatientsikkerhedsniveau stiller imidlertid basale metodologiske krav: robust korrektion for variationer af casemix (over tid og mellem hospitaler) samt fokus på forebyggelige dødsfald.

Disse metodologiske krav honoreres ved selektion af særlige patientgrupper: Ved hospitalsstandardiseret mortalitetsrate (HSMR), beregnes mortalitetsrater hos patientgrupper med højeste antal dødsfald umiddelbart i forbindelsee med indlæggelse, således at der redegøres for størstedelen (80\%) af dødsfald på hospital eller 30 dage efter indlæggelse (9,10,76-78) på landsplan. Ved indikatoren "Death in low mortality DRGs” måles dødsfald på hospital eller inden for 30 dage efter indlæggelse hos patientgrupper defineret via DRG-grupper med særlig lav mortalitet (79).

Udover patientselektion baseret på stratificering indeholder metoderne korrektion for casemix-forhold, som for eksempel alder, køn, indlæggelsesmåde, komorbiditet. Resultater angives enten som absolutte værdier eller som ratio observerede/forventede dødsfald, hvor forventede dødsfald udgøres af gennemsnitsværdien for hele populationen (nationen). 
Internationalt er metoderne udbredt i USA, Canada, Australien, UK, Holland og Frankrig. Metoderne anvendes dels til løbende monitorering og forbedringsarbejde, dels som effektmåling i kampagner, som i "100,000 lives” i USA.

\section{Videnskabeligt grundlag}

På trods af den store udbredelse af såvel HSMR som tilsvarende mortalitetsindikatorer viser en litteraturgennemgang, at grundlaget for at anvende mortalitetsanalysen til sammenligning af patientsikkerhedsniveauet på hospitaler er spinkelt. For HSMRs vedkommende er der fra flere sider rejst indvending mod kvaliteten af justering for confounders og casemix $(10,80-82,85)$.

På trods af et omfattende metodeudviklingsarbejde med sofistikeret justering for prognostiske faktorer på enkeltpatientniveau og anvendelse af avanceret statistisk proceskontrol metode til detektion af signifikante forandringer, er resultaterne påvirkelige af kodekvalitet i de patientadministrative registre, andelen af patienter, der på et givent sygehus er indlagt til palliation, forholdet mellem dødsfald på sygehus og det totale antal dødsfald i sygehusets optageområde.

Der kan ligeledes konstateres systematiske forskelle mellem HSMRværdier på "tertiary care” universitetshospitaler og regionale hospitaler.

Det har yderligere været vanskeligt at påvise sammenhæng mellem kvalitet/patientsikkerhed, målt med alternative metoder og hospitalsstandardiseret dødelighed.

Tilsvarende forhold synes at gøre sig gældende for indikatoren "Death in low-mortality DRGs (11). Samtidig er det absolutte antal dødsfald inden for denne kategori på sygehuse i Norden (og USA) så lavt, at indikatoren kun giver mening på regionalt - nationalt niveau.

Kritik af hospitalsmortalitetsrater (HSMR eller death in low-mortality DRGs) har udløst omfattende debat. Det kan for det første konkluderes, at der ikke er overbevisende evidens for at disse indikatorer kan benyttes til retvisende sammenligning mellem hospitaler. På den anden side kan det også konstateres, at disse målinger har stimuleret genoptagelse af kvalitative, altså ikke-kvantitative, auditbaserede undersøgelser af dødsfald på hospitaler $(83,84)$. Måling af mortalitetsrater på hospitaler må derfor betegnes som potentielt anvendeligt $\mathrm{i}$ internt forbedringsarbejde i forhold til patientsikkerhed. Indikatorerne kan med de begrænsninger, der ligger i de nuværende metoder, 
næppe anvendes til benchmarking mellem hospitaler, og ingenlunde til national sammenligning (85).

\section{Resultater}

Måling af hospitalsstandardiseret dødelighed med regelmæssig offentliggørelse af resultater på hospitalsniveau har været rutine i Danmark siden Operation Life projektets igangsættelse i 2007. Metoden er fortsat i anvendelse, og der foregår aktiv forskningsbaseret udvikling af såvel risikojustering som procesanalyse.

I Sverige er der foretaget en kritisk gennemgang af metoden på nationalt niveau med udgangspunkt i patientregisterdata 1998-2005. Resultatet af denne kritiske gennemgang har været, at metoden fandtes uegnet til sammenligning mellem sygehuse og regioner på nationalt niveau. Der foregår stadig udviklingsarbejde og forbedringsarbejde med udgangspunkt i hospitalsstandardiseret mortalitet i enkelte landsting.

Death in low-mortality DRGs indikatoren er blevet undersøgt via det svenske patientregister og det danske landspatientregister i forbindelse med undergruppens virksomhed. Man konstaterer her, at der i begge lande ses betydende regionale forskelle. Det absolutte antal dødsfald, der indgår i beregning, er imidlertid så lavt, at det ikke er muligt at gennemføre meningsfuld sammenligning på hospitalsniveau.

Det kan desuden konstateres, at der er så store forskelle i den danske DRG-klassifikation og den nordiske DRG-klassifikation, at et særligt udviklingsarbejde med deltagelse af såvel epidemiologisk som klinisk ekspertise er nødvendigt for at give grundlag for denne indikator.

\section{Overvejelse om indikatorer}

På baggrund af litteraturens reservationer overfor metodens anvendelighed til sammenligning mellem enheder, samt på baggrund af specifikke nationale erfaringer, finder gruppen ikke, at standardiserede mortalitets-rater kan anvendes i det nordiske indikatorsæt. Det tilrådes, at man frem for at anvende generiske institutionsrelaterede mortalitetsanalyser i stedet fokuserer på diagnose/indgrebsspecifikke case fatality rates med udgangspunkt i og videreudvikling af OECD-indikatorerne på nordisk plan. 


\subsection{Vårdrelaterade infektioner}

Med unntak av indikatoren "andel enerom med toalett” er alle de foreslåtte indikatorene også anbefalt å jobbe videre med av en europeisk arbeidsgruppe, som inngår i Improving Patient Safety in Europe (IPSE) prosjektet.

\subsubsection{Terminologi}

I dette dokumentet er betegnelsen nosokomial infeksjon, sykehusinfeksjon og helsetjeneste-assosiert infeksjon (HAI) brukt som synomyme begreper. Internasjonalt er det en klar trend i retning av å benytte begrepet HAI. Dette skyldes endringer i helsetjenesten, der det med årene er blitt en uskarp grense mellom klassiske sykehusinnlagte pasienter og pasienter som undersøkes og behandles med dagopphold og polikliniske konsultasjoner. Mye av den helsetjenesten som tidligere ble knyttet til innleggelse foregår nå uten innleggelse. Følgende indikatorer blir omtalt i dette dokumentet:

Strukturindikatorer:

a. Smittevernpersonell

b. Enerom med toalett

Prosessindikatorer:

c. Insidensregistrering av infeksjoner i operasjonsområdet

d. Prevalensregistrering av helsetjeneste-assosierte infeksjoner

e. Forbruk av hånddesinfeksjonsmidler

f. Etterlevelse av regler for håndhygiene.

\subsubsection{Smittvernspersonell}

\section{Indikatorens betydning}

Bruk av eget personell til å kartlegge og forebygge infeksjoner i sykehus har sin opprinnelse i de store problemene man hadde med stafylokokkinfeksjoner i sykehus over hele verden på 1950-tallet. Sykehusene begynte da å ansette smittevernleger (infection control officer/hospital epidemiologist) og hygienesykepleiere (infection control sister/infection control nurse) (86). Dette skjedde også i nordiske sykehus utover 1960-tallet. I USA anbefalte Centers for 
Disease Control and Prevention (CDC) en bemanning på 1 hygienesykepleier per 250 somatiske sykehussenger (87).

\section{Vitenskapelig belegg}

Omkring 1980 ble det satt i gang en omfattende evaluering av kostnadseffektivitet og kostnytteverdi av infeksjonskontrollprogram i USA: Study on the Efficacy of Nosocomial Infection Control (SENIC project). Resultatene ble publisert i 1985 og beskrev hvilke komponenter som var nødvendige i et effektivt infeksjonskontrollprogram (88-90). Det ble dokumentert en sammenheng mellom struktur- og prosessparametre og effekt på forekomst av sykehusinfeksjoner.

Det ble blant annet dokumentert, at det var nødvendig med 1 fulltidsarbeidende hygienesykepleier per 250 senger og en lege med spesiell kompetanse i smittevern på hvert sykehus. Oppdaterte analyser av behovet for smittevernpersonell har vært publisert blant annet fra USA (2002, 2009), Canada (2004) og Nederland (2007) (91-94).

\section{Resultat}

Beskrivelse av dagens bruk av indikatoren og mulig fremtidig bruk.

Danmark: Denne indikator er ikke etableret i Danmark.

Finland: I Finland, er det gjennomført to undersøkelser av smittevernressurser og aktiviteter i akuttsykehus, én i 2000 og en tidlig i 2009. I 2009 svarte alle 57 (100 \%) sykehus: 5 tertiære (inkludert 16 separate sykehus), 15 sekundære og 26 primærsykehus. $70 \%$ av sykehusene hadde spesialist i infeksjonssykdommer og $37 \%$ hadde klinisk mikrobiolog som begge deltok i smittevernarbeidet. De brukte en median på $10 \%$ (range, 1-66 \%) av arbeidstiden til infeksjonskontroll. Blant sykehusene hadde $89 \%$ en trenet hygienesykepleier. Hygienesykepleierne brukte en median på 70 \% (range 25-100 \%) av arbeidstiden på infeksjonskontroll i sitt eget sykehus. Median antall sykehussenger per fulltids hygienesykepleier var 257 (range, 87-770).

Ved $16 \%$ av sykehusene var det teknisk støtte og $30 \%$ hadde sekretærstøtte. De fleste sykehusene (95\%) hadde infeksjonskontrollkommitté og et system med kontaktsykepleiere (link nurse) for hele sykehuset (96 \%). Alle sykehusene utførte insidensregistrering for minst én spesialitet, oftest av infeksjoner i operasjonsområde (surgical site infections) (83\%). Etter den nasjonale prevalensregistreringen i 2005, har $66 \%$ av sykehusene gjentatt prevalensregistrering for hele sykehuset. 
Sammenlignet med resultatene fra 2000, har antallet hygienesykepleiere økt (2000: range 394-953 senger per hygienesykepleier; 2009: range 87-770, median 257). Med adekvat bemanning bør fokus være på ytterligere trening og evaluering av hygienesykepleiernes curriculum. Selv om de fleste sykehusene hadde leger som deltok i infeksjonskontrollprogrammet, var deres bidrag til infeksjonskontrollen begrenset, slik som i 2000.

Med en ganske god status med hensyn til infeksjonsregistrering bør fokus skiftes til å bruke resultatene av infeksjonsregistreringen, heller enn å starte ny registrering. I fremtiden kan deler av denne kartleggingen oppdateres med web-baserte spørreundersøkelser, og resultatene benyttes ved planlegging av nasjonale struktur og prosessindikatorer for smittevern $(95,96)$.

Færøyene: Indikatorerne anvendes ikke. Der er tre sygehuse på Færøerne. Landssygehuset er det største og råder over ca. 200 senge, inklusive psykiatrien. Siden 2006 har regelmæssig registrering af MRSA tilfælde fundet sted sideløbende med MRSA screening af samtlige patienter, der har været indlagt på udenlandske hospitaler. Incidensregistrering af postoperative sårinfektioner med angivelse af fire risikofaktorer er blevet gennemført i perioden maj 2009 til maj 2010. Resultatet er ikke opgjort.

En kombineret spørgeskemaundersøgelse og observationsundersøgelse af sundhedspersonales brug af smitteforebyggende tiltag relateret til deres vurdering af egen og patienternes smitterisiko bliver gennemført i juni 2010.

Formaliseret kursusvirksomhed i sygehushygiejne finder sted to gange årligt. Derudover gives ad hoc undervisning i de enkelte kliniske afsnit. Hygiejnesygeplejerske har været ansat siden december 2006.

Grønland: På landssygehuset Dronning Ingrids Hospital med 280 senge findes en hygiejneorganisation med landsdækkende funktion. Rådgivning fra smittevernlæge og bistand fra hygiejnesygeplejerske modtages efter behov i henhold til aftale med Statens Serum Institut.

Norge: I Norge inneholder de regionale smittevernplanene (4 regioner) data om smittevernpersonell.

Sverige: Indikatorn är inte färdigutvecklad (se under definisjoner og begrunnelse) och används därför inte. 
Tabell 3. Plan for hvordan indikatoren skal brukes i hvert land

\begin{tabular}{llll}
\hline Land & $\begin{array}{l}\text { Plan för hur indikatorn ska } \\
\text { användas }\end{array}$ & $\begin{array}{l}\text { Organisation som kan samman- } \\
\text { ställa data }\end{array}$ & $\begin{array}{l}\text { När indikatorn } \\
\text { beräknas vara i bruk }\end{array}$ \\
\hline Danmark & Sykehusnivå & SSI/DSFH/DSKM & ikke planlagt \\
Finland & Sykehusnivå & Institutet för hälsa och välfärd & 2011 \\
Färöarna & Sykehusnivå & SSI, DSFH & 2011 \\
Grönland & Landssykehusnivå & Sundhedsledelsen & 2011 \\
Island & & & \\
Norge & Sykehusnivå & Helsedirektoratet & 2011 \\
Sverige & Indikatorn kan prövas när & & \\
& den är färdigutvecklad. & & \\
\hline
\end{tabular}

Definisjoner og begrunnelse

\section{Leger}

Definisjonen av, og funksjonen til smittevernlege/hygienelege kan variere. Noen leger har smittevern som fulltids beskjeftigelse, mens mange har ansvar for smittevern som en deltidsoppgave i tillegg til for eksempel mikrobiologi eller infeksjonsmedisin. En forutsetning for å kunne bruke dette som en indikator vil derfor være en standardisert angivelse av omfanget av deltidsfunksjonen. Det mest hensiktsmessige vil trolig være å angi dette som antall timer per uke, måned eller år (i stedet for en andel av en stilling), for å korrigere for ulikheter i total arbeidstid mellom sykehus og over landegrenser. Forslag til teller: Det foreslås at bemanning med smittevernlege(r) angis som antall arbeidstimer brukt til smittevernarbeid per år.

\section{Sykepleiere}

Definisjonen av hygienesykepleier vil trolig være nokså lik i de nordiske land. Forslag til teller: Det foreslås at bemanning med hygienesykepleier(e) angis som antall arbeidstimer brukt til smittevernarbeid per år.

\section{Andre personellgrupper som utfører smittevernoppgaver}

Mange arbeidsoppgaver som utføres av smittevernleger og hygienesykepleiere kan også utføres av personell med annen yrkesutdanning.

Andre personellgrupper som kan være involvert i smittevernarbeid er blant annet kontorpersonell, IT-personell, laboratoriepersonell, ingeniører og hygienombud. Der slike finnes må de derfor tas med i regnestykket. 
Forslag til teller: Det foreslås at bemanning annet smittevernpersonell angis som antall arbeidstimer brukt til smittevernarbeid per år.

Oppgaver som utføres av smittevernpersonell

Arbeidsoppgavene som utføres av smittevernleger og hygienesykepleiere kan variere fra sykehus til sykehus og over landegrensene. Det gjelder for eksempel vaksinasjon, oppfølging av stikkskader og smitteoppsporing blant helsepersonell. Dette utføres noen steder av hygienesykepleiere, mens andre sykehus har organisert denne virksomheten i tilknytning til en arbeidsmiljøtjeneste, eller bedriftshelsetjeneste i egen regi eller kjøpt hos eksterne aktører.

Det er også stor variasjon når det gjelder omfanget av arbeid knyttet til primærhelsetjenesten, inkludert sykehjem og andre helseinstitusjoner. Det må derfor etableres en metode for korrigere for disse ulikhetene dersom bemanning skal brukes som en indikator. Det foreslås, at det bare er personellressurser, som utfører arbeidsoppgaver som er rettet mot forebygging og kontroll av infeksjoner ved helseinstitusjonen/sykehuset-/sykehjemmet som tas med i telleren.

Dette vil inkludere forberedelse av pasienter før innleggelse og oppfølging av pasienter etter utskrivelse, eller polikliniske konsultasjoner, inkludert infeksjonsregistrering etter kirurgiske inngrep og andre prosedyrer utført ved det aktuelle sykehuset. Men det vil ikke omfatte personellressurser brukt til ren bistand til primærhelsetjenesten for pasienter, som ikke skal eller har vært behandlet av sykehuset. 
Tabell 4. Forslag til aktiviteter som skal regnes som smitteforebyggende arbeid

\begin{tabular}{|c|c|}
\hline Infeksjonsovervåking & $\begin{array}{l}\text { Planlegge og utforme overvåking } \\
\text { Datainnsamling: kirurgi, utstyr, risikogrupper, infeksjoner } \\
\text { Behandle rapporter } \\
\text { Analysere og tolke overvåkingsdata } \\
\text { Rapportere resultater } \\
\text { Intervensjoner på grunnlag av overvåking }\end{array}$ \\
\hline $\begin{array}{l}\text { Epidemiologiske undersøkelser } \\
\text { og utbruddshåndtering }\end{array}$ & $\begin{array}{l}\text { Smitteoppsporing } \\
\text { Undersøke utbrudd } \\
\text { Rapportere resultater } \\
\text { Genotyping av mikrorganismer for epidemiologiske formål } \\
\text { Identifisere reservoarer } \\
\text { Identifisere pasienter med infeksjon } \\
\text { Gi råd om testing } \\
\text { Tolke testresultater } \\
\text { Organisere prøvetaking }\end{array}$ \\
\hline Forebygge smitteoverføring & $\begin{array}{l}\text { Utvikle og revidere smittevernpolitikk og -prosedyrer } \\
\text { Utvikle og gjennomføre planer for } \\
\text { håndhygiene og antisepsis } \\
\text { rengjøring, desinfeksjon og sterilisering } \\
\text { påvisning av variasjon og avvik mht. infeksjonskontroll } \\
\text { infeksjonsforebygging i pasientmiljø } \\
\text { infeksjonsforebygging utenfor pasientmiljø } \\
\text { prosedyrer og utstyr } \\
\text { smitteavfall } \\
\text { utstyr og forsyninger } \\
\text { aktiviteter forbundet med (multi) resistente mikroorganismer }\end{array}$ \\
\hline $\begin{array}{l}\text { Helse, miljø og sikkerhet for } \\
\text { personell }\end{array}$ & $\begin{array}{l}\text { Forebygging av smitte fra pasienter til personell } \\
\text { Forebygging av stikkskader og oppfølging av disse } \\
\text { Vaksinasjon av helsepersonell }\end{array}$ \\
\hline $\begin{array}{l}\text { Organisere, administrere og } \\
\text { formidle infeksjonskontrollpro- } \\
\text { gram }\end{array}$ & $\begin{array}{l}\text { Programplanlegging } \\
\text { Utvikling og implementering av retningslinjer, prosedyrer og } \\
\text { protokoller } \\
\text { Anbefale infeksjonskontrollprogram, utstyr og personell } \\
\text { Tilsyn/revison/audit og andre aktiviteter for å evaluere ret- } \\
\text { ningslinjer, protokoller og praksis } \\
\text { Aktiviteter forbundet med sykdomer som er meldepliktige (for } \\
\text { eksempel tuberkulose) } \\
\text { Kostnytteanalyser og produktevaluering } \\
\text { Rådgiving i byggesaker og renovasjon } \\
\text { Rådgiving om renhold } \\
\text { Spre informasjon om smittevern til institusjoner } \\
\text { Delta i kvalitetsforbedring knyttet til smittevern } \\
\text { Bidra til etterlevelse av lover og forskrifter om smittevern } \\
\text { Bidra ved akkreditering/lisensiering vedrørende smittevern } \\
\text { Forskning i smittevern }\end{array}$ \\
\hline Undervisning og opplæring & $\begin{array}{l}\text { Kartlegge behov for opplæring blant helsepersonell } \\
\text { Lede opplæring i infeksjonsforebygging } \\
\text { Utvikle undervisningsmateriell } \\
\text { Gjennomføre undervisning og trening } \\
\text { Evaluere resultatet av opplæring } \\
\text { Veiledning av smittevernpersonell under opplæring }\end{array}$ \\
\hline
\end{tabular}




\section{Nevner}

Det er en utfordring å finne frem til en standardisert nevner når det gjelder å bruke bemanning som strukturindikator. For det første er det nødvendig å etablere en enhetlig definisjon av sykehus (somatisk sykehus med akuttfunksjon, somatisk langtidsinstitusjon, psykiatrisk institusjon). Det er også nødvendig å etablere en standardisert definisjon på en sykehusseng, spesielt hvis man skal bruke denne indikatoren til sammenligning over landegrensene.

På bakgrunn av den driftsendring som har skjedd i helsevesenet de siste årene, vil heller ikke antall senger alene være en tilstrekkelig referanse. Trolig bør også antall pasientopphold eller et tilsvarende mål på aktivitet være hensiktsmessig i tillegg.

Følgende nevnere foreslås: Man bruker både antall sykehussenger, antall innleggelser og antall liggedøgn per år som nevnere.

\section{Tabell 5. Beskrivning af indikator}

\begin{tabular}{ll}
\hline Beskrivelse av indikatoren & Bemanning med smittevernpersonell \\
\hline Indikatorens teller: & $\begin{array}{l}\text { Antall timer per år for hygienesykepleiere, smittevernleger og } \\
\text { annet smittevernpersonell.rettet mot infeksjonsforebyggende } \\
\text { arbeid i sykehuset (arbeid rettet mot sykehjem/ primærhelsetjenes- } \\
\text { ten regnes bare med når det gjelder felles pasienter) }\end{array}$ \\
Indikatorens nevner: & $\begin{array}{l}\text { Antall sykehussenger, respektive antall innleggelser og antall } \\
\text { liggedøgn. }\end{array}$ \\
Nivå: & Landsnivå. Sykehusnivå. \\
\hline
\end{tabular}

\subsubsection{Enerom med toalett}

\section{Indikatorens betydning}

Pasienter blir ofte innlagt i sykehus med infeksjoner som kan overføres til medpasienter og personalet. I tillegg utvikler mange pasienter en helsetjenesteervervet infeksjon. Enerom med eget toalett representerer en fysisk barriere og reduserer dermed risikoen for smittespredning. Ved mange infeksjonssykdommer, for eksempel mage-tarm-infeksjoner, vil isolering i enerom være tilstrekkelig. Isolering av smittebærende pasienter i enerom er derfor et aktuelt smitteverntiltak. I tillegg vil det for pasienter med enkelte smittsomme sykdommer være behov for mer avansert form for isolering, for eksempel i form av luftsmitteisolat. 


\section{Vitenskapelig belegg}

Det finnes ikke publisert litteratur som direkte måler effekten av andelen av enerom, som eneste tiltak, på insidensraten av sykehusinfeksjoner. Men det finnes en rekke publikasjone,r som viser at isolering i enerom sammen med andre forebyggende tiltak slik som bruk av beskyttelsesfrakk, hansker o.a. bidrar til redusert smittespredning (97). Retningslinjer fra en rekke land og ulike fagmiljøer legger også vekt på enerom, som en viktig premiss for å hindre kryssmitte i sykehus (98-100). Men det er ikke konsensus om hvor stor andel av enerom, som er nødvendig for optimal forebygging av kryss-smitte.

\section{Resultat}

Beskrivelse av dagens bruk av indikatoren og mulig fremtidig bruk.

Danmark: Indikatoren ikke etableret i Danmark.

Finland: Basert på den ovenfor nevnte kartleggingen i 2009 var det 189 isolasjonsrom med sluse, eget toalett/dusj og undertrykk i hele landet og 32 av disse var lokalisert til intensivenheter. Dette er mer enn det som ble registrert i de foregående undersøkelsene av dette i 2003 (66/19) og 2006 (145/20) $(101,102)$.

Fcrøyene: Enestuer med eget toilet findes ikke på Landsygehuset, men tosengsstuer anvendes i isolationsøjemed efter behov. Behovet for enestuer på medicinsk afdeling med eget bad og toilet på Landsygehuset forventes indfriet i forbindelse med et planlagt nybyggeri. På et af de mindre sygehuse Suderø sygehus, findes enestue med toilet og bad og urent skyllerum.

Grønland: Indikatoren kan anvendes på Landssygehusniveau.

Norge: Slike data er registrert i smittevernplanene for de fire norske helseregionene.

Sverige: Indikatorn används inte för närvarande. Det saknas för närvarande konsensus kring vilken nivå som är optimal, bra eller acceptabel. 
Tabell 6. Plan for hvordan indikatoren skal brukes i hvert land

\begin{tabular}{|c|c|c|c|}
\hline Land & $\begin{array}{l}\text { Plan för hur indika- } \\
\text { torn ska användas }\end{array}$ & Organisation som kan sammanställa data & $\begin{array}{l}\text { När indikatorn } \\
\text { beräknas vara i bruk }\end{array}$ \\
\hline Danmark & Sykehusnivå & SSI & ikke planlagt \\
\hline Finland & Sykehusnivå & Institutet för hälsa och välfärd & 2011 \\
\hline Färöarna & Sykehusnivå & $\begin{array}{l}\text { SSI, hygiejneorganisationen ved det } \\
\text { færøske sundhedsvæsen }\end{array}$ & \\
\hline Grönland & Landssykehusnivå & Sundhedsledelsen & 2011 \\
\hline \multicolumn{4}{|l|}{ Island } \\
\hline Norge & Sykehusnivå & Helsedirektoratet & 2011 \\
\hline Sverige & $\begin{array}{l}\text { Indikatorn kan } \\
\text { prövas när den är } \\
\text { färdigut-vecklad. }\end{array}$ & $\begin{array}{l}\text { Sveriges Kommuner och Landsting och } \\
\text { Socialstyrelsen }\end{array}$ & \\
\hline
\end{tabular}

\section{Definisjoner og begrunnelse}

Det finnes mange ulike kombinasjoner av enerom, med og uten bad/WC, med og uten forgang/sluse osv, isolat med kontrollert ventilasjon. Det vil være for komplisert å bruke en rekke ulike kategorier enerom som teller i en slik indikator, og gruppen mener derfor, at man bør samle de ulike typene av slike rom i én kategori: enerom med eget tilknyttet WC (som inkluderer alle kombinasjoner av bad/WC). Dette vil også inkludere isoleringsrom med forgang/sluse.

Indikatorens teller og nevner må standardiseres: Det er nødvendig å etablere en standardisert definisjon på hva som skal regnes som en sykehusseng, spesielt hvis man skal bruke denne indikatoren til sammenligning over landegrensene.

Tabell 7. Beskrivning af indikatoren

\begin{tabular}{ll}
\hline Beskrivning av indikatoren: & Andel enerom med eget toalett i forhold til totalt antall senger i sykehuset. \\
Indikatorens teller: & Antall enerom med eget toalett. \\
Indikatorens nevner: & Antall pasientsenger totalt \\
Nivå: & Landsnivå. Sykehusnivå. \\
\hline
\end{tabular}




\subsubsection{Insidensregistrering av infeksjoner i operasjonsområdet}

\section{Indikatorens betydning}

Infeksjoner i operasjonsområdet etter kirurgiske inngrep oppstår hos 2-5 \% av opererte pasienter og utgjør 15-25\% av sykehusinfeksjonene. En stor andel av infeksjonene manifesterer seg først etter at pasientene er utskrevet. Kostnadene kan være betydelige.

\section{Vitenskapelig belegg}

SENIC-studien dokumenterte at infeksjonsregistrering er et viktig element i et effektivt infeksjonskontrollprogram. Dette gjelder ikke minst infeksjoner etter kirurgiske inngrep med aktiv bruk av data, inkludert tilbakemelding til den enkelte kirurg (87-90). Dette er også verifisert i senere studier (99,103). Siden mer enn halvparten av infeksjoner etter kirurgiske inngrep manifesterer seg etter utskrivelse, er det vesentlig å følge pasientene også etter utskrivelse $(99,104)$. I tillegg til å ha en smitteverneffekt, er også kohortovervåking sentralt for å kunne si noe om effekt av andre smitteverntiltak.

\section{Resultat}

Norge og Finland har tilsvarende systemer for kohortundersøkelser, hvor metodikken er basert på en europeisk mal utarbeidet av Hospital In Europe Link for Infection Control through Surveillance (HELICS).

Danmark: Systematisk registrering finder ikke sted for nærværende. Der er ikke nærmerede defineret indikatorer, men fra 2011 skal alle sygehuse, som led i den danske kvalitetsmodel, overvåge nosokomielle infektioner. Desuden skal udvikling af antibiotikaresistens og antibiotikaforbrug overvåges.

Finland: Det finske Infeksjonskontrollprogrammet (SIRO) startet i slutten av 1997 som et samarbeidsprosjekt mellom det nasjonale folkehelseinstituttet (THL, tidligere KTL) og fire utvalgte sykehus. Det har vært finansiert av THL og departementet for sosiale saker og helse. Tre pågående overvåkingsmoduler ble utviklet, inkludert sykehusomfattende overvåking av nosokomiale infeksjoner i blodbanen (fra september 1998), Clostridium difficile infeksjoner (fra januar 2008) og infeksjoner i operasjonsområdet ved 10 utvalgte kirurgiske prosedyrer (fra januar 1999: hofte- og kneproteser, femurfrakturer og koronarkirurgi; fra januar 2003: abdominale hysterectomier, appendectomier, mammakirurgi og keisersnitt; from 2008: laminectomi). For tiden deltar 15 
sykehus med registrering av infeksjoner i operasjonsområdet for minst én prosedyregruppe.

Færøyene: Insidensregistrering af postoperative sårinfektioner på Landssygehuset siden maj 2009.

Grønland: Der findes ikke nogen samlet registrering af helsetjenste associerede infektioner sted idag, men der er et intentioner om at iværksætte registrering.

Norge: har et veletablert nasjonalt system for kohortundersøkelser, hvor metodikken er basert på en europeisk mal urarbeidet av HELICS.

Sverige: Många opererande kliniker har en postoperativ uppföljning under 30 dagar för att identifiera vårdrelaterade infektioner. Inom vissa specialiteter finns postoperativa sårinfektioner dokumenterade i kvalitetsregister. Någon samlad bild av hur läget är i landet finns för närvarande inte.

Tabell 8. Plan for hvordan indikatoren skal brukes i hvert land

\begin{tabular}{llll}
\hline Land & $\begin{array}{l}\text { Plan för hur indika- } \\
\text { torn ska användas }\end{array}$ & $\begin{array}{l}\text { Organisation som kan sammanställa } \\
\text { data }\end{array}$ & $\begin{array}{l}\text { När indikatorn beräknas } \\
\text { vara i bruk }\end{array}$ \\
\hline Danmark & Sykehusnivå & IKAS & Ikke planlagt \\
Finland & Sykehusnivå & Institutet för hälsa och välfärd & 2011 \\
Färöarna & Sykehusnivå & Hygiejneorganisationen & Siden 2009 \\
Grönland & Landssykehusnivå & Sundhedsledelsen & 2011 \\
Island & & & \\
Norge & Sykehusnivå & Nasjonalt folkehelseinstitutt & 2011 \\
Sverige & Sykehusnivå & Kommuner och Landsting & 2012 \\
\hline
\end{tabular}

\section{Definisjoner og begrunnelse}

Det er dokumentert i vitenskapelige studier at infeksjonsregistrering etter kirurgi med tilbakemelding til den enkelte kirurg har en infeksjonsforebyggende effekt i seg selv. Infeksjonsregistreringen bør omfatte de første 30 dager etter inngrepet (104).

Tabell 9. Bekrivning af indikatoren

\begin{tabular}{ll}
\hline Beskrivning av indikatoren: & $\begin{array}{l}\text { Insidensregistrering av infeksjoner i operasjonsområdet (surgi- } \\
\text { cal site infections) }\end{array}$ \\
Indikatorens teller: & $\begin{array}{l}\text { Antallet kirurgiske inngrep som følges opp i minst } 30 \text { dagar } \\
\text { postoperativt.med registrering av infeksjon i operasjonsområdet }\end{array}$ \\
Indikatorens nevner: & Totalt antall kirurgiske inngrep på sykehuset \\
Nivå: & Landsnivå. Sykehusnivå \\
\hline
\end{tabular}




\subsubsection{Prevalensregistrering av helsetjeneste-assosierte infeksjoner}

\section{Indikatorens betydning}

Det er faglig enighet om at prevalensundersøkelser om helsetjenesteervervete infeksjoner bidrar til å øke oppmerksomheten på viktigheten av å forebygge denne type infeksjoner. Prevalensundersøkelser kan også bidra til å opprettholde fokuset på og kunnskapen om at helsetjenesteervervete infeksjoner og være til nytte ved prioritering av forebyggende arbeid.

Prevalensregistrering er en lite ressurskrevende metode. Men prevalensregistrering er ikke et godt mål på infeksjonsrisiko, blant annet fordi pasienter med sykehusinfeksjon ofte vil ha et forlenget sykehusopphold. Derfor vil de til enhver tid utgjøre en større relativ andel av de inneliggende pasientene enn av den relative andelen av pasienter som utskrives.

\section{Vitenskapelig belegg}

Infeksjoneregistrering er i en rekke publikasjoner vist å ha en uavhengig effekt på forekomsten av sykehusinfeksjoner (88,90,99,105-107). Fordelen med prevalensregistrering er at det er en rask og lite ressurskrevende metode for å anslå omfanget av sykehusinfeksjoner i et sykehus (108), men det er ikke en god metode for å estimere infeksjonsrisiko (109).

\section{Resultat}

Beskrivelse av dagens bruk av indikatoren og mulig fremtidig bruk.

Danmark: Statens Serum Institut organiserer nationale prævalensundersøgelser af nosokomielle infektioner to gange årligt. Ikke alle sygehuse deltager. Indikatoren ikke nærmere defineret endnu, men bliver en del af den danske kvalitetsmodel fra 2011.

Finland: Den første nasjonale prevalensregisterringen av helsetjenesteassosierte infeksjoner (HAI) hos voksne pasienter ble gjennomført ved 30 finske akuttsykehus i 2005. Basert på disse resultatene har morbiditet og mortalitet av HAI blitt anslått på nasjonalt nivå. I tillegg ble det utført 6 månedlige punktprevalensundersøkelser av HAI ved alle neonatale intensivenheter (NICU) i Finland mellom november 2008 og mai 2009 (110-112).

Fcrøyene: Der skønnes ikke at være grundlag for punktprævalensundersøgelser. 
Grønland: Prevalensregistrering af helsetjeneste-assosierte infektioner har ikke været gennemført systematisk i Grønland, men der er taget initiativ til at påbegynde registrering fra 2011.

Island: På Lanspitali Universitetssykehus gjørdes det punktprevalentsundersøkelse fire ganger årlig.

Norge: I Norge har det vært utført landsomfattende prevalensundersøkelser av sykehusinfeksjoner ved somatiske sykehus 2 ganger årlig siden 1999 og ved kommunale helseinstitusjoner/sykehjem siden 2002. Ved sykehus registreres urinveisinfeksjoner, nedre luftveisinfeksjoner, infeksjoner i blodbanen og infeksjoner i operasjonsområdet. Ved sykehjem registreres urinveisinfeksjoner, nedre luftveisinfeksjoner, hudinfeksjoner og infeksjoner i operasjonsområdet.

Sverige: En nationell satsning med målet att halvera prevalensen vårdrelaterade infektioner (VRI) startade år 2008. För att följa måluppfyllelsen genomförs punktprevalensmätningar två gånger årligen.

Drygt 20000 patienter i den somatiska slutenvården inrapporteras vid varje mättillfälle. Rapporteringen bygger på att en sjuksköterska och en läkare från varje avdelning gemensamt rapporterar samtliga patienter och anger hur många av dessa som bedöms vara drabbade av en VRI.

Bedömningen utgår från standardiserade instruktioner och ett protokoll. Andelen VRI har minskat vid varje mätning och minskningen innebär att motsvarande 42000 färre patienter årligen drabbas av en VRI under den senaste jämförelseperioden.

Tabell 10. Plan for hvordan indikatoren skal brukes i hvert land

\begin{tabular}{|c|c|c|c|}
\hline Land & $\begin{array}{l}\text { Plan för hur indikatorn ska } \\
\text { användas }\end{array}$ & $\begin{array}{l}\text { Organisation som kan samman- } \\
\text { ställa data }\end{array}$ & $\begin{array}{l}\text { När indikatorn } \\
\text { beräknas vara } \mathrm{i} \\
\text { bruk }\end{array}$ \\
\hline Danmark & Avdelings- og sykehusnivå & IKAS & Ikke planlagt \\
\hline Finland & Avdelings- og sykehusnivå & Institutet för hälsa och välfärd & 2011 \\
\hline Färöarna & Ikke relevant & & \\
\hline Grönland & Regions- og landssykehusnivå & Sundhedsledelsen & 2011 \\
\hline Island & Avdelings- og sykehusnivå & Landspitali & Pågår \\
\hline Norge & Avdelings- og sykehusnivå & Helsedirektoratet & Pågår \\
\hline Sverige & Avdelings- og sykehusnivå & $\begin{array}{l}\text { Sveriges Kommuner och } \\
\text { Landsting }\end{array}$ & Pågår \\
\hline
\end{tabular}




\section{Definisjoner og begrunnelse}

Prevalensregistrering er ikke en god metode for å måle risiko for HAI, og heller ikke til sammenligning mellom sykehus (se ovenfor). Men resultatene kan være et mål på hvilken belastning slike infeksjoner er for et sykehus, og hvor stor andel av sykehusets ressurser som går med til håndtering av pasienter med HAI.

Resultatene ved prevalensundersøkelser egner seg dårlig som en resultatindikator, men registrering vil i seg selv kunne bidra til forebygging av infeksjoner, både som følge av, at det bidrar til målrettede tiltak, men også pågrunn av den såkalte Hawthorneeffekten og vil på den måten kunne brukes som en prosessindikator.

\section{Tabell 11. Beskrivning af indikatoren}

\begin{tabular}{ll}
\hline Beskrivning av indikatoren: & Prevalensregistrering av alle HAI \\
Indikatorens teller: & $\begin{array}{l}\text { Kategorisk variabel (ja/nei): Gjennomføring av minst } 2 \text { prevalensre- } \\
\text { gisteringer av HAI i året }\end{array}$ \\
Indikatorens nevner: & Sykehus \\
Nivå: & Landsnivå. Sykehusnivå. \\
\hline
\end{tabular}

\subsubsection{Forbruk av hånddesinfeksjonsmidler}

\section{Indikatorens betydning}

Håndhygiene er et av de mest sentrale og effektive tiltak innen smittevern. Undersøkelser har vist at hånddesinfeksjon er mer effektivt enn tradisjonell håndvask med vann og såpe (113). Hånddesinfeksjon anbefales derfor som håndhygieneprosedyre der hendene ikke er tilsmusset. Til hånddesinfeksjon kan det brukes forskjellige virkestoffer. Uavhengig av virkestoff, skal hånddesinfeksjonsmiddelet tilfredsstille den europeiske standarden EN-1500.

\section{Vitenskapelig belegg}

Konklusjonene i litteraturen varierer når det gjelder sammenhengen mellom forbruksdata og forekomsten af sykehusinfeksjoner, men flere publikasjoner mener å påvise en sammenheng (113-116).

\section{Resultat}

Beskrivelse av dagens bruk av indikatoren og mulig fremtidig bruk. 
Danmark: Sporadiske opgørelser af forbruget af hånddesinfektionsmidler foretaget på udvalgte sygehus i Danmark i de senere år. Data forefindes formentlig på de fleste sygehuse. Indikatoren indgår i den danske kvalitestmodel fra 2011.

Finland: Basert på den ovenfor nevnte undersøkelsen fra 2009, var mediant forbruk av hånddesinfeksjonsmidler på sykehusnivå 47 liter per 1000 pasientdager (spredning mellom regioner 35-62) og i intensiv-avdelinger 120 liter (spredning mellom regioner 88-175).

Færøyene: Oplysninger om forbrug og forbrugsmønster kan fremskaffes.

Grønland: Data om forbrug af hånddesinfektionsmidler kan umiddelbart fremskaffes.

Norge: Noen norske sykehus registreres allerede slike data, og det vil være mulig å fremskaffe data for alle sykehus i Norge.

Sverige: Till del har denna indikator använts men den har successivt ersatts av mätningar av följsamhet till basala rutiner för handhygien. (se nedan). Data finns men för närvarande sker ingen systematisk sammanställning vare sig på sjukhus eller landsting/regionnivå.

Tabell 12. Plan for hvordan indikatoren skal brukes i hvert land

\begin{tabular}{llll}
\hline Land & $\begin{array}{l}\text { Plan för hur indikatorn ska } \\
\text { användas }\end{array}$ & $\begin{array}{l}\text { Organisation som kan sammanställa } \\
\text { data }\end{array}$ & $\begin{array}{l}\text { När indika- } \\
\text { torn beräk- } \\
\text { nas vara i } \\
\text { bruk }\end{array}$ \\
\hline Danmark & Avdelings- og sykehusnivå & IKAS & 2011 \\
Finland & Avdelings- og sykehusnivå & Institutet för hälsa och välfärd & 2011 \\
Färöarna & Avdelings- og sykehusnivå & Hygiejneorganisationen & 2011 \\
Grönland & Regions- og landssykehusnivå & Sundhedsledelsen & 2011 \\
Island & & & 2011 \\
Norge & Avdelings- og sykehusnivå & Helsedirektoratet & 2012 \\
Sverige & Avdelings- og sykehusnivå & Sveriges Kommuner och Landsting & 2 \\
\hline
\end{tabular}

\section{Definisjoner og begrunnelse}

Indikatorens teller kan uttrykkes som antall liter hånddesinfeksjonsmiddel som er forbrukt (innkjøpt) per tidsperiode, for eksempel per kalenderår.

Når det gjelder indikatorens nevner er det behov for en standardisering. Naturlig nok vil behovet for hånddesinfeksjon være svært avhengig av den kliniske aktiviteten ("case mix"). Det er publisert data på hvor ofte det er behov for å utføre håndhygiene i noen kliniske spesialiteter (114), men det er 
ikke utviklet et verktøy som kan benyttes for å justere for klinisk virksomhet. Behovet vil også influeres av driftsmessige forhold.

Denne indikatoren vil derfor ikke kunne benyttes for å sammenligne sykehus uten bedre underlag for hvordan man skal justere for slike variabler. Det er derfor nødvendig å etablere en standardisert kategorisering av klinisk aktivitet. Dette kan være antall innleggelser, antall liggedøgn, antall polikliniske konsultasjoner eller andre. Men forbruk av hånddesinfeksjonsmidler kan trolig anvendes på et mer overordnet nivå, slik som på landsnivå og amt/landsting/fylkesnivå. Den kan også benyttes til måling av utvikling og endringer over tid på sykehus- og avdelingsnivå.

\section{Tabell 13. Beskrivning af indikatoren}

\begin{tabular}{|c|c|}
\hline Beskrivning av indikatoren: & $\begin{array}{l}\text { Antall liter hånddesinfeksjon per år, målt i forhold til sykehusets } \\
\text { størrelse }\end{array}$ \\
\hline Indikatornes teller: & Antall liter forbrukt per år \\
\hline Indikatorens nevner & $\begin{array}{l}\text { Antall pasientdøgn, antall innleggelser, antall polikliniske konsulta- } \\
\text { sjoner }\end{array}$ \\
\hline Nivå: & Sykehusnivå. Landsnivå \\
\hline
\end{tabular}

Det finnes ikke data som gir holdepunkter for hva som er "riktig nivå" av forbruk av hånddesinfeksjon. Men det er mye dokumentasjon på at helsepersonell ikke desinfiserer hendene tilstrekkelig ofte. Denne indikatoren vil derfor først og fremst kunne brukes til intern sammenligning i det enkelte sykehus over tid, der man ut fra dagens situasjon på de fleste sykehus vil ha som målsetting at forbruket skal øke vesentlig.

\subsubsection{Etterlevelse av regler for håndhygiene}

Indikatorens betydning og vitenskapelig belegg

Håndhygiene er det viktigste enkelttiltak for å forebygge sykehusinfeksjoner.

Det er publisert et stort antall vitenskapelige artikler som viser at helsepersonell ikke utfører håndhygiene så ofte som de bør (113). Det er publisert studier som evaluerer metoder for registrering av etterlevelse av regler for håndhygiene, og som viser at det er mulig å gjennomføre standardisert og reproduserbar registrering av etterlevelse med et moderat forbruk av ressurser. 
Det er også noen holdepunkter for at økt etterlevelse gir resultater med redusert forekomst av sykehusinfeksjoner $(113,114)$.

\section{Resultat}

Beskrivelse av dagens bruk av indikatoren og mulig fremtidig bruk.

Danmark: Systematiske målinger af efterlevelse af håndhygiejneregler er udført på enkelte sygehuse i de senere år. Indgår som en indikator i den danske kvalitetsmodel fra 2011 og skal måles to gange årligt.

Finland: Det har ikke vært noen nasjonal kampanje, men det foregår mange regionale og lokale aktiviteter om håndhygiene, som får økonomisk støtte fra regjeringen. Dette inkluderer trening av helsepersonell, en video om håndhygiene laget av Finnish Society for Hospital Infection Control og et elæringskurs om infeksjonsforebygging (http://www.sshy.fi/). I tillegg har det vært gjennomført mange regionale kampanjer med fokus på håndhygiene.

Fœrøyene: Sytematiseret undervisning finder sted på kursus- og afsnitsniveau. Undersøgelse af compliance og holdniger til håndhygiejne bliver gennemført i 2011.

Grønland: Der gennemføres jævnligt undervisning i hygiejniske retningslinjer, men systematisk måling af håndhygiejniske forholdsregler foretages endnu ikke.

Norge: I løpet av 2010 vil det foregå opplæring av smittevernpersonell i bruk av WHOs observasjonsmetode for compliance med håndhygiene. Rapportering av compliance kan bli en del av den planlagte nasjonale pasientsikkerhetskampanjen.

Sverige: Mätning av följsamheten till basala rutiner för handhygien och till klädregler ingår i ett nationellt projektet. (Se www.skl.se/projekt/vriss) Följsamheten till rutiner och reglerna mäts hos minst tio personer ur varje personalkategori på den enskilda vårdenheten varje månad.

Flera hundra team på olika kliniker i Sverige arbetar enligt denna metod. Många sjukhus mäter följsamhet till basala hygienrutiner och klädregler kontinuerligt. Under 2010 planeras nationella punktprevalensmätningar av följsamhet till basala hygienrutiner och klädregler. Protokollen för dessa mätningar bygger på den metod som utarbetades i VRISS projektet.

\section{Definisjoner og begrunnelse}

Siden manglende etterlevelse av håndhygiene er et problem, kan måling av etterlevelse være et virkemiddel for forbedring (114). 
Teller: Etterlevelse av håndhygiene i henhold til WHOs kriterier (117).

Nevner: Antall anledninger (opportunities) for håndhygiene. Både teller og nevner rapporteres. Metoden vil spesielt være nyttig for å følge utviklingen lokalt og for lokal sammenligning og forbedringsarbeid.

\section{6 Överförskrivning av läkemedel hos äldre}

\subsubsection{Andel äldre som har förskrivits 10 eller fler läkemedel}

Indikatorns betydelse

Under de senaste decennierna har äldres läkemedelsanvändning ökat markant, främst till följd av nya möjligheter att behandla olika sjukdomar och tillstånd som är vanliga hos den äldre befolkningen $(15,118)$. En del av bakgrunden till den ökade användningen är emellertid oklar (119). Den ökade användningen av läkemedel innebär nya risker för olika typer av läkemedelsproblem. Antal använda läkemedel har utpekats som den mest avgörande riskfaktorn för läkemedelsbiverkningar och läkemedelsinteraktioner. Samtidig användning av många läkemedel (polyfarmaci) anses också öka sannolikheten för olämplig läkemedelsanvändning, liksom risken för att ordinationerna inte följs (120).

En vanlig definition av polyfarmaci är "användning av fem eller fler läkemedel”. Användning av tio eller fler läkemedel har i vissa studier av äldre tillämpats som mått på extrem polyfarmaci (119). Samtidig användning av tio eller fler preparat hos en patient bör därför betraktas som en signal om, att det kan finnas risker med läkemedelsbehandlingen. På samma sätt indikerar en hög förekomst av denna indikator på gruppnivå, att det med stor sannolikhet föreligger brister i läkemedelsbehandlingen.

\section{Vetenskapligt belägg}

Samtidig användning av många läkemedel har i flera studier visat sig utgöra en oberoende riskfaktor för läkemedelsbiverkningar både bland äldre på institutioner och äldre i öppen vård $(121,122)$. Risken för undvikbara läkemedelsbiverkningar har visat sig öka med antal medicineringar (122,123). Den ökade risken för läkemedelsbiverkningar bland äldre med funktionsnedsättningar har förknippats med mängden använda läkemedel (123). 
Generellt har polyfarmaci visats öka risken för återinläggning på sjukhus till följd av läkemedelsreaktioner (16). Den har också satts i samband med ökad risk för fallskador bland äldre (124). Vård och behandling av läkemedelsbiverkningar bland äldre medför avsevärda extra kostnader för sjukvård och samhälle $(125,126)$.

\subsubsection{Andel äldre som har förskrivits tre eller fler psykofarmaka}

Indikatorns betydelse

Med psykofarmaka förstås antidepressiva och lugnande läkemedel, sömnmedel samt antipsykosmedel (neuroleptika). Användningen av psykofarmaka bland äldre har under många år visat en uppåtgående trend och samtidig behandling med tre eller fler psykofarmaka, regelbundet eller vid behov, har använts som indikator på polyfarmaci $(118,127)$.

\section{Vetenskapligt belägg}

Samtidig behandling med många psykofarmaka innebär en ökad risk för biverkningar och läkemedelsinteraktioner och kan vara ett tecken på brister i behandlingen av psykiatriska tillstånd $(118,120,128)$. Även om behandling med flera läkemedel kan vara motiverad hos vissa patientgrupper, tyder studier på, att polyfarmaci utan vetenskaplig grund är vanligt förekommande inom äldrevård och psykiatri och att risken för biverkningar till följd av denna typ av polyfarmaci är påtaglig, särskilt bland äldre patienter (129-131).

\subsubsection{Andel äldre med risk för allvarliga läkemedelsinteraktioner}

\section{Potentiell indikator}

Indikatorns betydelse och vetenskapligt belägg

SFINX (Swedish, Finnish, Interaction X-referencing) är en databas för läkemedelsinteraktioner. SFINX innehåller cirka 8500 interaktionspar (2008). För varje interaktion finns information om vilka risker den kan medföra och rekommendationer för hur dessa kan undvikas. SFINX innehåller i första hand sådana farmakokinetiska interaktioner som finns publicerade i den vetenskapliga litteraturen eller som refereras till i läkemedlens produktbeskrivningar. 
Interaktionsparen baseras på substansnamn och beredningsform. Interaktionerna klassificeras efter klinisk relevans (A-D) och dokumentationsnivå (0-4). Detta gör det möjligt att välja den nivå som man aktivt vill varna för i ett journalsystem (132).

I Finland: används SFINX både vid ordination och på apotek. I Sverige används SFINX vid ordination men användningen är ännu inte utbredd. Om användningen av databasen utvidgas till andra nordiska länder, kan indikatorn senare användas på samnordisk basis.

\section{Resultat}

Nedan redovisas hur de uppgifter som behövs för beräkning av de tre polyfarmaciindikatorerna kan samlas in.

Danmark: Det vil formentlig kræve udvidet adgang til data fra Lægemiddelstyrelsen, hvilket skal forhandles med respektive partnere.

Finland: De data som behövs för indikatorn finns i Folkpensionsanstaltens register över läkemedel och ersättningsrättigheter, men har publicerats endast i forskningsrapporter. Folkpensionsanstalten och Institutet för hälsa och välfärd kan samarbeta och börja publicera data i nationella rapporter över patientsäkerhet.

Färöarna: En landsdækkende elektronisk patientjournal, som blandt andet indeholder et lægemiddelregister, er ved at være indført.

Jounalen omfatter både de praktiserende læger og sygehusene, og ventes at være færdig implementeret 1 . kvartal 2011. Systemet giver, ved ordination af lægemidler, advarsler om interaktioner, amning og graviditet og dobbeltordinationer.

På Færøerne er der ligeledes et landsdækkende register over lægemiddelforbrug i primær- og sekundærsektoren. Vedrørende primærsektoren, så er lægemiddelforbruget registreret ned på individuelt niveau, dvs. det er ikke noget problem på nuværende tidspunkt at registrere personer, der bruger mere end 10 forskellige slags medicin.

Grönland: Al medicin på recept udleveres fra sygehusenes apoteker, og der er indført et landsdækkende elektronisk patientjournalsystem med lægemiddelregister. Implementeringen af systemet har givet problemer, idet medicinen endnu registreres meget forskelligt i distrikterne. Der arbejdes på at sikre ensartet registrering med henblik på at skabe overblik over behandlingen af den enkelte patient, samt at kunne trække valide oplysninger fra systemet. Data forventes at kunne leveres fra 2011. 
Island: Island har ett landsomfattande läkemedelsregister sedan 2003. Det innehåller individbaserad information om alla föreskrivna läkemedel utanför sjukhus och utanför institutioner. ATC nummer och nordiskt varunummer ingår, samt förskrivningsdatum, uthämtningsdatum och uppgift om föreskrivande läkare och dennes specialitet. Information om läkemedelsanvändning på vårdhem går att hämta genom RAI systemet.

Norge: Norge har et elektronisk reseptregister der data om alle resepter lagres. Det inkluderer ikke legemidler gitt til pasienter mens de er på sykehus/sykehjem/aldershjem. Det er mest sannsynlig mulig å ta ut nødvendig informasjon fra dette registeret. Mest sannsynlig kan data leveres fom 2011.

Sverige: Kvaliteten i äldres läkemedelsanvändning har sedan år 2006 analyserats med hjälp av nationella indikatorer för äldres läkemedelsterapi (119). Indikatorerna är baserade på data från det nationella registret över förskrivna läkemedel. Bland annat har ovan nämnda indikatorer sedan dess regelbundet redovisats i s.k. "öppna jämförelser” av hälso- och sjukvårdens kvalitet. Sverige tillämpar gränsen 80 år (65-79 och $\geq 80$ år) i "öppna jämförelser”.

Hur polyfarmaciindikatorerna kan komma till användning i respektive land framgår av tabell 14.

Tabell 14. Hur indikatorerna kan införas i de nordiska länderna

\begin{tabular}{|c|c|c|c|}
\hline \multirow[t]{2}{*}{ Land } & \multicolumn{3}{|c|}{$\begin{array}{l}\text { Indikatorernas namn: Andel (\%) äldre som använder } 10 \text { eller fler läkemedel och andel äldre } \\
\text { som använder tre eller fler psykofarmaka (i åldersgrupperna } 65-74 \text { år respektive }>75 \text { år) }\end{array}$} \\
\hline & $\begin{array}{l}\text { Plan för hur indikatorn ska } \\
\text { komma till användning }\end{array}$ & $\begin{array}{l}\text { Organisation som kan sam- } \\
\text { manställa data }\end{array}$ & $\begin{array}{l}\text { När indikatorn be } \\
\text { räknas vara } \mathrm{i} \text { bruk }\end{array}$ \\
\hline Danmark & $\begin{array}{l}\text { Forudsætter adgang til } \\
\text { nationalt lægemiddelregister }\end{array}$ & $\begin{array}{l}\text { Sundhedsstyrelsen. Det } \\
\text { Nationale Indikator Projekt }\end{array}$ & 2011 \\
\hline Finland & $\begin{array}{l}\text { Folkpensionsanstalten } \\
\text { Registren över läkemedel } \\
\text { och ersättningsrättigheter }\end{array}$ & $\begin{array}{l}\text { Folkpensionsanstalten och } \\
\text { Institutet för hälsa och } \\
\text { välfärd }\end{array}$ & 2011 \\
\hline Färöarna & $\begin{array}{l}\text { Kan trækkes fra landsdæk- } \\
\text { kende Apoteker system }\end{array}$ & $\begin{array}{l}\text { Sundhedsministeri- } \\
\text { et/Apoteksvæsenet }\end{array}$ & Ikke planlagt \\
\hline Grönland & $\begin{array}{l}\text { Kan trækkes fra landsdæk- } \\
\text { kende elektronisk patient- } \\
\text { journal }\end{array}$ & $\begin{array}{l}\text { Sundhedsledelsen } \\
\text { Landslægeembedet }\end{array}$ & 2011 \\
\hline Island & $\begin{array}{l}\text { Kan trækkes fra landsdæk- } \\
\text { kende Läkemedelsregister }\end{array}$ & $\begin{array}{l}\text { Medisinalstyrelsen (Land- } \\
\text { læknisembættið) }\end{array}$ & 2011 \\
\hline Norge & $\begin{array}{l}\text { Norge har et nasjonalt re- } \\
\text { septregister. }\end{array}$ & $\begin{array}{l}\text { Helsedirektoratet/ } \\
\text { Kunnskapssenteret }\end{array}$ & 2012 \\
\hline Sverige & Nationell indikator för God & Socialstyrelsen & Sedan 2006 \\
\hline
\end{tabular}


Definition och överväganden

Läkemedelsregistren omfattar inte preparat ordinerade i sluten vård, dispenserade från läkemedelsförråd, eller köpta utan recept. Registren omfattar endast från apoteket uthämtade läkemedel. Metoden att uppskatta aktuell läkemedelsförskrivning innebär en viss osäkerhet, främst genom tolkningen av doseringsangivelser som i dag föreligger i fri text. Läkemedelsförskrivning återspeglar inte alltid den faktiska läkemedelsanvändningen, eftersom brister i följsamhet till ordination ofta föreligger, i synnerhet vid en omfattande läkemedelsanvändning.

Beskrivning av indikatorerna

Andel (\%) äldre som har förskrivits 10 eller fler läkemedel.

Täljare: Antal personer i åldern 65-74 år, respektive > 75 år som har minst 10 förskrivna läkemedel

Andel äldre som har förskrivits tre eller fler psykofarmaka

Täljare: antal personer i åldern 65-74 år, respektive > 75 år som har minst tre förskrivna psykofarmaka

Andel äldre med risk för allvarliga läkemedelsinteraktioner

Täljare: antal personer i åldern 65-74 år, respektive > 75 år som har minst en kombination av läkemedel som kan leda till en läkemedelsinteraktion av klass D.

Nämnaren i de tre indikatorerna är:

Antal personer i åldern 65-74 år respektive > 75 år.

Resultaten för de tre indikatorerna redovisas som procentandelar $i$ åldersgrupperna 65-74 år, respektive 75 år och äldre.

\section{Referencer}

1. Schiøler T, Lipczak H, Pedersen BL, et al. Forekomsten av utilsigtede hændelser på sygehus. En retrospektiv gen- namgang af journaler. Ugeskr. Læger.2001;163:5370-8.

2. Soop M, Fryksmark U, Köster M, et al. The incidence of adverse events in 
Swedish hospitals: a retrospective medical record review study. Int $\mathrm{J}$ Qual Health Care, 2009 21(4):285-91.

3. Evidence Report/Technology Assessment Number 43: Making Health Care Safer: A Critical Analysis of Patient Safety Practices. Rockville, Md: US Dept of Health and Human Services, Agency for Healthcare Research and Quality; 2001. AHRQ publication 01E058.

4. Resar RK, Rozich JD, Simmonds T, et al. Methodology and rationale for the measurement of harm with trigger tools. Qual Saf Health Care 2003; 12:194-200.

5. Wolff A M, Bourke J, Campell I A, et al. Detecting and reducing adverse events: outcomes of the Wimmera clinical risk management program. Med J Aust 2001; 174: 621-25.

6. Nilsson L, Juhlin C, Krook H, et al. Strukturerad journalgranskning kan öka patientsäkerheten. Läkartidningen 2009; 106:2125-2128.

7. Donnelly LF, Dickerson JM, Goodfreind MA, et al. Improving patient safety: effects of a safety program on performance and culture in a department of radiology. Am J Roentgenol. 2009; 193(1):165-71.

8. Singer S, Lin S, Falwell A, et al. Relationship of safety climate and safety performance in hospitals. Health Serv Res. 2009; 44(2):399-421.

9. Jarman B, Bottle A, Aylin P et al. Monitoring changes in hospital standardised mortality ratios. BMJ 2005 Feb 12; 330(7487):329.

10. Köster M, Jürgensen U, Spetz CL, et al. Standardiserad sjukhusmortalitet som kvalitetsmått i hälso- och sjukvård. Läkartidningen 2008; 105:13911397.

11. Mihrshahi S, Brand C, Ibrahim JE, et al. Literature review: Validity of the indicator "death in low mortality diag- nosis related groups" for measureing patient safety and health care quality in hospitals. Intern Med J 2010; 40(4):250-7.

12. Burke J. Infection Control. A Problem for Patient Safety. N. Engl. J Med. 2003; 348(7):651-6.

13. Emori TE, Gaynes RP. An overview of nosocomial infections, including the role of the microbiology laboratory. Clin Microbiol Rev 1993; 6:428-42.

14. Harbarth S, Sax H, Gastmeier P. The preventable proportion of nosocomial infections: an overview of published reports. J Hosp Infect 2003; 54:258266.

15. Linjakumpu T, Hartikainen S, Klaukka T, et al. Use of medications and polypharmacy are increasing among elderly. J Clin Epidemiol 2002; 55:809-17

16. Ruiz B, Garcia M, Aguirre, et al. Factors predicting hospital readmissions related to adverse drug reactions. Eur J Cli Pharmacol 2008; 64:715-22.

17. Saskia E. Drösler, Niek S. Klazinga, et al. Application of patient safety indicators internationally: a pilot study among seven countries Int J Qual Health Care, August 2009; 21:272278.

18. Ren vård är säkrare vård II, 2008. Sveriges Kommuner och Landsting 19. Sari A, Sheldon T, Cracknell A et al. Sensitivity of routine system for reporting patient safety incidents in a NHS hospital: retrospective patient case note review. BMJ 2007; 334:7982.

20. Olsen S, Neale G, Schwab K et al. Hospital staff should use more than one method to detect adverse events and potential adverse events: incident reporting, pharmacist surveillance and local real-time record review may all have a place. Qual Saf Health Care 2007; 1640-44. 
21. Kohn LT, Corrigan JM, Donaldson MS. To err is human: building a safer health system. Washington, DC: National Academy Press, 2000.

22. Baker GR, Norton PG, Flintoft V et al. The Canadian Adverse Events Study: the incidence of adverse events among hospital patients in Canada. CMAJ 2004; 170: 1678-86.

23. Vincent C, Neale G, Woloshynowych M. Adverse events in British hospitals: preliminary retrospective record review. BMJ 2001; 322:517-19.

24. Resar RK, Rozich JD, Simmonds T et al. A Trigger Tool to Identify Adverse Events in the Intensive Care Unit. Jt Comm J Qual Saf 2006; 32: 585-90.

25. Griffin FA, Resar RK. IHI Global Trigger Tool for measuring adverse events. IHI Innovation Series white paper. (Second edition) Cambridge, Massachusetts: 625 Institute for Healthcare Improvement; 2009.

26. Unbeck M, Muren O, Lillkrona U. Identification of adverse events at an orthopaedic department in Sweden. Acta Orthop 2008; 79: 396-403.

27. Agency for Healthcare Research and Quality. Triggers and Targeted Injury Detection Systems (TIDS) Expert Panel Meeting: Conference Summary. Rockville, MD. AHRQ Pub. No. 090003. Feb. 2009.

28. Madsen MD. Improving Patient Safety: Safety Culture \& Patient Safety Ethics. http://www.risoe.dk/rispubl/SYS/syspdf/ris-phd-25.pdf. Denmark: Roskilde University; 2006.

29. Flin R. Measuring safety culture in healhtcare: A case for accurate diagnosis. Safety Science 2007 Apr; 45:653-67.

30. Pronovost P, Holzmueller CG, Needham DM, Sexton JB, Miller M, Berenholtz S, et al. How will we know patients are safer? An organization- wide approach to measuring and improving safety. Crit Care Med 2006 May 17.

31. Kristensen S, Mainz J, Bartels PD. Måling af patientsikkerhed - hvorfor og hvordan? Ugeskr Laeger 2009 May 11; 171(20):1674-7.

32 Thomas EJ, Sexton JB, Neilands TB, Frankel A, Helmreich RL. The effect of executive walk rounds on nurse safety climate attitudes: a randomized trial of clinical units. BMC Health Serv Res 2005 Apr 11; 5(1):28.

33. Frankel A, Grillo SP, Pittman M, Thomas EJ, Horowitz L, Page M, et al. Revealing and resolving patient safety defects: the impact of leadership WalkRounds on frontline caregiver assessments of patient safety. Health Serv Res 2008 Dec;43(6):2050-66.

34. Jones KJ, et al. The AHRQ Hospital Survey on Patient Safety Culture: A Tool to Plan and Evaluate Patient Safety Programs. www ahrq gov 2008;1-22.

35. McCulloch P, Mishra A, Handa A, Dale T, Hirst G, Catchpole K. The effects of aviationstyle nontechnical skills training on technical performance and outcome in the operating theatre. Qual Saf Health Care 2009 Apr; 18(2):109-15.

36. Sax HC, Browne P, Mayewski RJ, Panzer RJ, Hittner KC, Burke RL, et al. Can aviationbased team training elicit sustainable behavioral change? Arch Surg 2009 Dec; 144(12):1133-7.

37. Weaver SJ, Rosen MA, Diaz Granados D, Lazzara EH, Lyons R, Salas E, et al. Does teamwork improve performance in the operating room? A multilevel evaluation. Jt Comm J Qual Patient Saf 2010 Mar; 36(3):133-42.

38. Armstrong K, Laschinger $\mathrm{H}$, Wong C. Workplace empowerment and magnet hospital characteristics as predic- 
tors of patient safety climate. J Nurs Care Qual 2009 Jan; 24(1):55-62.

39. Hartmann CW, Meterko M, Rosen AK, Shibei Z, Shokeen P, Singer S, et al. Relationship of hospital organizational culture to patient safety climate in the Veterans Health Administration. Med Care Res Rev 2009 Jun; 66(3):320-38.

40. Vogus TJ, Sutcliffe KM. The Safety Organizing Scale: development and validation of a behavioral measure of safety culture in hospital nursing units. Med Care 2007 Jan; 45(1):46-54.

41. Naveh E K-NTSZ. Treatment Errors in Healthcare: A Safety Climate Approach. Management Science 2005 Jun 1; 51(6):948-60.

42. DeFontes J, Surbida S. PreProject operative Safety Briefing. The Permanente Journal 2004; 8(Spring):21-7.

43. Zohar D, Livne Y, Tenne-Gazit O, Admi H, Donchin Y. Healthcare climate: a framework for measuring and improving patient safety. Crit Care Med 2007 May;35(5):1312-7.

44. Vogus TJ, Sutcliffe KM. The impact of safety organizing, trusted leadership, and care pathways on reported medication errors in hospital nursing units. Med Care 2007 Oct; 45(10):997-1002.

45. Snijders C, Kollen BJ, van Lingen RA, Fetter WP, Molendijk H. Which aspects of safety culture predict incident reporting behavior in neonatal intensive care units? A multilevel analysis. Crit Care Med 2009 Jan; 37(1):61-7.

46. Singer S, Falwell A, Lin SH, Rathgeb T, Baker L. Relationship between hospital saefty climate and outcomes. 2006.

48. Redley B, Botti M, Johnstone M, Bucknall T, Cameron P, Evans S, et al. Safety culture and team climate in Post Anaesthetic Care Units (PACU): im- pact on handover safety, http://www.isqua.org/Uploads/Confere nce/Abstracts/Microsoft_PowerPoint__B23_530_Redley_et_al_Team_culture.pdf. . 2010.

49. Pronovost $\mathrm{P}$, et al. Implementing and Validating a Comprehensive UnitBased Safety Program. J Patient Saf 2010;1(1):33-40.

50. Pettker CM, Thung SF, Norwitz ER, Buhimschi CS, Raab CA, Copel JA, et al. Impact of a comprehensive patient safety strategy on obstetric adverse events. Am J Obstet Gynecol 2009 May; 200(5):492-8.

51. Katz-Navon T, Naveh E, Stern Z. Active learning: when is more better? The case of resident physicians' medical errors. J Appl Psychol 2009 Sep; 94(5):1200-9.

52. Hofmann DA, Mark B. An investigation of the relationship between safety climate and medication errors as well as other nurse and patient outcomes. Personnel Psychology 2006; 59(4):847-69.

53. Pronovost PJ, Berenholtz SM, Goeschel CA, Needham DM, Sexton JB, Thompson DA, et al. Creating high reliability in health care organizations. Health Serv Res 2006 Aug; 41(4 Pt 2):1599-617.

54. Pronovost PJ, Berenholtz SM, Goeschel C, Thom I, Watson SR, Holzmueller CG, et al. Improving patient safety in intensive care units in Michigan. J Crit Care 2008 Jun; 23(2):207-21.

55. Pronovost PJ, Goeschel CA, Marsteller JA, Sexton JB, Pham JC, Berenholtz SM. Framework for patient safety research and improvement. Circulation 2009 Jan 20; 119(2):330-7.

56. Hudson D, Sexton B, Thomas E, Berenholtz S. A Safety Culture Primer for the Critical Care Clinician - The Role of Culture in Patient Safety and 
Quality Improvement. Contemporaty Critical Care 2009 Oct; 7(5):1-12.

57. Watson SR, George C, Martin M, Bogan B, Goeschel C, Pronovost PJ. Preventing central line-associated bloodstream infections and improving safety culture: a statewide experience. Jt Comm J Qual Patient Saf 2009 Dec; 35(12):593-7.

58. Huang DT, Clermont G, Kong L, Weissfeld LA, Sexton JB, Rowan KM, et al. Intensive care unit safety culture and outcomes: a US multicenter study. Int J Qual Health Care 2010 Apr 9.

59. Rosen AK, Singer S, Zhao S, Shokeen P, Meterko M, Gaba D. Hospital Safety Climate and Safety Outcomes: Is There a Relationship in the VA? Med Care Res Rev 2010 Feb 5.

60. Davenport DL, Henderson WG, Mosca CL, Khuri SF, Mentzer RM, Jr. Risk-adjusted morbidity in teaching hospitals correlates with reported levels of communication and collaboration on surgical teams but not with scale measures of teamwork climate, safety climate, or working conditions. J Am Coll Surg 2007 Dec; 205(6):778-84.

61. Gaba DM, Singer SJ, Rosen AK. Safety culture: is the "unit" the right "unit of analysis”? Crit Care Med 2007 Jan; 35(1):314-6.

62. Smits M, Wagner C, Spreeuwenberg P, Wal Gvd, Groenewegen PP. Measuring patient safety culture: an assessment of the clustering of responses at unit level and hospital level. Qual Saf Health Care 2009 Aug; 18(4): 297302.

63. Deilkas ET, Hofoss D. Patient safety culture lives in departments and wards: Multilevel partitioning of variance in patient safety culture. BMC Health Serv Res 2010 Mar 31; 1-17.

64. Carney BT, Mills PD, Bagian JP, Weeks WB. Sex differences in operating room care giver perceptions of pa- tient safety: a pilot study from the Veterans Health Administration Medical Team Training Program. Qual Saf Health Care 2010 Apr; 19(2):128-31. 65 Singer SJ, Falwell A, Gaba DM, Baker LC. Patient safety climate in US hospitals: variation by management level. Med Care 2008 Nov; 46(11):1149-56.

66 Thomas EJ, Sexton JB, Helmreich RL. Discrepant attitudes about teamwork among critical care nurses and physicians. Crit Care Med 2003 Mar; 31(3):956-9.

67. Pronovost P, Sexton B. Assessing safety culture: guidelines and recommendations. Qual Saf Health Care 2005 Aug; 14(4):231-3.

68. Sexton JB, Paine LA, Manfuso J, Holzmueller CG, Martinez EA, Moore $D$, et al. A check-up for safety culture in "my patient care area”. Jt Comm J Qual Patient Saf 2007 Nov; 33(11):699-703, 645.

69. Kristensen S, Bartels PD. Use of Patient Safety Culture Instruments and Recommendations. 1 ed. European Society for Quality in Healthcare, Office for Quality Indicators; 10 A.D.

70. Kristensen S, Bartels PD. Patient Safety Culture Instruments used in Member States. 1 ed. European Society for Quality in Healthcare, Office for Quality Indicators; 2010.

71. Scottish Audit of Surgical Mortality - Structure and Methods http://www.sasm.org.uk/About/Structu reandMethods.htm\#cas. Scotland: ISD Scotland Publications; 2009.

72. Deaths in Acute Hospitals: Caring to the End? A review of the care of patients who died in hospital within four days of admission. London: The National Confidential Enquiry into Patient Outcome and Death (NCEPOD); 2009. 
73. Iezzoni LI. 100 apples divided by 15 red herrings: a cautionary tale from the mid-19th century on comparing hospital mortality rates. Ann Intern Med 1996 Jun 15;124(12):1079-85.

74. Nilsson L, Juhlin C, Krook H, Sjödahl R, Rutberg H. Strukturerad journalgranskning kan öka patientsäkerheten. Läkartidningen 2010;106(35):2125-8.

75. Pedersen BL, Mogensen T, et al. Patientsikkerhed - fra sanktion til læring. København: Munksgaard; 2003.

76. Behal R, Finn J. Understanding and improving inpatient mortality in academic medical centers. Acad Med 2009;84(12):1657-62.

77. Ben-Tovim D, Woodman D, Harrison J, Pointer S, Hakendorf P, Henley G. Measuring and reporting mortality in hospital patients. Canberra: The Australien Institute of Health and Welfare (AIHW); 2009.

78. Christensen S, Jacobsen J, Bartels P, Norgaard M. Hospital standardised mortality ratios based on data from administrative registries. A pilot project. Ugeskr Laeger 2007; 169(34):2767-72.

79. Death in low-mortality DRGs: inhospital deaths per 1,000 discharges. http://www.qualitymeasures.ahrq.gov/s ummary/summary.aspx?doc_id=12715: The National Quality Measures Clearinghouse $^{\mathrm{TM}}$ (NQMC); 2008.

80. Heijink R, Koolman X, Pieter D, van d, V, Jarman B, Westert G. Measuring and explaining mortality in Dutch hospitals; the hospital standardized mortality rate between 2003 and 2005 . BMC Health Serv Res 2008; 8:73.

81. Mohammed MA, Deeks JJ, Girling A, Rudge G, Carmalt M, Stevens AJ, et al. Evidence of methodological bias in hospital standardised mortality ratios: retrospective database study of
English hospitals. BMJ 2009; 338:b780.

82. Penfold RB, Dean S, Flemons W, Moffatt M. Do hospital standardized mortality ratios measure patient safety? HSMRs in the Winnipeg Regional Health Authority. Healthc Pap 2008; 8(4):8-24.

83. Jarman B. In defence of the hospital standardized mortality ratio. Healthc Pap 2008; 8(4):37-42.

84. McKinley J, Gibson D, Ardal S. Hospital Standardized Mortality Ratio: The Way Forward in Ontario. Healthc Pap 2008 Jul 15;8(4):43-9.

85. Lilford R, Pronovost P. Using Hospital Mortality Rates to Judge Hospital Performance: A bad idea that just won't go away. BMJ 2010; 340: 955-7

86. Gardner AMN, Stamp M, Bowgren JA, Moore B. The infection control sister. A new member of the infection control team in general hospitals. Lancet 1962;2:710-711.

87. Eickhoff TC, Brachman PS, Bennett $\mathrm{JV}$, et al. Surveillance of nosocomial infections in community hospitals. I: Surveillance metods, effectiveness, and initial results. J Infect Dis 1969; 120:305-17

88. Haley RW, Culver DH, White JW, et al. The efficacy of infection surveillance and control programs in preventing nosocomial infections in US hospitals. Am J Epidemiol 1985; 121:182205.

89 Haley RW, Morgan WM, Culver DH, et al. Update on the SENIC project. Hospital infection control: Recent progress and opportunities under prospective payment. Am J Epidemiol 1985; 13:97-108.

90. Haley RW. Managing hospital infection control for costeffectiveness. American Hospital Publishing Inc., Chicago, 1986. 
91. O'Boyle C, Jackson M, Henly SJ. Staffing requirements for infection control programs in US health care facilities: Delphi project. Am J Infect Control 2002; 30:321-33.

92. Stone P, Dick A, Pogorzelska M, et al. Staffing and structure of infection prevention and control programs. Am J Infect control 2009; 37:351-7.

93. Health Canada, Nosocomial and Occupational Infections Section. Development of a resource model for infection prevention and control programs in acute, long term, and home care settings: Conference proceedings of the infection Prevention and Control alliance. Am J Infect Control 2004; 32:2-6.

94. van den Broek PJ, Kluytmans JAJW, Ummels LC, Voss A., VandenbrouckeGrauls CMJE. How many infection control staff do we need in hospitals? J Hosp Infect 2007; 65:108-111.

95. Lyytikäinen O, Jalkanen M, Ratia M, Héllsten S, Kujala P, Rantala A, Ruutu P. Sairaalainfektioiden torjunta Suomen sairaaloissa. Suomen Lääkärilehti 2003; 24:2623-6.

96. Kärki T, Heliö-Hietaniemi I, Möttönen T, Ruutu P, Lyytikäinen O. Hoitoon liittyvien infektioiden torjunta Suomen sairaloissa 2008. Suomen Lääkärilehti (painossa).

97. Siegel JD, Rhinehart E, Jackson M, Chiarel o L for the Health care Infection Control Practice Advisory Committee. 2007 guideline for isolation precautions: prevention of transmission of infectious agenst ih health care settings. Am J Infect Control 2007;35:S65-164.

98. DH Estates and Facilities Division. Health building note 04-01: adult inpatient facilities. London: Stationery Office; 2008.

99. Mears A, White A, Cookson B et al. Healthcare-associated infection in acute hospitals: which interventions are effective? J Hosp infect 2009; 71:307-313.

100. Guideline for Design and Construction of Health Care Facilities. The American Institute of Architects. Washington, Dc 2006. ISBN: 1-57165013-X

101. Kärki T, Heliö-Hietaniemi I, Möttönen T, Ruutu P, Lyytikäinen O. Hoitoon liittyvien infektioiden torjunta Suomen sairaloissa 2008. Suomen Lääkärilehti (painossa)

102. Lyytikäinen O, Kela E, Kujala P. Eristystilat Suomen sairaaloissa. Sairaalahygienialehti 2003;4:179-80.

103. Kjellgren K, Norberg B, Fryklund B, Burman LG. Registrering av kirurgiska infektioner kan "spara” mångmiljonbelopp i vården. Läkartidningen 1985;82(50):4428, 4430-1.

104. Huotari K, Lyytikäinen O. Impact of postdischarge surveillance on the rate of surgical site infection after orthopaedic surgery. Infect Control Hosp Epidemiol 2006; 27:1324-1329.

105. Wenzel RP, Osterman CA, Huntling KJ, et al. Hospital aquired infections. I. Surveillance in a university hospital Am J Epidemiol 1976; 103:251-260.

106. Haley RW. Surveillance by Objective: a new priority-directed approach to the control of nosocomial infections. Am J Infect Control 1985; 13:78-89.

107. National Nosocomial Infections Surveillance System. Nosocomial infection rates for interhospital comparison. Infect Control Hospital Epidemiol 1991; 12:609-621.

108. French GL, Cheng AF, Wong SL, et al. Repeated prevalence surveys for itoring effectiveness of hospital infection control. Lancet 1989; 2:1021-1023.

109. Rhame FS, Suddert WD. Incidence and prevalence as used in the analysis 
of the occurrence of nosocomial infections. Am J Epidemiol 1981; 113:1-11. 110. Lyytikäinen O, Kanerva M, Agthe N, Möttönen T, Ruutu P and the Finnish Prevalence Survey Study Group. Health careassociated infections in Finnish acute care hospitals: a national prevalence survey, 2005. J Hosp Infect 2008; 69:288-94.

111. Kanerva M, Ollgren J, Virtanen MJ, Lyytikäinen $\mathrm{O}$, on behalf of the prevalence survey study group. Estimating the annual burden of healthcareassociated infections in Finnish adult acute care hospitals. Am J Infect Control 2008; 37:227-30.

112. Sarvikivi E, Lyytikäinen $O$ and the NICU Prevalence Study Group. Repeated prevalence surveys of healthcare-associated infections in Finnish neonatal intensive care units. J Hosp Infect (in press).

113. WHO guidelines on hand hygiene in health care. ISBN 978924159790. World Health Organization 2009.

114. Pittet D. Compliance with hand disinfection and its impact on hospitalacquired infections J Hosp Infection 2001 (Supplement A):48;S40-46.

115. Herud T, Nilsen RM, Svendheim K, Harthug S. Association between use of hand hygiene products and rates of health care-associated infections in a large university hospital in Norway. Am J Infect Control 2009; 37:311-7.

116. Verjat-Trannoy D, Millani K, Nguyen S, Sitbon M, Landriu D, Astagneau P. Compliance to alcoholbased handrub and relationship with hydro-alcoholic solution consumption indicator: a multicenter assessment study in Northern France. Abstract 738, Fifth Decennial Conference on Healthcare-Associated Infections, Atlanta, GA, March 18-22, 2010.

117. Sax H, Allegranzi B, Chraïti MN, Boyce J, Larson E, Pittet D. The
World Health Organization hand hygiene observation method. Am J Infect Control 2009; 37:827-34.

118. Indikatorer för utvärdering av kvaliteten i äldres läkemedelsterapi. Socialstyrelsens förslag. Stockholm: Socialstyrelsen 2003.

119. Jyrkkä J, Enlund H, Korhonen MJ, Sulkava R, Hartikainen S. Patterns of drug use and factors associated with polypharmacy and excessive polypharmacy in elderly persons: results of the Kuopio 75+ study: a crosssectional analysis. Drugs Aging 2009;26:493-503.

120. Indikatorer. Läkemedel förskrivna och uthämtade från apotek. I: Nationella kvalitetsindikatorer. Vården och omsorgen om äldre personer, ss. 4050. Stockholm: Socialstyrelsen 2009.

121. Field TS, Gurwitz JH, Avorn J, McCormick D, Jain S, Benser M, Bates DW. Risk factors for adverse drug events among nursing home residents. Arch Intern Med 2001; 9:1629-34.

122. Field TS, Gurwitz JH, Harrold LR, Rotchild J, DeBellis KR, Seger AC, et al. Risk factors for adverse drug events among older adults in the ambulatory setting. J Am Geriatr Soc 2004; 52:142-9.

123. Oladimeji O, Farris KB, Urmie JG, Doucette WR. Risk factors for selfreported adverse drug events among Medicare enrollees. Ann Pharmacother 2008; 42:53-61.

124. Chrischilles E, Rubenstein L, Van Gilder R, Voelker M, Wright K, Wallace R. Risk factors for adverse drug events in older adults with mobility limitations in the community setting. $\mathrm{J}$ Am Geriatr Soc 2007;5 5:29-34.

125. Baranzi F, Diurni M, Ceccon F, Poloni N, Cazzamalli S, Constantini C et al. Fall-related injuries in a nursing home setting: is polypharmacy a risk 
factor? BMC Health Serv Res 2009; 9:228.

126. Field TS, Gilman BH, Subramanian

S, Fuller JC, Bates DW, Gurwitz JH. The costs associated with adverse drug events among older adults in the ambulatory setting. Med Care 2005; 43:1171-6.

127. Linjakumpu T, hartikainen S, Klaukka K, Koponen H, Kivelä SL, Isoaho R. Psychotropics among the home-dwelling elderly - increasing trends. Int J Geriatr Psychiatry 2002; 17:874-83.

128. Gören JL, Parks JJ, Ghinassi FA, Milton CG, Oldham JM, Hernandez P, Chan J, Hermann RC. When is antipsychotic polypharmacy supported by research evidence? Jt Comm J Qual Patient Saf 2008; 34:571-82.
129. Janssen B, Weinmann S, Berger M, Gaebel W. Validation of polypharmacy process measures in inpatient schizophrenia care. Schizophr Bull 2004; 30:1023-33.

130. Mann E, Köpke S, Haastert B, Pitkälä K, Meyer G. Psychotropic medication use among nursing home residents in Austria: a crosssectional study. BMC Geriatr 2009; 9:18. 131. Prudent M, Dramé M, Jolly D, Trenque T, Parjoie R, Mahmoudi R et al. Potentially inappropriate use of psychotropic medications in hospitalized elderly patients in France: crosssectional analysis of the prospective, multicentre SAFEs cohort. Drugs Aging 2008; 25:933-46.

132 http://www.medbase.fi/sfinx/swe_ pages/om_sfinx.htm. 


\section{Kapitel}

\subsection{Nordisk kvalitetsmåling af patienterfaringer i sundhedsvæsenet}

\subsubsection{Formål med indikatorer om pasientopplevd kvalitet}

Det nyutviklede instrumentet NORPEQ, for måling av pasientopplevd kvalitet for voksne døgnsomatiske pasienter i de nordiske landene, videreutvikles for å kunne benyttes for ambulante somatiske pasienter samt for ambulante og døgnpsykiatriske pasienter.

Nasjonale målinger av pasienterfaringer i helse- og omsorgstjenesten i samtlige nordiske land koordineres og gjennomføres med passende intervall. Resultatene av gjennomførte målinger av pasienterfaringer i helse- og omsorgstjenesten bearbeides og presenteres på en åpen og sammenlignbar måte i de nordiske landene.

En struktur for samnordisk forvaltning av måleinstrumentene og regelmessige målinger etableres.

\subsubsection{Introduksjon}

Pasienters erfaringer og tilfredshet er en viktig del av kvaliteten på helsetjenesten (1-2). Både kvalitetsindikatorprosjektene i OECD og Nordisk ministerråd har brukererfaringer som et helt sentralt fokusområde, og også EU understreker dette i sitt konseptuelle kvalitetsrammeverk.

De nordiske landene samarbeider om å utvikle kvalitetsindikatorer for helsetjenesten. En av arbeidsgruppene har arbeidet med indikatorer for pasientopplevd kvalitet. Første fase i arbeidet ble gjennomført fra 2005-2007, mens nåværende fase har pågått fra 2007 til 2010. 
Spørreskjemaundersøkelser blant pasienter er basis for indikatorer for pasientopplevd kvalitet, ofte postale undersøkelser blant et utvalg pasienter. Til forskjell fra de andre arbeidsgruppene i prosjektet er altså datakilden pasienter, ikke data fra sykehusene eller andre registre.

Spørreskjemametodikk er et eget fagfelt med strenge krav i alle faser, fra konstruksjon av utvalg, til utvikling av spørreskjema og gjennomføring av undersøkelsen. Det ble derfor tidlig klart, at det var behov for å utvikle et standardisert metodeopplegg sammen med indikatorsettet for å sikre sammenlignbarhet mellom landene.

I motsetning til målinger av den faglige og organisatoriske kvaliteten baseres målinger av den pasientopplevde kvaliteten på pasientenes subjektive tilbakemeldinger om erfaringer og vurderinger. Resultater av undersøkelser av den pasientopplevde kvaliteten kan derfor være påvirket av måleinstrumentets design, og ved sammenligninger av resultater på tvers av land kan kulturelle faktorer påvirke pasientenes svar. Utvikling av en adekvat case-mix modell er derfor viktig, når landene skal sammenlignes, i tillegg til at organisatoriske og kulturelle forskjeller må inn i tolkningen av forskjellene.

Nedenfor beskrives kort første fase og nåværende fase av det nordiske prosjektsamarbeidet om indikatorer for pasientopplevd kvalitet.

Første prosjektfase (2005-2007)

I første fase var oppdraget til undergruppen for pasientopplevd kvalitet å framskaffe indikatorer og måleinstrument for å gjenspeile pasientopplevd kvalitet. Mandatet var å foreslå 6-12 potensielle indikatorer, som kan danne grunnlaget for registrering og overvåking av feltet i forhold til sammenligning av data på tvers av de nordiske landene.

På dette tidspunktet var det kun noen få land, som hadde gjennomført nasjonale pasienterfaringsundersøkelser. De eksisterende undersøkelsene var også noe forskjellige, og det var derfor ingen muligheter til å sammenligne pasienterfaringer mellom landene. Valget sto derfor primært mellom å utvikle og validere et felles nordisk instrument, eller å velge et lite knippe felles spørsmål, som kunne bli inkludert i eksisterende spørreskjemaer. Av hensyn till tidsrammer og tilgjengelige ressurser ble det siste alternativet valgt.

Gruppen ble enig om 8 pasienterfaringsspørsmål for voksne døgnsomatiske pasienter, hvorav 6 handlet om relasjon til helsepersonell, ett var om feilbehandling og ett om generell tilfredshet. Pilottesting og validering av disse spørsmålene i Norge viste, at instrumentet har god reliabilitet og validitet (3). 
De åtte spørsmålene fikk navnet NORPEQ (NORdic Patient Experiences Questionnaire), og gruppen laget metoder for oversettelse, kognitive intervjuer og pilotundersøkelse i de andre nordiske landene.

Norge inkluderte NORPEQ i en nasjonal undersøkelse i 2006. Målet var, at de andre landene skulle inkludere NORPEQ $\mathrm{i}$ kommende nasjonale undersøkelser, men først etter oversettelse, kognitive intervjuer og pilotundersøkelse i det enkelte land. Den første prosjektfasen identifiserte flere barrierer forbundet med å inkludere NORPEQ i andre nasjonale undersøkelser, både når det gjelder finansiering, nasjonal infrastruktur og lovverk.

Første prosjektfase ble derfor fokusert på å ferdigstille NORPEQinstrumentet og validere det i Norge, samt å få NORPEQ oversatt og testet $\mathrm{i}$ de andre landene.

Nåvcrende prosjektfase (2007-2010)

Nordisk Ministerråd besluttet å nedsette en nordisk prosjektgruppe med henblikk på videreutvikling av indikatorer for pasienterfaringer (4).

Prosjektgruppen for pasienterfaringer fikk i oppdrag å utarbeide forslag til indikatorer, som kan danne grunnlag for registrering og overvåkning av kvaliteten av helsetjenestens ytelser i de nordiske landene.

I tråd med formålet og målsetningene for denne fasen skulle det nyutviklede instrumentet NORPEQ videreutvikles for å kunne benyttes for ambulante somatiske pasienter, samt for ambulante og døgnpsykiatriske pasienter. Et annet mål var å koordinere og gjennomføre nasjonale målinger av pasienterfaringer i helse- og omsorgstjenesten i samtlige nordiske land med et passende tidsintervall.

En forutsetning for nasjonale undersøkelser er, at hvert land først gjennomfører standard oversettelse og testing av NORPEQ-instrumentet. Dette inkluderer forover og bakover oversettelse, kognitive intervjuer og pilotundersøkelse. Dette har vist seg å være utfordrende å få gjennomført i alle landene, og i praksis har derfor arbeidsgruppen i denne fasen hatt hovedfokus på oversettelse og testing av NORPEQ i de andre nordiske landene.

Organisering av arbeidet (2007-2010)

Infrastruktur, økonomi, juridiske rammebetingelser m.m. varierer en del mellom de nordiske landene. Det ble derfor laget landspesifikke handlingsplaner tilpasset hvert lands forutsetninger for å delta i og gjennomføre prosjektet. I 
tillegg til de landsspesifikke handlingsplanene ble det laget en felles handlingsplan for de overgripende problemstillingene.

Kravet til representantene i prosjektgruppen var, at de skulle ha faglig innsikt i området vedr. pasienterfaringer, herunder OECD-indikatorarbeidet. Kunnskapssenteret har fungert som formann og sekretariat for arbeidsgruppen, og Øyvind Andresen Bjertnæs som prosjektleder.

Hvert land har hatt en delprosjektleder med ansvar for handlingsplanen i det enkelte land, og for gjennomføring av aktivitetene i prosjektet i tråd med vedtatt metode. Sekretariat i Norge har bistått med råd og støtte til de enkelte land, samt metode- og analysekompetanse på de prosjektaktivitetene som er på tvers av landene.

Medlemmer i arbeidsgruppen har vært som følger:

- Danmark: Bjørn Ursin Knudsen, fuldmægtig, Sundhedsstyrelsen (delprosjektleder)

- Finland: Ritva Teräväinen, gruppesjef, Stakes/THL Institutet för hälsa och välfärd (delprosjektleder), og Erna Snellman, ministerial counsellor, Social- og hälsovårdsministeriet. Utviklingsleder Tuija Leinonen fra Institutet för hälsa och välfärd overtok og representerte Finland fra 2009.

- Færøyene: Jan Simonsen, rådgiver, Social- og Sundhedsministeriet (delprosjektleder)

- Island: Margrét Björnsdóttir, avdelingssjef, Sundhedsministeriet (delprosjektleder)

- Norge: Øyvind Andresen Bjertnces, forskningsleder, Kunnskapssenteret (delprosjektleder). Andrew Garratt, seniorforsker Kunnskapsenteret. Marit Kise, seniorrådgiver, Helsedirektoratet

- Sverige: Birgitta Eriksson, prosjektleder, Socialstyrelsen (delprosjektleder fra mai 2009). Birgitta Edström, handläggare, Sveriges Kommuner og Landsting (delprosjektleder til april 2009). Edstrøm har blitt pensjonist og ble erstattet av Sofia Tulberg. 


\subsection{Valg av og begrunnelse for prioriterte indikatorer}

\subsubsection{Innledning}

I arbeidsgruppen for pasientopplevd kvalitet var mandatet i første prosjektfase (2005-2007) å foreslå 6-12 potensielle indikatorer, som kan danne grunnlaget for registrering og overvåking av feltet i forhold til sammenligning av data på tvers av de nordiske landene.

I tre av de nordiske landene var det planlagt nasjonale pasienterfaringsundersøkelser i 2006 blant voksne somatiske døgnpasienter. Disse undersøkelsene ble i første prosjektfase (2005-2007) identifisert som mulig datakilde for kvalitetsindikatorer vedr. pasientopplevd kvalitet (alternativ A). Andre alternativer ble også vurdert, som WHOs helseundersøkelse (B), nordiske initiativer ifht. gjennombruddsprosjekter (C), samt en egen nordisk undersøkelse med basis i et større forskningsprosjekt (D).

Gruppen valgte alternativ A etter en samlet vurdering av økonomiske, administrative og metodologiske forhold. På dette tidspunktet var det ikke iverksatt et eget delprosjekt om pasienterfaringer i OECD, og ingen av de nordiske landene deltok i Commonwealth Funds internasjonale undersøkelser.

Det ble tidlig klart at ingen av landene ønsket å gå bort fra eksisterende nasjonale pasienterfaringsundersøkelser. Dermed måtte gruppen legge til grunn at de nordiske indikatorene skulle integreres som supplement i eksisterende undersøkelser i det enkelte land.

Som grunnlag for å velge 6-12 indikatorer valgte gruppen å gjennomføre en utviklings- og valideringsprosess med utgangspunkt i Kunnskapssenterets standardmetoder. I tillegg var det nødvendig å utarbeide oversettelsesrutiner for å sikre konseptuell likhet mellom pasienterfaringsspørsmålene i de ulike landene. En oversikt over utviklings- og valideringsmodell for spørreskjemaet finnes i tabell 1 nedenfor, og hver aktivitet beskrives i de følgende avsnitt.

\subsubsection{Generering av spørsmål}

De viktigste kriteriene for utvikling av skjemaet ble diskutert og bestemt innledningsvis. Et sentralt kriterium var å inkludere de viktigste dimensjonene av pasientens erfaringer og tilfredshet med helsetjenester, som har relevans for somatiske døgnpasienter på tvers av de nordiske landene. 
Tabell 1. Trinn i utviklingen og evalueringen av spørreskjemaet

\begin{tabular}{|c|c|c|}
\hline 1 & Generering av spørgsmål & $\begin{array}{l}\text { Litteraturgjennomgang, innhold i eksisterende nordiske skjemaer, } \\
\text { ekspertkonsensus }\end{array}$ \\
\hline 2 & Oversettelse & Fram-tilbake oversettelser \\
\hline 3 & Pasientintervjuer & Kognitiv testing \\
\hline 4 & Pilotundersøkelse & $\begin{array}{l}\text { Datakvalitet - andel missing, svarfordeling } \\
\text { Dimensjonalitet - faktoranalyse } \\
\text { Intern konsistens og test-retest reliabilitet } \\
\text { Validitet }\end{array}$ \\
\hline 5 & Hovedundersøkelse & $\begin{array}{l}\text { Datakvalitet - andel missing, svarfordeling } \\
\text { Dimensjonalitet - faktoranalyse } \\
\text { Intern konsistens og test-retest reliabilitet } \\
\text { Validitet }\end{array}$ \\
\hline
\end{tabular}

Et annet viktig kriterium var å lage et kort skjema, maks en side med akseptabel skriftstørrelse og dermed mellom 6 og 12 spørsmål. Dette skyldtes et behov for minimal økning av respondentbyrde ved integrering av de nordiske spørsmålene i eksisterende/framtidige nasjonale spørreskjemaer i de ulike landene.

Til slutt ble det bestemt å inkludere et spørsmål om generell tilfredshet som et resultatmål i tillegg til de prosessuelle pasienterfaringsspørsmålene, samt å inkludere et spørsmål om pasientopplevd feilbehandling som har sterk sammenheng med pasientvurderinger og tilfredshet.

Spørsmålene ble utviklet på grunnlag av en litteraturgjennomgang om de viktigste dimensjonene av pasienters erfaringer (5), samt en gjennomgang av temaer og spørsmål i eksisterende nordiske spørreskjemaer (se tabell 2). De eksisterende spørreskjemaene var innholdsmessig rimelig like, men svarskalaer og spørsmålsformuleringer var forskjellige.

Gjennomgangen ble utført av to av arbeidsgruppemedlemmene, og resultatene ble diskutert med arbeidsgruppen som hadde deltakere fra alle land. Den systematiske litteraturgjennomgang viste at relasjon til helsepersonell inkludert informasjon er de viktigste områdene for pasienter (5), og seks spørsmål som omhandlet dette ble trukket ut av de eksisterende nordiske spørreskjemaene. På grunn av tematisk nærhet mellom spørsmålene var det forventet, at de fleste vil bidra til én hovedfaktor, når det gjelder pasienterfaringer. Forutsatt tilfredsstillende reliabilitet kan også de enkelte spørsmål benyttes som globale mål på ulike aspekter ved pasientenes erfaringer. 
I tillegg ble som nevnt et spørsmål om generell tilfredshet og et spørsmål om feilbehandling tatt med.

Tabell 2. De mest brukte spørreskjemaene i de nordiske landene før 2006

\begin{tabular}{lll}
\hline Forfatter & Skjema & Land \\
\hline Freil et al (6) & LUP & Danmark \\
Peiponen et al (7) & Patient judgements of hospital care & Finland \\
Larsson \& Larsson (8) & MiniKUPP & Island \\
Pettersen et al (9) & Patient Experiences Questionnaire (PEQ) & Norge \\
Jenkinson et al (10) & Picker & Sverige \\
\hline
\end{tabular}

Arbeidsgruppen diskuterte de utvalgte spørsmålene, som så ble ferdigstilt og dannet grunnlag for videre uttesting. De åtte spørsmålene finnes i tabell 3 nedenfor.

Valg av svarskala er en viktig problemstilling på dette området, ettersom evalueringene som regel er veldig positive (stor grad av takeffekt). En ny studie indikerer at hver svarverdi bør ha et navn, og ikke bare beskrivelser eller navn på ytterpunktene, fordi sistnevnte trekker svarene i retning av ytterpunktene (11).

Det er ikke noe fasitsvar når det gjelder antall svarkategorier, men fem er mest vanlig i pasienttilfredshetsmålinger (12). På helseområdet har det vært argumentert for at respondentene ikke kan diskriminere tilstrekkelig ut over syv kategorier, og at flere kategorier har marginal innflytelse på estimatenes pålitelighet (13). Når flere spørsmål summeres til en skala for pasienterfaringer, er det uansett lite sannsynlig at en reduksjon av antall svarkategorier vil resultere i viktig tap av informasjon.

De nordiske spørsmålene har følgende fem-punkt svarskala: Ikke i det hele tatt, i liten grad, i noen grad, i stor grad, i svært stor grad. Denne skalaen er standard i de nasjonale brukerundersøkelsene i Norge og har vist seg å gi gyldige og pålitelige data i en rekke nasjonale undersøkelser (14-19). Fempunkt skalaen er også lett å lage med stor skriftstørrelse og dermed tilpasset eldre personer og personer med kognitive utfordringer.

I tillegg til pasienterfaringsspørsmål og svarskala diskuterte arbeidsgruppen hvilke sosiodemografiske spørsmål som bør inkluderes, enten som casemix variable eller som valideringsspørsmål. Det ble valgt å ta med spørsmål, som er standard for dette formålet i Norge og andre land, som gjennomfører 
nasjonale brukerundersøkelser, som innleggelsesmåte (elektiv/akutt), liggetid, antall innleggelser siste året, egenvurdert helse, alder og utdanning.

Det ble også tatt med et spørsmål om pasientens forventninger ble innfridd. Forventninger er viktig for å forklare variasjon i tilfredshet ifølge en systematisk gjennomgang (5). Forventningene kan variere på tvers av land, og dermed kan spørsmålet muligens fungere som en kontrollvariabel i den statistiske sammenligningen av nasjonale resultater. Et spørsmål om effekten av sykehusoppholdet på pasientens helseproblem ble tatt med av valideringsgrunner, men spørsmålet er også et enkelt mål på generelt helseutfall.

Tabell 3. Oversikt over utvalgte pasienterfaringsspørsmål (NORPEQ)

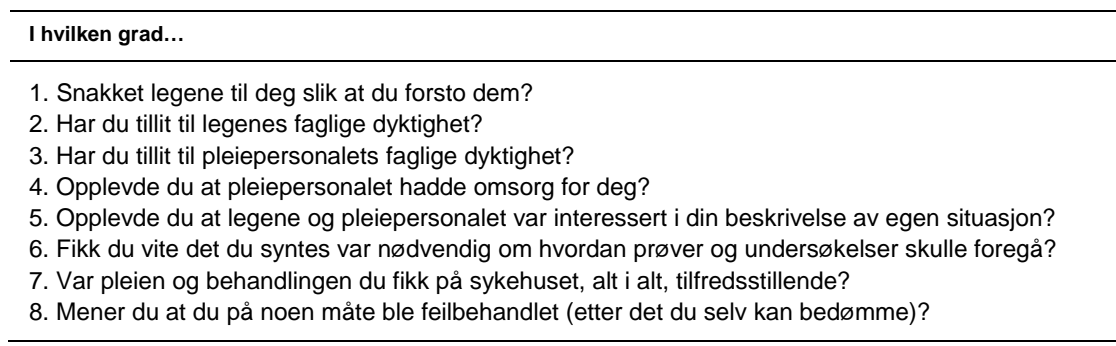

Spørreskjemaet utformes slik at det er akseptabelt for pasientene, herunder med tilfredsstillende skriftstørrelse og tydelig layout. Spørsmålene knyttet til pasienterfaringer og tilfredshet kommer først, mens bakgrunnsspørsmålene kommer etterpå. Spørsmålene om generell tilfredshet og feilbehandling kommer etter de seks pasienterfaringsspørsmålene. Det har vært argumentert for, at rekkefølgeeffekt sannsynligvis er minimal i postale selvutfyllingsskjemaer (20;21). Hele det nordiske skjemaet på norsk er vedlagt i eget bilag 8 .

\subsubsection{Oversettelse}

De åtte spørsmålene ble laget på norsk. Oversettelsesprosessen til de andre nordiske språkene ble utformet for å overholde minimumskrav for oversettelse av spørreskjemaer for pasienter, såkalt forover-bakover metode (22;23). Det var ønskelig med to forover-oversettere og to andre bakover-oversettere, helst med noe kunnskap om området og helst med erfaring i helserelatert forskning. Bakover-oversetterne skal ikke ha sett den originale norske versjonen, de bør være norske og beherske språket det skal oversettes fra. Bakover-oversettelsene ble vurdert og godkjent av Kunnskapssenteret i Norge, som avgjorde om spørsmå- 
lene hadde beholdt sin opprinnelige mening, og om det var noen uklarheter. Kravet var konseptuell likhet, ikke ordrett oversettelse. Et annet krav var språklig enkelhet, noe som var et mål i den norske baselineversjonen.

NORPEQ er oversatt til svensk, finsk, islandsk, dansk og færøysk. Oversettelsene har fungert tilfredsstillende og har ikke gitt grunnlag for justeringer av de åtte spørsmålene på norsk. Det har vært små justeringer i de fleste oversettelser, og den største utfordringen har omhandlet oversettelse av begrepet pleiepersonalet. I Norge inkluderes sykepleiere og hjelpepleiere, mens det i andre land er andre grupper involvert, eller det mangler et lignende begrep. Prosessene har pågått inntil tilfredsstillende oversettelser har vært på plass, for eksempel har Sverige benyttet begrepet «skøterskor» for å sikre likhet med norsk spørsmål.

En oversikt over godkjente versjoner av spørsmålene på andre språk finnes i bilag 9-13. Oppsettet er noe ulikt fordi spørsmålene er hentet fra ulike kilder, for eksempel er spørsmålene hentet fra pilotskjemaene i Finland og Sverige og det nasjonale skjemaet på Færøyene. Ettersom hvert land har ulike nasjonale brukererfaringsskjemaer, er minste felles multiplum at de åtte spørsmålene har samme spørsmålsformulering og svarkategorier. Gullstandarden er selvfølgelig, at spørsmålene er plassert samme sted i skjema med samme rekkefølge og lik layout, innledningstekst m.m.

\subsubsection{Kognitive intervjuer}

De åtte spørsmålene er testet i kognitive intervjuer i Norge, Sverige, Finland, Danmark, Færøyene og Island. Hensikten med intervjuene var å kartlegge, hvor godt pasientene forstår spørsmålene, om det er uklarheter, om spørsmålene er vanskelige å besvare, samt om svarkategoriene oppleves som dekkende.

Intervjuene ble gjennomført på en strukturert måte. Spørsmålene ble lest opp for pasienten, som så besvarte spørsmålet. I intervjuguiden var det satt av plass for hvert spørsmål, slik at intervjuer kunne registrere hvor vanskelig spørsmålet er, om spørsmålet oppleves som relevant, samt om svarkategoriene oppleves som dekkende. I tillegg var det satt av plass til ytterligere kommentarer på hvert spørsmål.

De kognitive intervjuene viste, at de åtte spørsmålene oppleves som relevante og forståelige i alle landene. I Danmark er det laget en egen rapport om de kognitive intervjuene, som konkluderte med at spørsmålene fungerer godt (24). En forklaring på de gode resultatene er at spørsmålene er generiske og 
ble utviklet for å være enkle å besvare, med fokus på hverdagsspråk på lavt lesenivå.

Alt i alt gav ikke de kognitive intervjuene grunnlag for å endre på spørsmålene. Samtidig pekte intervjuene i noen tilfeller på flere forbedringspunkter, når det gjaldt selve oversettelsen av spørsmålene, for eksempel når det gjaldt spørsmålet om feilbehandling på færøysk. Små justeringer har derfor blitt gjort i lys av de kognitive intervjuene, men innenfor rammene av kravet til konseptuell likhet med de opprinnelige spørsmålene på norsk..

\subsubsection{Pilotundersøkelse}

Det er gjennomført pilotundersøkelser av NORPEQ i Norge, Sverige og Finland. Skjemaet ble først validert i Norge (3). Nylig er det også innsendt en vitenskapelig artikkel med statistiske analyser av data fra pilotundersøkelsene i Sverige og Finland, samt pilot- og nasjonale data i Norge. Denne studien blir også presentert på ISQua-konferansen i Paris høsten 2010.

NORPEQ ble testet på voksne døgnsomatiske pasienter utskrevet fra ett universitetssykehus i hvert av landene, i tillegg til at NORPEQ var inkludert i en nasjonal undersøkelse i Norge i 2006. 500 tilfeldig utvalgte pasienter ble trukket ut til å delta fra hvert universitetssykehus.

Dimensjonalitet i skjemaet ble vurdert ved hjelp av faktoranalyse og intern konsistens reliabilitet vha. item-total korrelasjon og Cronbach's alpha. Begrepsvaliditet ble vurdert ved å korrelere NORPEQ med variable som har dokumentasjon for sammenheng med pasienterfaringer.

Andel missing på de åtte enkeltspørsmålene var liten i alle landene, noe som indikerer relevans og aksept for spørsmålene blant pasienter. Det ble identifisert én hoveddimensjon av pasienterfaringer, i tillegg til enkeltspørsmål om generell tilfredshet og feilbehandling. Analysene gav grunnlag for å konkludere med at NORPEQ har god dokumentasjon av reliabilitet og begrepsvaliditet i de tre landene.

\subsection{Resultater av nasjonal datainnsamlingen}

Det er en fordel med samme datainnsamlingsmetoder i alle landene. Dette er imidlertid ikke realistisk slik situasjonen er i de nordiske landene når det gjelder 
nasjonale brukerundersøkelser. Det er etablert systemer og undersøkelser som er forskjellige, og som har tidsserier og andre nasjonale forhold å hensynta.

Arbeidsgruppen har derfor definert en minimumsløsning for datainnsamlingen på dette området. Det er viktig med et nasjonalt representativt utvalg, minimum 4000 pasienter fra 15-20 sykehus ev. alle sykehus, dersom det gjennomføres heldekkende nasjonale undersøkelser (mindre utvalg på Island og Færøyene). Inklusjons- og eksklusjonskriterier må være like, ev. må det være mulig å gjøre analyser på like utvalg.

Undersøkelsen må være postal med en eller to purringer, og NORPEQ og relevante bakgrunnsspørsmål må inkluderes. Det må også lages vekter for å korrigere for frafall, samt gjøres case-mix justeringer ved sammenligning av landene.

Norge inkluderte NORPEQ i en nasjonal undersøkelse i 2006, mens Færøyene har inkludert NORPEQ i en nasjonal undersøkelse i 2010. Danmark og Sverige har gjennomført nasjonale undersøkelser, men har av ulike årsaker valgt å ikke inkludere NORPEQ. Island og Finland har ikke gjennomført nasjonale undersøkelser i perioden. Nedenfor beskrives resultater av datainnsamlingen i Norge.

\subsubsection{Norge}

Populasjonen i undersøkelse var pasienter fra og med 16 år utskrevet fra 63 somatiske sykehus i perioden 1. september til 23. november 2006. Føde- og barselenheter, somatiske poliklinikker, samt barne- og dagavdelinger ble ekskludert. Det ble trukket tilfeldig 400 pasienter per sykehus med basis i overførte pasientadministrative data. Postalt spørreskjema ble sendt hjem til pasientene én til to uker etter utskriving, og én purring ble sendt til de, som ikke hadde svart etter en måned. De 8 NORPEQ spørsmålene var integrert i spørreskjemaet, som hadde totalt 53 spørsmål.

Svarprosenten i undersøkelsen var 46 (n=10 912). Det var forskjeller på svarere og ikke-svarere på flere demografiske variable, og det ble derfor vektet for kjønn, alder, pulje, prosedyretype og diagnosegruppe. Kunnskapssenteret har konkludert med at undersøkelsen har tilfredsstillende representativitet.

Tabell 4 viser de nasjonale resultatene på NORPEQ-spørsmålene. Vi ser at $31,6 \%$ av respondentene opplevde problemer knyttet til informasjon om prøver og undersøkelser, mens 29,0 \% opplevde problemer med manglende interesse fra legene og pleiepersonalet, når det gjelder pasientens egen oppfat- 
ning av situasjonen. Ifølge pasientene opplevde 11,8 \% feilbehandling, noe som er den minste problemandelen på de åtte spørsmålene. På NORPEQindeksen var det nasjonale gjennomsnittet 75,7 på en skala fra 0 til 100, der 100 er beste skår.

Pasientene i Norge rapporterer altså gode erfaringer med sykehusene, samtidig som det finnes forbedringsområder blant annet når det gjelder informasjon og brukerorientering. Det er ikke mulig å vite om erfaringene er bedre eller dårligere enn i andre nordiske land, og både sammenligning med andre land totalt og brutt ned på aldersgrupper, kjønn og andre variable vil være nyttig, når resultatene skal tolkes og benyttes i ulike sammenhenger. Det bør også vurderes andre måter å framstille indikatorene på (ut over problemskår og gjennomsnittsverdi), samt hvordan nasjonale resultater skal justeres og presenteres ved sammenligning av land.

Tabell 4 Resultater på NORPEQ-spørsmålene i Norge (2006)

\begin{tabular}{|c|c|c|c|c|}
\hline & Missing (\%) & $\mathbf{N}$ & Gjennomsnitt & Problem \% \\
\hline NORPEQ INDEKS (a) & $2030(2,1)$ & 10849 & 75,7 & 20,8 \\
\hline Snakket legene til deg slik at du forsto dem? & $313(2,8)$ & 10766 & 4,0 & 19,9 \\
\hline $\begin{array}{l}\text { Opplevde du at legene og pleiepersonalet var } \\
\text { interessert i din beskrivelse av egen situation? }\end{array}$ & $395(3,6)$ & 10684 & 3,9 & 29,0 \\
\hline $\begin{array}{l}\text { Opplevde du at pleiepersonalet hadde } \\
\text { omsorg for deg? }\end{array}$ & $306(2,8)$ & 10773 & 4,2 & 15,7 \\
\hline Har du tillit til legenes faglige dyktighet? & $334(3,0)$ & 10745 & 4,2 & 15,6 \\
\hline Har du tillit til pleiepersonalets faglige dyktighet? & $327(3,0)$ & 10752 & 4,2 & 14,4 \\
\hline $\begin{array}{l}\text { Fikk du vite det du syntes var nødvendig om } \\
\text { hvordan prøver og undersøkelser skulle foregå? }\end{array}$ & $380(3,4)$ & 10699 & 3,8 & 31,6 \\
\hline \multicolumn{5}{|l|}{ NORPEQ: TO ENKELTSPøRSMÅL } \\
\hline $\begin{array}{l}\text { Mener du at du på nogen måte har blitt feilbe- } \\
\text { handlet (Etter det du selv kan bedømme)? }\end{array}$ & $521(4,7)$ & 10558 & 4,6 & 11,8 \\
\hline $\begin{array}{l}\text { Var pleien og behandlingen du fikk på syke- } \\
\text { huset, alt i alt, tilfredsstillende? }\end{array}$ & $427(3,9)$ & 10652 & 4,2 & 13,6 \\
\hline
\end{tabular}

Noter. Gjennomsnitt: Indeks: gjennomsnitt skala 0 til 100 der 100 er best. Enkeltspørsmål: gjennomsnitt skala 1 til 5 der 5 er best. Problem \%: Indeks: \%-andel 62,5 eller lavere på indeks. Enkeltspørsmål: \%-andel som har svart ett av de tre dårligte svaralternativene. 


\subsection{Valg av og begrunnelse for potensielle indikatorer}

\subsubsection{Videreutvikling av NORPEQ}

NORPEQ er tilpasset voksne døgnsomatiske pasienter, som er en viktig men begrenset pasientgruppe når vi ser på spesialist- og primærhelsetjenesten samlet. Det er også en av de mer tilfredse pasientgruppene, mens andre grupper for eksempel innenfor psykiatrien rapporterer langt større forbedringspotensial.

Et av hovedmålene i denne fasen av det nordiske arbeidet har vært å videreutvikle NORPEQ til psykiatri og somatikk poliklinikk. Nasjonalt kunnskapssenter for helsetjenesten og sekretariatet i Norge har utviklet og testet 10 generiske kjernespørsmål, som kan brukes på tvers av ni pasientgrupper inkludert psykiatri og poliklinikk somatikk (25). Spørsmålene er basert på spørsmål om pasientprioriteringer i en undersøkelse i Norge høsten 2008.

Følgende pasientgrupper i spesialisthelsetjenesten var inkludert: Voksne døgnsomatiske og ambulante pasienter; voksne døgnpsykiatriske og polikliniske pasienter; voksne polikliniske rehabiliteringspasienter; pårørende ved somatiske barneavdelinger; pårørende ved barne- og ungdomspsykiatriske poliklinikker; voksne brukere av døgnenheter og poliklinikker innenfor rusområdet. De ti spørsmålene er som følger:

- Snakket behandlerne til deg slik at du forsto dem?

- Har du tillit til behandlernes faglige dyktighet?

- Fikk du tilstrekkelig informasjon om din diagnose/dine plager?

- Opplevde du at behandlingen var tilpasset din situasjon?

- Var du involvert i avgjørelser som angikk din behandling?

- Opplevde du at institusjonens arbeid var godt organisert?

- Måtte du vente for å få tilbud ved institusjonen?

- Var hjelpen og behandlingen du fikk på institusjonen, alt i alt, tilfredsstillende?

- Hvilket utbytte har du hatt, alt i alt, av behandlingen på institusjonen?

- Mener du at du på noen måte ble feilbehandlet (etter det du selv kan bedømme)?

Det er også mulig å supplere med 1-3 spørsmål for den enkelte gruppe for å øke innholdsvaliditeten. 
Dette instrumentet er nå tilgjengelig for de andre nordiske landene, og kan utgjøre potensielle nordiske indikatorer på sikt. Instrumentet er basert på relevans og viktighet for pasienter, og er dermed et godt grunnlag for generiske indikatorer om pasientopplevd kvalitet.

Basert på tilbakemelding fra styringsgruppen har vi ikke arbeidet videre med oversettelse, kognitive intervjuer og pilottester av dette instrumentet i denne fasen. På sikt bør imidlertid målinger av pasientopplevd kvalitet utvides til flere pasientgrupper i primær- og spesialisthelsetjenesten også i det nordiske arbeidet.

\subsubsection{Andre internasjonale undersøkelser}

Kvalitesindikatorprosjektet i OECD er i ferd med å utvikle og teste et skjema for pasienterfaringer (responsiveness), i første omgang når det gjelder ambulante pasienter. Populasjonsbaserte undersøkelser i OECD er muligens etablert fra 2011 eller 2012.

Både Sverige og Norge deltar i Commonwealth Funds internasjonale undersøkelser, og disse er også aktuelle å vurdere til bruk i nordisk sammenheng.

Dersom de nordiske landene deltar i OECD og/eller Commonwealth Funds internasjonale undersøkelser vil data fra disse undersøkelsene være fritt tilgjengelig for det nordiske kvalitetsindikatorsystemet. Hvilke konkrete indikatorer, som kan utgå fra OECD og Commonwealth Fund på dette området må vurderes senere, når prosjektene har kommet lenger og flere nordiske land deltar.

\subsection{Diskusjon}

Prosjektgruppen har valgt en tilnærming, hvor pasienter med nylig kontakt med en helseinstitusjon skal gi en tilbakemelding om sine erfaringer med helseinstitusjonen. Det er gjennomført nasjonale pasienterfaringsundersøkelser på denne måten tidligere både i Sverige, Island, Færøyene, Danmark og Norge. Formålet er at tilbakemeldingene skal kunne benyttes til kvalitetsforbedring, virksomhetsstyring og som grunnlag for åpenhet, etterrettelighet og sykehusvalg. 
En stor utfordring er å sikre nødvendig infrastruktur i alle landene for å gjennomføre nasjonale pasienterfaringsundersøkelser. Pasientutvalgene konstrueres med basis i de pasientadministrative systemene ved institusjonene. Per i dag har Sverige, Danmark, Færøyene (kjøper fra Danmark) og Norge robuste kompetansemiljøer med nasjonale funksjoner, systemer for å samle inn data fra pasienter og med etablerte tekniske og praktiske rutiner. Island er i en slags mellomposisjon, fordi de har gjennomført én nasjonal undersøkelse tidligere. Finland har per i dag ikke et nasjonalt system, og har i tillegg hatt juridiske problemer pga. taushetsplikten.

Sammenlignbare undersøkelser av pasienterfaringer i Norden forutsetter, at det i det enkelte land eksisterer nødvendig nasjonal infrastruktur (kompetanse, systemer og rutiner). Arbeidsgruppen anbefaler derfor, at eksisterende eller planlagte nasjonale systemer for pasienterfaringsundersøkelser er basis for systematisk datainnsamling på vårt område.

En annen viktig utfordring på vårt område er nasjonal forankring av nordiske indikatorer. Danmark og Sverige gjennomfører nasjonale brukerundersøkelser, men har av ulike årsaker ennå ikke hatt anledning til å inkludere de nordiske NORPEQ-spørsmålene. Arbeidsgruppen peker derfor på viktigheten av, at inkludering av NORPEQ i nasjonale pasienterfaringsundersøkelser forankres gjennom eksplisitte helsepolitiske beslutninger i det enkelte land, og at dette følges opp i årene som kommer.

Andre internasjonale undersøkelser som OECD og Commonwealth Fund er aktuelle som basis for indikatorer på vårt område. OECD arbeider forskningsbasert på pasienterfaringsområdet, mens Commonwealth Funds internasjonale undersøkelser har vært noe kritisert for manglende metodekvalitet. Fordelene med begge undersøkelsene er, at de er relativt billige sammenlignet med store pasienterfaringsundersøkelser, og at man kan nå mange ulike subpopulasjoner. En ulempe er at undersøkelsene i begrenset grad kan benyttes til lokalt kvalitetsforbedringsarbeid.

Antakeligvis er en kombinasjon av nasjonale pasienterfaringsundersøkelser og OECD/Commonwealth Fund mest nyttig, hvor de sistnevnte er mest tilpasset systemnivå, mens pasienterfaringsstudier også er nyttige på lavere nivå.

Hvilke konkrete indikatorer som kan utgå fra OECD og Common-wealth Fund på dette området, må vurderes senere, når flere nordiske land deltar. Det bør også vurderes om bredere «ytelsesindikatorer» (performance measures) skal inkluderes i det nordiske prosjektet i tillegg til kvalitetsindikatorer. 


\subsection{Perspektiver}

NORPEQ-spørsmålene bør kunne inkluderes i eksisterende nasjonale pasienterfaringsundersøkelser i de nordiske landene. Forutsatt rask nasjonal forankring og implementering vil nordiske land kunne sammenligne indikatorer for pasientopplevd kvalitet i løpet av noen år. Imidlertid er det viktig at også andre pasientgrupper enn døgnsomatiske pasienter inkluderes. Arbeidsgruppen peker på det nevnte generiske instrumentet som mulig grunnlag for nordiske pasienterfaringsindikatorer på tvers av ulike pasientgrupper. For å lykkes med dette, er det nødvendig med eksplisitte helsepolitiske beslutninger i det enkelte land, og avsetning av ressurser til validering og gjennomføring.

Kvalitetsindikatorer har ulike formål som kvalitetsforbedring, virksomhetsstyring, sykehusvalg og samfunnsmessig etterrettelighet. De åtte spørsmålene, som er utviklet (NORPEQ), kan inkluderes i nasjonale pasienterfaringsundersøkelser i de nordiske landene, og kan brukes som grunnlag for alle formålene i det enkelte land, samt til nordiske sammenligninger av pasientopplevd kvalitet.

Arbeidsgruppen anbefaler å supplere de nordiske indikatorene med tall fra OECD responsiveness prosjektet når de er klare, noe som vil gi et bredere grunnlag for å vurdere pasientopplevd kvalitet enn de åtte nordiske spørsmålene kan gjøre alene. OECD-indikatorer vil være bedre egnet til å vurdere helsetjenestesystemet i det enkelte land ettersom de bygger på befolkingsundersøkelser, mens de nordiske indikatorene hentet fra pasienterfaringsundersøkelser kan brukes som grunnlag for flere av formålene til kvalitetsindikatorer.

Bruk av spørreskjemaer som grunnlag for indikatorer vil mest sannsynlig øke i tiden framover, både når det gjelder pasienterfaringer, pasientopplevd pasientsikkerhet, pasientrapporterte utfallsmål, og andre indikatorer som for eksempel pasientsikkerhetskultur. Arbeidsgruppen for pasientopplevd kvalitet har utviklet en modell som kan gjenbrukes på andre områder, men erfaringene fra dette nordiske prosjektet viser viktigheten av nasjonal forankring og oppfølging, samt nasjonal infrastruktur og kompetanse. Utvikling, testing og implementering av spørreskjemabaserte indikatorer er annerledes enn andre type indikatorer.

Arbeidsgruppen anbefaler derfor at det utarbeides standardiserte metoder for utvikling og testing av slike indikatorer i det nordiske indikatorarbeidet. 


\section{Referanser}

1. Donabedian A. The quality of care. How can it be assessed? JAMA 1988; 260: $1743-1748$.

2. Kelley E, Hurst J. Health Care Quality Indicators Project: Conceptual Framework Paper. OECD Health Working Papers 23-2006. Paris: OECD, 2006.

3. Oltedal S, Garratt A, Bjertnaes Ø, Bjørnsdottìr M, Freil M, Sachs M. The NORPEQ patient experiences questionnaire: data quality, internal consistency and validity following a Norwegian inpatient survey. Scand J Public Health. 2007;35(5):540-7.

4. Kvalitetsmåling i sundhedsvæsenet i Norden. TemaNord 2007:519.

5. Crow R, Gage H, Hampson S, Hart J, Kimber A, Storey L, Thomas H. The measurement of satisfaction with healthcare: implications for practice from a systematic review of the literature. Health Technol Assess. 2002; 6:1-244.

6. Freil M, Lorentzen J, Rasmussen L, Gut R, Knudsen JL. Patientexperienced quality assessed in two national surveys Ugeskr Laeger. 2005;167:4 375-9.

7. Peiponen A, Brommels M, Kupiainen O. Vakioitu potilastyytyväisyyden mittari. Finska Läkartidningen 1996; 51 (18-19): 2 042-2 048.

8. Larsson BW, Larsson G. Developement of a short form of the questionaire: Quality from the patient's perspective. J. of Clinical Nursing 2002;11:681-7

9. Pettersen KI, Veenstra M, Guldvog B, Kolstad A. The Patient Experiences Questionnaire - development, validity and reliability. Int J Qual Health Care 2004;16(6):453-63.
10. Jenkinson C, Coulter A, Bruster S. The Picker Patient Experience Questionnaire: development and validation using data from in-patient surveys in five countries. Int J Qual Health Care 2002; 14(5):353-8.

11. Garratt A, Helgeland J, Gulbrandsen P. Item scaling for the Patient Experiences Questionnaire (PEQ): a randomized comparison of five- and ten-point scales (in press).

12. Sitzia J. How valid and reliable are patient satisfaction data? An analysis of 195 studies. Int J Qual Health Care. 1999; 11:319-28.

13. Streiner DL, Norman GR. Health measurement scales: a practical guide to their development and use (3rd ed.). Oxford: Oxford University Press, 2003.

14. Bjertnaes OA, Garratt A, Nessa J. The GPs' Experiences Questionnaire (GPEQ): reliability and validity following a national survey to assess GPs' views of district psychiatric services. Fam Pract. 2007; 24:336-42.

15. Garratt AM, Bjertnaes OA, Barlinn J. Parent experiences of paediatric care (PEPC) questionnaire: reliability and validity following a national survey. Acta Paediatr. 2007;96:246 -52.

16. Danielsen K, Garratt AM, Bjertnaes $\varnothing \mathrm{A}$, Pettersen KI. Patient experiences in relation to respondent and health service delivery characteristics: a survey of 26,938 patients attending 62 hospitals throughout Norway. Scand J Public Health. 2007;35(1):70-7.

17. Garratt A, Danielsen K, Bjertnaes ØA, Ruud T. PIPEQ-a method for measurement of user satisfaction in mental health services. Tidsskr Nor Laegeforen. 2006 May 25;126(11):1 478-80. 
18. Garratt A, Bjørngaard JH, Dahle KA, Bjertnaes OA, Saunes IS, Ruud T. The Psychiatric Out-Patient Experiences Questionnaire (POPEQ): data quality, reliability and validity in patients attending 90 Norwegian clinics. Nord J Psychiatry. 2006;60(2):891996-Garratt AM, Bjaertnes ØA, Krogstad U, Gulbrandsen P. The OutPatient Experiences Questionnaire (OPEQ): data quality, reliability, and validity in patients attending 52 Norwegian hospitals. Qual Saf Health Care. 2005; 14:433-7.

20. Smith TW. Condition order effects (GSS technical report no. 33). Chicago, IL: National Opinion Research Centre, 1982.

21. Hipper H-J, Schwartz N. Response effects in surveys. In: Hipper H-J, Schwartz N, Sudman S (Eds.). Social Information Processing and Survey Methodology. New York: SpringerVerlag, 1987.
22. Bradley C. Translation of questionnaires. In Handbook of Psychology and Diabetes. C Bradley Ed. Switzerland: Harwood, 1994.

23. Leplege A, Verdier A. The adaptation of health status measures: methodological aspects of the translation procedure. In Schumaker S, Berzon B (Eds). International Assessment of Quality of Life: Theory, translation, measurement and analysis. Oxford: Rapid Communications, 1995

24. Validering af dansk NORPEQspørgeskema: et delprojekt under NORPEQ-projektet. Rapport december 2009, Center for Kvalitetsudvikling, Region Midtjylland.

25. Sjetne IS, Bjertnæs ØA, Iversen HH, Olsen RV. Pasienterfaringer i spesialisthelsetjenesten. Et generisk, kort spørreskjema. Notat 2009, Nasjonalt kunnskapssenter for helsetjenesten. 


\section{Kapitel}

\subsection{Konklusioner og anbefalinger}

I de nordiske lande er der et stort potentiale for måling og monitorering af kvaliteten af sundhedsvæsenets ydelser. Det kan konkluderes, at det er muligt at identificere relevante kvalitetsindikatorer på tværs af landene.

Denne rapport viser ligeledes, at der på en række kliniske områder kan tilvejebringes data, som kan anvendes til sammenligning og benchmarking mellem de nordiske lande.

I internationalt perspektiv er de nordiske lande således blandt de lande, der er nået længst med formaliseret og systematisk kvalitetsudvikling. De nordiske lande har enestående muligheder, idet der er etableret velfungerende sundhedsregistre med mulighed for at tilvejebringe personidentificerbare data, samt mulighed for at kombinere registre således, at der kan udvikles avancerede kvalitetsindikatorer.

Denne rapport illustrerer imidlertid også, at der på kliniske områder er behov for en betydelig indsats for at sikre datakvaliteten, herunder validitet og tilvejebringelse af data på en række områder.

En række af de resultater, der er tilgængelige, kan således næppe anvendes til retvisende sammenligninger og benchmarking, men snarere til at stille spørgsmål om, hvorvidt der vitterlig eksisterer reelle forskelle i kvaliteten af ydelser. Der er derfor behov for en betydelig indsats med henblik på at sikre valide, tidstro data med henblik på retvisende sammenligning og benchmarking mellem de nordiske lande. Ligeledes er der behov for en dynamisk udvikling af potentielle kvalitetsindikatorer.

Det fremgår ligeledes, at det på vigtige områder ikke er muligt at tilvejebringe data, som gør det muligt at foretage sammenligninger mellem de nordiske lande. Det har således ikke været muligt at tilvejebringe data til belysning af patientsikkerhed i de nordiske lande. Internationalt er arbejdet 
med at udvikle kvalitetsindikatorer på dette område netop påbegyndt, og det forventes, at de nordiske lande kan bidrage til denne udvikling.

I relation til psykiatri er der behov for i øget omfang at udvikle kvalitetsindikatorer, der belyser patienternes forløb i sundhedsvæsenet.

Data på dette område er således ikke retvisende, idet lovgivningen er forskellig i de nordiske lande, hvilket indebærer, at betydningen af indikatorerne kan være forskellig.

Internationalt er dette område svagt belyst. Det vurderes, at de nordiske lande kan bidrage til, at der udvikles kvalificerede kvalitetsindikatorer på dette område ved en fællesnordisk indsats.

I relation til sundhedsfremme og forebyggelse samt børn og unge er der ligeledes betydelige vanskeligheder med retvisende tolkninger og konklusioner. Disse områder bør således udforskes nærmere i specifikke fællesnordiske projekter.

Arbejdet med kvalitetsindikatorer for mund- og tandsundhed illustrerer, at de nordiske lande er ganske langt på dette område. Det påpeges imidlertid også, at der er behov for videreudvikling af kvalitetsindikatorer.

Arbejdet i Nordisk Ministerråds projektgrupper vedr. kvalitetsmåling illustrerer det moderne sundhedsvæsens begrænsede muligheder for at dokumentere kvaliteten af sundhedsvæsenets ydelser på vigtige områder.

Projektgruppen vedrørende patientoplevet kvalitet har fortsat et systematisk arbejde med at udvikle et fællesnordisk instrument til måling af patientoplevet kvalitet. Det bliver nu op til de nordiske lande at integrere instrumentet i de respektive sundhedsvæsener.

De nordiske lande har imidlertid som anført unikke muligheder for at udvikle dette område. Det foreliggende projektarbejde betragtes som et solidt grundlag herfor. I forlængelse heraf anbefales det:

- at der på områder, hvor der findes robuste data i relation til de valgte kvalitetsindikatorer, løbende offentliggøres kvalitetsdata i NOMESCO’s regi med henblik på at give borgere, politikere, sundhedspersonale og myndigheder indblik i kvaliteten af sundhedsvæsenets ydelser på tværs af de nordiske landegrænser

- at der i Nordisk Ministerråds regi etableres en arbejdsgruppe, der videreudvikler fællesnordiske kvalitetsindikatorer for psykiatri, samt sundhedsfremme og forebyggelse 
- at der etableres en arbejdsgruppe i Nordisk Ministerråds regi med henblik på at videreudvikle det fællesnordiske samarbejde om patientsikkerhed

- at der i Nordisk Ministerråds regi etableres en arbejdsgruppe mhp. at videreudvikle kvalitetsindikatorer for mund- og tandsundhed. 



\section{Summary}

The Nordic countries ${ }^{2}$ focus strongly on developing high-quality health services and on patient safety, and each country has launched wellfunctioning initiatives to document the quality of the health services provided.

The Nordic countries have unique opportunities to measure and monitor the performance of health services, since all the countries regularly gather data using health registries.

The Nordic Council of Ministers therefore launched four projects in 2007 to further develop indicators of the quality of health services with the aim of promoting dissemination, comparison and benchmarking between the Nordic countries.

The overall aim is to enable Nordic residents, politicians, health care personnel and health authorities to assess and compare the quality of health services across national borders in the Nordic countries. Another aim is to identify fields in which the Nordic countries can learn from one another with the aim of improving the quality of health services for the people who receive them: the patients.

Based on this, the Nordic Council of Ministers created four project groups to focus on the following topics from 2007 to 2010:

- generic and disease-specific indicators of health care quality

- indicators of the quality of oral health care

- indicators of patient safety

- indicators of quality as experienced by patients

\footnotetext{
${ }^{2}$ Denmark, Finland, iceland, Norway and Sweden and the autonomous territoriums og the faroe Islands and Greenland
} 
The project groups have closely collaborated with the Organisation for Economic Co-operation and Development (OECD) during the project period to ensure synergy with the international efforts to develop indicators of quality. The project work thus encompasses the OECD indicators of health care quality. This publication describes the work of the four project groups.

\section{Generic and disease-specific indicators of health care quality}

The project group on generic and disease-specific indicators of health care quality had the task of preparing, organizing and further developing proposed indicators that can comprise the basis for registering and monitoring the quality of health services in the Nordic countries. The quality indicators selected are assigned priority based on the criteria of frequency, severity, variation and economic aspects.

The indicators were selected with the aim of reflecting the organizational and professional quality of services. Similarly, the indicators were selected with the aim of being able to document structural factors, the process of providing services to patients and the health outcomes for patients. The project group decided to focus on the following areas:

- cancer: breast, lung, cervical and colon cancer and malignant melanoma

- cardiovascular diseases: myocardial infarction, ischaemic strokes and cerebral haemorrhage

- chronic diseases: diabetes and asthma

- pregnancy and birth

- children and adolescents

- health promotion and disease prevention

- general indicators that document the features of each patient's course of treatment and care

- mental health.

The project group selected numerous indicators for which it assessed that relevant data can be gathered now, and the report presents these data. 
In addition, the project group prepared and further developed potential indicators that it considers could be used in comparison and benchmarking between the Nordic countries in the coming years.

The report shows that data are available for many areas that enable comparison across the Nordic countries, whereas few data are available for other areas. This means that common Nordic quality indicators still need to be developed further in many areas.

For example, this applies to mental health, in which quality indicators need to be developed that can indicate a patient's course of treatment and care, and in health promotion and disease prevention, in which more data on living conditions and the standard of living are needed.

For the areas in which robust data are available, the working group recommends that the data be published regularly under the auspices of the Nordic Medico-Statistical Committee (NOMESCO).

\section{Indicators of the quality of oral health care}

The Nordic countries recognize the need for indicators of the quality of oral health care to monitor its quality and compare performance between the Nordic countries. The project arose because the Nordic countries lack common quality indicators despite efforts to develop the quality of oral care in the individual countries.

The remit of the working group stated that the project was to prepare a proposal and to develop common Nordic indicators of the quality of oral health care. These efforts were to be linked to the efforts of the OECD and the completed European Global Oral Health Indicators Development Project (EGOHID) project. The project was to last 3 years and started in 2007. Denmark, the Faroe Islands, Finland, Iceland, Norway and Sweden participated. Finland coordinated the project.

The project began by reviewing the relevant indicators for oral health in the Nordic countries and the principles behind them. The indicators were selected based on the European Community Health Indicators, the OECD recommendations, the EGOHID work and the specific interests of each Nordic country. 
The indicators were divided into four groups: structure indicators, process indicators, outcome indicators and potential quality indicators (indicators that need to be developed further).

The working group agreed on four structure indicators:

- the ratio between the number of inhabitants and the number of authorized oral health care providers younger than the standard retirement age

- the ratio between the number of inhabitants and the number of authorized oral health care providers younger than the standard retirement age who are currently in the labour force

- the ratio between the number of dentists younger than the standard retirement age and the total number of oral health care providers currently in the labour force

- the annual cost of oral health care per inhabitant.

The working group agreed on three process indicators:

- the percentage of the population receiving oral health care within the past year

- the frequency of toothbrushing (percentage of the population brushing more than once daily)

- the annual mean consumption of sugar-containing beverages per person

The working group agreed on five outcome indicators:

- the percentage of children and adolescents examined who had no caries

- the median number of decayed, missing and filled teeth (DMFT) among the children and adolescents examined

- the significant caries index (mean DMFT score for the one third of the population with the highest DMFT scores)

- the percentage of the population 65-74 years old who have no teeth the percentage of the population 65-74 years old who have at least 20 remaining teeth. 
The working group agreed on three potential quality indicators:

- the percentage of the population receiving oral health care regularly

- self-rated oral health

- self-rated chewing ability.

The requirement for including indicators was that data be available for them in at least three Nordic countries.

The lack of data for some of the outcome indicators illustrates the difficulty in obtaining uniform and current data on the quality of oral health care in the Nordic countries. Much effort has been made to define the indicators, and many of the data gathered can therefore be used for comparison and benchmarking, but further work is required to develop relevant quality indicators.

The working group has emphasized the importance of all Nordic countries striving to obtain data on the agreed indicators based on uniform methods, such as identical definitions and comparable age groups. More quality indicators for oral health care are needed in the future, and the working group agreed that this work would continue.

\section{Quality indicators for patient safety}

Patient safety has received considerable attention in the past decade. The results of many studies in several countries unanimously indicate that health care harms many patients unnecessarily. This includes diagnoses that are missed or made too late, surgical adverse events, adverse events in pharmaceutical management and poor hygiene that causes severe infections.

These studies have contributed to identifying risks and adverse events in health care and accelerate progress towards improving patient safety. In addition to minimizing the suffering adverse events cause patients and their families, improving patient safety is cost-effective. Harmful adverse events in health care result in extra days of hospital care, which increases costs and reduces accessibility. It also imposes substantial costs on society.

Health care is a complex high-risk activity, and improving patient safety requires efforts at all levels. Identifying and managing risk should be a standard procedure in health services. This requires a culture of safety that enables personnel to openly report and discuss adverse events so that measures 
are implemented to prevent them in the future. It should be easy to do the right thing and difficult to make errors. A high level of patient safety also requires that examinations, tests, treatments and nursing care be based on scientific evidence and proven experience.

A high level of patient safety is needed to maintain people's confidence in the quality of health care. Indicators that monitor the level of patient safety in health services therefore urgently need to be developed. Research and the development of knowledge on patient safety are in their infancy, and this field therefore lacks functioning structures and registries for gathering data and the knowledge and scientific evidence needed to develop solid indicators. The OECD and European Union have initiated efforts to develop patient safety indicators, and Nordic cooperation can contribute significantly to this.

\section{Nordic indicators of patients' experience in health services}

Patients' experiences and satisfaction are an important aspect of the quality of health services. One working group in the Nordic cooperation on indicators of the quality of health services therefore developed indicators of patients' experiences of the quality of health services.

The working group was asked to identify indicators and instruments to measure how patients experience quality. The mandate was to propose 6-12 potential indicators that can form the basis for registering and monitoring this field, to enable data to be compared across the Nordic countries.

National surveys of users of health services in the Nordic countries vary. The working group rapidly determined that no country wanted to replace its existing national surveys of patients' experiences. The working group therefore established that the Nordic indicators should be integrated as a supplement to the existing surveys in each country. The working group agreed on eight questions on experiences for adult somatic inpatients: six focus on relations with health care personnel, one on adverse events in health care and one on general satisfaction.

The working group identified standard procedures for translation, cognitive interviewing and pilot testing of the questions. The translations, cognitive interviews and pilot testing showed that this instrument worked well. 
The eight questions comprise the Nordic Patient Experiences Questionnaire (NORPEQ).

Norway included the NORPEQ in a nationwide survey in 2006. The aim was to get the other Nordic countries to include the NORPEQ in future national surveys after translation, cognitive interviewing and pilot testing in each country. Several practical barriers emerged associated with including the NORPEQ in other national surveys, including funding, national infrastructure and legislation.

The working group emphasizes the importance of embedding the inclusion of the NORPEQ in national surveys of patient experiences through explicit health policy decisions in each country and following this up in the coming years.

NORPEQ was designed for adult somatic inpatients, an important but small group of patients among the total patients in secondary and primary health care. The Norwegian Knowledge Centre for the Health Services and the secretariat of the working group in Norway have developed and tested 10 generic core questions that can be used across nine groups of patients, including patients being treated by mental health services and somatic outpatients. This instrument is now available for the other Nordic countries and may comprise potential Nordic indicators in the future.

The indicators based on an OECD project on the responsiveness of the health system and patient experiences are also potential future indicators in the Nordic project.

\section{Perspectives}

This report documents that the Nordic countries have great potential for measuring and monitoring the quality of health services, and relevant indicators of quality can be identified across the countries. Nevertheless, substantial effort is needed to ensure the quality of the data, including validity and generating data in many areas.

Several results that are available can thus not be used for appropriate comparisons and benchmarking but could more be used to question whether the quality of services actually differs. Considerable effort is thus required to ensure valid, updated data to enable real comparison and benchmarking 
between the Nordic countries. Similarly, potential quality indicators need to be developed dynamically.

The report shows that data that would enable the Nordic countries to be compared on certain important parameters are not available. Thus, data indicating the state of patient safety in the Nordic countries are not available. International efforts to develop quality indicators for patient safety have been initiated very recently, and the Nordic countries are expected to be able to contribute to this work.

In relation to mental health, the development of quality indicators that reflect patients' courses of care and treatment needs to be accelerated. This field has been poorly investigated internationally. The Nordic countries can contribute to developing useful quality indicators for mental health and for health promotion and disease prevention.

The efforts to develop quality indicators for oral health care illustrate that the Nordic countries have made great progress. Nevertheless, indicators of the quality of oral health and oral health care need to be developed further.

The work in the Nordic Council of Ministers working group on measuring the quality of health care illustrates the limited opportunities modern health systems have to document the quality of health services in important fields.

Nevertheless, the Nordic countries have unique opportunities to develop this field. The project work that has been carried out is considered a solid basis for this. The following measures are therefore recommended.

- In areas in which robust data are available for the selected quality indicators, data on the quality of health services should be regularly published under the auspices of NOMESCO with the aim of giving the public, politicians, health care personnel and public authorities insight into the quality of health services across the Nordic countries

- A working group should be established under the auspices of the Nordic Council of Ministers to further develop common Nordic quality indicators for mental health and for health promotion and disease prevention

- A working group should be established under the auspices of the Nordic Council of Ministers to further develop Nordic cooperation on patient safety 
- A working group should be established under the auspices of the Nordic Council of Ministers with the aim of further developing indicators for oral health and oral health care. 



\section{Tiivistelmä}

Pohjoismaissa kiinnitetään suurta huomiota laadun kehittämiseen ja potilasturvallisuuteen, ja kussakin maassa on tehty hyvin toimivia aloitteita terveydenhuollon tarjoamien palvelujen laadun seuraamiseksi.

Pohjoismailla on ainutlaatuiset mahdollisuudet palveluiden mittaamiseen ja valvomiseen, sillä maat keräävät jatkuvasti tietoja terveydenhuollon rekistereihin.

Tähän liittyen Pohjoismaiden ministerineuvosto pani vuonna 2007 toimeen neljä osahanketta, joiden tarkoituksena on kehittää edelleen laatua mittaavia indikaattoreita Pohjoismaiden välistä tietojenvälitystä, vertailua ja vertailututkimuksia varten.

Tärkeimpänä tavoitteena on antaa Pohjoismaiden kansalaisille, poliitikoille sekä terveydenhuollon henkilökunnalle ja viranomaisille mahdollisuus arvioida ja verrata terveydenhuollon tarjoamia palveluja eri Pohjoismaissa. Toinen tavoite on tunnistaa ne alueet, joilla Pohjoismaat voivat oppia toisiltaan terveydenhuollon tarjoamien palvelujen laadun kehittämi-sessä potilaiden kannalta, mikä on perimmäinen kysymys.

Tältä pohjalta Pohjoismaiden ministerineuvosto perusti neljä työryhmää, joiden tehtävänä oli keskittyä vuosina 2007-2010 seuraaviin osa-alueisiin:

- Geneeriset ja tautikohtaiset laatuindikaattorit

- Suun terveyden ja hammashuollon laatuindikaattorit

- Potilasturvallisuusindikaattorit

- Potilaan kokeman laadun indikaattorit.

Hankkeen yhteydessä on tehty tiivistä yhteistyötä OECD:n kanssa synergian varmistamiseksi kansainvälisten laatuindikaattorien työstämisessä, ja OECD:n laatuindikaattorit on sisällytetty hankkeen työhön. Seuraavassa on kuvattu näiden neljän projektiryhmän työtä. 


\section{Geneeriset ja tautikohtaiset laatuindikaattorit}

Geneerisiä ja tautikohtaisia laatuindikaattoreita selvittäneen työryhmän tehtävänä on ollut työstää, kartoittaa ja kehittää ehdotuksia indikaattoreiksi, jotka voisivat luoda perustan pohjoismaisten terveydenhuollon tarjoamien palvelujen laadun valvonnalle. Valitut indikaattorit on priorisoitu suhteessa esiintymistiheyteen, vakavuuteen, vaihteluun ja talouteen.

Indikaattorit on valittu siten, että ne heijastavat sekä organisatorista että terveydenhuollon laatua. Lisäksi indikaattorien valinnassa on huomioitu rakenteiden kuvaus, hoidon kulku (prosessi) sekä tulokset potilaan kannalta.

Työryhmä on keskittynyt seuraaviin alueisiin:

- Syöpäsairaudet (rintasyöpä, keuhkosyöpä, kohdunkaulan syöpä, paksu- ja peräsuolen syöpä sekä pahanlaatuinen melanooma)

- Sydän- ja verisuonitaudit (sydänveritulppa, aivoveritulppa ja aivoverenvuoto)

- Krooniset sairaudet (diabetes ja astma)

- Raskaus ja synnytys

- Lapset ja nuoret

- Terveyden edistäminen ja sairauksien ehkäisy

- Yleiset indikaattorit, jotka kuvaavat potilaan hoidon kulun osatekijöitä

- Mielenterveys.

Työryhmä on valinnut indikaattoreita, joihin arvioidaan voitavan ajantasaisesti kerätä raportissa esitettyjä oleellisia tietoja.

Lisäksi työryhmä on työstänyt ja kehittänyt mahdollisia indikaattoreita, joita arvioidaan tulevaisuudessa voitavan käyttää Pohjoismaiden välisissä arvioinneissa ja vertailututkimuksissa.

Raportti osoittaa, että monilta osa-alueilta voidaan hankkia tietoja, jotka mahdollistavat eri Pohjoismaiden vertailun, kun taas joiltakin osa-alueilta tietoja on saatavilla vain rajoitetusti. Näitä osa-alueita varten on siis edelleen tarvetta kehittää yhteispohjoismaisia laatuindikaattoreita.

Esimerkkeinä ovat mielenterveys, jonka osalta on tarvetta kehittää potilaitten hoidon kulkua terveydenhuollossa kuvaavia laatuindikaattoreita, sekä terveyden edistäminen ja sairauksien ehkäisy, joiden kohdalla on tarvetta saada enemmän tietoja elinoloista ja elintasosta. 
Niiltä osa-alueilta, joilta on saatavilla vankkaa tietoa, suositellaan tietojen julkistamista Nomeskossa.

\section{Suun terveyden ja hammashuollon laatuindikaattorit}

Pohjoismaissa tunnistetaan suun terveyden ja hammashuollon laatuindikaattorien tarve, jotta hammashuollon laatua voitaisiin seurata ja vertailla eri Pohjoismaiden välillä. Hankkeen taustalla on yhteispohjoismaisten laatuindikaattorien puute, joskin hammashoidon laadunvalvonnassa maiden välillä on tehty yhteistyötä.

Työryhmän toimeksiantoon kuului valmistella ehdotus ja esittää yhteispohjoismaiset suun terveyden ja hammashuollon laatuindikaattorit. Työ tuli yhdistää OECD:n työskentelyyn ja sitä edeltäneeseen EGOHID-hankkeeseen (European Global Oral Health Indicators Development Project). Toimeksiannon pituudeksi määrättiin kolme vuotta ja hanke aloitettiin vuonna 2007. Hankkeeseen osallistuivat Färsaaret, Islanti, Norja, Ruotsi, Suomi ja Tanska. Suomi toimi hankkeen koordinaattorina.

Hanke aloitettiin käymällä läpi olemassaolevat pohjoismaiset hammashuollon indikaattorit ja niiden taustalla olevat filosofiat. Indikaattorit valittiin ECHI:n (European Community Health Indicators) ja OECD:n suositusten sekä EGOHID-työn ja Pohjoismaiden erityisintressien perusteella.

Indikaattorit jaettiin neljään esille otettavaan ryhmään: rakenteelliset, prosessi-, tulos- ja laatuindikaattorit.

Työryhmä sopi neljä rakenneindikaattoria: 1 . asukkaiden lukumäärä laillistettujen, alle eläkeikäisten hammashuollon työntekijöiden määrään nähden, 2. asukkaiden lukumäärä alle eläkeikäisten, ammatissa toimivien hammashuollon työntekijöiden määrään nähden, 3. alle eläkeikäisten hammaslääkärien määrä hammashuollon työntekijöiden määrään nähden, 4. hammashuollon kulut asukasta kohden; kolme prosessi-indikaattoria: 1 . viimeisen vuoden aikana hammashoidossa käyneiden asukkaiden prosentuaalinen lukumäärä väestöstä, 2. hampaidenharjaustiheys (useammin kuin kerran päivässä), 3. sokeripitoisten virvoitusjuomien kulutus; viisi tulosindikaattoria: 1. karieksettomien lasten ja nuorten osuus tutkituista (\%), 2. tutkittujen lasten ja nuorten DMFT-keskiarvo (Decayed, Missing and Filled Teeth), 3. SiC-indeksi (Significant Caries Index), 4. hampaattomien 65-74vuotiaiden osuus väestöstä (\%), 5. niiden 65-74-vuotiaiden, joilla on vähin- 
tään 20 prosenttia hampaista jäljellä, osuus väestöstä (\%) ja kolme mahdollista laatuindikaattoria: 1. säännöllisesti hammaslääkärissä käyvien asukkaiden osuus väestöstä, 2. itse koettu hammasterveys (suun terveys), 3. itse koettu purentakyky. Edellytyksenä indikaattoreille oli, että tietoja oli oltava saatavilla vähintään kolmesta Pohjoismaasta.

Joitakin tulosindikaattoreita koskeva tiedonpuute kuvastaa yhtenäisten ja ajankohtaisten hammashuollon laatutietojen saannin vaikeuden Pohjoismaissa. Indikaattorien määrittämiseksi on tehty paljon työtä, joten suurta määrää kerätyistä tiedoista voidaan käyttää vertailuihin ja vertailututkimuksiin, mutta merkityksellisten laatuindikaattorien kehittämiseksi on tehtävä edelleen työtä.

Työryhmä on painottanut kaikkien Pohjoismaiden yhteistyötä vertailukelpoisten indikaattorien saamiseksi käyttäen samoja menetelmiä, esim. yhdenmukaisilla määritelmillä ja käyttämällä vertailukelpoisten ikäryhmien tietoja. Tulevaisuudessa tarvitaan useampia hammashoidon laatuindikaattoreita ja työryhmä oli yhtä mieltä työn jatkamisesta.

\section{Potilasturvallisuuden laatuindikaattorit}

Potilasturvallisuuteen on kiinnitetty suurta huomiota viimeisen kymmenen vuoden aikana. Useissa maissa tehdyt lukuisat tutkimukset osoittavat yhdenmukaisesti, että monet potilaat vahingoittuvat tarpeettomasti hoidon aikana. Syynä voivat olla väärät tai liian myöhään tehdyt diagnoosit, väärät toimenpiteet, väärä lääkkeidenhallinta tai puutteellisesta hygieniasta aiheutuvat infektiot.

Tutkimusten myötä on alettu kiinnittää huomiota hoidon riskeihin ja puutteisiin, ja ne ovat nopeuttaneet potilasturvallisuuden parantamista. Potilaille ja heidän läheisilleen aiheutuneiden kärsimysten vähentämisen lisäksi potilasturvallisuuden parantaminen kannattaa myös taloudellisesti. Terveydenhuollossa tapahtuneet vahingoittumiset pidentävät sairaaloiden hoitoaikoja, mikä lisää kustannuksia ja heikentää saatavuutta. Yhteiskunnalle aiheutuu lisäksi huomattavia kustannuksia.

Terveydenhuolto on monimuotoinen ja riskialtis toimiala, joten potilasturvan parantaminen edellyttää panostusta kaikilla tasoilla. Riskien huomioimisen ja käsittelyn on oltava luonnollinen osa hoidon kulkua. Siihen tarvitaan turvallisuuskulttuuria, joka mahdollistaa henkilökunnan avoimen rapor- 
toinnin ja keskustelun havaituista virheistä, jotta voidaan ryhtyä toimenpiteisiin vastaavien virheiden estämiseksi. Oikein toimimisen on oltava helppoa ja väärin toimimisen vaikeaa. Hyvä potilasturva edellyttää myös sitä, että tutkimukset, hoito ja huolenpito perustuvat tieteeseen ja tutkittuun kokemukseen.

Hyvä potilasturva on edellytys sille, että kansalaiset säilyttävät luottamuksensa terveydenhuoltoon. Tämän vuoksi on kiireellisesti kehitettävä hoidonaikaisen potilasturvallisuuden tasoa ilmaisevia indikaattoreita. Potilasturvallisuuden tutkiminen ja tietojen hankinta on aloitettu vastikään. Siksi tälle alueelle tarvitaan toimivia rakenteita ja tietorekistereitä sekä hyvin perusteltujen indikaattorien saamiseksi tarvittavaa tietoa ja tieteellistä dokumentointia. Potilasturvallisuusindikaattorien kehittäminen on aloitettu OECD:ssä ja EU:ssa. Pohjoismainen yhteistyö voi antaa tähän työhön arvokkaan panoksensa.

\section{Pohjoismaiset terveydenhuollon potilaskokemusten laatumittaukset}

Potilaiden kokemukset ja tyytyväisyys ovat tärkeä osa terveydenhuollon toimintaa. Siksi yksi pohjoismaisen indikaattoriyhteistyön työryhmistä on työstänyt potilaiden kokeman laadun indikaattoreita.

Työryhmän tehtävänä oli kehittää potilaiden kokemaa laatua ilmentäviä indikaattoreita ja mittausmenetelmiä. Tehtävänä oli ehdottaa 6-12 mahdollista indikaattoria, jotka voisivat muodostaa perustan rekisteröimiselle ja valvonnalle sekä Pohjoismaiden väliselle tietojen vertailuille.

Kansalliset käyttäjätutkimukset ovat jonkin verran erilaisia eri Pohjoismaissa. Kävi pian selväksi, ettei yksikään maa ollut halukas korvaamaan olemassa olevia potilastutkimuksiaan. Siksi työryhmä otti lähtökohdakseen pohjoismaisten indikaattorien yhdistämisen olemassa oleviin tutkimuksiin. Työryhmä sopi kahdeksasta somaattisen vuodeosastohoidon aikuispotilaille esitettävästä potilaskokemukseen liittyvästä kysymystä. Kuusi kysymyksistä käsitteli suhdetta hoitohenkilökuntaan, yksi hoitovirheitä ja yksi yleistä terveydentilaa.

Työryhmä määritteli standardimenetelmät käännöksille, kognitiivisille haastatteluille ja pilottitutkimuksen kysymyksille. Käännökset, kognitiiviset haastattelut ja pilottitestaus osoittavat, että väline toimii hyvin. Kahdeksasta 
kysymyksestä käytetään nimitystä NORPEQ (Nordic Patient Experiences Questionnaire).

Norja sisällytti NORPEQ-kysymykset kansalliseen tutkimukseen vuonna 2006. Tarkoituksena oli, että NORPEQ-kysymyksiä olisi käytetty eri Pohjoismaiden kansallisissa tutkimuksissa niiden kääntämisen, kognitiivisten haastattelujen ja pilottitutkimuksen jälkeen. Käytännössä osoittautui kuitenkin, että NORPEQ-kysymysten mukaan ottamiselle kansallisiin tutkimuksiin oli useita rahoitukseen, kansalliseen infrastruktuuriin ja lainsäädäntöön liittyviä esteitä.

Työryhmä painottaa, että on tärkeää sisällyttää NORPEQ-kysymykset kussakin maissa kansallisiin potilastutkimuksiin selvästi ilmaistujen terveyspoliittisten päätösten myötä ja että tämän toteutumista seurataan lähivuosina.

NORPEQ-kysymykset on tarkoitettu aikuisille somaattisen vuodeosastohoidon potilaille, joka on tärkeä, mutta rajattu potilasryhmä tutkittaessa erikoissairaanhoitoa ja perusterveydenhuoltoa yhdessä. Norjan kansallinen terveyspalvelujen tietokeskus on kehittänyt ja testannut 10 geneeristä avainkysymystä, joita voidaan käyttää yhdeksässä potilasryhmässä psykiatria ja somaattisten alojen polikliininen työ mukaan luettuina. Tämä työkalu on muiden Pohjoismaiden käytettävissä ja pitkällä tähtäimellä se voi olla mahdollinen indikaattori.

Myös OECD:n hankkeet ovat tulevaisuudessa mahdollisia pohjoismaisten projektien indikaattoreita.

\section{Näkökulmia}

Tämä raportti osoittaa, että terveydenhuollon palvelujen mittaamiseen ja seurantaan Pohjoismaissa on hyvät mahdollisuudet. Yhteenvetona voidaan sanoa, että oleelliset laatuindikaattorit on mahdollista tunnistaa kaikissa Pohjoismaissa. Tietojen laadun varmistamiseen ja luotettavien tietojen hankintaan useilta alueilta on kuitenkin kiinnitettävä suurta huomiota.

Osaa saatavilla olevista tuloksista ei todennäköisesti voida käyttää todenmukaisiin vertailuihin ja vertailututkimuksiin, vaan lähinnä kysymyksenasetteluun siitä, kuinka laajalti todellisia eroja palvelujen laadussa on. Siksi on tarpeen panostaa huomattavasti pätevien ja ajantasaisten tietojen hankintaan, jotta Pohjoismaiden välillä voitaisiin tehdä oikeansuuntaisia 
vertailuja ja vertailututkimuksia. Lisäksi on tarvetta kehittää vahvasti uusia mahdollisia laatuindikaattoreita.

Lisäksi on käynyt ilmi, että joiltakin tärkeiltä osa-alueilta ei ole mahdollista saada tietoja, joita voitaisiin käyttää Pohjoismaiden väliseen vertailuun. Pohjoismaiden potilasturvallisuuteen liittyviä tietoja ei myöskään ole ollut saatavilla. Kansainvälinen työ potilasturvallisuuden laatuindikaattorien laatimiseksi on juuri aloitettu, ja Pohjoismaiden odotetaan osallistuvan tähän työhön.

Mielenterveyden osalta on tarvetta kehittää terveydenhuollon hoidon kulkua kuvaavia laatuindikaattoreita. Kansainvälisesti tämä osa-alue on kuvattu heikosti. Arvion mukaan Pohjoismaat voivat osallistua laadukkaiden indikaattorien kehittämiseen tällä osa-alueella, samoin kuin terveyden edistämiseen ja sairauksien ehkäisyyn.

Suun terveyden ja hammashuollon laatuindikaattoreiden tarkastelu osoittaa, että Pohjoismaat ovat tällä osa-alueella varsin pitkällä. On kuitenkin huomautettava, että tämän osa-alueen laatuindikaattoreita on tarpeen kehittää edelleen.

Pohjoismaiden ministerineuvoston työryhmien laadun mittaamisen tarkastelu osoittaa, että nykyaikaisella terveydenhuollolla on rajalliset mahdollisuudet dokumentoida tarjoamiensa palveluiden laatua tärkeillä osa-alueilla.

Pohjoismailla on kuvauksen mukaisesti kuitenkin ainutlaatuiset mahdollisuudet kehittää tätä osa-aluetta, ja tämän projektityön katsotaan muodostavan kehittämiselle vakaan perustan. Tämän työn jatkoksi suositellaan, että

- Nomesko julkaisee laatutiedot niiltä osa-alueilta, joilta on olemassa valittuihin laatuindikaattoreihin liittyvää vankkaa tietoa, jotta kansalaiset, poliitikot, terveydenhuollon henkilökunta ja viranomaiset saavat kuvan terveydenhuollon tarjoamien palvelujen laadusta eri Pohjoismaissa

- Pohjoismaiden ministerineuvosto muodostaa työryhmän, joka kehittää edelleen mielenterveyteen sekä terveyden edistämiseen ja sairauksien ehkäisyyn liittyviä yhteispohjoismaisia laatuindikaattoreita

- Pohjoismaiden ministerineuvosto muodostaa työryhmän, joka kehittää edelleen pohjoismaista yhteistyötä potilasturvallisuuden alalla

- Pohjoismaiden ministerineuvosto muodostaa työryhmän, joka kehittää edelleen suun terveyden ja hammashuollon laatuindikaattoreita. 



\section{Samandráttur}

Dygdarmenning og sjúklingatrygd eru í brennidepli í Norðurlondum, og í ymsu londunum eru sett í verk tiltøk, sum virka væl, at lýsa dygdina av veitingunum í heilsuverkinum.

Norðurlond hava frálíkar møguleikar at máta og hyggja eftir veitingunum, av tí at øll londini støðugt savna upplýsingartilfar í heilsuskrásetingum.Sum framhald av hesum setti Norðurlendska ráðharraráðið í 2007 í verk fýra partsverkætlanir, hvørs endamál vóru at menna dygdarábendingar við atliti at bera fram kunning, samanbering og benchmarking (skipaðar samanberingar við sínámillum kunning um royndir og betring sum mál) millum Norðurlond.

Yvirskipaða endamálið er at geva norðurlendskum borgarum, politikarum, heilsustarvsfólki og heilsumyndugleikum møguleika at meta um og bera saman veitingarnar í heilsuverkinum tvørtur um norðurlendsk landamørk. Eitt annað endamál er at eyðmerkja øki, har ið Norðurlond kunnu læra hvørt av øðrum við tí í hyggju at bøta um góðskuna á veitingum í heilsuverkinum fyri tey, ið tað snýr seg um, nevnliga sjúklingarnar.

Við støði í hesum setti Norðurlendska ráðharraráðið fýra verkætlanarbólkar, sum í tíðarskeiðinum 2007-2010 skuldu leggja dent á:

- Heildar- og sjúkuserkendar dygdarábendingar

- Dygdarábendingar fyri munn- og tannheilsurøkt

- Sjúklingatrygdarábendingar

- Dygdarábendingar fyri sjúklinganøgdsemi.

Í verkætlanartíðarskeiðinum hevur verið tætt samstarv við OECD til tess at tryggja samvirki til alheimsvirksemi við dygdarábendingum. Dygdarábendingar hjá OECD eru sostatt sum heild taldar uppí hetta arbeiði.

Niðanfyri er arbeiðið hjá teimum fýra verkætlanarbólkunum lýst. 


\section{Heildar- og sjúkuserkendar dygdarábendingar}

Verkætlanarbólkurin viðvíkjandi heildar- og sjúkuserkendum dygdarábendingum hevur havt sum uppgávu at greiða úr hondum, kortleggja og menna uppskot til ábendingar, ið kunnu gerast støði undir hesum at skráseta og ansa eftir dygdini í veitingum heilsuverksins í Norðurlondum. Valdu dygdarábendingarnar eru raðfestar í mun til: tíðleika, álvarsemi, margfeldi og kostnað.

Ábendingarnar eru valdar við atliti at hesum at kunna endurspegla bæði fyriskipanarligu og heilsufakligu dygdina. Somuleiðis eru ábendingarnar valdar til at kunna lýsa bygnaðarlig viðurskifti, sjúklingagongdina og úrslitið fyri sjúklingin.

Verkætlanarbólkurin hevur valt at leggja dent á hesi øki:

- Krabbamein (Bróstkrabbi, lungnakrabbi, lívmóðurhálskrabbi, krabbi á langa og baktarmi, móðurmerkjakrabbi)

- Hjarta/æðrasjúkur (Blóðtøppur í hjarta, blóðtøppur í heila og heilabløðing)

- Tráar sjúkur (Sukursjúka og astma)

- Viðgongutíð og føðing

- Børn og ung

- Heilsufremjan og fyribyrging

- Heildarábendingar, ið lýsa partar av gongdini hjá einum og hvørjum sjúklingi

- Sálarlig heilsa.

Verkætlanarbólkurin hevur valt eina røð av ábendingum, har ið mett hevur verið, at tað í løtuni ber til at fáa til vega dáta, og tær eru at síggja í frágreiðingini.

Umframt hetta hevur bólkurin greitt úr hondum og ment møguligar ábendingar, ið vera hildnar at kunna nýtast til skipaðar samanberingar og benchmarking millum Norðurlond í komandi árum.

Frágreiðingin sýnir, at tað á eini røð av økjum ber til at fáa til vega dáta, so til ber at bera saman støðuna millum Norðurlond, meðan dáta bert eru til taks í minni mun á øðrum økjum sum er. Hetta ber í sær, at tað framvegis er tørvur á at menna felags norðurlendskar dygdarábendingar á fleiri økjum. 
Hetta er til dømis so, tá ið hugsað verður um sálarliga heilsu, har tørvur er á at menna dygdarábendingar, íð lýsa gongdina hjá sjúklingunum í heilsuverkinum, og fyribyrging og heilsufremjan, har ið tørvur er á fleiri dátum viðvíkjandi livikorum og lívskrøvum.

Á teimum økjum, har ið haldgóð dáta eru tøk, verður mælt til, at dáta regluliga verða almannakunngjørd í virkisøki NOMESCO’s.

\section{Dygdarábendingar fyri munn- og tannheilsutænastu}

Norðurlond ásanna tørvin á dygdarábendingum fyri tannheilsutænastuna, til tess at ein skal kunna meta um tannheilsurøktina og bera saman avrikini millum Norðurlond. Verkætlanin kom í, av tí at tørvur var á dygdarábendingum, ið kundu samanberast í londunum, tó at ávíst dygdarmetingararbeiði í sambandi við tannheilsurøkt fer fram í einstøku londunum.

Av setninginum fyri verkætlanarbólkin sást, at verkætlanin skuldi fyrireika eitt uppskot og fáa til vega norðurlendskar dygdarábendingar fyri tannheilsurøkt, ið kundu samanberast. Arbeiðið skuldi bindast saman við OECD og EGOHID-verkætlanina. Bólkurin skuldi arbeiða í trý ár, og verkætlanin byrjaði í 2007. Danmark, Føroyar, Finnland, Ísland, Noreg og Svøríki hava luttikið í verkætlanini. Finnland samskipaði verkætlanina.

Verkætlanin byrjaði við eini gjøgnumgongd av ábendingum, ið vóru at finna fyri tannheilsu í Norðurlondum, og orsøkunum til, at tær vóru fingnar til vega. Ábendingarnar vóru valdar í samsvari við ECHI-tilmælini (European Community Health Indicators), OECD-timælini, EGOHID-arbeiðið (European Global Oral Health Indicators Development Projekt) og í mun til serligu áhugamálini hjá einstøku Norðurlondunum.

Ábendingarnar vóru býttar í fýra bólkar: bygnaðarábendingar, ábendingar viðvíkjandi mannagongdum, úrslitsábendingar og møguligar dygdarábendingar -ábendingar, ið skulu fáast til vega.

Bólkurin samdist um fýra bygnaðarábendingar: 1. tal á íbúgvum fyri hvørt løggilt tannheilsustarvsfólk undir eftirlønaraldur, 2. tal á íbúgvum fyri hvørt tannheilsustarvsfólk undir eftirlønaraldur, 3. tal á tannlæknum undir eftirlønaraldur fyri hvørt tannheilsustarvsfólk, 4. tannheilsurøktarkostnaður fyri hvønn íbúgva, tríggjar ábendingar viðvíkjandi mannagongdum: 1. partur (\%) av fólkinum, ið hevur vitjað tannheilsutænastuna í eitt ár, 2. tíðleikin at busta tenn (meira enn eina ferð um dagin), 3. nýtsla av sukurdrykkjum, 
fimm úrslitsábendingar: 1. partur av kannaðum bør-num og ungum við ongum brendum tonnum, 2. miðalvirði fyri DMFT (Decayed, missing and filled teeth) hjá kannaðum børnum og ungum, 3. SiC-index (Significant Caries Index), partur (\%) av tannleysum 65-74-ára gomlum, 5. partur (\%) av 65-74-ára gomlum, ið hava í minsta lagi 20 varðveittar tenn í munninum, og tríggjar møguligar dygdarábendingar: 1. partur av fólkinum, ið vitjar tannheilsutænastuna regluliga, 2. sjálvmett tannheilsa (munnheilsa), 3. sjálvmettur tyggiførleiki. Kravið, ið sett var til, at ábendingarnar skuldu takast við, var, at dáta vóru til taks fyri tær í minst trimum Norðurlondum.

Trotið á dáta fyri nøkrum av úrslitsábendingunum sýna trupulleikan at fáa til vega tíðarbær dygdardáta, sum kunnu berast saman í tannheilsutænastuni í Norðurlondum. Nógv arbeiði er gjørt at allýsa ábendingarnar, og tí kann størri parturin av dátum, ið eru fingin til vega, nýtast til samanberingar og benchmarking, men tørvur er á enn meira arbeiði til tess at menna týðandi dygdarábendingar.

Verkætlanarbólkurin leggur dent á týdningin av, at øll Norðurlond virka fyri at fáa til vega dáta um ábendingar, ið semja er um eftir sama leisti, eitt nú einsljóðandi allýsingar og aldursbólkar, ið kunnu sammetast. Í framtíðini er tørvur á fleiri dygdarábendingum fyri tannheilsurøktina, og semja er í bólkinum um, at arbeiðið eigur at halda fram.

\section{Sjúklingatrygdarábendingar}

Seinastu tíggju árini er hugtakið sjúklingatrygd í stóran mun komið fram. Úrslitini av nógvum kanningum í fleiri ymiskum londum benda øll á, at mangir sjúklingar verða skaddir óneyðugt í heilsuverkinum. Tað kann snúgva seg um skeivar ella ov seint staðfestar sjúkuavgerðir, skeiv inntriv, skeiva handfaring av heilivági og tvørrandi reinføri, ið hevur við sær svárar ígerðir.

Kanningarnar hava givið íkast til tess at gera vart við vandar og brek í heilsuverkinum og stuðla menningini av eini størri sjúklingatrygd. Umframt at minka um líðing, ið hesir skeivleikar elva sjúklingum og avvarðandi, so loysir tað seg eisini fíggjarliga at bøta um sjúklingartrygdina. Skeivleikar elvdir av heilsuverkinum hava við sær longda tíð á sjúkrahúsi, sum ber í sær øktan kostnað. Hartil kemur annar munandi kostnaður fyri samfelagið. 
Heilsuverkið er eitt fjøltáttað hávandavirki, og tørvur er á virksemi á øllum stigum til tess at bøta um sjúklingatrygdina. At gera vart við og handfara vandar eigur at gerast ein náttúrligur partur av arbeiðsháttinum í verkinum. Hetta krevur eina trygdarmentan, sum loyvir, at starvsfólk geva frágreiðing um og kjakast um tey mistøk, sum henda, so at atgerðir verða framdar til tess at forða fyri líkum mistøkum. Tað eigur at vera lætt at gera beint, og tað eigur at vera trupult at gera mistøk. Høg sjúklingatrygd hevur sum fyritreyt eisini, at kanningar, viðgerðir og røkt eru grundað á vísindi og væl grundaðar royndir.

Høg sjúklingatrygd er ein fyritreyt fyri at varðveita álit borgaranna á heilsuverkið.Tí er týdningarmikið at menna ábendingar, ið lýsa støðið viðvíkjandi sjúklingatrygd í verkinum. Gransking og vitanaruppbygging kring økið sjúklingatrygd eru nýliga byrjað, og økinum tørvar tí væl virkandi bygnaðir og skráir fyri dátuinnsavning umframt kunnleika og skjalprógv, ið krevst til tess at fáa til vega væl grundaðar ábendingar. Arbeiðið at menna sjúklingatrygdarábendingar er byrjað í OECD og EU, og norðurlendska samstarvið kann her verða eitt virðismikið íkast.

\section{Dygdarábendingar fyri sjúklinganøgdsemi}

Royndir sjúklinga og nøgdsemi eru ein týðandi partur, tá ið støða skal takast til dygdina í heilsuverkinum. Ein av verkætlanarbólkunum í norðurlendska ábendingarsamstarvinum hevur tí arbeitt við ábendingum fyri sjúk-linganøgdsemi.

Uppgávan hjá bólkinum var at fáa til vega ábendingar og mátiamboð til tess at endurspegla sjúklinganøgdsemi. Setningurin var at skjóta upp 6-12 møguligar ábendingar, ið kunnu gerast grundarlag fyri skráseting og eftirliti innan økið við atliti at tí at bera saman dátur millum Norðurlond.

Brúkarakanningar í Norðurlondum eru nakað ymiskar. Tíðliga gjørdist greitt, at eingi av londunum vildu broyta verandi sjúklinganøgdsemiskanningarnar. Sostatt gjørdist niðurstøðan hjá bólkinum, at norðurlendsku ábendingarnar skuldu lagast til sum ískoyti í verandi kanningum hjá einstøku londunum.

Bólkurin samdist um átta sjúklinganøgdsemisspurningar fyri vaksnar sjúk-lingar á samdøgursomatiskum sjúkrahúsum, og av hesum snúgva seks seg um samskifti við heilsustarvsfólk, ein um skeiva viðgerð og ein um nøgdsemi sum heild. Bólkurin gjørdi mynsturmannagongdir fyri umseting, kog- 
nitivar samrøður og undankanningar av spurningunum. Umsetingarnar, kognitivu samrøðurnar og undankanningar sýna, at amboðið riggar væl. Teir átta spurningarnir bera heitið NORPEQ (NORdic Patient Experiences Questionnaire).

Noreg skoytti NORPEQ upp í eina landskanning í 2006. Endamálið var, at hini londini skuldu skoyta NORPEQ uppí í komandi landskanningar eftir at tilfarið var týtt, eftir kognitivar samrøður og undankanningar í einstøku londunum. Royndirnar sýndu, at fleiri forðingar vóru í sambandi við at skoyta NORPEQ upp í landskanningar í hinum londunum, bæði tá ið talan var um fígging, undirstøðukervi og lógarverk.

Bólkurin leggur dent á týdningin av, at NORPEQ sum uppískoyti til sjúklinganøgdsemiskanningarnar verður grundfest gjøgnum skilligar heilsupolitiskar avgerðir í teimum einstøku londunum, og at hetta verður lýst í árunum, sum koma.

NORPEQ er lagað til vaksnar samdøgursomatiskar sjúklingar, ið eru ein týðandi, men avmarkaður bólkur av sjúklingum, tá ið hugt verður at serlæknaog primerheilsutænstuni undir einum. Tjóðarbundni vitanarmiðdepilin fyri heilsutænastu og avgreiðsludeildin í Noregi hava ment og roynt 10 heildarkjarnuspurningar, ið kunnu nýtast til níggju sjúklingabólkar, her uppií viðvíkjandi sálarsjúkum og útistovusomatikki. Hetta amboð er nú atkomandi hjá øðrum Norðurlondum og kann sum frá líður koma at gerast til møguligar norðurlendskar ábendingar. Ábendingar grundaðar á OECD verkætlanir eru somuleiðis møguligar ábendingar í norðurlendsku verkætlanini í komandi tíðum.

\section{Framtíðarmøguleikar}

Hendan frágreiðing skjalprógvar, at stórir menningarmøguleikar eru fyri máting og eftiransing í sambandi við veitingar heilsuverksins í Norðurlondum, og tann niðurstøðan kann verða gjørd, at til ber at eyðmerkja týðandi dygdarábendingar tvørtur um landamørk. Tørvur er tí á at nýta týðandi orku til tess at tryggja dátudygd, her uppií neyvleika og útvegan av dáta á fleiri økjum.

Ein partur av teimum dátum, ið eru tøkar, kunnu sostatt neyvan nýtast til álítandi samanberingar og benchmarking, men heldur til at seta spurningar um, í hvønn mun tað í veruleikanum eru sannir munir í dygdini á veitingunum. Tørvur er tí á týðandi virksemi til tess at tryggja neyv og tíðarsonn dáta 
við atliti at álítandi samanbering og benchmarking í Norðurlondum. Somuleiðis er tørvur á ídnari menning av møguligum dygdarábendingum.

Somuleiðis er greitt, at ikki ber til á týðandi økjum at fáa til vega dátur, ið gera tað møguligt at fáa í lag samanberingar í Norðurlondum, eitt nú við atliti at hesum at lýsa sjúklingatrygd. Í alheimshøpi er arbeiðið at menna dygdarábendingar á hesum øki júst byrjað, og vánir eru fyri, at Norðurlond kunnu geva íkast til hesa menning.

Í mun til sálarliga heilsu er tørvur á í størri mun at menna dygdarábendingar, ið lýsa sjúklingagongdir í heilsuverkinum. Í alheimshøpi er hetta økið bert lýst í lítlan mun. Mett verður, at Norðurlond kunnu geva íkast til menning av haldgóðum dygdarábendingum bæði á hesum øki, og tá ið viðvíkur fyribyrging og heilsufremjan.

Virksemið við dygdarábendingum fyri munn- og tannheilsu lýsir, at Norðurlond eru komin rættiliga langt áleiðis á hesum øki. Dentur verður tó lagdur á, at tørvur er á at menna enn meira dygdarábendingar á hesum øki.

Arbeiðið í verkætlanarbólkunum í Norðurlendska ráðharraráðnum viðvíkjandi dygdarmáting lýsir avmarkaðu møguleikarnar í nýmótans heilsuverkinum at skjalprógva dygdina í veitingum heilsuverksins á týðandi økjum.

Norðurlond hava tó, sum áður nevnt, serligar møguleikar at menna hetta økið. Verkætlanin verður mett sum eitt haldgott grundarlag fyri hesum. Í framhaldi av hesum verður mælt til

- at tað á økjum, har ið haldgóð dáta eru til taks í mun til kosnu dygdarábendingarnar, verða almannakunngjørd dygdardáta í virkisøki NOMESKO’s við tí endamáli at geva borgarum, politikarum, heilsusstarvsfólki og myndugleikum innlit í dygdina á veitingum heilsuverksins tvørtur um norðurlendsk landamørk

- at settur verður ein arbeiðsbólkur í virkisøki Norðurlendska ráðharraráðsins, ið mennir enn meira felags norðurlendskar dygdarábendingar fyri sálarliga heilsu, fyribyrging og heilsufremjan

- at ein arbeiðsbólkur verður settur í virkisøki Norðurlendska ráðharraráðsins við atliti at hesum at menna felags norðurlendska samstarvið um sjúklingatrygd

- at tað í virkisøki Norðurlendska ráðharraráðsins verður settur ein arbeiðsbólkur at menna dyrdarábendingar fyri munn- og tannheilsu. 



\section{Naalisagaq}

Nunani Avannarlerni sillimanikkut sullissinerullu pitsaassusaanik qulakkeerinninniarluni ineriartortitsisoqarpoq, nunallu ataasiakkaat peqqinnissaqarfiisa sullissinerisa pitsaassusaat pillugu ersersitsisussanik ingerlalluartunillu suliniuteqartoqarpoq.

Peqqissutsimut tunngatillugu nalunaarsuivinnut katersisarnertik pissutigalugu, sullissinerup nakkutigalugulu naammassisaasa naliliiviginissaannut paasissutissanik pissarsinissamut Nunat Avannarliit periarfissarissaarput.

Tamatumunnga tapiliullugu pitsaassutsimik naliliisinnaanissamut paasissutisseeqatigiinnissaminnut, assersuussisinnaanissaminnut unammillersinnaassuseqarnerminnullu takussutissiissutaasinnaasunik ineriartortitsinissamik siunertalinnik, suliniutinik immikkoortunik 4-nik Nunani Avannarlerni Ministerit Siunnersuisoqatigiivi 2007-mi aallartitsipput.

Peqqinnissaqarfimmiit sullinneqarnerup Nunat Avannarliit killeqarfii pitarlugit assersuullugillu naliliivigisinnaanissaannut, Nunani Avannarlerni innuttaasut, politikerit, peqqinnissamik sullissisut, peqqinnissaqarfimmilu pisortat periarfissinnissaat anguniakkat pingaarnersaraat. Nunat Avannarliit iluminni peqqinnissakkut sullissinermi qitiullutik inissisimasut, tassalu napparsimasut, sullinnerisa pitsaanerulersinnissaa anguniarlugu, ilinniarfigeqatigiissinnaanerup periarfissinnissaa siunniussattaaq ilagaat.

Tamakku tunngavigalugit Nunat Avannarliit Ministeriisa Siunnersuisoqatigiivi, suliniuteqartussanik immikkoortunik 4-nik pilersitsipput, taakkulu 2007-imiit 2010-p tungaanut makkuninnga sammisaqassapput:

- Pissutsinut nalinginnaasunut nappaatinullu aalajangersimasunut tunngatillugu pitsaassutsimik naliliinermi uuttuutissat

- Qarnup kigutillu paarinissaannut pitsaassutsimik naliliinermi uuttuutissat 
- Isumannaatsumik napparsimasut sullinneqarnissaat pillugu pitsaassutsimik naliliinermi uuttuutissat

- Napparsimasut sullinneqarnerup pitsaassusaanik misigisaat tunngavigalugit pitsaassutsimik naliliinermi uuttuutissat.

Nunarsuaq tamakkerlugu pitsaassutsimik naliliinermi uuttuutissanik suliaqarnerup pissarsiaqaataanissaa qulakkeerniarlugu, suliniummik ingerlatsinerup nalaani OECD qanimut suleqatigineqarpoq. Taamaasillutik OECD-p pitsaassutsimik naliliinermi uuttuutai suliami matumani ilaatinneqarput. Suliniuteqartut sisamaasut suliaat ataani allaaserineqarput.

\section{Pissutsinut nalinginnaasunut nappaatinullu aalajangersimasunut tunngatillugu pitsaassutsimik naliliinermi uuttuutissat}

Nunani Avannarlerni peqqinnissaqarfiit sullissinerisa nalunaarsorlugillu nakkutigineqarnissaannut tunngavissanik, pissutsinut nalinginnaasunut nappaatinullu aalajangersimasunut tunngatillugu, pitsaassutsimik naliliinermi uuttuutissanik suliniuteqartut siunnersuutit ataatsimut katersorlugit ineriartorteqqillugit uuttuusioqqullugit suliakkerneqarput. Akulikissuseq, navianassuseq, allanngorarneq aningaasartuutillu pitsaassutsimik naliliinermi uuttuutissatut toqqarneqartut tunngavigalugit tulleriiaarisoqarpoq.

Uuttuutigineqartussat, aaqqissuussaanerup peqqinnissamillu sullissinissamut ilinniagaqarsimassutsip pitsaassusaa takuneqarsinnaasunngorlugu toqqagaapput. Uuttuutigineqartussanik toqqaanermi aaqqissuussaaneq, napparsimasut sullinneqarneranni periaatsit ataqatigiinnerat angusallu pillugit paasissutissat napparsimasunit atorneqarsinnaasunngortinneqassapput. Suliniuteqaqatigiit samminiarpaat:

- Kræftimik nappaateqarneq (iviangikkut, puatsigut, illissap paavatigut, inalugarsuakkut erlukkullu, milakkut)

- Uummatikkut taqqatigullu nappaateqarneq (uummatip taqaanik milittoorneq, qaratsap taqaanik milittoorneq aanaartoornerlu)

- Nappaatit anigorneqarsinnaanngitsut (sukkorneq astmalu)

- Naartuneq erninerlu

- Meeqqat inuusuttullu 
- Peqqissuunissaq pitsaaliuinerlu

- Napparsimasut kikkulluunniit sullinneqarnerisa ataqatigiissup immikkoortuisa erseqqissaaviginissaannut uuttuutit

- Eqqarsartaatsikkut peqqissuseq

- Maannangaaq paasissutissanik naapertuuttunik katersisoqarsinnaaneranik naliliinikkut, nalunaarusiami ilanngunneqartunik, uutttuutigisassatut atugassanik arlalinnik suliniuteqaqatigiit toqqaasimapput

- Tamatuma saniatigut ukiuni aggersuni Nunat Avannarliit akornanni nallersuussinnaalernissamut unammilleqatigiinnermilu uuttuutigineqarsinnaasunik, suliniuteqaqatigiit suliaqarlutillu ineriartortitsipput

- Paasissutissat Nunat Avannarliit akornanni nallersuussisinnaalersitsisut, assigiinngitsorpassuartigut pissarsiarineqarsinnaanerat, allatigulli paasissutissat annikitsuinnaanerat, nalunaarusiami erserpoq. Taamaammat Nunani Avannarlerni, arlalitsigut pitsaassutsimut uuttuutinik ataatsimoorussanik, ineriartortitsinissaq suli pisariaqarpoq.

Eqqarsartaatsikkut peqqissutsimut tunngatillugu sullissinermi, napparsimasup peqqinnissaqarfiup iluani aqqusaagaanik ersersitsisumik, pitsaaliuinikkut inuunerissarnikkullu, (inuunermi atugassarititaasut atugarissaassuserlu pillugit paasissutissanik pisariaqartitsineq assersuutigineqarsinnaavoq) pitsaassutsip naliliiviginissaanut uuttuutissat ineriartortittariaqarput.

Paasissutissat tutsuiginartut ataavartumik NOMESCO-p akisussaaffigisaanut nalunaarutigisarnissaat innersuussutaavoq.

\section{Qarnup kigutillu paarinissaannut pitsaassutsimik naliliinermi uuttuutissat}

Kigutigissaanerup pitsaassusaa malittaralugulu, Nunat Avannarliit akornanni assersuussisinnaalissagaanni, qarnup kigutillu paarinissaannut pitsaassutsimik naliliinissamut uuttuuteqartariaqarnera ersarippoq. Nunani ataasiakkaani sullissinermi pitsaassutsimut uutuuteqaraluaq, nunat akornanni ataatsimoorussanik uuttuuteqannginnera suliniuteqarniarnermut tunngaviuvoq. 
Suliniuteqaqatigiit suliassaattut aalajangersagaq naapertorlugu kigutigissaanermut tunngatillu Nunani Avannarlerni ataatsimoorussamik pitsaassutsimut uuttuuteqalernissaanut siunnersuusiussapput. Suliaq OECD-mut siulianilu suliniummut EGOHID-imut atassuteqassaaq. Suliniuteqaqatigiit ukiunik 3-nik piffissalerlugit 2007-imiit sulisinneqarput. Qallunaat Nunaat, Savalimmiut, Finland, Island, Norge Sverigelu peqataapput. Finland suliniummut ataqatigiissaarisuuvoq.

Nunani Avannarlerni kigutigissaanermut tunngatillugu pitsaassutsimut uuttuutigineqartartunik pioreersunik, taakkulu tunngavilersuutaannik misissuinermik, suliniut aallarnerneqarpoq. ECHI (European Community Health Indicators), OECD-llu maleruagassiaani, EGOHID-suliniummi (European Global Oral Health Indicators Development Project), Nunallu Avannarliit immikkut soqutigisaat naapertorlugit uuttuutigineqartussat toqqarneqarput.

Uuttuutigineqartussatut toqqakkat immikkoortunut 4-nut agguarneqarput: aaqqissuussaanermut, ingerlaatsimut, naammassisanut pitsaassutsimullu uuttuuttaasinnaajumaartunut - uuttuutigineqartussatut pinngitsooratik qaqinneqartussaasut.

Suliniuteqaqatigiit aaqqissuussaanermut uuttuutissatut 4-nik siunnersuuteqarput: 1. Kigutigissaanermik sulisinnaatitaasup soraarninngornissaminik nalliisimanngitsup agguaqatigiissillugit innuttaasut sullitaasa amerlassusaat, 2. Kigutigissaasut sulisinnaasut soraarninngornissaminnik nalliisimanngitsut agguaqatigiissillugit innuttaasut sullitaasa amerlassusaat, 3. Kigutigissaasunut naleqqiullugit kigutilerisut soraarninngornissaminnik nalliissimanngitsut amerlassusaat, 4. Innuttaasumut ataatsimut naatsorsuullugit kigutigissaanermi aningaasartuutit, 3 ingerlaatsip pitsaassusaanut uuttuutit: 1. Ukiup 1-p ingerlanerani \%-inngorlugit innuttaassut kigutileriviliarsimasut amerlassusaat, 2. Kigutit salittarnerisa akuttussusaat (ullormut 1 sinnerlugu), 3. Imeruersaatinik sukkulinnik imigaqarnerup annertussusaa, 5 naammassisat pitsaassusaannut uuttuutit: 1. Meeqqat inuusuttullu misissorneqartut akornanni putoqanngitsunik kigutillit amerlassusaat, 2. Agguaqatigiissillugu meeqqani inuusuttunilu misissortittuni kigutilunneq (DMFT), 3. Qarnup kigutillu peqqissusaannut tunngatillugu nalunaarsukkat (SiC), 4. Innuttaasut akornanni 65-iniit 74-inut ukiulinni \%-inngorlugit kiguteqanngitsut amerlassusaat, 5. Innuttaasut akornanni 65-iniit 74-inut ukiulinni kigutaat ikinnerpaamik 20-it amiakkuulersut 3 pitsaassutsimut uuttuutaajumaartussat: 1 . Innuttaasut aalajangersimasumik kigutileriviliartartut amerlassusaat, 2. Kigutigissutsip (qanerissutsip) nammineq naliliiviginera, 3. 
Tamuasinnaassutsip nammineq naliliiviginera. Nunat Avannarliit akornanni ikinnerpaamik nunat 3 paasissutissanik pigisaqarnissaat uutuutissanik aalajangiussinermi piumasaqaataavoq.

Assigiinnik naapertuuttunillu Nunat Avannarliit akornanni kigutigissaanermi paasissutissanik pissarsinissap ajornakusoornerata, paasissutissat pitsaassutsimik uuttuiniarnermi atugassat ilaasa amigaataasarnerisa takutippaa. Suliap annersaa nassuiaatinut tunngassuteqarpoq, taamaammallu paasissutissat katersorneqarsimasut amerlanersaat periutsinik angusanillu assersuussinermi atorneqarsinnaallutik, ineriartortitsinissamulli suli nukinnik atuisoqartariaqarpoq.

Nunat Avannarliit tamarmiullutik pitsaassutsimut uuttuutissanut, assigiinnik periuseqarnikkut paasissutissanik pissarsinissamik sulissuteqarnissaasa pingaaruteqassusia suliniuteqaqatigiit naqissuserpaat, ass. nassuiaatit assigiit ukioqatigiiaallu. Siunissami kigutigissaanermi pitsaassutsimik uuttuutissat amerlanerunissaat, suliniuteqarnerullu nanginneqarnissaa suliniuteqaqatigiit isumaqatigiissutigaat.

\section{Napparsimasut isumannaatsumik sullinneqarnissaat pillugu pitsaassutsimik naliliinermi uuttuutissat}

Ukiut 10-t kingulliit ingerlaneranni napparsimasut isumannaatsumik sullinneqarnissaat annertuumik soqutigineqalerpoq. Nunani assigiinngitsuni ilisimatusaatigalugit misissuinerit annertuut, napparsimasut ikinngitsut piaarinaatsoornikkut ajoquserneqartarnerat takutippaat. Ajoquserneqarnerit ilaatigut makkuusinnaasut: nappaatinik suussusersinngitsoornerit kingusinaarluniluunniit suussusersinerit, kukkusumik pilatsinnerit, kukkusumik nakorsaasiinerit eqqiluisaannginnermillu patsiseqartumik aseruuttoornerit navianaatillit.

Navianaataasinnaasut kukkunerillu peqqinnissaqarfimmi eqqumaffiginerulerneqarnerannut ilisimatusarnerit sunniuteqaqataapput, isumannaatsumillu sullissinissap ineriartortinneqarneranut pilertornerulersitsillutik. Ajoqusiinermi naalliuutit inunnut ataasiakkaanut qanigisaasunullu tuttut annikillisinnerisa saniatigut isumannaallisaaneq aningaasanik sipaarfiuvoq. Napparsimmaveqarfimmi ajoqusernerit sivisunerusumik uninnganermik, aningaasartuutit annertusinerannik allallu periarfissaasa annikillinerannik kinguneqartarput. Tamatuma saniatigut inuiaqatigiinnut annertuumik aningaasartuutaasarpoq. 
Peqqinnissaqarfik suliffeqarfiuvoq imaannaanngitsoq navianartorsiorfiugajuttorlu, taamaammallu aaqqissuussaanikkut sumiluunniit inissisimagaanni, isumannaallisaanerup pitsanngorsaavigiuarnissaa suleqataaffigisariaqarpoq. Navianartut maluginiarlugit iliuuseqarfigisarnissaat peqqinnissaqarfimmi sullissinermut nalinginnaasumut ilaatittariaqarpoq. Taamaaliussagaanni sillimaniarnermut atatillugu kultureqartariaqarpoq, sulisut kukkussutiminnik ammasumik nalunaarutiginnittarsinnaanerat oqallisiginnittarsinnaanerallu periarfissillugu assinganik kukkusoqaqqinnissaa pinngitsoortinniartariaqarpoq. Eqqortumik iliornissaq ajornannginnerusariaqarpoq, kukkunissarlu ajornarnerusariaqarluni. Misissuinerit, nakorsaanerit peqqissaanerillu ilisimatuussutsikkut paasisanik tunngaveqarlutillu misilittakkanik aallaaveqarnissaat, napparsimasunik sullissinermi isumannaallisaanissami pisariaqartinneqarpoq.

Isumannaatsumik sullinneqarneq innuttaaqatit peqqinnissaqarfimmut tatiginninnerannik annertusititsisuusarpoq. Taamaammat peqqinnissaqarfimmi napparsimasunik sullissinerup isumannaatsuunerata naliliiviginissaanut uuttuutissanik ineriartortitsinissaq pingaaruteqarpoq. Napparsimasunik sullissinermi isumannaallisaanermut tunngatillugu ilisimatusarneq ilisimasanillu katersineq qanittumi aallartinneqarpoq. Taamaammat aaqqissuussaanikkut periarfissat paasissutissallu katersat nalunaarsuivissaat amigaatigineqarput, taamatuttaaq ilisimatuussutsikkut paasisat ilisimalikkallu tunngavissat pillugit nalunaarsukkat pisariaqartinneqartut, pitsaassutsimik naliliinissamut uuttuutigissallugit tunngavissiilluartut amigaatigineqarput. Napparsimasunik sullissinermi isumanaallisaanerup pitsaassusaanik naliliinermi uuttuutissanik ineriartortitsilluni suliaqarneq OECD-mi EU-milu aallartinneqarpoq, Nunanilu Avannarlerni suleqatigiinneq tamatumunnga pingaarutilimmik tunniussassaqarpoq.

\section{Sullinneqarnerup pitsaassusaanik napparsimasut misigisaat tunngavigalugit pitsaassutsimik naliliinermi uuttuutissat}

Napparsimasut misilittagaat naliliinerallu peqqinnissaqarfimmi sullissi-nermi pingaaruteqarnerit ilagaat. Taamaammat Nunani Avannarlerni napparsimasunik sullissinermi pitsaassutsip nalilernissaanut uuttuutissanik suliniuteqaqatigiit ilaasa napparsimasut misigisaat tunngavigalugit pitsaassutsimik naliliinissamut uuttuutissat sammivaat. 
Sullinneqarnerup pitsaassusaanik napparsimasut misigisaat tunngavigalugit naliliinermi uuttuutissanik pissarsinissaq suliniuteqaqatigiinnut suliassiissutigineqarpoq. Nunanilu Avannarlerni nalunaarsuinermi nakkutilliinermilu paasissutissanik assersuussisinnaanermut tunngaviullutik uuttuutaasinnaasunik, 6iniit 12-inut amerlassusilinnik, siunnersuusiornissamut pisussaaffilerneqarputtaaq.

Nunat Avannarliit naalagaaffiisa immikkut atuisuminnik misissuisitsineri assigiinngissuteqarput. Napparsimasut sullinneqarnertik pillugu misigisaannik misissuisitsinitik arlaannaataluunniit taarserusunngikkai piaartumik paasinarsivoq. Taamaasillutik Nunat Avannarliit pitsaassutsimut uuttuutigiligassaasa nunani ataasiakkaani pioreersunut tapertaanissaat suliniuteqaqatigiit aalajangiuppaat.

Inersimasut timikkut nappaateqarnertik pissutigalugu ulloq unnuarlu uninngaviusartuni sullinneqarnerminni misilittagaannut tunngatillugu, apeqqutit 8 suliniuteqaqatigiit isumaqatigiissutigaat. Apeqqutit ilaat 6-it sulisunut tunngassuteqarput, ataaseq kukkusumik nakorsarneqarnermut, ataaserlu pissutsit ataatsimut isigalugit naliliinermut tunngalluni. Nutserinermi periutsit aalajangersimasut, apersueriaaseq aalajangersimasoq kiisalu apeqqutit misiligutigeqqaarnerat suliniuteqaqatigiit sulinerminni tunngavigaat. Nutserinerit, apersuinerit misiliinerillu periutsip tamatuma pitsaasuuneranik takutitsipput. Apeqqutit 8 pineqartut NORPEQ-imik atserneqarput (NORdic Patient Experiences Questionnaire).

Norgep 2006-imi misissuisitsinermini NORPEQ ilannguppaa. Nunat allat nutsereqqaarlutik, apersueqqaarlutik misileeqqaarlutillu misissuisitsinissaminni NORPEQ ilanngutissagaat anguniagassatut siunniunneqarpoq. Nunat Avannarliit allat misissuinerannut NORPEQ-ip ilanngunnissaanut aningaasaliissutitigut, aaqqissuussaanikkut inatsisitigullu akornutissaqartoq paasinarsivoq.

Nunat immikkut napparsimasut misilittagaannik paasiniaaneranni NORPEQ-ip ilanngunneqarnerata peqqinnissaq pillugu politikkikkut aalajangiinernut ilaatinneqartarnissaa, ukiunilu aggersuni malittarineqarnissaa, suliniuteqaqatigiit pingaarutilittut tikkuarpaat.

Immikkut ilisimasalinnit peqqissaaveqarfinnilu sullinneqarneq ataatsimut isigalugit, NORPEQ inersimasunut timikkut nappaatilinnut, ulloq unnuarlu paaqqutarisarialinnut pingaartunut amerlanngitsunulli, naleqqussagaavoq. Norgemi peqqinnissaq pillugu ilisimatusarfik allatseqarfillu, Nunani Avannarlerni tamani napparsimasunut tamanut, eqqarsartaatsikkut timikkullu nappaatilinnut atorneqarsinnaasunik, apeqqutinik pingaarutilinnik 10-nik 
ineriartortitaminik misileraasimavoq. Taakku Nunanit Avannarlernit allanit atorneqarsinnaalerput, siunissamilu pitsaassutsimik uuttuutitut atorneqarsinnaassalluni. Uuttuutit suliniummit OECD responsiveness-imit aallaaveqartut, Nunani Avannarlerni suliniuteqarnermi uuttuutitut aamma atorneqarsinnaapput.

\section{Siunissamut isumaliutersuutit}

Nunani Avannarlerni peqqinnissaqarfiit sullissinerisa naliliivigalugillu nakkutigineqarnerat kingunissaqarluartoq, Nunanullu Avannarlernut tamanut naapertuuttunik pitsaassutsimut uuttuusiortoqarsinnaanera, nalunaarusiami uppernarsineqarput. Taamaakkaluaq paasissutissat pitsaassusaasa, soorlu uppernassusaasa paasissutissanillu pissarsiniarnerup qulakkeernissaannut annertuumik sulisoqartariaqarpoq.

Paasisat ilaat assersuussinernut atorsinnaanngillat, sullissinermili pitsaassutsit assigiinngissuteqarnerannik apeqqusiisinnaapput. Taamaammat Nunat Avannarliit akornanni assersuussisinnaalernissamut atugassanik, paasissutissanik tutsuiginartunik pissarsinissap qulakkeernissaanut nukiit annertuut atorneqartariaqarput. Taamatuttaaq pitsaassutsimut uuttuutigineqarsinnaasunik uummaarissumik ineriartortitsinissaq pisariaqarpoq.

Pingaarutilinni paasissutissat, Nunat Avannarliit akunnerminni assersuussisinnaanissaannut atugassat, pissarsiarineqarsinnaannginnerat ilanngullugu taaneqarpoq. Taamaasilluni Nunani Avannarlerni napparsimasunik sullissinermi isumannaallisaaneq pillugu paasissutissat pissarsiarineqarsinnaasimanngillat.

Nunarsuaq tamakkerlugu pitsaassutsimut uuttuutigineqartussanik ineriartortitsineq aallartinneqaqqammerpoq, Nunallu Avannarliit ineriartornemi tamatumani peqataanissaat naatsorsuutigineqarpoq.

Eqqarsartaatsikkut peqqissutsimut tunngatillugu, napparsimasut peqqinnissaqarfimmi aqqusaartortagaat pillugit, pitsaassutsimik naliliinissami uuttuutissanik ineriartortitsinissaq annertuumik pisariaqartinneqarpoq. Tamatumunnga tunngasunik nunarsuaq tamakkerlugu annikitsuinnarnik paasissutissaqarpoq. Nunat Avannarliit peqataanerisigut, pitsaaliuineq peqqissuunissamillu suliniuteqarneq ilanngullugit, pitsaassutimut uuttuutissanik pitsaasunik ineriartortitsisoqarsinnaasoq, nalilerneqarpoq. 
Qarnup kigutillu peqqissuunissaat pillugu pitsaassutsimut uuttuutissanik suliaqarnermi Nunani Avannarlerni annertuumik angusaqartoqarsimanera takuneqarsinnaavoq. Taamaattoq suli ineriartortitsinissap pisariaqarnera erseqqissarneqarpoq.

Sullisssinermi pitsaassutsip uuttorneqarnissaa pillugu Nunat Avannarliit Ministeriisa Siunnersuisoqatigiivisa suliniuteqaqatigiivini sulinerup, ullutsinni peqqinnissaqarfimmi sullissinerit pingaarutillit pitsaassusaannik takussutissiornissaannut periarfissakippallaarnera ersersippaa.

Nunalli Avannarliit ineriartortitsinissamut periarfissarissaarput. Suliniut una tunngavissaqqissutut nalilerneqarpoq. Tapiliullugillu innersuussutigineqarput:

- Pitsaassutsimut uuttuutissatut toqqakkanut paasissutissat tutsuiginartut pigineqarpata, innuttaasut, politikerit, peqqinnissamik sullissisut pisortallu Nunani Avannarlerni peqqinnissaqarfiit sullissinerisa pitsaassusaanik malinnaatissinnaanngorlugit NOMESCO-p ataani saqqummiunneqartarnissaat

- Eqqarsartaatsikkut peqqissuseq, pitsaaliuineq peqqissuunissarlu pillugit sullissinermi pitsaassutsip naliliiviginissaanut uuttuutissanik ineriartortitsinissaq pillugu Nunat Avannarliit Ministeriisa Siunnersuisoqatigiivisa ataanni suleqatigiissitaliornissaq

- Napparsimasunik sullissinermi isumannaallisaanermi suleqatigiinnerup ineriartortinnissaa pillugu Nunat Avannarliit Ministeriisa Siunnersuisoqatigiivisa ataanni suleqatigiissitaliornissaq

- Qarnup kigutillu peqqissusaat pillugu naliliinissamut uuttuutissat ineriartortinnissaat pillugit Nunat Avannarliit Ministeriisa Siunnersuisoqatigiivisa ataanni suleqatigiissitaliornissaq. 



\section{Samantekt}

Á Norðurlöndum er mikil áhersla lögð á gæðabróun og öryggi sjúklinga og í viðkomandi löndum hafa verið sett af stað skilvirk próunarverkefni til að varpa ljósi á gæði heilbrigðispjónustunnar.

Á Norðurlöndum eru einstök tækifæri til að mæla pjónustuna og hafa eftirlit með henni vegna pess að öll löndin skrá jafnóðum gögn í heilbrigðisskrár.

Í framhaldi af pessu kom norræna ráðherranefndin á fót fjórum hlutaverkefnum sem hafa pað að markmiði að stuðla að próun gæðavísa til að Norðurlöndin geti miðlað sín á milli, borið saman og sett viðmiðanir í heilbrigðispjónustu.

Aðalmarkmiðið er að gefa norrænum borgurum, stjórnmálamönnum, heilbrigðisstarfsmönnum og heilbrigðisyfirvöldum tækifæri til að meta og bera saman heilbrigðispjónustu í öllum Norðurlöndunum. Annað markmið er að skilgreina svið par sem Norðurlandapjóðirnar geta lært hver af annarri með pað fyrir augum að auka gæði peirra heilbrigðispjónustu sem sjúklingar fá, pví allt snýst petta um pá.

Í pví skyni stofnaði Norræna ráðherranefndin fjóra verkefnishópa sem áttu að skoða eftirfarandi pætti á tímabilinu 2007-2010:

- Almenna og sjúkdómstengda gæðavísa

- Gæðavísa fyrir munn- og tannheilsu

- Gæðavísa fyrir öryggi sjúklinga

- Gæðavísa um reynslu sjúklinga af gæðum heilbrigðisbjónustunnar.

Á verkefnistímanum hefur verið náin samvinna við OECD til að tryggja samvinnu í alpjóðlegri vinnu með gæðavísana. Gæðavísar OECD eru teknir með í peirri vinnu sem liggur fyrir. Vinnu verkefnishópanna fjögurra er lýst hér að neðan. 


\section{Almennir og sjúkdómstengdir gæðavísar}

Verkefnishópurinn sem fjallar um almenna og sjúkdómstengda gæðavísa hefur fengist við pað verkefni að útbúa, kortleggja og próa frekar tillögur að vísum sem geta lagt grundvöllinn að skráningu og eftirliti með gæðum heilbrigðispjónustu norrænu pjóðanna. Deim gæðavísum sem valdir eru er forgangsraðað með tilliti til tíðni, alvarleika, dreifingar og fjárhagslegra pátta.

Vísarnir eru valdir með pað fyrir augum að peir endurspegli bæði gæðin í skipulagningu og faglegu hliðina á heilbrigðispjónustunni. Eins eru vísarnir valdir til að lýsa innri skipulagi, bjónustu við sjúklinginn (ferlinu) ásamt bví hvernig sjúklingnum farnast.

Verkefnishópurinn hefur valið að skoða eftirfarandi svið:

- Krabbameinssjúkdómar (brjóstakrabbamein, lungnakrabbamein, leghálskrabbamein, ristil- og endaparmskrabbamein, sortuæxli)

- Hjarta- og kransæðasjúkdómar (kransæðastífla, blóðtappe í heila og heilablæðing)

- Krónískir sjúkdómar (sykursýki og astmi)

- Meðganga og fæðing

- Börn og unglingar

- Heilsuefling og forvarnir

- Almennir vísar sem lýsa páttum í ferli hvers sjúklings

- Geðheilbrigði.

Verkefnishópurinn hefur valið nokkra vísa par sem sýnt pykir að hægt er að safna viðeigandi gögnum og sem eru birtir í skýrslunni.

Auk pess hefur verkefnishópurinn samið og próað mögulega vísa sem meta má sem hluta af samanburði og settum viðmiðunum í norrænum löndum á komandi árum.

Í skýrslunni kemur fram að á mjög mörgum sviðum er unnt að útvega gögn sem gera samanburð á norrænu löndunum mögulegan en á öðrum sviðum finnst lítið af gögnum. Petta býðir að á mörgum sviðum er áframhaldandi pörf á að próa samnorræna gæðavísa. 
pað á t.d. við í tengslum við geðheilbrigði, bar sem nauðsyn er á að próa gæðavísa, sem lýsa ferli sjúklingsins í heilbrigðiskerfinu, ásamt forvörnum og heilsueflingu, bar sem pörf er á meiri gögnum varðandi lífsaðstæður og lífskjör.

Á peim sviðum par sem finnast aðgengileg gögn er ráðlagt að gögnin séu birt jafnóðum á vegum NOMESCO.

\section{Gæðavísar fyrir munn- og tannheilbrigðispjónustuna}

Norðurlöndin gera sér ljósa grein fyrir nauðsyn gæðavísa fyrir tannheilbrigðispjónustuna, til að fylgjast með gæðum tannverndar og bera saman árangur innan Norðurlandanna. Verkefnið er tilkomið vegna skorts á samræmdum gæðavísum innan Norðurlandanna, enda pótt unnið hafi verið að eflingu gæðastarfs á sviði tannheilbrigðispjónustu í hverju landi fyrir sig.

Við skipun starfshópsins kom fram að verkefni hans væri að undirbúa tillögu að samræmdum norrænum gæðavísum fyrir tannheilbrigðispjó-nustuna. Starfið skyldi tengjast OECD (Efnahags- og framfarastofnuninni) og EGOHID verkefninu (European Global Oral Health Indicators Development Evrópsk allsherjaráætlun um próun heilbrigðisvísa á sviði munnheilsu). Skipunartímabil starfshópsins var prjú ár en verkefninu var hleypt af stokkunum árið 2007. Danmörk, Færeyjar, Finnland, Ísland, Noregur og Svípjóð voru pátttakendur í verkefninu. Finnland pjónaði hlut-verki samræmingaraðila fyrir pað.

Verkefnið hófst með yfirferð yfir bá tannheilbrigðisvísa sem til staðar eru á Norðurlöndum og hugmyndafræðina sem liggur peim til grundvallar. Vísarnir voru valdir með hliðsjón af tilmælum ECHI (Heilbrigðis-vísum Evrópusambandsins), tilmælum OECD, EGOHID starfinu og með hliðsjón af sértækum hagsmunum norrænu landanna.

Vísunum var skipt niður í fjóra flokka: grunnvísa, ferlisvísa, árangursvísa og mögulega gæðavísa - sem verði skoðaðir í framtíðinni. Starf-shópurinn var sammála um fjóra grunnvísa: 1. fjöldi íbúa miðað við löggilda starfsmenn tannverndar undir eftirlaunaaldri, 2. fjöldi íbúa miðað við virka starfsmenn tannverndar undir eftirlaunaaldri, 3. fjöldi tannlækna undir eftirlaunaaldri miðað við starfsmenn tannverndar, 4. kostnaður við tannvernd á íbúa, prjá ferlisvísa: 1. hlutfall (\%) íbúa sem hefur leitað til tannheilbrigðisbjónust-unnar á einu ári, 2. tannburstunartíðni (oftar en einu sinni á dag), 3. neysla gosdryk- 
kja er innihalda sykur, fimm árangursvísa: 1. hlutfall skoðaðra barna og unglinga sem eru laus við tannskemmdir, 2. meðalgildi DMFT tannátustuðuls (decayed, missing, filled, teeth) hjá börnum og unglingum, 3. SiC (Significant Caries Index) mælikvarði á tíðni tannskemmda, 4. hlutfall (\%) tannlausra íbúa á aldrinum 65-74 ára, 5. hlutfall (\%) einstaklinga á aldrinum 65- 74 ára, sem hafa að minnsta kosti 20 tennur eftir í munninum og prjá mögulega gæðavísa: 1. hlutfall íbúa sem leitar reglulega til tannheilbrigðispjónustunnar, 2. tannheilsa (munnheilsa) að eigin mati , 3. tyggingarhæfni að eigin mati. Dau skilyrði, sem sett voru til að vísarnir yrðu teknir til greina, voru að upplýsingar væri að finna um pá í að minnsta kosti premur af norrænu löndunum.

Skortur á upplýsingum um nokkra af árangursvísunum endurspeglar hversu erfitt er að fá fram heildræna og raunverulega mynd af ástandi gæðamála í tannheilbrigðispjónustunni í norrænu löndunum. Mikil vinna hefur verið lögð í að skilgreina vísana og par af leiðandi er hægt að nýta meirihlutann af peim upplýsingum sem safnað hefur verið saman til samanburðar og sem viðmið, en samt sem áður er pörf á enn frekari vinnu við að próa viðeigandi gæðavísa.

Starfshópurinn hefur lagt áherslu á mikilvægi pess að öll norrænu löndin vinni að pví að afla upplýsinga um viðurkennda vísa með beitingu sömu aðferða, t.d. nákvæmlega sömu skilgreiningar og sambærilega aldurshópa. Í framtíðinni verða gerðar kröfur um fleiri gæðavísa fyrir tannheilbrigðispjónustuna og var starfshópurinn einhuga um að starfinu skyldi haldið áfram.

\section{Gæðavísar fyrir öryggi sjúklinga}

Á undaförnum tíu árum hefur hugtakið öryggi sjúklinga fengið mikla athygli. Niðurstaða fjölda rannsókna í mörgum ólíkum löndum hefur gefið ótvírætt til kynna að margir sjúklingar verði fyrir ónauðsynlegum skaða í heilbrigðispjónustunni. Um getur verið að ræða sjúkdómsgreiningar sem hafa annað hvort voru ekki réttar eða gerðar of seint, röng inngrip, ranga lyfjameðferð eða ófullnægjandi hreinlæti sem getur leitt til alvarlegra sýkinga.

Rannsóknirnar hafa leitt til pess að nánari gaumur hefur verið gefinn að áhættupáttum og misbresti í heilbrigðispjónustunni og flýtt fyrir próuninni í átt að auknu öryggi sjúklinga. Auk pess að draga úr peim pjáningum sem pessir skaðar valda bæði sjúklingum og aðstandendum, borgar bað sig jafn- 
framt út frá fjárhagslegu sjónarmiði að bæta öryggi sjúklinga. Skaðar sem orsakaðir eru af heilbrigðispjónustunni leiða til aukins legutíma á sjúkrahúsum, sem felur síðan í sér bæði aukinn kostnað og verra aðgengi. Auk pess skapast af pví verulegur kostnaður fyrir pjóðfélagið.

Heilbrigðispjónustan er flókin áhættustarfsemi sem krefst aðgerða á öllum stigum hennar til að auka sjúklingaöryggi. Að vera vakandi fyrir og bregðast við áhættum á að vera eðlilegur páttur í vinnulagi heilbrigðispjónustunnar. Til pess er nauðsynlegt að innleiða öryggisbrag sem gerir starfsfólki kleift að tilkynna og ræða atvik með pað fyrir augum að ýta úr vör aðgerðum til að koma í veg fyrir að slík atvik endurtaki sig. að á að vera auðvelt að gera rétt og erfitt að gera mistök. Forsenda fyrir miklu öryggi sjúklinga er að rannsóknir, meðferðir og umönnun byggi á vísindalegri pekkingu og bestu reynslu.

раð að tryggja öryggi sjúklinga er forsenda pess að hægt sé að viðhalda tiltrú samborgaranna á heilbrigðispjónustunni. pað er par af leiðandi brýnt verkefni að próa vísa sem lýsa öryggi sjúklinga innan heilbrigðisbjónustunnar. Rannsóknastarf og pekkingaröflun varðandi öryggi sjúklinga er tiltölulega nýlega hafið og pví hefur sviðið ekki á að skipa virku skipulagi og skrám til upplýsingasöfnunar, auk peirrar bekkingar og skráðra vísindalegra heimilda sem parf til að taka upp vel rökstudda vísa. Starfinu við próun vísa á sviði sjúklingaöryggis hefur verið ýtt úr vör innan Efnahags- og framfarastofnunarinnar (OECD) og Evrópusambandsins (ESB) og norrænt samstarf getur lagt sitt verðmæta framlag af mörkum pví til stuðnings.

\section{Norrænt gæðamat á reynslu sjúklinga af heilbrigðiskerfinu}

Reynsla sjúklinga af pjónustunni og ánægja með hana er mikilvægur páttur í gæðum heilbrigðisbjónustunnar. Einn starfshópanna í norræna samstarfinu hefur bví unnið að pví að próa vísa til að mæla hvernig sjúklingar meta gæði pjónustunnar.

Verkefni starfshópsins var að útbúa vísa og mælitæki sem endurspegla hvernig sjúklingar upplifa gæði pjónustunnar. Verkefni hópsins var að leggja til 6-12 mögulega vísa sem gætu verið grundvöllur að skráningu og vöktun á sviðinu til að unnt væri að bera saman gögn frá öllum Nor-ðurlöndunum. 
Notendakannanir á landsvísu í norrænu löndunum eru að sumu leyti mismunandi. Раð varð fljótlega ljóst að ekkert landanna var reiðubúið til að skipta út landsrannsóknum á reynslu sjúklinga sem pegar voru fyrir hendi. par af leiðandi ákvað hópurinn að norrænu vísarnir skyldu samhæfðir og vera viðbót við fyrirliggjandi rannsóknir í hverju landi fyrir sig.

Hópurinn varð sammála um átta spurningar fyrir fullorðna, líkamlega veika sjúklinga sem liggja inni lengur en í einn sólarhring, en sex spurninganna varða samskipti við heilbrigðisstarfsfólk, ein varðar ranga meðhöndlun og ein varðar almenna ánægju.

Hópurinn útbjó staðlaðar aðferðir við pýðingu, viðtöl og forrannsóknir á spurningunum. býðingarnar, viðtölin og forprófanirnar sýna að mælitækið virkar með fullnægjandi hætti. Spurningarnar átta kallast NORPEQ (NORdic Patient Experiences Questionnaire).

Í Noregi var NORPEQ hluti af landsrannsókn sem fór fram árið 2006. Markmiðið var að hin ríkin myndu einnig nota NORPEQ í fyrirhugðum innlendum rannsóknum eftir að býðingu, viðtölum og forrannsóknum væri lokið í hverju landi fyrir sig. Í ljós kom að fleiri hindranir voru í vegi pess að hafa NORPEQ með í öðrum innlendum landsrannsóknum, bæði með tilliti til fjármögnunar, skipulags innan hvers lands og lagaramma.

Starfshópurinn bendir á mikilvægi pess að NORPEQ verði fest í sessi sem hluti innlendra landsrannsókna á reynslu sjúklinga með skýrum heilbrigðispólitískum ákvörðunum hvers lands og að peim verði fylgt eftir á komandi árum.

NORPEQ-spurningarnar miðast við fullorðna, líkamlega veika inniliggjandi sjúklinga, sem er mikilvægur en afmarkaður hópur sjúklinga pegar tekið er mið af sérfræði- og frumheilbrigðisbjónustunni í heild. Innlent pekkingarsetur í págu heilbrigðispjónustunnar (Nationalt kunnskapssenter) í Noregi hefur próað og prófað 10 almennar kjarnaspurningar sem nota má fyrir níu sjúklingahópa, m.a. á geðsviði og á göngudeildum sjúkrahúsa. Hinar Norðurlandabjóðirnar hafa nú aðgang að pessu mælitæki og getur pað haft áhrif á mögulega norrænna gæðavísa pegar til lengri tíma er litið.

Gæðavísar sem byggja á niðurstöðum úr verkefni OECD á pessu sviði gætu einnig leitt til mögulegra gæðavísa fyrir norræna verkefnið pegar fram í sækir. 


\section{Sjónarmið}

pessi skýrsla sýnir fram á að fyrir hendi eru miklir möguleikar með tilliti til mælinga á og eftirlits með starfsemi heilbrigðiskerfis norrænu landanna, en einnig að draga megi pá ályktun að hægt sé að greina viðeigandi gæðavísa fyrir öll löndin. Eftir sem áður er pörf fyrir umtalsverða vinnu við að tryggja gæði gagnanna, par með gildi (validitet) ásamt pví að útvega gögn frá ýmsum sviðum til viðbótar.

Hluta peirra niðurstaðna, sem pegar eru aðgengilegar, verður tæpast hægt að nota til að veita réttan samanburð og setja viðmiðanir, heldur mætti fremur nota pær til að spyrja hvort í reynd fyrirfinnist raunverulegur munur á gæðum veittrar bjónustu. Pess vegna er nauðsynlegt að leggja í umtalsverða vinnu við að tryggja gild, nýleg gögn til að unnt verði að fá fram raunhæfan samanburð og viðmið fyrir norrænu ríkin. Einnig er pörf fyrir sveigjanlega próun mögulegra gæðavísa.

Einnig kemur fram að ómögulegt er að afla gagna á mikilvægum sviðum til að hægt sé að bera saman norrænu löndin. Dar má nefna að ekki hefur verið hægt að útvega gögn sem varpa ljósi á öryggi sjúklinga í norrænu löndin. Á alpjóðavísu er pessi vinna við að próa gæðavísa nýlega hafin og pess er vænst að norrænu löndin geti lagt sitt af mörkum við próun peirra.

Að pví er varðar geðheilbrigði er pess að geta að nauðsynlegt er að leggja aukna áherslu á að próa gæðavísa sem skýra feril sjúklinganna innan heilbrigðiskerfisins. Á alpjóðavísu hefur umfjöllun um petta svið verið takmörkuð. Litið er svo á að norrænu löndin geti lagt sitt af mörkum til að próaðir verði faglegir gæðavísar bæði á pessu sviði og á sviði forvarna og heilsueflingar.

Norrænu ríkin hafa náð langt með próun gæðavísa á sviði munn- og tannheilsu. Rétt er pó að benda á að á pessu sviði parf frekari próun gæðavísa að eiga sér stað.

Vinna starfshópa Norrænu ráðherranefndarinnar m.t.t. gæðamælinga sýnir takmarkaða möguleika nútímaheilbrigðiskerfis til að skrá gæði bjónustunnar á mikilvægum sviðum.

Norrænu löndin hafa samt sem áður, eins og um getur, einstök tækifæri til að sinna próun á pessu sviði. Dróunarverkefnið sem hér hefur verið lýst er metið sem traustur grunnur fyrir slíka framhaldsvinnu. Í beinu framhaldi er pví mælt með 
- að á sviðum par sem fyrir liggja traust gögn í tengslum við hina völdu gæðavísa skuli NOMESCO birta pessi gögn jafnóðum með pað að markmiði að veita almenningi, stjórnmálamönnum, heilbrigðisstarfsfólki og stjórnvöldum yfirsýn yfir gæði pjónustunnar í heilbrigðiskerfinu á öllum Norðurlöndunum

- að á vegum Norræna ráðherranefndarinnar verði komið á fót starfshópi sem prói áfram samnorræna gæðavísa fyrir geðheilbrigði, ásamt forvörnum og heilsueflingu

- að komið verði á fót starfshópi á vegum Norræna ráðherranefndarinnar sem hafi pað meginverkefni að próa áfram samnorrænt samstarf um öryggi sjúklinga

- að á vegum Norræna ráðherranefndarinnar verði komið á fót starfshópi í pví skyni að próa áfram gæðavísa á sviði munn- og tannheilsu. 


\section{Bilag}

Bilag 1. Mandat for styregruppen

Bilag 2. Styregruppens repræsentanter

Bilag 3. Oversigt over nationale kliniske retningslinjer, databaser og programmer

Bilag 4. Lovgrundlag for indsamling og offentliggørelse af data for Danmark, Finland, Grønland, Island, Norge og Sverige

Bilag 5. Kliniske kvalitetsdatabaser i Danmark

Bilag 6. Nasjonale medisinske kvalitetsregistre i Norge

Bilag 7. Oversigt over øvrige deltagere i Mund- og tandeplejeprojektet

Bilag 8. NORPEQ på norsk med bakgrunnsspørsmål

Bilag 9. NORPEQ på dansk

Bilag 10. NORPEQ på finsk

Bilag 11. NORPEQ på færøysk

Bilag 12. NORPEQ på islandsk

Bilag 13. NORPEQ på svensk 


\section{Bilag 1.}

28. februar 2007

Opdateret 1. august 2007

Mandat for nordisk styregruppe for projekter vedr. kvalitetsmåling $i$ sundhedsvcesenet

Styregruppens overordnede formål er at fungere som forbindelsesled mellem på den ene side de nordiske nationale sundhedsmyndigheder og Nordisk Ministerråd og på den anden side den virksomhed, der udføres i de konkrete fælles-nordiske projekter vedr. kvalitetsmåling i sundhedsvæsenet. De konkrete fællesnordiske projekter omfatter følgende projekter:

- Mätning av patienterfarenheter i hälso - och slukvården. (projektleder: forskningsleder Øyvind Andresen Bjertnæs, kunnskabssenteret, Norge)

- Kvalitetsindikatorer - udvikling, samordning og benchmarking i det nordiske sundhedsvæsen (projektleder: professor, overlæge Jan Mainz, Sundhedsstyrelsen, Danmark)

- Utveckling och koordinering av gemensamma nordiska patientsäkerhetsindikatorer. (projektleder medicinalrådet Michael Soop, Socialstyrelsen, Sverige)

- Samnordiska kvalitetsindikatorer för mun- och tandhälsovården (projektleder: övertandläkare Kaj Rönnberg, Stakes/THL Institutet för hälsa och välfärd , Finland og fra Social- och hälsoministeriet Anne Nordblad, medicinalrådet).

Det kan senere besluttes af Embedsmandskomitéen for social- og sundhedspolitik (EK-S) at udvide styregruppens portefølje til at omfatte yderligere fælles-nordiske projekter vedr. kvalitetsmåling.

Styregruppens repræsentanter forudsættes at følge - og kontinuerligt have overblik over - virksomheden i de arbejdsgrupper, der omfattes af styregruppens portefølje og at formidle relevante resultater herfra til de nationale sundhedsmyndigheder i de nordiske lande og til Nordisk Ministerråd. 
Styregruppen kan på denne baggrund identificere - og foreslå - nye fællesnordiske projekter til fremme af arbejdet vedr. kvalitetsmåling inden for sundhedsvæsenet i Norden.

Styregruppen består af 1-2 repræsentanter fra hvert af de nordiske lande. Disse repræsentanter forudsættes at have kompetence og erfaring med kvalitetsmålingsarbejdet såvel nationalt og internationalt samt at være forankret i de respektive nationale sundhedsmyndigheder. Repræsentanterne forudsættes endvidere at have indgående kendskab til det hidtidige fællesnordiske arbejde vedr. kvalitetsmåling i sundhedsvæsenet.

Styregruppens repræsentanter udpeges af embedsmandskomitéen for social- og sundhedspolitik (EK-S).

Styregruppen træffer selv beslutning om formandskab, sekretariatsfunktion og mødeaktivitet (såfremt der findes behov for disse funktioner). Styregruppens mandatperiode starter 1. marts 2007 og slutter ved de konkrete projektvirksomheders afslutning. 


\section{Bilag 2.}

Reprcesentanter i styregruppen for nordiske kvalitetsmålingsprojekt

Danmark

Jan Mainz, professor, ledende overlæge, Sundhedsstyrelsen, OECDrepræsentant

(formand)

Jytte Burgaard, projektkoordinator, Sundhedsstyrelsen (sekretariat)

Finland

Anne Nordblad, medicinalråd, Social- och hälsovårdsministeriet

Mika Gissler, forskningsprofessor Stakes/THL Institutet för hälsa och välfärd

Færøerne

Høgni Debes Joensen, landslæge, Social- og Sundhedsministeriet

Grønland

Karna Jokumsen, sundhedsfaglig konsulent, Departementet for Familie og Sundhed

Island

Margrét Björnsdóttir, afdelingschef, Sundhedsministeriet, OECDrepræsentant

Norge

Jan Sigurd Røtnes, avdelingsdirektør, Sosial- og Helsedirektoratet, OECD-repræsentant

Geir Bukholm, afdelingsdirektør, Seniorrådgiver Nationalt Kunnskapssenter for Helsetjenesten, OECD-repræsentant

Målfrid Monge, suppleant, seniorrådgiver, Sosial- og helsedirektoratet Thorstein Ouren, afdelingsdirektør, Sosial- og helsedirektoratet

Sverige

Marie Lawrence, projektledare, Socialstyrelsen, OECD-repræsentant 


\section{Bilag 3.}

\section{Generiske og sygdomsspecifikke kvalitetsindikatorer}

Tabel 1. Oversigt over nationale kliniske retningslinjer

\begin{tabular}{|c|c|c|c|c|c|c|c|}
\hline Sygdom & Danmark & Finland & Færøerne & Grønland & Island & Norge & Sverige \\
\hline AMI & $\mathrm{Ja}$ & $\mathrm{Ja}$ & Nej & $\mathrm{Ja}$ & $\mathrm{Ja}$ & $\mathrm{Ja}^{5}$ & $\mathrm{Ja}$ \\
\hline Apopleksi & $\mathrm{Ja}$ & $\mathrm{Ja}$ & Nej & Nej & $\mathrm{Ja}$ & $\mathrm{Ja}^{6}$ & $\mathrm{Ja}$ \\
\hline Astma & $\mathrm{Ja}$ & $\mathrm{Ja}$ & $\mathrm{Nej}$ & Nej & $\mathrm{Ja}$ & Nej & $\mathrm{Ja}$ \\
\hline Diabetes & $\mathrm{Ja}$ & $\mathrm{Ja}$ & Nej & $\mathrm{Ja}$ & $\mathrm{Ja}$ & $\mathrm{Ja}^{7}$ & $\mathrm{Ja}$ \\
\hline Mental Health & $\mathrm{Ja}^{1}$ & $\mathrm{Ja}^{3}$ & Nej & Nej & Nej & $\mathrm{Ja}^{8}$ & $\mathrm{Ja}^{13}$ \\
\hline Generisk sygdom & & Nej & Nej & Nej & & $\mathrm{Nej}^{9}$ & \\
\hline Tyktarmskræft & $\mathrm{Ja}$ & Nej & Nej & $\mathrm{Ja}^{4}$ & Nej & $\mathrm{Ja}$ & $\mathrm{Ja}$ \\
\hline Endetarmskræft & $\mathrm{Ja}$ & Nej & Nej & $\mathrm{Ja}^{4}$ & Nej & $\mathrm{Ja}$ & $\mathrm{Ja}$ \\
\hline Lungekræft & $\mathrm{Ja}$ & $\mathrm{Ja}$ & Nej & $\mathrm{Ja}^{4}$ & Nej & $\mathrm{Ja}^{10}$ & $\mathrm{Ja}$ \\
\hline Brystkræft & $\mathrm{Ja}$ & $\mathrm{Ja}$ & $\mathrm{Nej}$ & $\mathrm{Ja}^{4}$ & Nej & $\mathrm{Ja}$ & $\mathrm{Ja}$ \\
\hline Prostatakræft & $\mathrm{Ja}^{2}$ & $\mathrm{Ja}$ & Nej & $\mathrm{Ja}^{4}$ & $\mathrm{Nej}$ & $\mathrm{Ja}$ & $\mathrm{Ja}$ \\
\hline Livmoderhalskræft & $\mathrm{Ja}$ & Nej & Nej & $\mathrm{Ja}$ & Nej & $\mathrm{Ja}^{11}$ & Nej \\
\hline Melanom & Nej & $\mathrm{Ja}$ & Nej & Nej & Nej & $\mathrm{Ja}^{12}$ & Nej \\
\hline
\end{tabular}

Noter

1 Referenceprogram for skizofreni

2 Klaringsrapport

$3 \mathrm{Ja}$, depression, emotionellt instabil personlighetsstörning, bipolär sjukdom, ätstörningar hos barn och ungdom, skitsofreni, posttraumatiskt stressyndrom, icke organisk sömnlöshet, beroendeförhållande orsakad av alkohol

$4 \mathrm{Ja}$, retningslinjer fra Dronning Ingrids Hospital, viderebehandles kun her

$5 \mathrm{Ja}$, Nasjonale retningslinjer for individuell primærforebygging av hjerte- og karsykdommer, 2009

$6 \mathrm{Ja}$, Nasjonale retningslinjer for behandling og rehabilitering ved hjerneslag. April 2010

$7 \mathrm{Ja}$, Nasjonal retningslinje. Diabetes Forebygging, diagnostikk og behandling, 2009

$8 \mathrm{Ja}$, vi har allerede en og flere er under produksjon - beh.av bipolare lidelser, beh. av dobbeldiagnoser og beh av skizofreni. Nasjonale retningslinjer for diagnostisering og behandling av voksne med depresjon i primær- og spesialisthelsetjenesten, 2009

9 Nei, Prioriteringsveileder utarbeidet ift de enkelte sykdomsgrupper for riktigere prioriteringer i spesialisthelsetjenesten

$10 \mathrm{Ja}$, medio 2010

$11 \mathrm{Ja}$, december 2010

$12 \mathrm{Ja}$, medio 2010

$13 \mathrm{Ja}$, vissa diagnoser. ångest och depression, och psykosociala insatser vid schizofeni 
Tabel 2. Oversigt over nationale kvalitetsdatabaser

\begin{tabular}{llllllll}
\hline Sygdom & Danmark & Finland & Færøerne & Grønland & Island & Norge & Sverige \\
\hline AMI & $\mathrm{Ja}$ & $\mathrm{Ja}$ & $\mathrm{Nej}$ & $\mathrm{Nej}$ & $\mathrm{Ja}$ & $\mathrm{Ja}^{5}$ & $\mathrm{Ja}$ \\
Apopleksi & $\mathrm{Ja}$ & $\mathrm{Ja}$ & $\mathrm{Neja}$ & $\mathrm{Nej}$ & $\mathrm{Nej}$ & $\mathrm{Ja}^{5}$ & $\mathrm{Ja}$ \\
Astma & $\mathrm{Nej}$ & $\mathrm{Ja}$ & $\mathrm{Nej}$ & $\mathrm{Nej}$ & $\mathrm{Nej}$ & $\mathrm{Nej}$ & $\mathrm{Ja}$ \\
Diabetes & $\mathrm{Ja}$ & $\mathrm{Ja}$ & $\mathrm{Nej}$ & $\mathrm{Ja}$ & $\mathrm{Nej}$ & $\mathrm{Ja}$ & $\mathrm{Ja}$ \\
Mental Health & $\mathrm{Ja}{ }^{1}$ & $\mathrm{Ja}^{2}$ & $\mathrm{Nej}$ & $\mathrm{Nej}$ & $\mathrm{Nej}$ & $\mathrm{Nej}$ & $\mathrm{Ja}^{6}$ \\
Generisk sygdom & $\mathrm{Nej}$ & $\mathrm{Nej}$ & $\mathrm{Nej}$ & $\mathrm{Nej}$ & $\mathrm{Nej}$ & $\mathrm{Nej}$ & \\
Tyktarmskræft & $\mathrm{Ja}$ & $\mathrm{Nej}$ & $\mathrm{Nej}$ & $\mathrm{Nej}$ & $\mathrm{Ja}$ & $\mathrm{Ja}$ & $\mathrm{Ja}$ \\
Endetarmskræft & $\mathrm{Ja}$ & $\mathrm{Nej}$ & $\mathrm{Nej}$ & $\mathrm{Nej}$ & $\mathrm{Ja}$ & $\mathrm{Ja}$ & $\mathrm{Ja}$ \\
Lungekræft & $\mathrm{Ja}$ & $\mathrm{Ja}$ & $\mathrm{Nej}$ & $\mathrm{Nej}$ & $\mathrm{Ja}$ & $\mathrm{Nej}$ & $\mathrm{Ja}$ \\
Brystkræft & $\mathrm{Ja}$ & $\mathrm{Ja}$ & $\mathrm{Nej}$ & $\mathrm{Nej}$ & $\mathrm{Ja}$ & $\mathrm{Nej}$ & $\mathrm{Ja}$ \\
Prostatakræft & $\mathrm{Nej}$ & $\mathrm{Ja}$ & $\mathrm{Nej}$ & $\mathrm{Nej}$ & $\mathrm{Ja}$ & $\mathrm{Ja}$ & $\mathrm{Ja}$ \\
Livmoderhalskræft & $\mathrm{Ja}$ & $\mathrm{Nej}$ & $\mathrm{Nej}$ & $\mathrm{Ja}$ & $\mathrm{Ja}$ & $\mathrm{Nej}$ & $\mathrm{Ja}$ \\
Melanom & $\mathrm{Ja}$ & $\mathrm{Ja}$ & $\mathrm{Nej}$ & $\mathrm{Nej}$ & $\mathrm{Ja}$ & $\mathrm{Ja}$ & $\mathrm{Ja}$ \\
\hline
\end{tabular}

Noter

1 Skizofreni NIP. Landsdækkende klinisk kvalitets-database for børn- og ungdomspsykiatri

$2 \mathrm{Ja}$, depression, emotionellt instabil personlighetsstörning, bipolär sjukdom, ätstörningar hos barn och ungdom, skitsofreni, posttraumatiskt stressyndrom, icke organisk sömnlöshet, beroendeförhållande orsakad av alkohol

3 Nej, forskningsregister

4 Nej forskningsregister

5 Nytt Nasjonalt hjerte- og karregister er vedtatt i Stortinget, vår 2010

6 Ja, psykosR og BipoläR 
Tabel 3. Oversigt over nationale registre for børn og unge

\begin{tabular}{|c|c|c|c|c|}
\hline Registerområder & Danmark & Finland & Færøerne & Grønland \\
\hline $\begin{array}{l}\text { Vaccinations- } \\
\text { programmer }\end{array}$ & $\mathrm{Ja}$ & Planer 1 & $\mathrm{Ja}$ & $\mathrm{Ja}$ \\
\hline \multirow{3}{*}{$\begin{array}{l}\text { Fødsler og } \\
\text { nyfødte }\end{array}$} & $\mathrm{Ja}$ & $\mathrm{Ja}$ & & $\mathrm{Ja}$ \\
\hline & $\begin{array}{l}\text { FØТO- } \\
\text { databasen }\end{array}$ & & & $\begin{array}{l}\text { Indgår i PKU- } \\
\text { registret }\end{array}$ \\
\hline & $\begin{array}{l}\text { Neonatalogisk } \\
\text { database }\end{array}$ & & & \\
\hline $\begin{array}{l}\text { Medfødte } \\
\text { lidelser }\end{array}$ & Nej & $\begin{array}{l}\text { Missbildnings- } \\
\text { register }\end{array}$ & & $\begin{array}{l}\text { Misdannelses- } \\
\text { registret }\end{array}$ \\
\hline Mor og barn & $\begin{array}{l}\text { Den nationale } \\
\text { fødselskohorte }\end{array}$ & Nej & & $\begin{array}{l}\text { Grønlandske børne- } \\
\text { kohorde }\end{array}$ \\
\hline Skoleelever & $\begin{array}{l}\text { 11-15 åriges } \\
\text { livsstil og sund- } \\
\text { hedsvaner }\end{array}$ & $\begin{array}{l}\text { Hälsoundersök-ning } \\
\text { bland skole-eleverna } \\
\text { 15-16 år }\end{array}$ & & $\begin{array}{l}\text { HBSC- } \\
\text { undersøgelsen }\end{array}$ \\
\hline \multirow[t]{3}{*}{ Tandsundhed } & $\begin{array}{l}\text { Centrale Odonto- } \\
\text { logiske Register } \\
\text { (SCOR) }\end{array}$ & $\begin{array}{l}\text { Hälso under sökning } \\
\text { bland åldersgrupp } \\
\text { 12, } 14,16 \text { och } 18 \text { år, } \\
\text { vart annat år }\end{array}$ & & $\begin{array}{l}\text { Register er under } \\
\text { opbygning }\end{array}$ \\
\hline & & + ESPAD och HBSC & & \\
\hline & & $\begin{array}{l}\text { Tandhälsa barn och } \\
\text { unge var } 3 \text {. År }\end{array}$ & & \\
\hline \multicolumn{5}{|l|}{ Obesitas } \\
\hline \multicolumn{5}{|l|}{$\begin{array}{l}\text { Gluten- } \\
\text { intolerans }\end{array}$} \\
\hline Cerebral parese & $\mathrm{Ja}$ & Nej & & $\begin{array}{l}\text { Register om gravide } \\
\text { vedr. cholestase } \\
\text { (CFG) og propionsy- } \\
\text { reæmi (PCCB) }\end{array}$ \\
\hline $\begin{array}{l}\text { Børne- og ung- } \\
\text { doms-psykiatri }\end{array}$ & $\mathrm{Ja}$ & Nej & & \\
\hline Kønssygdomme & & & & $\begin{array}{l}\text { Kønssygdoms- } \\
\text { statistik }\end{array}$ \\
\hline \multirow[t]{2}{*}{ Abort } & $\mathrm{Ja}$ & $\mathrm{Ja}$ & & $\mathrm{Ja}$ \\
\hline & $\begin{array}{l}\text { Abortregistret - } \\
\text { LPR }\end{array}$ & Abortregistret & & \\
\hline Cancer & & $\mathrm{Ja}$ & & \\
\hline \multicolumn{5}{|l|}{$\begin{array}{l}\text { Øre-, næse-, } \\
\text { halssygdomme }\end{array}$} \\
\hline $\begin{array}{l}\text { Læbe-, kæbe- } \\
\text { og ganespalte }\end{array}$ & & $\begin{array}{l}\text { Missbildnings- } \\
\text { register }\end{array}$ & & \\
\hline Diabetes & $\mathrm{Ja}$ & $\mathrm{Ja}$ & & $\mathrm{Ja}$ \\
\hline \multicolumn{5}{|l|}{$\begin{array}{l}\text { Hjertesygdom- } \\
\text { me }\end{array}$} \\
\hline
\end{tabular}

1 Der er planer for at starte et nationalt vaccinationsregister 
Tabel 4. Oversigt over nationale registre for børn og unge

\begin{tabular}{|c|c|c|c|}
\hline Registerområder & Island & Norge & Sverige \\
\hline $\begin{array}{l}\text { Vaccinations- } \\
\text { programmer }\end{array}$ & $\mathrm{Ja}$ & SYSVAK & $\begin{array}{l}\text { Vaccinationsstatistik } \\
\text { SMI }\end{array}$ \\
\hline \multirow[t]{2}{*}{$\begin{array}{l}\text { Fødsler og } \\
\text { nyfødte }\end{array}$} & Fødselsregistret & Medisinsk fødselsregister & $\begin{array}{l}\text { MFR-Medicinska } \\
\text { födelseregistret }\end{array}$ \\
\hline & Indgår i PKU-registret & $\begin{array}{l}\text { Nyfødtmedisinsk kvali- } \\
\text { tetsregister }\end{array}$ & PNQneonatal vård \\
\hline \multirow[t]{2}{*}{ Medfødte lidelser } & Anomaliregister & Medisinsk fødselsregister & $\begin{array}{l}\text { Register för tillväxthor- } \\
\text { monbehandling för barn }\end{array}$ \\
\hline & & $\begin{array}{l}\text { Register for arvelige og } \\
\text { medfødte nevromusku- } \\
\text { lære sykdommar }\end{array}$ & $\begin{array}{l}\text { Registret för övervak- } \\
\text { ning av fosterskador } \\
\text { och kromosomavvikel- } \\
\text { ser }\end{array}$ \\
\hline Mor og barn & & $\begin{array}{l}\text { Den nationale fødselsko- } \\
\text { horte }\end{array}$ & $\begin{array}{l}\text { MFR-Medicinska } \\
\text { födelseregistret } \\
\text { Amning under barnets } \\
\text { första } 12 \text { månader } \\
\text { Rökning bland späd- } \\
\text { barnsföräldrar } \\
\text { Kvalitetsregister för } \\
\text { Mödrahälsovård } \\
\text { CP-uppföljnings- } \\
\text { programmet (CPUP) }\end{array}$ \\
\hline Cerebral parese & & $\mathrm{Ja}$ & \\
\hline Skoleelever & $\begin{array}{l}\text { Hälsoundersökning } \\
\text { bland skoleeleverna }\end{array}$ & & \\
\hline Tandsundhed & $\begin{array}{l}\text { Tandhälsa barn og } \\
\text { unge }\end{array}$ & & \\
\hline Obesitas & & & $\begin{array}{l}\text { BORIS (Barn- } \\
\text { ObesitasRegister) }\end{array}$ \\
\hline Glutenin-tolerans & & & $\begin{array}{l}\text { Glutenintoleransregister } \\
2\end{array}$ \\
\hline $\begin{array}{l}\text { Børne- og ung- } \\
\text { domspsykiatri }\end{array}$ & & & $\begin{array}{l}\text { RIKSÄT Kvalitets- } \\
\text { register för ätstörningar } \\
\text { BUSA-kvalitetsregister } \\
\text { för behandlingsupp- } \\
\text { följning av svår ADHD } \\
\text { SÖK Kvalitetsregister } \\
\text { för barn och ungdomar } \\
\text { som miss- } \\
\text { tänkts/konstaterats blivit } \\
\text { utsatta }\end{array}$ \\
\hline \multicolumn{4}{|l|}{ Kønssygdomme } \\
\hline Abort & Abortstatistik & Abortregistret & Abortstatistik \\
\hline Cancer & Cancerregistret & $\begin{array}{l}\text { Nordic Solid Tumours in } \\
\text { children (NOPHO) } \\
\text { Cancerregistret }\end{array}$ & \\
\hline $\begin{array}{l}\text { Øre-, næse-, } \\
\text { halssygdomme }\end{array}$ & & & $\begin{array}{l}\text { Kvalitetsregister för } \\
\text { Öron-, näs- och hals- } \\
\text { sjukvård }\end{array}$ \\
\hline $\begin{array}{l}\text { Læbe-, kæbe- og } \\
\text { ganespalte }\end{array}$ & & & $\begin{array}{l}\text { LKG (Läpp, käk, gom- } \\
\text { spalt) - register } 3\end{array}$ \\
\hline
\end{tabular}




\begin{tabular}{llll}
\hline Registerområder & Island & Norge & Sverige \\
\hline & & & Fortsat..... \\
Diabetes & Nej & $\begin{array}{l}\text { Medisinsk kvalitets- } \\
\text { register for barne- og } \\
\text { ungdomsdiabetes }\end{array}$ & NDR-barn (SWEDIAB- \\
& & KIDS) børn med diabe- \\
& & tes \\
Hjertesygdomme & & SWEDCON-register för \\
& & medfödda hjärtsjuk- \\
Kroniske syg- & & dommar 4 \\
domme & & Register för barn och \\
& & ungdommar kroniska \\
& & sjukdommar 5 \\
& & Svenska Barnreumare- \\
& & gistret \\
\hline
\end{tabular}

2 Forskningsregister. Omfatter både barn och unga

3 Omfatter samtliga födda barn med LKG och deras operationer sedan

4 Registret är en sammanslagning av det tidigare GUCH-registret över vuxna med medfödda hjärtfel, lokala barnkardiologiska register samt den barnhjärtkirurgiska delen av svenska hjärtkirurgiregistret. Det nya registret kommer nu att följa patienter med medfödd hjärtsjukdom från födelsen och genom hela livet. Det kommer även innefatta genomgången kirurgi

5 Barn med kronisk sjukdom utgör de flesta och mest resurskrävande patienterna inom barnsjukvården. De kroniska sjukdomarna kan leda till funktionshinder o sänkt livskvalitet. Då de kan vara livslånga är det särskilt viktigt att redan $\mathrm{i}$ barnaåren erbjuda vård som är säker och av hög kvalitet för bästa möjliga resultat

Tabel 5. Oversigt over nationale kliniske retningslinjer for børn og unge

\begin{tabular}{|c|c|c|c|c|c|c|c|}
\hline $\begin{array}{l}\text { Kliniske } \\
\text { retningslinjer }\end{array}$ & Danmark & Finland & Færøerne & Grønland & Island & Norge & Sverige \\
\hline Diabetes & & Nej & Nej & $\mathrm{Ja}$ & Nej & $\mathrm{Ja}$ & \\
\hline $\begin{array}{l}\text { Syn/hørelse/ } \\
\text { sprog }\end{array}$ & & Nej & Nej & $\mathrm{Ja}$ & $\mathrm{Ja}$ & $\mathrm{Ja}$ & \\
\hline Svangerskab & $\mathrm{Ja}$ & Nej & Nej & $\begin{array}{l}\text { Perinatal } \\
\text { sundhed }\end{array}$ & $\mathrm{Ja}$ & $\mathrm{Ja}$ & Ja 1 \\
\hline Vaccinationer & $\mathrm{Ja}$ & & $\mathrm{Ja}$ & $\mathrm{Ja}$ & & & $\mathrm{Ja}$ \\
\hline $\begin{array}{l}\text { Hjerte- } \\
\text { sygdom }\end{array}$ & & $\mathrm{Nej}$ & $\mathrm{Nej}$ & & & & $\begin{array}{l}\text { För med- } \\
\text { födda } \\
\text { hjärtfel }\end{array}$ \\
\hline
\end{tabular}

1 Ej myndighetsriktlinje. Basprogram för vård under graviditet, utarbetat i ett samarbete mellan professionerna Svenska Barnmorskeförbundet (SBF) och Svensk förening för obstetrik och gynekologi (SFOG) 
Tabel 6. Oversigt over nationale screeningsprogrammer

\begin{tabular}{|c|c|c|c|c|c|c|c|}
\hline Sygdom & Danmark & Finland & Færøerne & Grønland & Island & Norge & Sverige \\
\hline Brystkræft & $\mathrm{Ja}$ & $\mathrm{Ja}$ & Genetisk screening & Nej & $\mathrm{Ja}$ & $\mathrm{Ja}$ & $\mathrm{Ja}$ \\
\hline $\begin{array}{l}\text { Livmoder- } \\
\text { halskræft }\end{array}$ & $\mathrm{Ja}$ & $\mathrm{Ja}$ & $\mathrm{Ja}$ & $\mathrm{Ja}$ & $\mathrm{Ja}$ & $\mathrm{Ja}$ & $\mathrm{Ja}$ \\
\hline $\begin{array}{l}\text { Retinopati og } \\
\text { maculopati }\end{array}$ & $\mathrm{Ja}$ & Nej & Nej & Nej & Nej & Nej & $\mathrm{Ja}$ \\
\hline
\end{tabular}

Tabel 7. Oversigt over nationale screeningsprogrammer for gravide og nyfødte

\begin{tabular}{llllllll}
\hline Screening & Danmark & Finland & Færøerne & Grønland & Island & Norge & Sverige \\
\hline Under graviditet & $\mathrm{Ja}$ & $\mathrm{Ja}^{123}$ & $\mathrm{Nej}$ & $\mathrm{Ja}^{5}$ & $\mathrm{Ja}^{6}$ & $\mathrm{Ja}^{7}$ & $\mathrm{Ja}^{8}$ \\
Af nyfødte & $\mathrm{Ja}$ & $\mathrm{Ja}^{4}$ & $\mathrm{Ja}$ & $\mathrm{Ja}$ & $\mathrm{Ja}$ & $\mathrm{Ja}$ & $\mathrm{Ja}$ \\
\hline
\end{tabular}

Noter

1 a) allmän ultraljudsundersökning under tidig graviditet i graviditetsvecka 10+0-13+6

2 b) utredning av kromosomavvikelser i första hand genom kombinerad screening under tidig graviditet (tidig graviditet serumscreening i graviditetsvecka 9+0-11+6 och mätning av nackuppklarning i samband med den allmänna ultraljudsundersökningen i graviditet

3 c) ultraljudsundersökning för att utreda grava anatomiska avvikelser i graviditetsvecka 18+0-21+6 eller efter graviditetsvecka $24+0$

4 Hypotyreos, för tillfälle PKU enbart för riskgrupper

5 Register for undersøgelse af gravidefor anlægsbærertilstand for cholestase (CFG) og propionsyreæmi (PCCB), diabetes, kønssygdomme, nyresygdom, blodtryk etc.

6 Ultraljud med nackuppklarningsundersökning sk NUPP samt biokemiskt test som är en skattning av sannolikheten för att fostret ska ha Downs syndrom

7 Ultralyd-screening i 16-18 uke. Screening for Down Syndrom etter visse kriterier.

8 Ultraljudsscreening i graviditetsvecka 16-18 (kolla i blå boken) Vissa landsting erbjuder KUB test till kvinnor över en viss ålder eller vid oro

Ultraljud. KUB-test i vissa landsting (Ultraljud med nackuppklarningsundersökning sk NUPP samt biokemiskt test)som är en skattning av sannolikheten för att fostret ska ha Downs syndrom

Basprogram för vård under graviditet är framtaget i samarbete mellan professionerna Barnmorskeförbundet/SFOG) och ger rekommendationer över antal besök hos barnmorska/Jordmor och läkare mm. Här finns också screening för graviditetsdiabetes, och flera andra undersökningar som görs för att diagnostisera komplikationer under graviditet

Tabel 8. Forebyggelse og sundhedsfremme - oversigt over nationale registre for levevaner

\begin{tabular}{lllllll}
\hline Danmark & Finland & Færøerne & Grønland & Island & Norge & Sverige \\
\hline Sund- & AVTK varje år. & Nationale & Befolk- & Nationale. & Nationale. & Folkhäl- \\
heds- & Hälso-beteende & spørge- & ningsus & spørge- & spørge- & so- \\
profiler, & bland, vuxenbe- & skemaus. & $>17$ år & skemaus. & skemaus. & enkäter \\
hvert år & folkning ${ }^{1,2,3,4,5,}$ & & & & & \\
\hline
\end{tabular}

Noter

1 Hälsoundersökningsstudier ca. var 10 år (2000 2011-2012)

2 European Health Interview Survey 2014

3 Pilot av European Health Examination Survey 2010-11

4. Hälsoundersökning bl. skolelever 15-16 år, varje år

5 Hälsoundersökning bl. åldergrupp 12, 14, 16 och 18 år, vartannat år 


\section{Bilag 4.}

Generiske og sygdomsspecifikke kvalitetsindikatorer

Danmark

Lovgrundlag for indsamling og offentliggørelse af data, som belyser kvaliteten af sundhedsvesenets ydelser

Sundhedsloven nr. 546 af 4. juni 2005 ligger til grund for regler om indsamling og offentliggørelse af data i sundhedsvæsenet. Sundhedslovens § 195 omhandler regionernes, kommunernes og privat praktiserende sundhedspersoners indberetning af helbredsoplysninger til centrale sundhedsmyndigheder. Det er på baggrund af denne paragraf i Sundhedsloven, at Sundhedsstyrelsen har hjemmel til at drive bl.a. Landspatientregisteret (LPR). Reglerne for indberetning af data til LPR fastlægges i praksis af "Koordinationsgruppen for individbaseret patientregistrering".

Endvidere fastslår ”Bekendtgørelse om lægers anmeldelse til Sundhedsstyrelsens Landspatientregister af patienter behandlet på private sygehuse eller klinikker” (Bekendtgørelse nr. 1073 af 6. september 2007), at private sygehuse og klinikker er forpligtede til at indberette oplysninger om lægelig behandling af patienter til LPR.

Lovgrundlag for nationale kvalitetsdata og kvalitetsregistre i sundhedsveesenet

Som lovgrundlag for nationale kliniske kvalitetsdatabaser og kvalitetsregistre gælder Bekendtgørelse af 1. januar 2007 om indberetning af oplysninger til kliniske kvalitetsdatabaser. I § 3. er det anført, at regionsråd, kommunalbestyrelser, private personer og institutioner, der driver sygehuse, samt praktiserende sundhedspersoner, har pligt til at indberette oplysninger til landsdækkende kliniske kvalitetsdatabaser, samt til andre kliniske kvalitetsdatabaser efter nærmere af Sundhedsstyrelsen fastsatte regler.

Gceldende krav for nationale kvalitetsregistre og - databaser

Krav til indberetning til nationale kliniske kvalitetsdatabaser og -registre er fastsat i Bekendtgørelse om godkendelse af landsdækkende og regionale kliniske kvalitetsdatabaser (15. juni 2006). Kravene omhandler bl.a., at regionsråd, kommunalbestyrelser, private personer og institutioner, der driver sygehuse, samt praktiserende sundhedspersoner har pligt til at sikre indbe- 
retning af oplysninger til de landsdækkende og de regionale kliniske kvalitetsdatabaser, som er godkendt af Sundhedsstyrelsen.

Indberetningspligten indebærer, at oplysninger, som kan henføres til bestemte personer, kan videregives til den kliniske kvalitetsdatabase uden samtykke fra personen.

Krav er ligeledes, at den kliniske kvalitetsdatabase årligt skal offentliggøre data om behandlingskvaliteten opgjort på den relevante organisatoriske enhed, opgjort efter anerkendte statistiske metoder. I bilag 5 ses oversigt over danske godkendte nationale kvalitetsdatabaser.

Kvalitetsdata offentliggøres på: Sundhed.dk, Sundhedskvalitet.dk, Sundhedsdata.sst.dk

\section{Lovbundne hindringer for offentliggørelse af data}

Sundhedsstyrelsen må ikke offentliggøre personhenførbart data om en identificerbar fysisk person (den registrerede). Dette gælder også for indberetninger vedr. utilsigtede hændelser, hvor Bekendtgørelsen af 21. maj 2007 siger i § 7., at rapporteringen til Sundhedsstyrelsen skal ske i anonymiseret form. Rapporteringen må ikke indeholde navne, adresser, personnumre eller lignende oplysninger, som umiddelbart giver mulighed for at identificere de involverede sundhedspersoner og patienter.

Lov om behandling af personoplysninger (Persondataloven af 31.5.2000) omhandler den dataansvarliges behandling af personoplysninger. Sundhedsstyrelsen er dataansvarlig i forbindelse med LPR.

For Sundhedsstyrelsens behandling af helbredsoplysninger gælder bestemmelserne i Persondataloven $\S \S 41,42$ og 69.

\section{Grønland}

Lovgivningsmæessigt grundlag for datatilgæengeligheden af sundhedsdata. Grønland har endnu ikke vedtaget sin egen registerlov. Grundlaget for sundhedsvæsenet statistik og registre er fortsat den danske registerlov fra 1980'erne. Det forventes, at det grønlandske Landsting kan vedtage en persondatalov ved efterårssamlingen i 2010. Denne skal senere følges op med yderligere lovgivning, der skal give retningslinjer for, hvordan relevant information kan videregives mellem myndigheder og dermed sikre en optimal servicering af borgerne. 
Det er således endnu ikke helt klarlagt hvordan grundlaget for datatilgængelighed af sundhedsdata bliver i fremtiden, men den nye persondatalov forventes i alt væsentligt at blive identisk med dansk lovgivning på området.

Der er for nuværende ingen lovgivningsmæssige forskrifter, der efter tilladelse hindre registrering af patientdata til statistisk brug.

Finland

Lagstiftning för datainsamling och publicering av information om hälsovårdens kvalitet

Det finska hälsoinformationssystemet baserar på detaljerad registerdata, som samlas in på individnivån med personnummer. Finlands tre viktigaste myndigheter, som samlar in hälsovårdens registerdata är: 1) THL Institutet för hälsa och välfärd, 2) FPA Folkpensionsanstalten och 3) Statistikcentralen.

Enligt lag och förordning om riksomfattande personregister för hälsovården (556 \& 774/1989) har THL och vissa andra hälsomyndigheter rätt att samla in data i sina centralregister som berör hela landet och som innehåller uppgifter om hälsotillstånd, sjukdom eller handikapp eller om vårdåtgärder. THL har rätt att samla in de följande register: 1) cancerregister (sedan 1952), 2) missbildningsregister (sedan 1963), 3) hälsovårdens vårdanmälningsregister (bäddavdelningsvård sedan 1967, dagkirurgi sedan 1994 poliklinikbesök i specialiserad sjukhusvård sedan 1998), 4) massundersökningsregister (screening för livmoderhalsens cancer sedan 1968 och screening för bröstcancer sedan 1987, pilotundersökningar om prostatacancer och tarmcancer är på gång), 5) abort- och steriliseringsregister (sedan 1977), 6) implantatregister (höft- och ledproteser sedan 1980 och tandimplantater sedan 1994), 7) synskaderegister (sedan 1983), 8) födelseregister (sedan 1987), och 9) register över smittsamma sjukdomar (sedan 1989 i sitt nuvarande format).

Registerdata kan användas för statistikföring, planering, forskning och tillsyn, men uppgifter ur riksomfattande personregister får inte användas för beslut som gäller den registrerade. Hälsovårdsmyndigheterna, hälsovårdsanstalterna och hälsovårdspersonalen är skyldiga att ur handlingar och register avgiftsfritt lämna de uppgifter som införs i personregister. Den registrerade personens samtycke krävs inte.

För hälsovårdens kvalitetsindikatorer används mest hälsovårdens vårdanmälningsregister, massundersöknings- och cancerregister samt födelseregister. Implantatregistret är det ända register, vars primära syfte är kvalitetssäkring. 
Folkpensionsanstalten är ansvarig för administration av hälsorelaterade förmåner, som är till exempel relaterade till långvarig sjukdom och handikapp. Den mest använda information för kvalitetsindikatorer inom hälsovården är register över specialersättning för läkemedel - som angår vissa sjukdomar t.ex. diabetes, epilepsi och astma - samt information om receptpliktiga läkemedel, som ersätts av den allmänna sjukförsäkringen.

Denna information finns i registerformat sedan 1964 och 1994, respektive. Statistikcentralen har ansvarat för dödorsaksregister sedan 1936, och informationen är i registerformat sedan 1969. Denna registerinformation behövs i synnerhet för att få tillförlitlig information om cancerdödligheten och överlevnadstal efter cancerdiagnos samt om dödlighet i samband med vissa sjukdomar, t.ex. astma, hjärtinfarkt och stroke.

Cancerregister kan rutinmässigt sammankoppla information om dödsfall och dödsorsaker till sitt register, men kontinuerlig sammankoppling av denna information är inte möjlig för utskrivningsregister. Detta innebär att det inte är möjligt att ta fram all dödlighet efter vissa sjukdomar, utan Finland kan presentera enbart sjukhusdödligheten.

\section{Juridiska och andra problem angående kvalitetsregister}

Finland har färre kvalitetsregister än de andra nordiska länderna. En orsak är att inget nytt riksomfattande register kan grundas utan förändringar i lagstiftningen. Utanför statsförvaltning, vanligen på universitetssjukhusen finns det ett antal kvalitetsregister, t.ex. om njursjukdomar och om behandlingar med biologiska läkemedel.

Dessa register kan samlas in enbart med patientens samtycke. Dessa kvalitetsregister har sällan en hållbar finansiering och användning av registerdata i statistik och forskning kan vara svårt på grund av registrens oofficiella status. Hela lagstiftningen om hälsoregister skall förnyas på 2010-talet, men denna process antas ta många år. Det är fortfarande oklart, om kvalitetsregister skall inkluderas i det nya laget.

Ett annat problem är att sammankoppling av registerdata från olika institutioner kan vara komplicerad. Administrativt ligger THL under social- och hälsoministeriet, Statistikcentralen under finansministeriet och FPA kontrolleras direkt av riksdagen. Detta innebär att alla tre institutioner kräver sitt eget tillstånd för användning av register i forskning och statistikföring. Myndigheterna kan med avtal byta registerinformation för sina egna uppgifter, men enligt dataskyddsombudsman kan dessa sammankopplingar inte 
forma ett nytt register utan att förnya lagstiftningen. Detta gäller även inkludering av nya variabler som inte samlas in i register från originalkällan.

Finland har samlat in enbart aggregerad information om primärvården och dess funktioner, och information om diagnoser samt åtgärder saknas på nationellt nivå. År 2010 startade THL ett pilotprojekt för att samla in information om alla besök till hälsovårdscentralen på personnivå. Från och med 1 januari 2011 skall alla finska hälsovårdscentralen delta i datainsamlingen. Detta utvidgar avsevärt möjlighet för bättre information om de sjukdomar (t.ex. diabetes) och komplikationer som vårdas i primärvården.

Island

Hvilke lovgrundlag er der for indsamling og offentliggørelse af data, som belyser kvaliteten af sundhedsvcesenets ydelser?

Sundhedsloven nr. 40/2007 og loven om landslægen nr. 41/2007 ligger til grund for regler om indsamling og offentliggørelse af data i sundhedsvæsenet. Sundhedslovens kapitel VI omhandler landslægens rolle angående kvalitet i sundhedsvæsenet. I loven om landslægen $\S 7$ er belysning af hans rolle angående monitoring af kvaliteten i sundhedsvæsenet og institutionernes og sundhedspersoners pligt til indberetning af helbredsoplysninger til landslægen. I § 8 er belysning af hans pligt til at indsamle data angående helsetilstand, sygdomme, medicin, fødsler og om sundhedsvæsensets virksomhed og resultat. Paragraf 9. omhandler landslægens pligt til at holde register over utilsigtede hændelser. Det er på baggrund af denne paragraf i loven om landslægen, at han skal drive visse registre. Landslægen har udgivet anmodning om institutioners og privat praktiserende læger pligt til at anmelde minimum oplysninger om patientens behandling og forløb. I loven om statsepidemiologen nr. 19/1997 er í § 5 belysning af hans pligt til at holde register om smitsomme sygdomme og vaccinationer. Bekendtgørelse nr. 420/2008 handler om register om smitsomme sygdomme og bekendtgørelse nr. 221/2001 handler om register om vaccinationer.

Hvilke lovgrundlag eksisterer der for nationale kvalitetsdata og kvalitetsregistre i sundhedsveesenet?

Som lovgrundlag for nationale kliniske kvalitetsdatabaser og kvalitetsregistre gælder loven om landslægen nr. 41/2007 paragraf 8 og bekendtgørelse nr. 548/2008. I loven om statsepidemiologen nr. 19/1997 er í § 5. belysning af hans pligt til at holde register om smitsomme sygdomme. Bekendtgørelse 
nr. 221/2001 paragraf 1 omhandler statsepidemiologens pligt til at holde register om vaccinationer.

Disse lover og bekendtgørelse handler om intitutioners og sundhedspersonnels pligt til at indberette oplysninger til landslægens og statsepidemiologens databaser og registre efter nærmere fastsatte regler.

Hvilke krav geelder for nationale kvalitetsregistre og - databaser?

Krav til indberetning til nationale kliniske kvalitetsdatabaser og -registre er fastsat i loven om landslægeren nr. 41/2007 paragraf 8, bekendtgørelse nr. 548/2008, loven om statsepidemiologen nr. 19/1997 og bekendtgørelse nr. 221/2001.

Er der lovbundne hindringer for offentliggørelse af data?

Landslægen og statsepidemiologen må ikke offentliggøre personhenførbart data om en identificerbar fysisk person (den registrerede). Lov om personværn og behandling af personoplysninger nr. 77/2000 omhandler den dataansvarliges behandling af personoplysninger.

De vigtigeste databaser og register (engelsk)

Primary health care, Hospitals (discharge data), Centralized accident registry, Waiting lists, Communicable diseases, Vaccinations, Birth records, Sterility operations, Abortions, Mortality record, Cancer registry, Prescriptions \& pharmacovigilance, Complaint

\section{Norge}

Hvilke lovgrunnlag er det for innsamling og offentliggjøring av data som belyser kvaliteten på tjenestetilbudet i helsetjenesten?

Kvalitetsdata brukes i Norge om et utvalg av indikatorer som velges ut fra de samlede data som er tilgjengelige i landets sentrale og regionale helseregistre. Kvalitetsindikatorer skal fortelle noe om kvaliteten i helsetjenesten. Dataene framkommer ved bearbeiding og sammenstilling av helseopplysninger som er samlet inn i medhold av helseregisterloven (Lov om helseregistre og behandling av helseopplysninger (helseregisterloven) av 18. mai $2001 \mathrm{nr}$ 24) og en rekke forskrifter som er fastsatt i medhold av loven.

Forskrift om innsamling og behandling av helseopplysninger i Norsk pasientregister (NPR forskriften) av 12. juli $2007 \mathrm{nr} 1389$ gir et viktig grunnlag i arbeidet med å utvikle kvalitetsindikatorer for spesialisthelse-tjenesten. 
Som databehandlingsansvarlig for NPR registeret er Helsedirek-toratet ansvarlig for at det publiseres statistikk og analyser slik at registeret blir brukt $\mathrm{i}$ henhold til formålet. Hovedformålet med NPR er blant annet å danne grunnlag for kvalitetssikring av spesialisthelsetjenester. Det er ikke spesifisert i lov/forskrift hvilke kvalitetsdata som skal offentliggjøres. De kvalitetsdata som offentliggjøres er dermed valgt på faglig grunnlag ut fra en vurdering av at disse data vil være hensiktsmessig for å oppnå formålet. Det arbeides kontinuerlig for å forbedre dataene.

I Norge er det i hovedsak utviklet kvalitetsdata for to målgrupper; 1. Pasient/brukere og 2. Helsepersonell/helseforvaltning. Kvalitetsdata for pasient/brukere er offentlig tilgjengelig på nettsiden "Fritt sykehusvalg”. Kvalitetsdata for helsepersonell/helseforvaltning er offentlig tilgjengelig på Helsedirektoratets nettsider under overskriften Kvalitetsindikatorer. I hovedsak er det bare offentliggjort kvalitetsdata for spesialisthelsetjenesten.

Hvilket lovgrunnlag eksisterer for nasjonale kvalitetsdata og kvalitetsregistre i helsetjenesten

Helseregisterloven gir lovgrunnlag for arbeidet med nasjonale kvalitetsdata og medisinske kvalitetsregistre. Helseregisterloven § 9 er hjemmel for innsamling av helseopplysninger til sentrale, regionale, lokale og behandlingsrettede helseregistre i den utstrekning det er fastsatt i forskrift eller følger av helseregisterloven $\S 9$. Virksomheter som er omfattet av helseregisterloven § 9 har meldeplikt i forhold til de opplysninger som det er fastsatt at de skal melde inn. For Norsk pasientregister (NPR) er plikten til innsending av helseopplysninger fastsatt i NPR forskriften § 2-1.

Plikt til å pålegge virksomheter innrapportering av data til statistikk kan også pålegges virksomheter som yter helsetjenester i forskrift eller ved enkeltvedtak etter helseregisterloven § 10. Opplysningene innrapporteres avidentifisert eller anonymt.

Helsepersonelloven (lov om helsepersonell m.v. (helsepersonelloven) av 2. juli $1999 \mathrm{nr} 64$ gir videre i § 37 hjemmel for å pålegge helsepersonell med lisens eller autorisasjon å gi opplysninger til helseregistre i samsvar med forskrift gitt i medhold av helseregisterloven. Dette innebærer at helseopplysninger skal meldes uavhengig av den taushetsplikt helsepersonellet har som profesjonsutøvere. 
Medisinske kvalitetsregistre har ikke noen spesifikk forankring i helseregisterloven. Slike registre er opprettet med hjemmel i helseregisterloven § 7 andre ledd og $\S 8$ andre ledd og er som hovedregel basert på samtykke.

Sentrale helseregistre og medisinske kvalitetsregistre er under utredning med sikte på en modernisering for å sikre bedre utnyttelse, bedre kvalitet og enda mer sikker håndtering av data i registrene. En hovedrapport om Gode helseregistre - bedre helse ble avgitt fra Helse- og omsorgsdepartementet 21. desember 2009. Rapporten har vært på høring og er nå under behandling i departementet.

Hvilket krav gjelder for kvalitetsregistre og kvalitetsdatabaser

Se omtalen ovenfor.

Er det lovbundne hindringer for offentliggjøring av data

Helsedirektoratet kan ikke offentliggjøre data som kan henføres til enkeltpersoner eller som kan gi risiko for bakveisidentifisering av personer som det er registrert opplysninger om. Det betyr at data som offentliggjøres må være anonyme. Det legges til grunn at opplysningene først kan anses som anonyme dersom de kan knyttes til en av fire eller fem individer. NPR forskriften fastslår i § 4-1 at enhver som behandler helseopplysninger etter forskriften, har taushetsplikt etter helseregisterloven $\S 15$. Data i NPR registeret må brukes innenfor de rammer forskriften setter. I bilag 6 ses nasjonale medisinske kvalitetsregistre i Norge.

\section{Referencer}

2001.12.21 nr 1476: (HOD)Forskrift om innsamling og behandling av helseopplysninger i Dødsårsaksregisteret (Dødsårsaksregisterforskriften)

2001.12.21 nr 1477: (HOD)Forskrift om innsamling og behandling av helseopplysninger i Kreftregisteret (Kreftregisterforskriften)

2001.12.21 nr 1483: (HOD)Forskrift om innsamling og behandling av helseopplysninger i Medisinsk fødselsregister (Medisinsk fødselsregisterforskriften)
2003.06.20 nr 0739: (HOD)Forskrift om innsamling og behandling av helseopplysninger i Nasjonalt vaksinasjonsregister (SYSVAK-registerforskriften) 2003.06.20 nr 0740: (HOD)Forskrift om innsamling og behandling av helseopplysninger i Meldingssystem for smittsomme sykdommer og i Tuberkuloseregisteret og om varsling om smittsomme sykdommer (MSIS- og Tuberkuloseregisterforskriften) 
2003.10.17 nr 1246: (HOD)Forskrift om innsamling og behandling av helseopplysninger i Reseptbasert legemiddelregister (Reseptregisteret).

2003.11.14 nr 1353: (HOD)Forskrift om innsamling og behandling av helseopplysninger i Norsk overvåkingssystem for antibiotikaresistens hos mikrober (NORM-registerforskriften). 2005.02.04 nr 0080: (HOD)Forskrift om tapping, testing, prosessering, oppbevaring, distribusjon og utlevering av humant blod og blodkomponenter og behandling av helseopplysninger i blodgiverregistre (blodforskriften). 2005.06.17 nr 0611: (HOD)Forskrift om innsamling og behandling av helseopplysninger i Norsk overvåkingssystem for infeksjoner i sykehustjenesten (NOIS-registerforskriften).

2005.09.02 nr 1010: (FD)Forskrift om innsamling og behandling av opplysninger i Forsvarets helseregister. 2006.02.17 nr 0204: (HOD)Forskrift om pseudonymt register for individbasert pleie- og omsorgsstatistikk.
2007.12.07 nr 1389: (HOD)Forskrift om innsamling og behandling av helseopplysninger i Norsk pasientregister (Norsk pasientregisterforskriften)

2007.12.14 nr 1418: (HOD)Forskrift om innsamling og behandling av helseopplysninger i register over svangerskapsavbrudd (abortregisterforskriften)

2007.12.21 nr 1573: (HOD)Forskrift om varsling av og tiltak ved alvorlige hendelser av betydning for internasjonal folkehelse (IHR-forskriften)

2007.12.21 nr 1610: (HOD)Forskrift om behandling av helseopplysninger i nasjonal database for elektroniske resepter (Reseptformidlerforskriften)

2008.03.07 nr 0222: (HOD)Forskrift om krav til kvalitet og sikkerhet ved håndtering av humane celler og vev

2008.08.04 nr 0878: (HOD)Forskrift om unntak fra rekvirents meldeplikt til Reseptformidleren

2009.12.18 nr 1639: (HOD)Forskrift om behandling av helseopplysninger i

Egenandelsregisteret (egenandelsregisterforskriften)

2009.12.18 nr 1640: (HOD)Forskrift om registre for administrering og samordning av syketransport (syketransportregisterforskriften)

\section{Sverige}

\section{Swedish rules regarding person identifiable health information}

The applicable Swedish legislation includes the Freedom of the Press Act, Chapter 2 (defining public documents), the The Public Access to Information and Secrecy Act, (2009:400), the Person Data Act (1998:204), the Health Data Act (1998:543), the Official Statistics Act (2001:99), the EC Regulation on Community Statistics 322/97, and the Directive 95/46/EC of the European Parliament.

\section{Data collection}

In general, person identified information can be collected and stored only after the explicit informed consent of the individual. 
Person identified health information has been considered particularly important as well as particularly sensitive. Therefore, in addition to the rules that follow from the EU directive on person identified data 95/46/EC, Sweden has special legislation for health data. The main act regulating the collection and use of health data is the Health Data Act.

Currently the rules permit and prescribe the collection of person identified information by central government authorities (i.e. The National Board of Health and Welfare) without acquiring the consent from the individual. This means that all health care providers have to deliver specified health data to the government. The allowable information which can and must be collected is described in detail in special directives attached to the legislation.

At regular intervals the authorities must inform the general public about the existence and content of the person identified registries, for example by announcements in news media. The individual can always get excerpts from the registry containing his or her own information, and can have erroneous information in the registries corrected.

Data can also be collected based on the Official Statistics Act. This can be done in a mandatory or voluntary survey, but data for the production of statistics can also be collected from registers. Non-voluntary data collected for statistical purposes (i.e. based on mandatory rules such as a census), or data which are given voluntarily (such as in a public health survey), may in principle be used only for the production of statistics.

Confidentiality and data protection

Special legislation for health data

Sweden distinguishes between person identified information in general and sensitive person identified information. Health information is classified as sensitive information, and is protected by a particularly strong secrecy requirement.

Because of this, Sweden has a separate legislation for health data. The Health Data Act contains basic rules for the collection of health data as well as fundamental requirements for the processing of it. There are limitations on how and when the data can be used, and there are rules about which authorities, organisations and/or individuals that can get access to the data. According to these rules, person identified health data can only be used for research, statistics, and follow-up of health care. 
The principles of public disclosure and confidentiality

In addition to the health data legislation there are rules about disclosure of public information and about data confidentiality. This legislation is applicable regardless of whether the information is collected on the basis of the Health Data Act or the Official Statistics Act.

In general, all the information kept by Swedish public authorities is public property and must be shared with the general public upon request, unless there are special reasons to keep the information secret. This is the principle of public disclosure which ensures the transparency of public affairs, a basic requirement of a democratic society.

But there are some important limitations to the general rule. Much of the information that can be tied to an individual (person identified) and may prove potentially harmful if disclosed is protected from disclosure by privacy legislation ("secrecy"). This is regulated in the the The Public Access to Information and Secrecy Act.

Any information which concerns personal or economical circumstances is confidential if it is collected by a public authority dealing with the production of statistics. Information needed for statistics or research purposes, and information which is not directly related to the private subject, may however be disclosed if it is evident that the information can be released without loss or harm for the person whom the information concerns.

The Public Access to Information and Secrecy Act does not contain any general rule concerning confidentiality when data are transferred between public authorities. The general rule is that whenever data are transferred the confidentiality rules of the recipient authority will be applied. However, in some special situations the rules provide for a transfer of the original secrecy rule along with the data. One of these situations occurs if an authority receives confidential data for research purposes from another authority. In this case the original confidentiality will apply also within the receiving authority. In practice this means that access to micro data can be given for the purpose of research in public authorities, e.g. universities, whenever this is necessary for the research. No such rule exists concerning the release of data for statistical purposes or public planning.

In order to use person identified health data for research, Swedish law requires that the research must be approved by an ethics committee. The ethics committee can either require that the researcher obtains actual approval to use the data from the research subjects, or it can replace the in- 
formed consent of the individual by a committee approval if the research is considered to be of great importance for society.

Once approval to use the data is obtained from an ethics committee, the statistical authority (Centre for Epidemiology, National Board of Health and Welfare) will in a second step try whether the release of the person identified health data is associated with any risk that disclosure will harm the individual. The main legal basis for this trial is the The Public Access to Information and Secrecy Act. The basic rule applicable to sensitive information is that data can only be released if it is clear beyond reasonable doubt that disclosure is not harmful. In addition, the research must be of great general value. Anonymous data will be released unless person identified information is absolutely necessary in order to perform the research.

Although no permission from an ethics committee is needed, the second step (applying the restrictions prescribed in the Secrecy Act) is carried out also when information is released for the production of statistics.

If released, the data are provided with instructions to the user to keep the data safe, not share it with others without prior permission from the statistical authority, and destroy it when the research has been completed or when it is no longer necessary for the project.

Person identified health data at EpC

The great benefits of person identified health information have been well documented in Swedish public health reporting and in epidemiological, social, and public health research extending far beyond the Swedish setting. The booklet "A Finger on the Pulse. Monitoring public health and social conditions in Sweden 1992-2002” (2003) describes the Swedish experience quite well (attached).

The person identified health registries are kept in a separate division of the National Board of Health and Welfare, The Centre for Epidemiology (EpC). Only a handful of the staff within this division has access to person identified data. The physical and virtual security and data protection facilities are generally kept at a very high level.

The national person identified health registries kept by EpC include: 
- The Patient Discharge Register

All health care episodes in public and private hospitals since 1987

- The Cancer Register

All malignant primary tumours since 1958

- The Medical Birth Register

Medical data on all births since 1973

- The Cause of Death Register

All deaths since 1952 recorded on data medium, on paper much further back.

- The Prescription Drug Register

All prescription drugs sold as from July 1, 2005.

The parliament decision to create this register was taken on April 27, 2005.

The health data registries are essential for national and international health research and provide the basis for the Swedish health information system. 


\section{Bilag 5.}

\section{Generiske og sygdomsspecifikke kvalitetsindikatorer}

\section{Landsdækkende og regionale kliniske kvalitetsdatabaser, Danmark}

\begin{tabular}{|c|c|c|}
\hline Navn & Dækning & Kontaktperson \\
\hline $\begin{array}{l}\text { Biologisk behandling i dansk dermato- } \\
\text { logi }\end{array}$ & $\begin{array}{l}\text { Lands- } \\
\text { dækkende }\end{array}$ & $\begin{array}{l}\text { Tomas Norman Dam } \\
\text { TNDam@dadlnet.dk }\end{array}$ \\
\hline Cerebral Parese Opfølgnings Program & Regional & $\begin{array}{l}\text { Niels Wisbech Pedersen } \\
\text { niels.w.pedersen@ouh.regions- } \\
\text { yddanmark.dk }\end{array}$ \\
\hline $\begin{array}{l}\text { DANBIO - Dansk Rheumatologisk } \\
\text { Database }\end{array}$ & $\begin{array}{l}\text { Lands- } \\
\text { dækkende }\end{array}$ & $\begin{array}{l}\text { Anette Hansen } \\
\text { ann.han@dadlnet.dk }\end{array}$ \\
\hline $\begin{array}{l}\text { Danish Breast Cancer Cooperative } \\
\text { Group }\end{array}$ & $\begin{array}{l}\text { Lands- } \\
\text { dækkende }\end{array}$ & $\begin{array}{l}\text { Ledende statistiker Susanne Møller } \\
\text { sm@dbcg.dk }\end{array}$ \\
\hline $\begin{array}{l}\text { Dansk AlmenMedicinsk Database for } \\
\text { diabetes }\end{array}$ & $\begin{array}{l}\text { Lands- } \\
\text { dækkende }\end{array}$ & $\begin{array}{l}\text { Speciallæge Henrik Schroll } \\
\text { hschroll@dak-e.dk }\end{array}$ \\
\hline Dansk Anæstesi Database & $\begin{array}{l}\text { Lands- } \\
\text { dækkende }\end{array}$ & $\begin{array}{l}\text { Per Føge Jensen } \\
\text { perje@gen.regionh.dk }\end{array}$ \\
\hline Dansk BlæreCancer Register & $\begin{array}{l}\text { Lands- } \\
\text { dækkende }\end{array}$ & $\begin{array}{l}\text { Gregers G. Hermann } \\
\text { gregers.hermann@frh.regionh.dk }\end{array}$ \\
\hline $\begin{array}{l}\text { Dansk Esophagus-, Cardia- og Ventri- } \\
\text { kel Cancerdatabase }\end{array}$ & $\begin{array}{l}\text { Lands- } \\
\text { dækkende }\end{array}$ & $\begin{array}{l}\text { Lone Susanne Jensen } \\
\text { lonsusje@rm.dk }\end{array}$ \\
\hline Dansk Fedmekirurgiregister & $\begin{array}{l}\text { Lands- } \\
\text { dækkende }\end{array}$ & $\begin{array}{l}\text { Prof.Dr.med. Peter Funch-Jensen } \\
\text { peter.funch@aarhus.rm.dk }\end{array}$ \\
\hline Dansk Galdedatabase & $\begin{array}{l}\text { Lands- } \\
\text { dækkende }\end{array}$ & $\begin{array}{l}\text { Overlæge Linda Bardram } \\
\text { linda.bardram@rh.regionh.dk }\end{array}$ \\
\hline Dansk Gynækologisk Cancer Database & $\begin{array}{l}\text { Lands- } \\
\text { dækkende }\end{array}$ & $\begin{array}{l}\text { Klinisk Forskningslektor Claus Høgdall } \\
\text { claus.hoegdall@rh.regionh.dk }\end{array}$ \\
\hline Dansk Herniedatabase & $\begin{array}{l}\text { Lands- } \\
\text { dækkende }\end{array}$ & $\begin{array}{l}\text { Professor Henrik Kehlet } \\
\text { henrik.kehlet@rh.regionh.dk }\end{array}$ \\
\hline Dansk Hjerteregister & $\begin{array}{l}\text { Lands- } \\
\text { dækkende }\end{array}$ & $\begin{array}{l}\text { Helle Wallach Kildemoes } \\
\text { hwk@niph.dk }\end{array}$ \\
\hline Dansk Hovedtraume Database & & $\begin{array}{l}\text { Jørgen Feldbæk Nielsen } \\
\text { joerniel@rm.dk }\end{array}$ \\
\hline Dansk Hysterektomi Database & $\begin{array}{l}\text { Lands- } \\
\text { dækkende }\end{array}$ & $\begin{array}{l}\text { Centerdirektør Bent Ottesen } \\
\text { bent.ottesen@rh.regionh.dk }\end{array}$ \\
\hline Dansk Intensiv Database & $\begin{array}{l}\text { Lands- } \\
\text { dækkende }\end{array}$ & $\begin{array}{l}\text { Reinhold H. Hansen } \\
\text { r.jensen@dadlnet.dk }\end{array}$ \\
\hline
\end{tabular}




\section{Bilag 6.}

\section{Nasjonale medisinske kvalitetsregistre, Norge}

Det er Helse- og omsorgsdepartementet som nå foretar den endelige godkjenning av medisinske kvalitetsregister (Registrene 1-19). I 2009 forelå det et sett med godkjennelseskriterier. Foreløpig foreligger det 19 register som er blitt godkjent av Helse- og omsorgsdepartementet.

Øvrige registre nedenfor:

Dette er register som tidligere har blitt vurdert som nasjonale/regionale etter vurdering som ble gjort i tilknytning til kvalitetsregisterprosjektet 2005. Disse har tideligere blitt betraktet som nasjonal, både ut fra formål og dekningsgrad.

\begin{tabular}{|c|c|c|}
\hline Register & Dekning & Kontaktperson \\
\hline $\begin{array}{l}\text { 1. Nasjonalt medisinsk } \\
\text { kvalitetsregister for barne- } \\
\text { og ungdomsdiabetes }\end{array}$ & $26 / 26$ barneavdelinger & $\begin{array}{l}\text { Torild Skrivarhaug } \\
\text { torild.skrivarhaug@uus.no }\end{array}$ \\
\hline $\begin{array}{l}\text { 2. Norsk nyfødt medisinsk } \\
\text { kvalitetsregister }\end{array}$ & $\begin{array}{l}\text { Alle sykehus registrerer lokalt. } \\
\text { Samling sentralt } 2009\end{array}$ & $\begin{array}{l}\text { Arild Rønnestad } \\
\text { arild.ronnestad@rikshospitalet.no }\end{array}$ \\
\hline $\begin{array}{l}\text { 3. Cerebralparese registe- } \\
\text { ret }\end{array}$ & Nesten alle sykehus & $\begin{array}{l}\text { Guro Andersen } \\
\text { guro.andersen@siv.no }\end{array}$ \\
\hline 4. Nasjonalt traumeregister & $\begin{array}{l}\text { Ikke i drift nasjonalt. Bare lokalt } \\
\text { Ullevål universitets sykehus }\end{array}$ & $\begin{array}{l}\text { Olav Røise } \\
\text { olav.roise@medisin.uio.no }\end{array}$ \\
\hline $\begin{array}{l}\text { 5. Norsk diabetesregister } \\
\text { for voksne }\end{array}$ & $\begin{array}{l}\text { Bare lokalt Stavanger universi- } \\
\text { tets sykehus }\end{array}$ & $\begin{array}{l}\text { Karianne Fjeld Løvaas } \\
\text { karianne.loevaas@noklus.no }\end{array}$ \\
\hline 6. Norsk intensivregister & $32 / 32$ sykehus & $\begin{array}{l}\text { Hans Flaatten } \\
\text { hans.flaatten@helse-bergen.no }\end{array}$ \\
\hline \multirow[t]{2}{*}{$\begin{array}{l}\text { 7. Leppe-kjeve- } \\
\text { ganespalteregisteret }\end{array}$} & $\begin{array}{l}\text { Ikke i drift nasjonalt. Bare lokalt } \\
\text { Haukeland universitets syke- } \\
\text { hus }\end{array}$ & $\begin{array}{l}\text { Oslo-teamet: } \\
\text { Inger B. Tørdal } \\
\text { inger.beate.tordal@-statped.no }\end{array}$ \\
\hline & & $\begin{array}{l}\text { Bergens-teamet: } \\
\text { Åse Rommetveit Remme } \\
\text { asa.remme@helse-bergen.no } \\
\text { Åse Sivertsen } \\
\text { ase.sivertsen@helse-bergen.no }\end{array}$ \\
\hline \multirow{2}{*}{$\begin{array}{l}\text { 8. Nasjonalt register for } \\
\text { kronisk obstruktiv lunge- } \\
\text { sykdom (REGKOLS) }\end{array}$} & $\begin{array}{l}\text { Ikke i drift nasjonalt. Bare } \\
\text { Helse Vest }\end{array}$ & $\begin{array}{r}\text { Amund Gulsvik } \\
\text { amund.gulsvik@meda.uib.no }\end{array}$ \\
\hline & & $\begin{array}{l}\text { Fortsættes....... } \\
\text { Fortsat...... }\end{array}$ \\
\hline
\end{tabular}




\begin{tabular}{|c|c|c|}
\hline Register & Dekning & Kontaktperson \\
\hline $\begin{array}{l}\text { 9. Norsk hjerteinfarkt- } \\
\text { register }\end{array}$ & $\begin{array}{l}\text { lkke i drift nasjonalt. I drift } \\
\text { lokalt i enkelte sykehus }\end{array}$ & $\begin{array}{l}\text { Stig Arild Slørdahl } \\
\text { stig.slordahl@stolav.no }\end{array}$ \\
\hline 10. Norsk slagregister & $\begin{array}{l}\text { Ikke i drift nasjonalt. Bare lokalt } \\
\text { i Helse Midt-syke-husene }\end{array}$ & $\begin{array}{l}\text { Bent Indredavik } \\
\text { bent.indredavik@stolav.no }\end{array}$ \\
\hline $\begin{array}{l}\text { 11. Nasjonalt kvalitetsregis- } \\
\text { ter for ryggkirurgi }\end{array}$ & 26/42 sykehus & $\begin{array}{l}\text { Andreas Sørlie } \\
\text { andreas.sorlie@unn.no }\end{array}$ \\
\hline $\begin{array}{l}\text { 12. Det nasjonale registeret } \\
\text { for arvelige og medfødte } \\
\text { nevromuskulære sykdom- } \\
\text { mer }\end{array}$ & $8 / 24$ sykehus * & $\begin{array}{l}\text { Inger Tranung } \\
\text { inger.tranung@unn.no }\end{array}$ \\
\hline $\begin{array}{l}\text { 13. Norsk Karkirurgisk } \\
\text { register }\end{array}$ & Nasjonal dekning & $\begin{array}{l}\text { Ola D. Sæther } \\
\text { ola.sether@stolav.no }\end{array}$ \\
\hline $\begin{array}{l}\text { 14. Nasjonalt register for } \\
\text { leddproteser }\end{array}$ & Nasjonal dekning & $\begin{array}{l}\text { Ove Furnes } \\
\text { ove.furnes@haukeland.no }\end{array}$ \\
\hline $\begin{array}{l}\text { 15. Nasjonalt hoftebrudds- } \\
\text { register }\end{array}$ & Nasjonal dekning & $\begin{array}{l}\text { Ove Furnes } \\
\text { ove.furnes@haukeland.no }\end{array}$ \\
\hline $\begin{array}{l}\text { 16. Nasjonalt korsbåndre- } \\
\text { gister }\end{array}$ & Nasjonal dekning & $\begin{array}{l}\text { Ove Furnes } \\
\text { ove.furnes@haukeland.no }\end{array}$ \\
\hline 17. Norsk MS-register & $60-65 \%$ dekningsgrad & $\begin{array}{l}\text { Anne- Britt Rundhovde Skår } \\
\text { anne.skar@helse-bergen.no } \\
\text { Randi Cesilie Haugstad } \\
\text { randi.haugstad@-helse-bergen.no }\end{array}$ \\
\hline $\begin{array}{l}\text { 18. Nasjonalt register for } \\
\text { tykk- og endetarmskreft }\end{array}$ & $\begin{array}{l}\text { Nasjonal } \\
\text { dekning }\end{array}$ & $\begin{array}{l}\text { Jan F. Nygård } \\
\text { jan.nygard@-kreftregisteret.no }\end{array}$ \\
\hline $\begin{array}{l}\text { 19. Nasjonalt register for } \\
\text { prostatakreft }\end{array}$ & $\begin{array}{l}\text { Nasjonal } \\
\text { dekning }\end{array}$ & $\begin{array}{l}\text { Jan F. Nygård } \\
\text { jan.nygard@-kreftregisteret.no }\end{array}$ \\
\hline $\begin{array}{l}\text { Kvalitetsregister for selek- } \\
\text { sjon og oppfølging av } \\
\text { epilepsikirurgi }\end{array}$ & Ukjent dekningsgrad & $\begin{array}{l}\text { Geir Ketil Røste } \\
\text { Geir.ketil.roste@-rikshospitalet.no }\end{array}$ \\
\hline Gastronett & Ukjent dekningsgrad & $\begin{array}{l}\text { Geir Hoff } \\
\text { hofg@online.no }\end{array}$ \\
\hline $\begin{array}{l}\text { Gynekologisk laparaskopi- } \\
\text { register }\end{array}$ & $20 \%$ dekningsgrad & $\begin{array}{l}\text { Knut Urdal } \\
\text { Knut.urdal@siv.no }\end{array}$ \\
\hline Register for Hjertekirurgi & Ukjent dekningsgrad & \\
\hline $\begin{array}{l}\text { Nasjonalt register for } \\
\text { hjertestans utenfor sykehus }\end{array}$ & Ukjent dekningsgrad & $\begin{array}{l}\text { Lars Wik } \\
\text { Lars.wik@uus.no }\end{array}$ \\
\hline $\begin{array}{l}\text { Immunhematologisk } \\
\text { prosedyrer }\end{array}$ & Ukjent dekningsgrad & $\begin{array}{l}\text { Hans Erik Heier } \\
\text { hahs@uus.no }\end{array}$ \\
\hline
\end{tabular}




\begin{tabular}{|c|c|c|}
\hline Register & Dekning & Kontaktperson \\
\hline $\begin{array}{l}\text { Kornearegisteret, Ullevål } \\
\text { universitetssykehus }\end{array}$ & Ukjent dekningsgrad & $\begin{array}{l}\text { Bente Haughom } \\
\text { Bente.Haughom@-medisin.uio.no }\end{array}$ \\
\hline Nefrologiregisteret & 99\% dekning & $\begin{array}{l}\text { Torbjørn Leivestad } \\
\text { Torbjorn.leivstad@-rikshospitalet.no }\end{array}$ \\
\hline $\begin{array}{l}\text { Nordic Solid Tumours in } \\
\text { children(NOPHO) }\end{array}$ & Nasjonal dekning & $\begin{array}{l}\text { Jan F. Nygård } \\
\text { Jan.nygard@kreftregisteret.no }\end{array}$ \\
\hline Nyrebiopsiregisteret & $95 \%$ dekningsgrad & $\begin{array}{l}\text { Barne M. Iversen } \\
\text { Bjarne.iversen@-med.uib.no }\end{array}$ \\
\hline $\begin{array}{l}\text { Organspesifikke autoim- } \\
\text { mune sykdommer }\end{array}$ & Ukjent dekningsgrad & $\begin{array}{l}\text { Eystein Husebye } \\
\text { Eystein.husebye@-helse-bergen.no }\end{array}$ \\
\hline $\begin{array}{l}\text { Ovarialcancerregis- } \\
\text { teret(OVANOR) }\end{array}$ & Nasjonal dekning & $\begin{array}{l}\text { Jan F. Nygård } \\
\text { Jan.nygard@kreftregisteret.no }\end{array}$ \\
\hline Porfyriregister & $70 \%$ dekningsgrad & $\begin{array}{l}\text { Sverre Sandberg } \\
\text { Sverre.sandberg@helse-bergen.no }\end{array}$ \\
\hline
\end{tabular}

\section{Bilag 7.}

\section{Mun- och tandhälsovården}

\begin{tabular}{ll}
\hline Övriga deltagere & \\
\hline Mika Gissler & (mika.gissler@thl.fi), \\
Sari Helminen & (sari.helminen@kela.fi), \\
Hanna-Leena Tefke & (hanna-leena.tefke@valvira.fi), \\
Seija Hiekkanen & (seija.hiekkanen@hel.fi), \\
Minna Kinnarinen & (minna.kinnarinen@korsholm.fi) och \\
Maria Waltari & (maria.waltari@stm.fi) har ingåtti den finländska förberedande arbetsgruppen. \\
\hline
\end{tabular}

Experter, t.ex. Jan Mainz (Nordisk Ministerråds styregruppe for kvalitetsmålingsprojekter i sundhedsvæsenet) (jan.mainz@rn.dk), har deltagit i några projektmöten.

Även Jon Dahl (jed@niom.no) från NIOM (Nordiska institutet för odontologiska material), Frank Senderovitz (FRSE@gh.gl) från Grönland och Klas Silfverberg (klas.silfverberg@ahs.ax) från Åland har deltagit i några av projektmötena. 


\section{Bilag 8.}

Tabel 5. NORPEQ på norsk inkludert bakgrunnsspørsmål.

\section{Undersøkelse om pasienters erfaringer fra sykehusopphold}

Hensikten med denne undersøkelsen:

Vi ønsker å vite mer om hvordan patienter har det når de er innlagt på sykehus. Det endelige målet er å forbedre kvaliteten på tilbudet ved norske sykehus. Dine erfaringer er viktige for oss og vi håper de vil bruke noen minutter på å fylde ut spørreskemaet.

Om utfyllingen: Vi ønsker din umiddelbare vurdering. Husk at alle svaralternativene kan benyttes, men sett kun ett kryss på hvert spørsmål.

\section{Erfaringer fra sykehusoppholdet}

\begin{tabular}{|c|c|c|c|c|c|}
\hline I hvilken grad... & $\begin{array}{l}\text { Ikke i det } \\
\text { hele tatt }\end{array}$ & I liten grad & $\begin{array}{l}\text { I noen } \\
\text { grad }\end{array}$ & I stor grad & $\begin{array}{l}\text { I svart stor } \\
\text { grad }\end{array}$ \\
\hline \multicolumn{6}{|l|}{$\begin{array}{l}\text { 1. snakket legene til deg slik } \\
\text { at du forsto dem? }\end{array}$} \\
\hline \multicolumn{6}{|l|}{$\begin{array}{l}\text { 2. har du tillit til legenes } \\
\text { faglige dyktighet? }\end{array}$} \\
\hline \multicolumn{6}{|l|}{$\begin{array}{l}\text { 3. har du tillit til pleiepersona- } \\
\text { lets faglige dyktighet? }\end{array}$} \\
\hline \multicolumn{6}{|l|}{$\begin{array}{l}\text { 4. opplevde du at pleieperso- } \\
\text { nalet hadde omsorg for deg? }\end{array}$} \\
\hline \multicolumn{6}{|l|}{$\begin{array}{l}\text { 5. opplevde du at legene og } \\
\text { pleiepersonaet var interessert } \\
\text { i din beskrivelse av egen } \\
\text { situasjon? }\end{array}$} \\
\hline \multicolumn{6}{|l|}{$\begin{array}{l}\text { 6. fikk du vite det du syntes } \\
\text { var nødvendig om hvordan } \\
\text { prøver og undersøkelser } \\
\text { skulle foregå? }\end{array}$} \\
\hline \multicolumn{6}{|l|}{$\begin{array}{l}\text { 7. var pleien og behandlingen } \\
\text { du fikk på sykehuset, alt i alt, } \\
\text { tilfredsstillende? }\end{array}$} \\
\hline \multicolumn{6}{|l|}{$\begin{array}{l}\text { 8. mener du at du på noen } \\
\text { måte ble feilbehandlet (etter } \\
\text { det du selv kan bedømma)? }\end{array}$} \\
\hline & $\begin{array}{l}\text { Mye } \\
\text { dårligere } \\
\text { enn } \\
\text { forventet }\end{array}$ & $\begin{array}{l}\text { Noe } \\
\text { dårligere } \\
\text { enn } \\
\text { forventet }\end{array}$ & $\begin{array}{l}\text { Som } \\
\text { forventet }\end{array}$ & $\begin{array}{l}\text { Litt bedre } \\
\text { enn } \\
\text { forventet }\end{array}$ & $\begin{array}{l}\text { Mye bedre } \\
\text { enn } \\
\text { forventet }\end{array}$ \\
\hline \multicolumn{6}{|l|}{$\begin{array}{l}\text { 9. Er dine erfaringer med } \\
\text { pleien og behandlingen på } \\
\text { sykehuset dårligere enn } \\
\text { forventet? }\end{array}$} \\
\hline $\begin{array}{l}\text { 10. Har sykehuset gjort din } \\
\text { helsetilstand dårligere enn } \\
\text { forventet, som forventet eller } \\
\text { bedre enn forventet? }\end{array}$ & & & & & \\
\hline
\end{tabular}




\section{Bakgrunnsopplysninger}

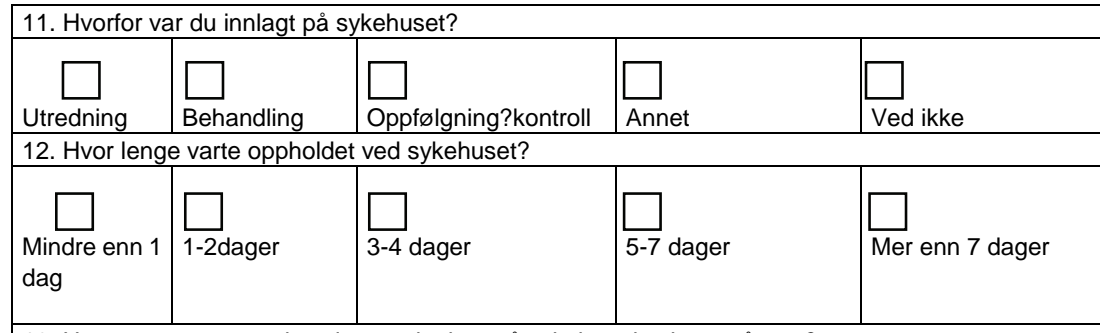

13. Hvor mange ganger har du vært innlagt på sykehus de siste to årene?

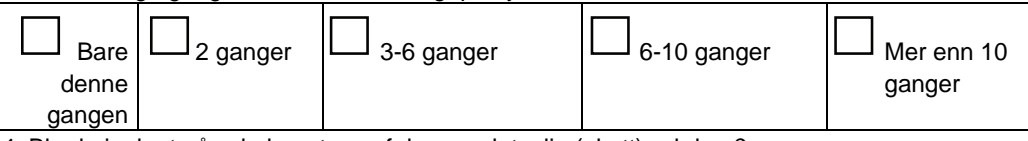

14. Ble du innlagt på sykehuset som følge av plutselig (akutt) sykdom?

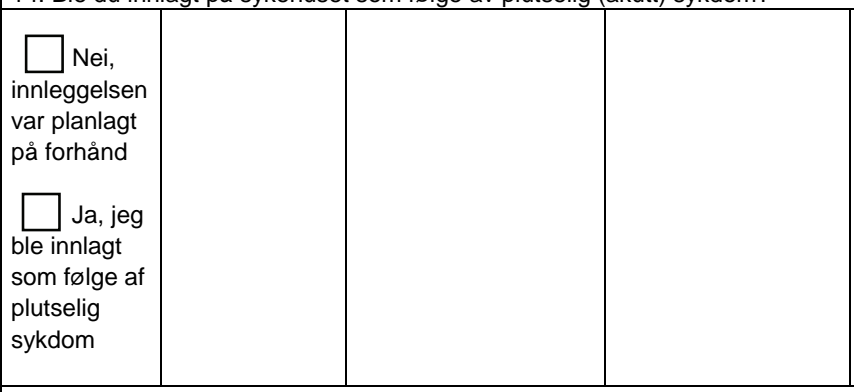

15. Stort sett, vil du si at din helse er ...

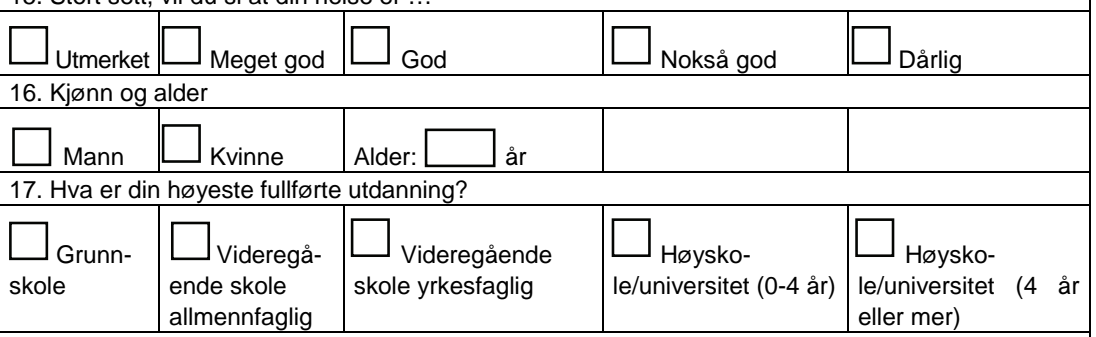

18. Hva gjør du til daglig (sett kun ett kryss)?

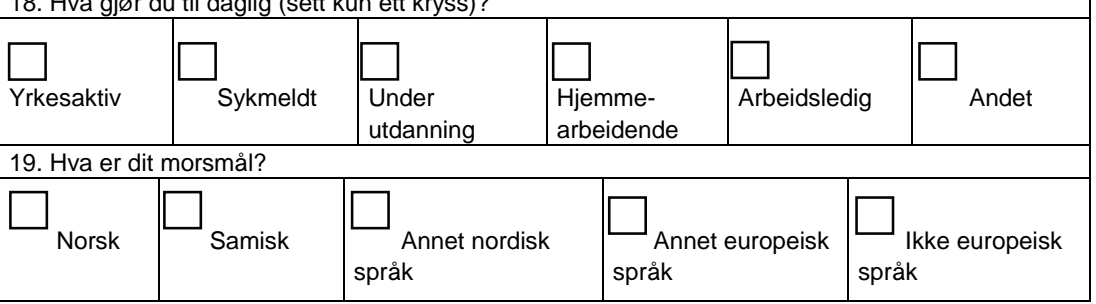




\section{Bilag 9.}

Tabell 5. NORPEQ på dansk

\begin{tabular}{|c|c|c|c|c|c|}
\hline I hvilken grad... & Slet ikke & $\begin{array}{l}\text { I mindre } \\
\text { grad }\end{array}$ & $\begin{array}{l}\text { I nogen } \\
\text { grad }\end{array}$ & $\begin{array}{l}\text { I høj } \\
\text { grad }\end{array}$ & $\begin{array}{l}\text { I meget } \\
\text { høj grad }\end{array}$ \\
\hline $\begin{array}{l}\text { 1. Talte lægerne med dig på en måde, } \\
\text { at du forstod dem? }\end{array}$ & & & & & \\
\hline $\begin{array}{l}\text { 2. Har du tillid til lægernes faglige } \\
\text { dygtighed? }\end{array}$ & & & & & \\
\hline $\begin{array}{l}\text { 3. Har du tillid til plejepersonalets } \\
\text { faglige dygtighed? }\end{array}$ & & & & & \\
\hline $\begin{array}{l}\text { 4. Oplevede du, at plejepersonalet } \\
\text { viste omsorg for dig? }\end{array}$ & & & & & \\
\hline $\begin{array}{l}\text { 5. Oplevede du, at lægerne og } \\
\text { plejepersonalet var interesserede i } \\
\text { din beskrivelse af din egen situation? }\end{array}$ & & & & & \\
\hline $\begin{array}{l}\text { 6. Synes du, at du fik den nødvendi- } \\
\text { ge viden om, hvordan prøver og } \\
\text { undersøgelser skulle foregå? }\end{array}$ & & & & & \\
\hline $\begin{array}{l}\text { 7. Var plejen og behandlingen, du } \\
\text { modtog på sygehuset, alt i alt } \\
\text { tilfredstillende? }\end{array}$ & & & & & \\
\hline $\begin{array}{l}\text { 8. Mener du, at du på nogen måde } \\
\text { blev fejlbehandlet? (ud fra hvad du } \\
\text { selv kan bedømme) }\end{array}$ & & & & & \\
\hline
\end{tabular}




\section{Bilag 10.}

Tabell 7. NORPEQ på finsk

\begin{tabular}{|c|c|c|c|c|c|}
\hline Missä määrin... & $\begin{array}{l}\text { Ei } \\
\text { lainkaan }\end{array}$ & $\begin{array}{l}\text { Vähäi- } \\
\text { sessä } \\
\text { määrin }\end{array}$ & $\begin{array}{l}\text { Jossain } \\
\text { määrin }\end{array}$ & $\begin{array}{l}\text { Suures- } \\
\text { sa } \\
\text { määrin }\end{array}$ & $\begin{array}{l}\text { Erittäin } \\
\text { suuressa } \\
\text { määrin }\end{array}$ \\
\hline $\begin{array}{l}\text { 1. Lääkärit puhuivat sinulle ymmärret- } \\
\text { tävästi? }\end{array}$ & & & & & \\
\hline $\begin{array}{l}\text { 2. Luotat lääkäreiden ammattitaito- } \\
\text { on? }\end{array}$ & & & & & \\
\hline 3. Luotat hoitajien ammattitaitoon? & & & & & \\
\hline $\begin{array}{l}\text { 4. Koit, että lääkärit ja hoitajat olivat } \\
\text { kiinnostuneita siitä mitä itse kerroit } \\
\text { tilanteestasi? }\end{array}$ & & & & & \\
\hline $\begin{array}{l}\text { 5. Sait kaiken mielestäsi tarpeellisen } \\
\text { tiedon kokeiden ja tutkimusten } \\
\text { etenemisestä? }\end{array}$ & & & & & \\
\hline $\begin{array}{l}\text { 6. Sait kaiken mielestäsi tarpeellisen } \\
\text { tiedon kokeiden ja tutkimusten } \\
\text { etenemisestä? }\end{array}$ & & & & & \\
\hline $\begin{array}{l}\text { 7. Olet kaiken kaikkiaan tyytyväinen } \\
\text { saamaasi hoitoon ja hoivaan? }\end{array}$ & & & & & \\
\hline $\begin{array}{l}\text { 8. Sinua mielestäsi hoidettiin jollakin } \\
\text { tavalla virheellisesti (oman arviosi } \\
\text { mukaan)? }\end{array}$ & & & & & \\
\hline
\end{tabular}




\section{Bilag 11.}

Tabell 8. NORPEQ på færøysk

\begin{tabular}{|c|c|c|c|c|c|}
\hline $\begin{array}{l}\text { 1. Í hvønn mun tosaðu læknarnir } \\
\text { við teg á ein slíkan hátt, at tú skilti } \\
\text { teir? }\end{array}$ & Als ikki & $\begin{array}{l}\text { Í minni } \\
\text { mum }\end{array}$ & $\begin{array}{l}\text { Í ávísan } \\
\text { mun }\end{array}$ & $\begin{array}{l}\text { Í stóran } \\
\text { mun }\end{array}$ & $\begin{array}{l}\text { Í sera } \\
\text { stóran mun }\end{array}$ \\
\hline $\begin{array}{l}\text { 2. Í hvønn mun hevur tú állt á } \\
\text { fakliga dugnaskapin hjá røktars- } \\
\text { tarvsfólkunum? }\end{array}$ & Als ikki & $\begin{array}{l}\text { Í minni } \\
\text { mum }\end{array}$ & $\begin{array}{l}\text { Í ávísan } \\
\text { mun }\end{array}$ & $\begin{array}{l}\text { Í stóran } \\
\text { mun }\end{array}$ & $\begin{array}{l}\text { Í sera } \\
\text { stóran mun }\end{array}$ \\
\hline $\begin{array}{l}\text { 3. Í hvønn mun hevur tú állt á } \\
\text { fakliga dugnaskapin hjá røktar- } \\
\text { starvsfólkunum? }\end{array}$ & Als ikki & $\begin{array}{l}\text { Í minni } \\
\text { mum }\end{array}$ & $\begin{array}{l}\text { Í ávísan } \\
\text { mun }\end{array}$ & $\begin{array}{l}\text { Í stóran } \\
\text { mun }\end{array}$ & $\begin{array}{l}\text { Í sera } \\
\text { stóran } \\
\text { mu }\end{array}$ \\
\hline $\begin{array}{l}\text { 4. Í hvønn mun upplivdi tú, at } \\
\text { læknarnir og røktarstarvsfólkini } \\
\text { vistu umsorgan fyri tær? }\end{array}$ & Als ikki & $\begin{array}{l}\text { Í minni } \\
\text { mum }\end{array}$ & Í ávísan & $\begin{array}{l}\text { Í stóran } \\
\text { mun }\end{array}$ & $\begin{array}{l}\text { Í sera } \\
\text { stóran } \\
\text { mu }\end{array}$ \\
\hline $\begin{array}{l}\text { 5. Í hvønn mun upplivdi tú. at } \\
\text { læknarnir og røktarstarvsfólkini } \\
\text { vóru áhugað í tíni frágreiðing av } \\
\text { tínari egnu støðu? }\end{array}$ & Als ikki & $\begin{array}{l}\text { Í minni } \\
\text { mum }\end{array}$ & $\begin{array}{l}\text { Í ávísan } \\
\text { mun }\end{array}$ & $\begin{array}{l}\text { Í stóran } \\
\text { mun }\end{array}$ & $\begin{array}{l}\text { Í sera } \\
\text { stóran } \\
\text { mun }\end{array}$ \\
\hline $\begin{array}{l}\text { 6. Í hvønn mun heldur tú, tú fekk } \\
\text { ta neyðugu kunningina um, } \\
\text { hvussu royndir og kanningar } \\
\text { skuldu gerast? }\end{array}$ & Als ikki & $\begin{array}{l}\text { Î minni } \\
\text { mum }\end{array}$ & $\begin{array}{l}\text { Í ávísan } \\
\text { mun }\end{array}$ & $\begin{array}{l}\text { Í stóran } \\
\text { mun }\end{array}$ & $\begin{array}{l}\text { Í sera } \\
\text { stóran } \\
\text { mun }\end{array}$ \\
\hline $\begin{array}{l}\text { 7. Í hvønn mun vóru røktin og } \\
\text { viðgerðin, tú fekk á sjúkrahús- } \\
\text { inum samanumtiklð nøktandi? }\end{array}$ & Als ikki & $\begin{array}{l}\text { Î́ minni } \\
\text { mum }\end{array}$ & $\begin{array}{l}\text { Í ávísan } \\
\text { mun }\end{array}$ & $\begin{array}{l}\text { Í stóran } \\
\text { mun }\end{array}$ & $\begin{array}{l}\text { Í sera } \\
\text { stóran } \\
\text { mun }\end{array}$ \\
\hline $\begin{array}{l}\text { 8. í hvønn mun heldur tú, at tað } \\
\text { á nakran hátt, vórðu framd } \\
\text { mistøk í tí viðgerð tú fekst? }\end{array}$ & Als ikki & $\begin{array}{l}\text { Î minni } \\
\text { mum }\end{array}$ & $\begin{array}{l}\text { Í ávísan } \\
\text { mun }\end{array}$ & $\begin{array}{l}\text { Í stóran } \\
\text { mun }\end{array}$ & $\begin{array}{l}\text { Í sera } \\
\text { stóran } \\
\text { mun }\end{array}$ \\
\hline
\end{tabular}




\section{Bilag 12.}

\section{Tabell 9. NORPEQ på islandsk}

\section{Reynsla af sjúkrahúsdcöl á}

Fyrir nokkru varst Pú lögð (lagður) inn ä sjúkrahúsið. pess vegna langar okkur að biðja pig að gefa per tíma til að̃ svara neðangreindum spurningum. Niðursttöðumar hjálpa okkur sem vinnum par að bæta pjónustu okkar enn frekar. Öll svör hjálpa okkur hvort sem reynsla Pín hefur verið jákvæð eða meikvæð. Vinsamlega settu x í einn af reitunum við̆ hverja spurningu, gjarnan við pað svar sem kemur fyrst upp í hugann.

Revnsla bín

\begin{tabular}{|c|c|c|c|c|c|}
\hline Að hve miklu leyti: & Alls akki & $\begin{array}{l}\text { Að litlu } \\
\text { leyti }\end{array}$ & Nokkuð & $\begin{array}{l}\text { Að̃ miklu } \\
\text { leyti }\end{array}$ & Alveg \\
\hline $\begin{array}{l}\text { 1. Töluðu læknarnir við pig Pannig } \\
\text { að pú skildir pá? }\end{array}$ & & & & & \\
\hline $\begin{array}{l}\text { 2. Treystir Pú faglegri hæfni læknan- } \\
\text { na? }\end{array}$ & & & & & \\
\hline $\begin{array}{l}\text { 3. Treystir Pú faglegri hæfni hjúkru- } \\
\text { narfræðinganna/slúkraliðanna? }\end{array}$ & & & & & \\
\hline $\begin{array}{l}\text { 4. Fannst Pér hjúkrunarfræðingarnir- } \\
\text { /sjúkraliðarnir bera umhyggju fyrir } \\
\text { Dér? }\end{array}$ & & & & & \\
\hline $\begin{array}{l}\text { 5. Fannst Pér hjúkrunarfræðingarnir- } \\
\text { /sjúkraliðarnir hafa áhuga á Pví hver- } \\
\text { nig Pú lýstir ástandi Pínu? }\end{array}$ & & & & & \\
\hline $\begin{array}{l}\text { 6. Fékkst Pú að vita Pað sem Pú taldir } \\
\text { nauðsynlegt um hvernig sýnatökum } \\
\text { og rannsóknum yrði háttað? }\end{array}$ & & & & & \\
\hline $\begin{array}{l}\text { 7. Var umönnun og meðferð Pín á } \\
\text { sjúkrahúsinu á heildina litið fullnæg- } \\
\text { jandi? }\end{array}$ & & & & & \\
\hline $\begin{array}{l}\text { 8. Telur Pü að Pü hafir á einhvern hátt } \\
\text { fengið ranga meðhöndlun (eftir Pví } \\
\text { sem Pú getur dæmt sjálf/ur)? }\end{array}$ & & & & & \\
\hline
\end{tabular}




\section{Bilag 13.}

Tabell 10. NORPEQ på svensk

\begin{tabular}{|c|c|c|c|c|c|}
\hline I vilken omfattning & Inte alls & $\begin{array}{l}\text { I liten } \\
\text { grad }\end{array}$ & $\begin{array}{l}\text { I någon } \\
\text { grad }\end{array}$ & $\begin{array}{l}\text { I hög } \\
\text { grad }\end{array}$ & $\begin{array}{l}\text { I mycket } \\
\text { hög grad }\end{array}$ \\
\hline $\begin{array}{l}\text { 1. Pratade läkarna med dig så du } \\
\text { förstod vad de sa? }\end{array}$ & & & & & \\
\hline $\begin{array}{l}\text { 2. Har du förtroende för läkarnas } \\
\text { yrkeskunskap? }\end{array}$ & & & & & \\
\hline $\begin{array}{l}\text { 3. Har du förtroende för sköterskor- } \\
\text { nas yrkeskunskap? }\end{array}$ & & & & & \\
\hline $\begin{array}{l}\text { 4.Upplevde du att sköterskorna tog } \\
\text { väl hand om dig? }\end{array}$ & & & & & \\
\hline $\begin{array}{l}\text { 5. Upplevde du att läkarna och skö- } \\
\text { terskorna var intresserade när du } \\
\text { beskrev din egen situation? }\end{array}$ & & & & & \\
\hline $\begin{array}{l}\text { 6. Fick du tillräcklig information om } \\
\text { hur provtagningar och undersök- } \\
\text { ningar skulle gå till? }\end{array}$ & & & & & \\
\hline $\begin{array}{l}\text { 7. Var omvårdnaden och behand- } \\
\text { lingen du fick på sjukhuset totalt sett } \\
\text { tillfredsställande? }\end{array}$ & & & & & \\
\hline $\begin{array}{l}\text { 8. Anser du att du på något sätt blev } \\
\text { felbehandlad (utifrån det du själv kan } \\
\text { bedömma)? }\end{array}$ & & & & & \\
\hline
\end{tabular}




\section{Bilag 14}

\section{- Medlemmarna i projektgruppen och i expertgrupperna}

Medlemmarna i projektgruppen och expertgrupperna för framtagning av patientsäkerhetsindikatorer

\section{Projektgruppen}

Danmark

- Paul Bartels, Cheflæge, Leder af Det Nationale Indikatorprojekt, OECD-representant, paubar@rm.dk

\section{Finland}

- Päivi Hämäläinen, Direktör, Departement för information, Institutet för hälsa och välfärd, OECD- representant, paivi.hamalainen@thl.fi

Färöarna

- Turid Arge, Afdelingschef, Sundhedsministeriet, turid.arge@hmr.fo

Grönland

Turid Bjarnason Skifte, Sygeplejerske MPH, Landslægeembedet i Grønland, tbs@nanoq.gl

Island

- Laura Sch. Thorsteinsson, Projektledare, Medicinaldirektoratet i Island, laura@landlaeknir.is

Norge

- Målfrid Monge, Seniorrådgiver, Helsedirektoratet, mmo@helsedir.no Øystein Flesland, Seksjonsleder, seksjon for meldesystemer, Nasjonalt kunnskapssenter for helsetjenesten,

Oystein.flesland@kunnskapssenteret.no 
Sverige

- Michael Soop, (Projektledare), Medicinalråd, Docent, Socialstyrelsen, OECD-representant, michael.soop@socialstyrelsen.se

- Eva Estling, Samordnare för patientsäkerhet, Sveriges Kommuner och Landsting, eva.estling@skl.se

- Hans Rutberg, (Sekreterare i projektgruppen), Chefläkare, Docent, Universitetssjukhuset i Linköping, hans.rutberg@lio.se

\section{Expertgrupperna:}

Vårdskador i sluten somatisk vård

Hans Rutberg (Ordförande), Chefläkare, Docent, Universitetssjukhuset i Linköping, hans.rutberg@lio.se

Leifur Barðason, Overlæge, Avdeling for kvalitetsudvikling, Landspitali, leifurba@landspitali.is

Urban Jürgensen, Överläkare, Qulturum, Landstinget i Jönköping, urban.jurgensen@lj.se

Line Riis Jølving, Sundhedsfaglig proceskonsulent, Cand. scient. san., Det Nationale Indikatorprojekt NIP - sekretariatet, line.joelving@stab.rm.dk

Helge Svaar, Pasientsikkerhetssjef, Akershus universitetssykehus, helge.svaar@ahus.no

Laura Sch. Thorsteinsson, Projektledare, Medicinaldirektoratet i Island, laura@landlaeknir.is

Juha Öhman Professor, Överläkare, Tammerfors universitetssjukhus, juha.ohman@pshp.fi 


\section{Patientsäkerhetskultur}

Paul Bartels (Ordförande), Cheflæge, Leder af Det Nationale Indikatorprojekt, OECD- representant, paubar@rm.dk

Marlene Dyrløv Madsen, Ph.d., Forsker, Dansk Institut for Medicinsk Simulation, Herlev Hospital, Region Hovedstaden, madyma01@heh.regionh.dk

Dag Hofoss, Professor, dr philos, Institutt for helse og samfunn, Universitetet i Oslo, Institutt for samfunnsmedisin, Universitetet i Tromsø, dag.hofoss@medisin.uio.no

Pia Maria Jonsson, Med.dr., Utvecklingschef, Institutet för hälsa och välfärd (THL), Enheten för utveckling av social- och hälsotjänster, pia.maria.jonsson@thl.fi

Solvejg Kristensen, MHSc, Chefkonsulent, Enhed for Klinsk Kvalitet og Patientsikkerhed, Region Midtjylland, solkri@rm.dk

Jessica Lindberg, Medicinsk sakkunnig i kvalitet och patientsäkerhet, Stockholms Läns Landsting, jessica.lindberg@sll.se

Marion Lindh, Chefläkare, Sakkunnig i kvalitets- och patientsäkerhetsfrågor, Produktionssamordning - Övergripande vårdfrågor, Landstingstyrelsens förvaltning, marion.lindh@sll.se

Laura Sch. Thorsteinsson, Projektledare, Medicinaldirektoratet i Island, laura@landlaeknir.is

Peter Skjøt, Risikomanager, MI Region Hovedstadens Enhed for Patientsikkerhed, peter.skjoet@regionh.dk

Ellen Tveter Deilkås, MD, PhD, Overlege, Akershus Universitetssykehus, Seniorrådgiver, Nasjonal enhet for pasientsikkerhet, Nasjonalt Kunnskapssenter for helsetjenesten, eld@kunnskapssenteret.no 


\section{Sjukhusmortalitet}

Paul Bartels,(Ordförande), Cheflæge, Leder af Det Nationale Indikatorprojekt, OECD- representant, paubar@rm.dk

Leifur Barðason, Overlæge, Avdeling for kvalitetsudvikling, Landspitali, leifurba@landspitali.is

Jon Helgeland, Seksjonsleder, Nasjonalt kunnskapssenter for helsetjenesten, Jon.Helgeland@kunnskapssenteret.no

Päivi Hämäläinen, Direktör, Departement för information, Institutet för hälsa och välfärd, OECD- representant, paivi.hamalainen@thl.fi Max Köster, Sakkunnig, Enheten för befolkningsstatistik, Socialstyrelsen, max.koster@socialstyrelsen.se

Gunnar Ljunggren, Medicinsk rådgivare, Överläkare, Enheten för Analyser \& Jämförelser Medicinskt Kunskapscentrum Stockholms Läns Landsting, gunnar.ljunggren@sll.se

Mette Nørgaard, Overlæge, PhD, Lektor, Klinisk Epidemiologisk Afdeling, Aarhus Universitetshospital, m.noergaard@rn.dk

Hans Rutberg, Chefläkare, Docent, Universitetssjukhuset i Linköping, hans.rutberg@lio.se

\section{Vårdrelaterade infektioner}

Egil Lingaas, (Ordförande), Avdelingssjef, Avdeling for sykehushygiene, Oslo universitetssykehus HF, Rikshospitalet egil.lingaas@oslouniversitetssykehus.no

Hanne-Merete Eriksen, Seniorrådgiver, Nasjonalt folkehelseinstitutt, hmer@fhi.no

Mats Erntell, Smittskyddsläkare, Länssjukhuset Halmstad, mats.erntell@lthalland.se 
Olafur Gudlaugsson, Director infection control, hospital epidemiologist, olafgudl@landspitali.is

Bjørn G. Iversen, Overlege, Folkehelseinstituttet, bjorn.iversen@fhi.no

Jens Kjølseth Møller, Forskningsoverlege, Klinisk Mikrobiologisk Afdeling, Århus Universitetshospital, jensmoel@rm.dk

Outi Lyytikäinen, Smittskyddsläkare, Departement för infektioner, Institutet för hälsa och välfärd, outi.lyytikainen@thl.fi

Hans Rutberg, Chefläkare, Docent, Universitetssjukhuset i Linköping, hans.rutberg@lio.se

Sonia Wallin, Sveriges Kommuner och Landsting, sonia.wallin@skl.se

Överförskrivning av läkemedel hos äldre

Päivi Hämäläinen (Ordförande), Direktör, Departement för information, Institutet för hälsa och välfärd, OECD representant, paivi.hamalainen@thl.fi

Turid Bjarnason Skifte, Sygeplejerske MPH, Landslægeembedet i Grønland, tbs@nanoq.gl

Just Ebbesen, Administrerende direktør, Sykehuset Østfold, postmottak@so-hf.no

Johan Fastbom, Docent, Läkare, Socialstyrelsen, johan.fastbom@socialstyrelsen.se

Øystein Flesland, Seksjonsleder, seksjon for meldesystemer, Nasjonalt kunnskapssenter for helsetjenesten, oystein.flesland@kunnskapssenteret.no

Matthías Halldórsson, Specialist läkare, Medicinaldirektoratet i Island, mattha@landlaeknir.is 
Annemarie Hellebeck, Overlæge, Risikomanager Hvidovre Hospital og Konsulent på medicineringsområdet, Dansk Selskab for Patientsikkerhed Hvidovre Hospital, annemarie.hellebek@hvh.regionh.dk

Pia Maria Jonsson, Med.dr., Utvecklingschef, Institutet för hälsa och välfärd (THL), Enheten för utveckling av social- och hälsotjänster, pia.maria.jonsson@thl.fi

Marianne Lisby, Kvalitetskonsulent, Afdeling for Kvalitetsudvikling og Patientsikkerhed, Århus Universitetshospital, Århus Sygehus, lisby@as.aaa.dk

Taina Mäntyranta, Medicinalråd, Social- och hälsovårdsministeriet, Finland, taina.mantyranta@stm.fi

Sari Palojoki, Utvecklingschef, Institutet för hälsa och välfärd (THL), Departement för information, sari.palojoki@thl.fi

Pirjo Pennanen, Medicinalråd, Tillstånds- och tillsynsverket för socialoch hälsovården (Valvira), Finland, pirjo.pennanen@valvira.fi 